Florida International University

FIU Digital Commons

FIU Electronic Theses and Dissertations

University Graduate School

$11-10-2020$

\title{
Connections in the Underworld: A Morphological and Molecular Study of Diversity and Connectivity among Anchialine Shrimp.
}

Robert Eugene Ditter

Florida International University, rditt003@fiu.edu

Follow this and additional works at: https://digitalcommons.fiu.edu/etd

Part of the Biodiversity Commons, Bioinformatics Commons, Biology Commons, Ecology and

Evolutionary Biology Commons, Genetics and Genomics Commons, Marine Biology Commons, Natural

Resources and Conservation Commons, Oceanography Commons, Other Environmental Sciences

Commons, Speleology Commons, and the Zoology Commons

\section{Recommended Citation}

Ditter, Robert Eugene, "Connections in the Underworld: A Morphological and Molecular Study of Diversity and Connectivity among Anchialine Shrimp." (2020). FIU Electronic Theses and Dissertations. 4561. https://digitalcommons.fiu.edu/etd/4561

This work is brought to you for free and open access by the University Graduate School at FIU Digital Commons. It has been accepted for inclusion in FIU Electronic Theses and Dissertations by an authorized administrator of FIU Digital Commons. For more information, please contact dcc@fiu.edu. 


\section{FLORIDA INTERNATIONAL UNIVERSITY}

Miami, Florida

\section{CONNECTIONS IN THE UNDERWORLD: A MORPHOLOGICAL AND MOLECULAR STUDY OF DIVERSITY AND CONNECTIVITY AMONG ANCHIALINE SHRIMP}

A dissertation submitted in partial fulfillment of the requirements for the degree of DOCTOR OF PHILOSOPHY

in

BIOLOGY

by

Robert E. Ditter 
To: Dean Michael R. Heithaus

College of Arts, Sciences and Education

This dissertation, written by Robert E. Ditter, and entitled Connections in the Underworld: A Morphological and Molecular Study of Diversity and Connectivity among Anchialine Shrimp, having been approved in respect to style and intellectual content, is referred to you for judgment.

We have read this dissertation and recommend that it be approved.

Jose M. Eirin-Lopez

Jessica U. Liberles

Demian Chapman

Dean Whitman

Eric S. Cole

Heather D. Bracken-Grissom, Major Professor

Date of Defense: November 10, 2020

The dissertation of Robert E. Ditter is approved.

Dean Michael R. Heithaus
College of Arts, Sciences and Education

College of Arts, Sciences and Education

Andrés G. Gil

Vice President for Research and Economic Development and Dean of the University Graduate School

Florida International University, 2020 
(C) Copyright 2020 by Robert E. Ditter

All rights reserved. 


\section{DEDICATION}

This dissertation is dedicated Peggy Sue Wayne who gave me courage and motivation to always follow my dreams, no matter how silly it may seem or what other people think. I would also like to dedicate this dissertation to Matt Inman and Jibbers Crabst who gave me the inspiration to tough it out and finish, even during times of crisis. Last, but not least I would like to dedicate this to all my teachers, my parents, everyone whose has shed blood that made this all possible and Ms. Aubree Zenone. Without their support, none of this would have been possible. 


\section{ACKNOWLEDGMENTS}

My dissertation is the product of started as a simple undergraduate research project that blossomed into the what it is today. None of this would be possible without the immeasurable help that I received along the way. My major professor/advisor/life coach, Dr. Heather Bracken-Grissom, who taught me, all about the various facets of real science, provided me with just the right motivation and support to keep me moving forward with lots of fun along the way, how to communicate even if it is uncomfortable, and last but not least how to work around people no matter how terrible and disagreeable that person may be. She also taught be how to better manage personal and work relationships, and how to keep a better work/life balance... Thanks boss lady! I also want to thank Dr. Eirin-Lopez, who taught me epigenetics and the effects the environment can have on evolution, and for offering his encouragement along the way; Dr. Eric Cole, whom I meet as an undergrad. He taught me a lot about bushwhacking and San Sal, he was always a helpful sounding board for ideas and places to travel, and he is truly one of the most positive people I have ever met; Dr. Eric Bishop von Wettberg, who helped guide me through population genetics and gave me a lot of helpful feedback on useful software to tryout and experimental design; Dr. Jessica Siltberg-Liberles, for teaching sound bioinformatics practices and providing me feedback on all of my bioinformatics questions; Dr. Dean Whitman who helped me understand my results on a geographic timeline and to puzzle out important events in the geologic record; and Dr. Demian Chapman, who happily took over the spot of a committee member that had left the university. I am grateful to the members of the CRUSTOMICS lab for all of their help over the years, especially Dr. Jorge Pérez-Moreno for putting up with my shenanigans; 
Dr. Laura Timm, for letting me pick her brain; and Dr. Daniel Deleo for being the best postdoc anyone can ask for and whom helped turn my $\mathrm{PhD}$ experience into a positive one. I would like to say, thank you, to William "Bill" Chamberlain, whom I do not think the Marine Science program or the Marine Science Program, cheers. I am also very grateful to Drs. Rob Erdman (Big Rob), Anna Goebel, Randy Cross and the rest of the FGCU Marine Science faculty. They gave me amazing guidance early on during my undergrad and I cannot say how much I appreciate them. I offer my thanks to Ms. Claire Burgett and Ms. Aubree Zenone, who taught me to value all perspectives, whose friendship helped me through many difficulties along the way, and Claire taught me how to art $\odot$. And, of course, I would like to thank my parents.

I would also like to thank Drs. Thomas Iliffe, T.-Y. Chan, Darryl Felder, Craig Layman and Jocelyn Curtis-Quick and the Cape Eleuthera Institute, The Bahamas for their assistance in the collection of specimens. I also thank the curators at USNM and MNHN for providing valuable additional material of Parhippolyte. I would like to thank Dr. John E. Mylroie for his valuable feedback and assistance. I also extend my gratitude to Drs. Raymond Bauer for his expert advice and feedback. I am grateful for the support and assistance of the Gerace Research Centre and Bahamian citizens during field work on San Salvador, Bahamas. These studies were supported in part by a student research award from the Gerace Research Centre, The Crustacean Society - Graduate Student Fellowship, The National Speleological Society - Ralph Stone Graduate Fellowship Grant, and Florida International University Tropics graduate research grant awarded to RED. Additional support was provided by Florida International University. 


\author{
ABSTRACT OF THE DISSERTATION \\ CONNECTIONS IN THE UNDERWORLD: A MORPHOLOGICAL AND \\ MOLECULAR STUDY OF DIVERSITY AND CONNECTIVITY AMONG \\ ANCHIALINE SHRIMP \\ by
}

Robert E Ditter

Florida International University, 2020

Miami, Florida

Professor Heather D. Bracken-Grissom, Major Professor

This research investigates the distribution and population structure of crustaceans endemic to anchialine systems in the tropical western Atlantic focusing on cave-dwelling shrimp from the family Barbouriidae. Taxonomic and molecular tools (genetic and genomic) are utilized to examine population dynamics and the presence of phenotypic hypervariation (PhyV) of the critically endangered species Barbouria cubensis (von Martens, 1872). The presence of PhyV and its geographic distribution is investigated among anchialine populations of B. cubensis from 34 sites on Abaco, Eleuthera, and San Salvador, Bahamas. Examination of 54 informative morphological characters revealed PhyV present in nearly $90 \%$ ( $\mathrm{n}=463)$ of specimens with no identifiable geographic distribution. Updated range descriptions of Macrobrachium lucifugum Holthuis, 1974, Parhippolyte sterreri (Hart \& Manning, 1981) and B. cubensis in the western Atlantic are provided with observations on the behavior of B. cubensis from over 10 years of work. Molecular phylogenetic analyses of a combination of two mitochondrial and five nuclear gene regions are used for molecular barcoding, to further investigate PhyV and to 
re-examine the current classification of the family Barbouriidae. The results find no evidence of cryptic speciation, or genetic differentiation among individuals of B. cubensis $(\mathrm{n}=72)$. Morphological and molecular evidence supports synonymizing Janicea within Parhippolyte and recognition of the sub-families Calliasmatinae Ditter et al., 2020 and Barbouriinae Christoffersen, 1987. Connectivity among anchialine systems and population structure of B. cubensis across the tropical western Atlantic is examined using a combination of next generation molecular tools. Genomic analyses suggest a single highly connected population of $B$. cubensis with low genetic diversity and a low effective population size, which conflicts with the generally accepted isolation paradigm of anchialine systems. Our findings support the value added to genomic studies by generating a partial draft genome constructed using de novo hybrid assembly of short read RADseq and Nanopore long read sequencing data through the investigation of the anchialine isolation paradigm. 
CHAPTER

PREFACE 1

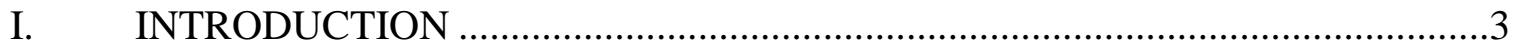

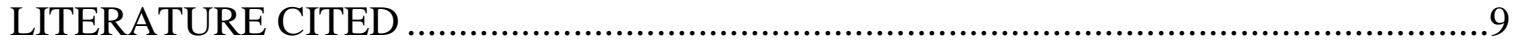

II. WIDESPREAD PHENOTYPIC HYPERVARIATION IN THE ENIGMATIC ANCHIALINE SHRIMP BARBOURIA CUBENSIS (DECAPODA:

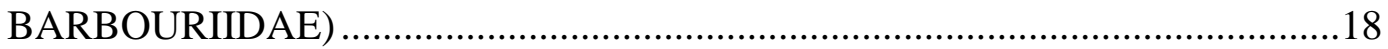

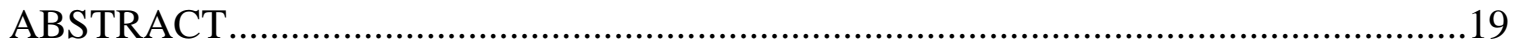

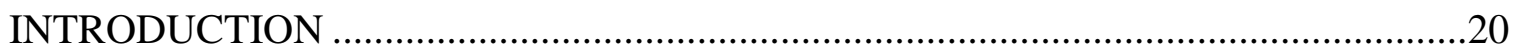

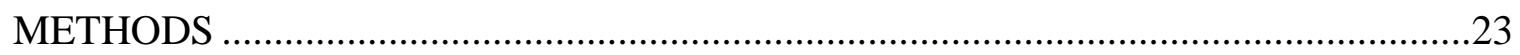

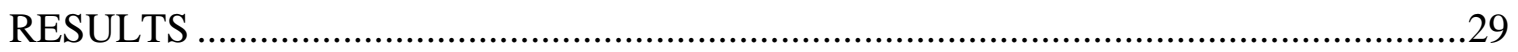

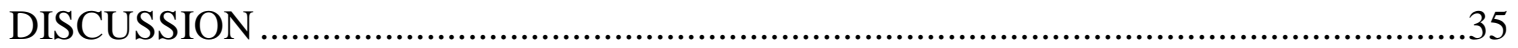

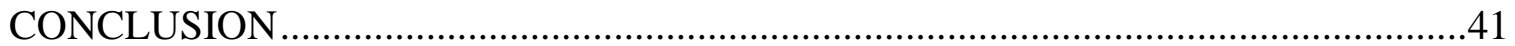

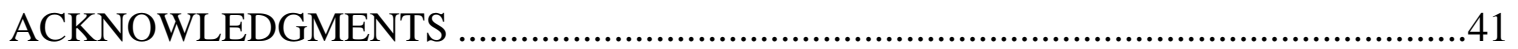

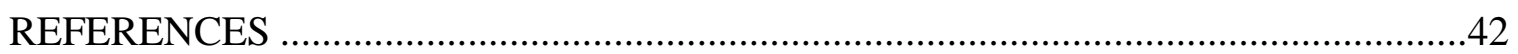

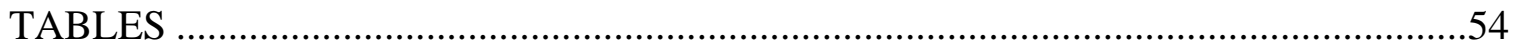

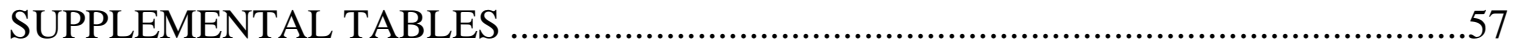

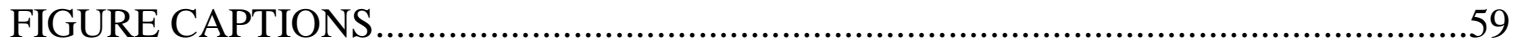

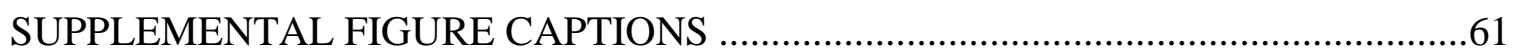

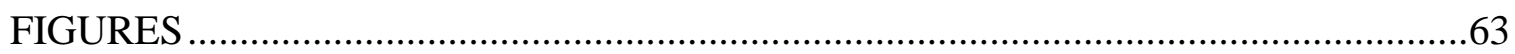

SUPPLEMENTAL FIGURES .............................................................................69

III. NOTES ON THE BEHAVIOR AND FIRST RECORDS OF THREE

ENIGMATIC ANCHIALINE SHRIMPS (DECAPODA: CARIDEA:

BARBOURIIDAE, PALAEMONIDAE) IN THE BAHAMAS …………...........72

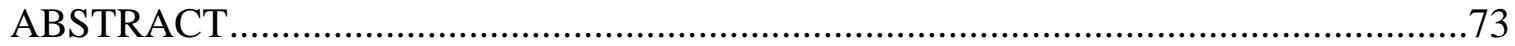

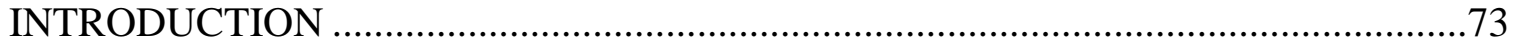

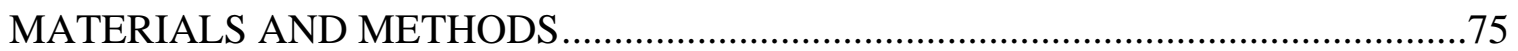

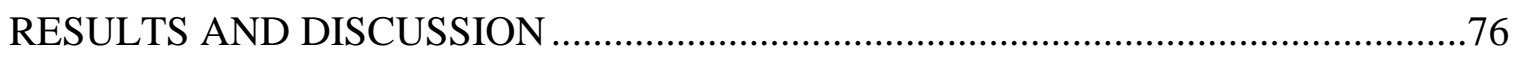

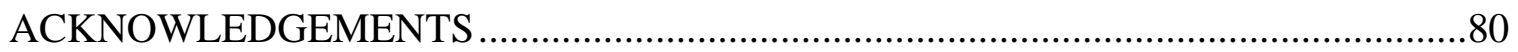

REFERENCES …

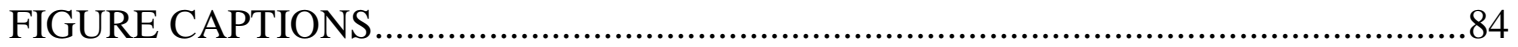

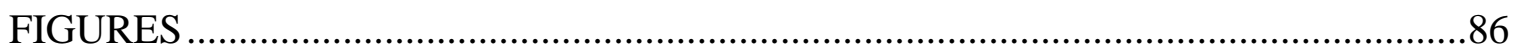

IV. ANCHIALINE ADJUSTMENTS: AN UPDATED PHYLOGENY AND

CLASSIFICATION FOR THE FAMILY BABOURIIDAE

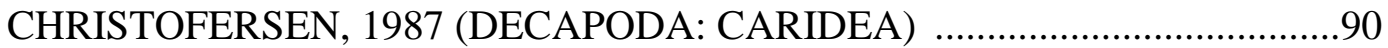

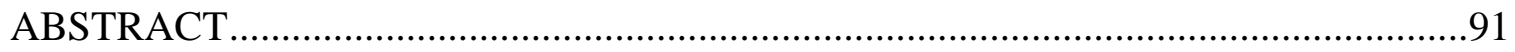

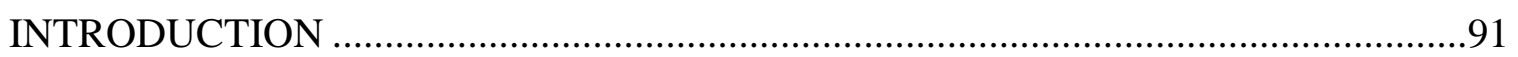

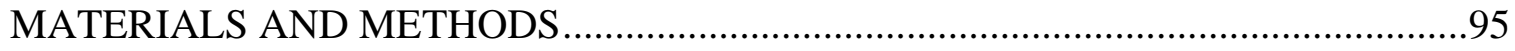

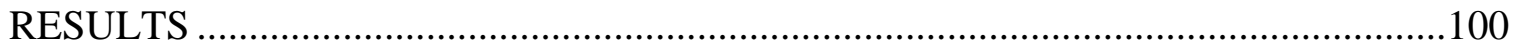


RECLASSIFICATION OF BARBOURIIDAE …………........................................102

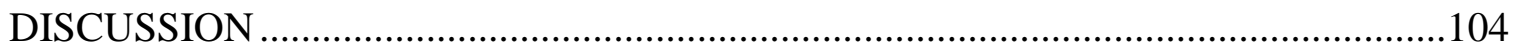

KEY FOR SUBFAMILIES BARBOURIINAE AND CALLIASMATINAE .................109

KEY TO SPECIES OF CALLIASMATA, SUBFAMILY CALLIASMATINAE .............110

KEY TO GENERA OF SUBFAMILY BARBOURIINAE .........................................111

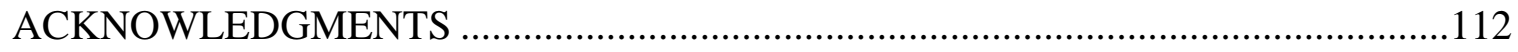

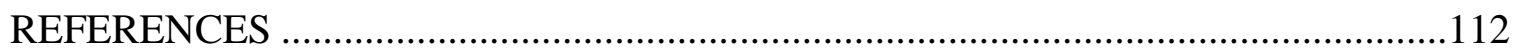

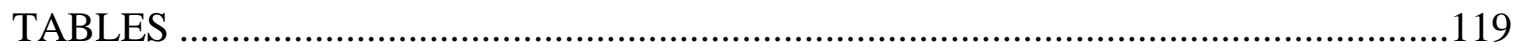

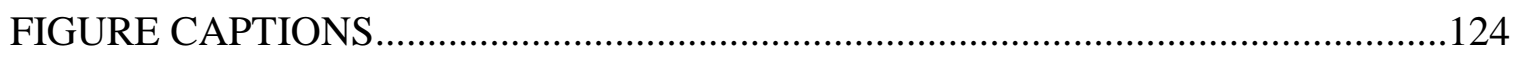

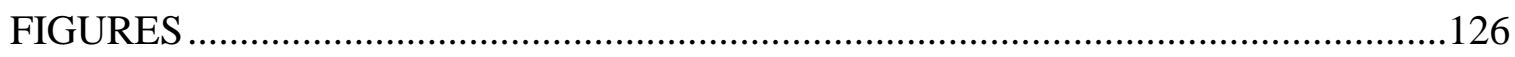

SUPPLEMENTARY MATERIAL (CAPTIONS) …………....................................131

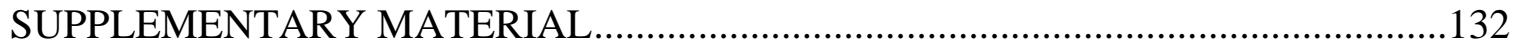

V. ENDANGERED CAVE SHRIMP REVEAL HIGH CONNECTIVITY DESPITE AN ANCHIALINE ISOLATION PARADIGM ACROSS THE TROPICAL WESTERN ATLANTIC (DECAPODA: CARIDEA:

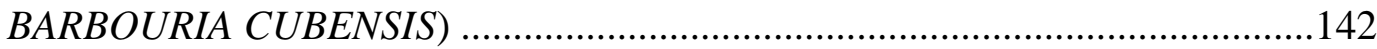

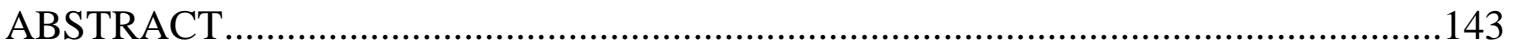

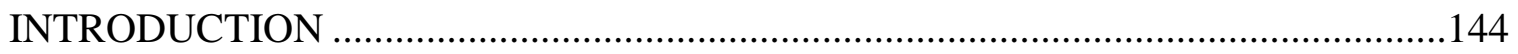

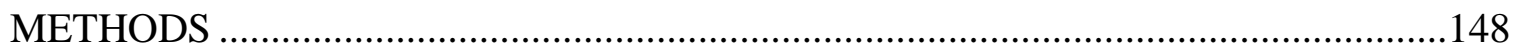

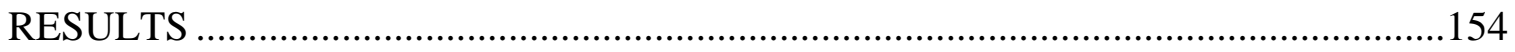

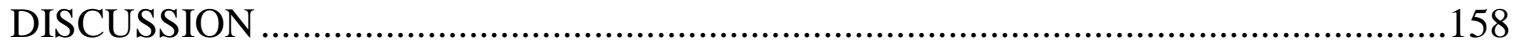

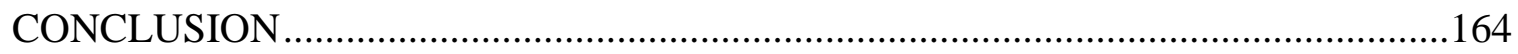

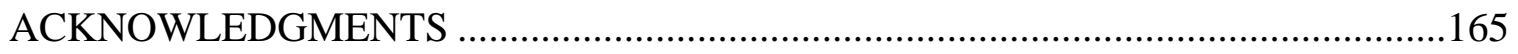

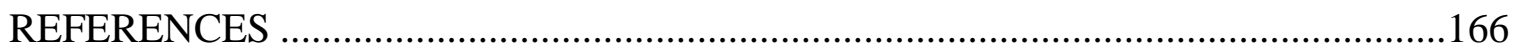

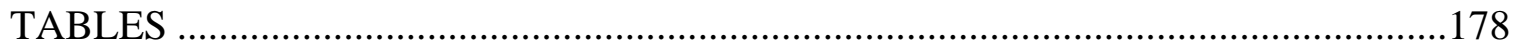

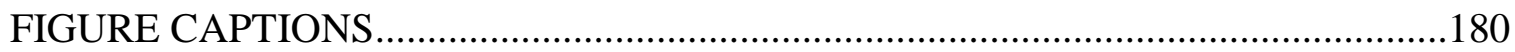

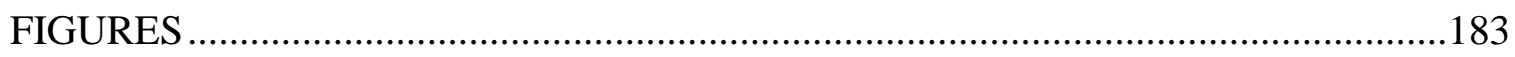

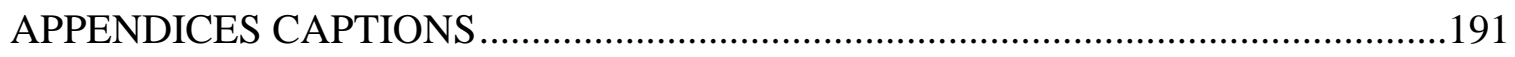

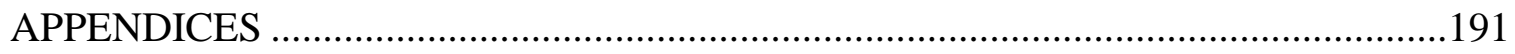

VI. CONCLUSIONS AND FUTURE DIRECTIONS .............................................193

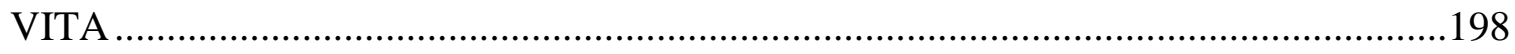




\section{CHAPTER II}

1 Common morphological characters used to discriminate among $\underline{\text { Barbouriidae }}$ $\underline{s p p}$. separated by prescribed character states for Barbouria cubensis, $\underline{\text { B. yanezi, }}$, Parhippolyte sterreri and Janicea antiguensis, and the most common, extremes and percentage of individuals exhibiting PhyV. * denotes percentages for which the character was examined for $\geq 121$ individuals. Reproduced with permission from Magnolia Press

2 Species used for phylogeny reconstruction for examining cryptic diversity within Barbouria cubensis (Dataset 1), showing taxon, collection locality, catalog number, and GenBank accession numbers for partial sequences of 16S, COI respectively Reproduced with permission from Magnolia Press.

S1 Morphological characters included in data subset 1t and 1b. Reproduced with permission from Magnolia Press ...........................................................................57

S2 Additional morphological characters used in data subset $2 \mathrm{t}$ and $2 \mathrm{~b}$. Reproduced with permission from Magnolia Press

S3 morphological characters used to evaluate sexual dimorphism in place of characters used in data for 1 st and 2 nd pleopods. Reproduced with permission from Magnolia Press

\section{CHAPTER IV}

1 Species used in phylogenetic reconstruction for the family Barbouriidae [see Material and Methods for the museum abbreviations]. Accession numbers for partial sequences of COI we generated using the LCO1490/HCO2198 and F/10 primers respectively. Individuals with successful amplification for both regions will have two accession numbers for the COI gene ....

2 Original and corrected identifications of taxa in Barbouriidae. See Material and Methods for museum abbreviations

3 Mean (and standard error) of genetic distances between genera of Barbouriidae for the $16 \mathrm{~S}$ partial gene regions Type chapter title (level 1)....

4 Genetic distances for the $\mathrm{CO} 1$ partial gene region in species of Barbouriidae amplified with the F/10 primers. GenBank accession numbers and alternative museum catalog numbers are listed in Table 1. Individuals with asterisk (*) represent misidentified species in GenBank. See Table 2 for the correct identifications

5 Comparison between diagnostic characters of Barbouriinae and Calliasmatinae.

\section{CHAPTER V}

$1 \quad$ Mean measures of genetic diversity for 47 Barbouria cubensis from four geographical populations calculated from random unlinked single nucleotide polymorphic loci for the BcubSNP, BcubGNM, and PcarGNM datasets (generated with identical "populations" 2.53 parameters). 
2 Measures of genomic diversity for 47 Barbouria cubensis from for geographical populations calculated using the FSD from random unlinked single nucleotide polymorphic loci and $0 \%$ missing loci between individuals or within 179

3 Measures of genomic diversity between populations of Barbouria cubensis from for geographical populations within the Bahamas and the Yucatán Peninsula, Mexico, calculated using the FSD dataset from random unlinked single nucleotide polymorphic loci and $0 \%$ missing loci between individuals or within populations Appendix Table $1 \quad$ Metadata for all samples included in this study, including Florida International Crustacean Collection (FICC) museum catalog number, collection locality, collection site, collection date and GPS coordinates for the collection site. *, individual used to for partial draft genome assembly 


\section{CHAPTER II}

1 Barbouria cubensis, (top) left lateral view of live specimen (HBG1911), (bottom) schematic drawing by R.E. Ditter of general morphological characters within Caridea. Reproduced with permission from Magnolia Press

2 Map of Bahamian Islands with sites sampled from 2012-2016 (a) Abaco site codes and names labeled from North to South: ADS, Dripping Stones; ALP, Lora's Pond; ARS, Runge's Sinkhole (b) Eleuthera site codes and names labeled from North to South: EPC, Preacher's Cave Blue Hole; EDM, Dump Pond; ETD, Too Deep Pond; ESS, Savannah Sound; ESP, Shrimp Pond; EMN, Mackery Nixon Pond (c) San Salvador site codes and names labeled from northern most moving clockwise: LHC, Light House Cave; SSL, South Stout's Lake; MDP, Mermaid Pond; MNP, Merman Pond; PCC, Pigeon Creek Conduit; DCP, Dunk City Pond; WBH, Watling's Blue Hole; BH2, Blue Hole \#2; BH5, Blue Hole \#5; RED, Redrum Pond; WLL, William's Pond; LIL, Little Lake; MJC, Major's Cave. $\boldsymbol{i}$; site codes and names labeled from northern most moving clockwise: RHP, Reckley Hill Pond; PNP, Pain Pond; WDP, Wild Dilly Pond; OYP, Oyster Pond; SHP, Shrimp Holes. $i \boldsymbol{i}$; site codes and names labeled from North to South: PTN, Plantation Pond; SPX, Small Pox Pond; RBH, Rolle's Blue Hole; LRP, Tilde Pond; BRP, Big Rob Pond; BDP, Big Drink Pond. Reproduced with permission from Magnolia Press

3 Expected phenotypes for $\underline{B}$. cubensis (left column) compared to examples of observed variable phenotypes; (a-d) teeth on rostrum and rostrum length, and the presence of antennal and branchiostegal spines $(\mathrm{e}-\mathrm{h})$ rostrum length, teeth and shape, antennal and branchiostegal teeth and abnormalities of carapace (i-l) eyes, cornea width versus eyestalk width, and the presence of spines on eyestalk. Images correspond to the following catalog numbers for specimen vouchers housed in the Florida International Crustacean Collection: a*, HBG1843; b, HBG2162; c, HBG2011; d, HBG5644; e*, HBG1843; f, HBG2139; g, HBG2095; h, HBG1935; i*, HBG1843; j, HBG 1952; k, HBG1776; 1, HBG2217. Reproduced with permission from Magnolia Press

3 con't. (m-p) shape and armament of pleura of the abdominal somites ( $q-t)$ telson shape, dorsal spines and terminal spines $(\mathrm{u}-\mathrm{x})$ shape and spines of terminal margin of telson. Yellow lines and arrows indicate expected characters, red lines and arrows indicate variable characters. * denotes examples of expected phenotypes for $B$. cubensis. Images correspond to the following catalog numbers for specimen vouchers housed in the Florida International Crustacean Collection: m*, HBG1843; n, HBG1932; o, HBG1934; p, HBG1398; q*, HBG1843; r, HBG1936; s, HBG1937; t, HBG1970; u*, HBG1843; v, HBG1777; w, HBG1937; x, HBG2098. Reproduced with permission from Magnolia Press ....

4 An unweighted pair-group method with arithmetic averages (UPGMA) dendrogram of morphological data in Subset \#2 labeled with site codes

corresponding to figure 2 . Bootstrap values $>90 \%$ are noted to the right of nodes. Reproduced with permission from Magnolia Press 
5 Bayesian (BI) phylogram for Barbouria cubensis $(\mathrm{n}=70)$ based on a $16 \mathrm{~S} \&$ COI concatenated data set. BI posterior probabilities and Maximum Likelihood (ML) bootstrap values noted below branches. Values $>0.7$ for ML and $>90 \%$ for BI are shown and represented by percentages. Vertical bars represent collection locality. $\mathrm{AIB}=$ Abaco, Bahamas, EIB = Eleuthera, Bahamas, MIB = Mayaguana, Bahamas, SSB = San Salvador, Bahamas, and YMx = Yucatán, Mexico. Catalog numbers represent tissue vouchers from the Florida International Crustacean Collection (FICC). Reproduced with permission from Magnolia Press

S1 Phenotypic hypervariation exhibited by B. cubensis; $(\mathrm{a}-\mathrm{c})$ variations in the shape and surface of the carapace, $(\mathrm{d}-\mathrm{f})$ additional and missing teeth without carina, $(\mathrm{g}-\mathrm{h})$ position of sensory dorsal organ associated with epigastric tooth and within the cardiac region $(j-1)$ asymmetry in the presence of cornea pigmentation and a terminal spine or tubercle on the eyestalk. Images correspond to the following catalog numbers for specimen vouchers housed in the Florida International Crustacean Collection: a, HBG1793; b, HBG1918; c, HBG2215; d \& e, HBG1808; f, HBG1909; g-i, 1801 HBG; j-1, HBG1849. Reproduced with permission from Magnolia Press

S2 Phenotypic hypervariation exhibited by B. cubensis; (a) asymmetrical lateral compression of scaphocerite, and the absence of the rostrum and antennal tooth while the carina is present $(b \& c)$ dorsal and ventral view of the ischium of the $2^{\text {nd }}$ pereiopod with six subdivisions (d) lateral extrusions along carapace, (e) bifid rostrum, antennal and branchiostegal spines absent and carapace not smooth (f) rhizocephalan parasite, $(\mathrm{g}-1)$ additional examples of PhyV in character located on the cephalothorax. Images correspond to the following catalog numbers for specimen vouchers housed in the Florida International Crustacean Collection: a, HBG1907; b \& c, HBG1904; d, HBG2227; e, HBG2011; f, HBG2083; g, HBG1816; h, HBG1872; i, HBG1882; j, HBG2095; k, HBG1982; 1, HBG1793. Reproduced with permission from Magnolia Press

S3 Phenotypic hypervariation exhibited by B. cubensis; (a \& b) abnormal shape and armament of the pleura of the abdominal somites, $(\mathrm{d}-1)$ additional examples of PhyV in characters located on the telson and uropods. Images correspond to the following catalog numbers for specimen vouchers housed in the Florida International Crustacean Collection: a, HBG2093; b, HBG1398; c, HBG1399; d, HBG1793; e, HBG1802; f, HBG1791; g, HBG1777; h, HBG1395; i, HBG1954; j, HBG1982; k, HBG1855; 1, HBG1853. Reproduced with permission from Magnolia Press

\section{CHAPTER III}

1 Map of Acklins, Bahamas adapted from Google Earth indicating the collection sites of Barbouria cubensis, Parhippolyte sterreri, and Macrobrachium lucifugum and the location of Jumbey Hole Cave. Magnified view of Harour Hill Cenote (A), Harbour Hill Cave (B), and Red Lantern Cave (D). Scale bar $=50 \mathrm{~m}$. This figure is available in color at Journal of Crustacean Biology online. Reproduced with permission of Oxford University Press 
2 Dorsal views of Barbouria cubensis (A), Parhippolyte sterreri (B), and Macrobrachium lucifugum (C). Scale bar $=1 \mathrm{~cm}$. This figure is available in color at Journal of Crustacean Biology online. Reproduced with permission of Oxford University Press

3 Left lateral view of an individual of Barbouria cubensis exhibiting color change before and after light exposure, being nearly translucent pale when not exposed to light, (A) and deep red/crimson after five minutes of exposure to direct light (B). Scale bar $=1 \mathrm{~cm}$. This figure is available in color at Journal of Crustacean Biology online. Reproduced with permission of Oxford University Press

4 Dorsal view of the cephalothorax of Barbouria cubensis cephalothorax (40x magnification) with distinct small red and large white chromatophores visible. Scale bar $=1 \mathrm{~mm}$. This figure is available in color at Journal of Crustacean Biology online . .85

\section{CHAPTER IV}

1 Examples of Barbouriidae taxa. Parhippolyte uveae (Photo by MeerwasserAquaristik-Studio-Korallenkiste) (A). Barbouria cubensis (Photo by R.E. Ditter) (B). Parhippolyte cavernicola (Photo by A. Kerstitch) (C). Parhippolyte sterreri (Photo by R.E. Ditter) (D). Parhippolyte misticia (Photo by J. Starmer in Legall \& Poupin, 2018) (E). Janicea antiguensis (Photo by T. Iliffe) (F). Reproduced with permission of Oxford University Press

2 Distribution of the genera Barbouria, Calliasmata, Janicea and Parhippolyte. $P$. rukuensis excluded because it was described from a single female collected from Yeh-Him Island, Ryukyu Archipelago, Japan. Reproduced with permission of Oxford University Press

3 Bayesian $(\mathrm{BI})$ phylogram for Barbouriidae $(N=8)$ based on a $16 \mathrm{~S}, 28 \mathrm{~S}, \mathrm{COI}$, Enolase, H3, NaK and PEPCK concatenated data set. BI posterior probabilities and Maximum Likelihood (ML) bootstrap values noted above branches. Values $>0.7$ for ML and $>90 \%$ for BI are shown and represented by percentages. Vertical black bars represent the native range for each species. Catalog numbers represent voucher specimens housed in the Florida International Crustacean Collection (FICC). * Indicates a clade likely comprised of a single species. ** Indicates chimeric individuals. Reproduced with permission of Oxford University Press....

4 Sensory Dorsal Organ (SDO) of Barbouriidae on Barbouria cubensis

(Illustrated by R. E. Ditter). SDO associated with, and posterior to the epigastric tooth (A). Single large SDO within cardiac region, and a small pair juxtaposed to the larger SDO (B). Scale bar $=1 \mathrm{~mm}$. Reproduced with permission of Oxford University Press

$5 \quad$ Illustrated examples of Barbouriidae taxa. Parhippolyte uveae (from Fransen \& Tomascik, 1996, fig. 1) (A). Barbouria cubensis (from Hobbs, Hobbs \& Daniel 1977, fig. 33) (B). Parhippolyte cavernicola (from Wicksten, 1996, fig. 1) (C). Parhippolyte sterreri formerly Somersiella sterreri (from Hart \& Manning, 1981, fig. 1) (D). Parhippolyte misticia (from Clark, 1989, fig. 1) (E). Janicea antiguensis (from Chace, 1972, fig. 40b) (F). Reproduced with permission of Oxford University Press ...... 
S1 16S loci phylogeny with support values calculated using RAxML.

Reproduced with permission of Oxford University Press

S2 28S loci phylogeny with support values calculated using RAxML.

Reproduced with permission of Oxford University Press

S3 Enolase loci phylogeny with support values calculated using RAxML.

Reproduced with permission of Oxford University Press

S4 H3 loci phylogeny with support values calculated using RAxML.

Reproduced with permission of Oxford University Press

S5 NaK loci phylogeny with support values calculated using RAxML. R

eproduced with permission of Oxford University Press.

S6 PEPCK loci phylogeny with support values calculated using RAxML.

Reproduced with permission of Oxford University Press

S7 COI loci (amplified with F/10 primers) phylogeny with support values

calculated using RAxML. Reproduced with permission of Oxford University

Press

S8 COI loci (amplified with LCO1490/HCO2198 primers) phylogeny with

support values calculated using RAxML. Reproduced with permission of Oxford University Press

S9 Heat map and genetic distances (DA) for the 16S partial gene region.

Reproduced with permission of Oxford University Press

S10 Material of Barbouriidae examined. Reproduced with permission of Oxford

University Press

\section{CHAPTER V}

$1 \quad$ Workflow for generating and comparing de novo, Barbouria cubensis partial draft genome referenced and Palaemon carnicauda genome referenced SNP assembly test datasets

2 An example of the histograms of k-mer counting used as part of estimating genome size and scaffold contiguity

3 (A) fastSTRUCTURE analysis without admixture using total number of sample sites as the maximum number of clusters $(\mathrm{K}=1-29)$. fastSTRUCTURE results are the same for the de novo and aligned test SNP data sets; (B) PCA of Barbouria cubensis de novo assembled SNPs with 95\% confidence ellipse.

4 Proportions of total genetic variance contained within subpopulations; Abaco,

Acklins, San Salvador (SanSal), Bahamas and The Yucatán Peninsula....

5 Inferred population structure for 47 Barbouria cubensis as estimated by the software STRUCTURE using the ancestry linkage model (top); inferred number of populations and populations admixture for 827 SNPs as estimated by the software ADMIXTURE (bottom); PCA of Barbouria cubensis using the final dataset of 827 SNPs (right)

6 Haplotype networks constructed using phased haplotypes from finalized SNP dataset (top), and a corresponding haplotype network map of the western Atlantic (bottom) 
7 Diversity metrics (observed heterozygosity $H_{o}$, expected heterozygosity $H_{e}$, and inbreeding coefficient $G_{I S}$ ) are compared between collection localities in the Bahamas and Mexico for Barbouria cubensis (note $H_{o}$ and $H_{e}$ are on the primary $\mathrm{y}$-axis and $G_{I S}$ are on the secondary y-axis)

$8 \quad$ Relative migration levels between populations of Barbouria cubensis in the western Atlantic generated with the "divMigrate" function of diversity package in R. Manually depicted populations with $N_{m}$ values (A), Jost's D (B) and $G_{S T}$ models. The direction of arrows indicates the direction and thickness represents the magnitude of gene flow. (1) Abaco, Bahamas (2) San Salvador, Bahamas, (3) Acklins, Bahamas and (4) the Yucatán Peninsula, Mexico. 


\section{PREFACE}

The following chapters have been or will be submitted for publication and are formatted according to journal specifications:

\section{CHAPTER II}

Ditter, R. E., Erdman, R. B., Goebel, A. M., and Bracken-Grissom, H. D. 2019.

Widespread phenotypic hypervariation in the enigmatic anchialine shrimp Barbouria cubensis (Decapoda: Barbouriidae). Zootaxa, 4648(1): 1-26. [Reproduced with permission from copyright holder, Magnolia Press]

\section{CHAPTER III}

Ditter, R. E., Snyder, A. P., Schulman, S. E., and Bracken-Grissom, H. D. 2019. Notes on the behavior and first records of three enigmatic anchialine shrimps (Decapoda: Caridea: Barbouriidae, Palaemonidae) in the Bahamas. Journal of Crustacean Biology, 39(6): 684-688. [Reproduced with permission from copyright holder, Oxford University Press]

\section{CHAPTER IV}

Ditter, R. E., Mejía-Ortíz, L. M., and Bracken-Grissom, H. D. 2020. Anchialine adjustments: an updated phylogeny and classification for the family Barbouriidae Christoffersen, 1987 (Decapoda: Caridea). Journal of Crustacean Biology, 40(4): 401411. [Reproduced with permission from copyright holder, Oxford University Press] 


\section{CHAPTER V}

Ditter, R. E., Mejía-Ortíz, L. M., and Bracken-Grissom, H. D. In prep. Endangered cave shrimp reveal high connectivity despite an anchialine isolation paradigm across the tropical western Atlantic (Decapoda: Caridea: Barbouria cubensis). 


\section{CHAPTER I}

INTRODUCTION 
A common feature of the tropical western Atlantic are anchialine habitats with unique and endemic species (Iliffe, 2002). Anchialine communities exhibit characteristics of isolated populations, which allow them to function as natural laboratories (Edwards, 1996; Iliffe, 2002), making them ideal for studies regarding evolution, speciation and adaption (Sket, 1996; Dawson, 2005; Humphreys et al., 2009; Christian et al., 2010; Gonzalez et al., 2011; Protas, et al., 2011; Bishop \& Iliffe, 2012; Iliffe, 2012; Becking et al., 2013; Martin \& Wainwright, 2013; Weese et al., 2013). Anchialine ecosystems have provided insight into ancient communities prior to the dominance of vertebrates (Humphreys et al., 2009; Becking et al., 2013; Rose et al., 2016). Often occurring in areas of high demand for tourism, anchialine habitats are being rapidly altered by development, pollution, and climate change (Wilson, 1985; Sket, 1999; Iliffe, 2002; Schawbe et al., 2010 Iliffe et al., 2015). Anchialine organisms are easily impacted by disturbances resulting from their endemism or restricted distributions, as a consequence of being high specialized for specific environmental conditions or low genetic diversity respectively (Humphreys et al., 2009; Becking et al., 2013). Conservation of these unique systems is increasingly urgent. As anchialine habitats are being destroyed the opportunity of substantial discoveries are quickly vanishing (Iliffe, 2002; Pérez-Moreno et al., 2016).

The present uses traditional taxonomic and molecular techniques to examine genetic diversity, evolution, phylogeography, and the recent appearance of phenotypic hypervariation among anchialine shrimp within the family Barbouriidae to increase our understanding of anthropogenic impacts on anchialine ecosystems. To study these impacts, specimens collected were used in taxonomic and phylogenetic studies to examine population structure and potential sources of phenotypic hypervariation. The 
current study resulted in an improved understanding of the evolutionarily relationships, estimates of population health, and an enhanced understanding of the connections and origins of anchialine organisms.

Advances in molecular techniques provide novel approaches and high-resolution information for studying non-model organisms and habitats with limited accessibility. With many prevalent anthropogenic threats and the delicate nature of anchialine habitats, the need to advance our understanding of these systems is clear. Next-generation molecular tools provide a scale of resolution previously not attainable and offer the ability to answer long-standing questions of the population dynamics and evolutionary processes underlying life in anchialine habitats. The study utilized a multitude of approaches to the study of non-model organisms, from traditional taxonomic methods to high resolution population analyses utilizing a partial draft genome assembled from a combination of Oxford NanoPore long read and Illumina short read genomic sequencing data.

Widespread phenotypic hypervariation in the enigmatic anchialine shrimp Barbouria cubensis (Decapoda: Barbouriidae)

Among anchialine crustaceans is a group of enigmatic shrimps from the family Barbouriidae Christoffersen, 1987 (Manning \& Hart, 1984, De Grave et al., 2009). Barbouriid shrimps have a been described as having a tethyan distribution pattern along tropical latitudes (Manning \& Hart, 1984). As a result of limited habitat availability, species of Barbouriidae have been placed on the IUCN's Red List (Iliffe, 1996). Barbouria cubensis is a species found exclusively in anchialine pools throughout the 
tropical western Atlantic ranging from the Bahamas, Bermuda, Turks and Caicos, Cayman Brac and the Yucatán Peninsula (Mejía-Ortiz et al., 2008).

Previous records have documented slight morphological variations for B. cubensis limited to the spines and length of the rostrum, ratio of length versus width of the scaphocerite, number of subdivisions of the second pereiopods, length and spination of the appendix masculina and the body size of the species (Rathbun, 1912; Chace, 1972; Holthuis, 1973; Hobbs et al., 1977; Hobbs, 1978; Hart \& Manning, 1981; Hart et al., 1985). Recent exploration of anchialine pools on the Bahamian islands of San Salvador, Eleuthera and Abaco from 2012-2015 has not only revealed the presence of extensive morphological variation in the previously documented variable characters, but also extends to an additional 50 morphological characters. On the basis of the high rate and extensive range of morphological variation that greatly deviates from any previous taxonomic records we described the presence of these phenotypes as phenotypic hypervariation (PhyV). Our objectives were to document PhyV exhibited by B. cubensis from three Bahamian islands, determine if PhyV is associated with geographic distribution, and to confirm the identity of morphologically variable specimens using molecular barcoding of two partial mitochondrial gene regions (16S and COI).

Notes on the behavior and first records of three enigmatic anchialine shrimps (Decapoda: Caridea: Barbouriidae, Palaemonidae) in the Bahamas

A common feature of anchialine systems are the rare and often endemic species found within them (Edwards, 1996; Iliffe, 2005; Sket, 2005). The biodiversity within anchialine systems is presently being threatened by anthropogenic activity leading to habitat 
destruction (Iliffe et al., 1984; Culver \& Sket, 2000; Iliffe \& Kornicker, 2009). Among anchialine inhabitants Barbouria cubensis (von Martens, 1872) and Parhippolyte sterreri (Hart \& Manning, 1981) are listed by the IUCN (2019) as critically endangered. It is imperative to study threatened anchialine species so that appropriate management efforts can be made to protect these enigmatic organisms. To this end, we reported on the first occurrence of Barbouria cubensis, Parhippolyte sterreri and Macrobrachium lucifugum Holthuis, 1974 in the anchialine pools of Acklins, Bahamas. We also discussed observations made for these species during collections as well as the behavior of $B$. cubensis in its natural habitat and in a laboratory setting over a 2 -year period.

Anchialine adjustments: an updated phylogeny and classification for the family Barbouriidae Christoffersen, 1987 (Decapoda: Caridea)

Molecular methods can be especially useful to delineate species, especially when traditional taxonomic identification is not possible (e.g., metamorphic life stages). DNA barcoding is particularly useful for B. cubensis as PhyV has led to conflicted morphological identifications. Variances in genetic data can be sufficient to delineate species among morphologically similar individuals in taxa that form cryptic species complexes (Brian et al., 2006; Bracken-Grissom et al., 2014). For B. cubensis, where no geographic pattern of PhyV was detected, it is possible that other unconsidered barriers may exist. The family Barbouriidae has undergone substantial revisions in recent years (Christoffersen, 1989; Christoffersen, 1990). The evolutionary history of the family remains unclear and presently lacks a formal description (De Grave et al., 2009; De Grave et al., 2014). Recent collections have allowed us to include a greater number of 
representative genera and gene regions than prior studies (Bracken et al., 2009; Li et al., 2011; Baeza, 2013; Aznar-Corman et al., 2015). Our objective was to revisit the current classification and clarify the relationships among genera of Barbouriidae.

Endangered cave shrimp reveal high connectivity despite an anchialine isolation paradigm across the tropical western Atlantic (Decapoda: Caridea: Barbouria cubensis)

The family Barbouriidae are endemic to disjunct anchialine systems, nominating them as valuable species for investigating connectivity among vulnerable anchialine communities Dawson, 2005; Christin et al., 2010; Becking et al., 2013; Weese et al., 2013; Rose et al., 2016). Among them, Barbouria cubensis has the broadest distribution in the western Atlantic, however their dispersal abilities remain unknown (Bohonak, 1999; Kano \& Kase, 2004; Oha \& Paal, 2004; Santos, 2006; Turner et al., 2008; Russ et al., 2010; Onaga et al., 2012).

The advent of next generation molecular techniques (e.g. RADseq) permits unprecedented resolution for a variety of long-standing questions regarding phylogeography and population structure (Davey \& Blaxter 2010; Eaton \& Ree, 2013; McCormack et al., 2013; Timm \& Bracken-Grissom, 2015). However, the effectiveness of population level analyses using RADseq data alone is limited in organisms that lack full genome sequences, because of its inability to calculate effective population size $\left(N_{E}\right)$ and Linkage Disequilibrium (LD) (Ekblom \& Galindo, 2011; Hoban et al., 2016). Having a reference genome when conducting population analyses allows the calculation of $N_{E}$, LD, and allows the analysis of genomic structural variations (Calafell et al., 2001; Li \& Durbin, 2009; Istace et al., 2017). Using a reference genome also greatly decreases the 
number base calling errors, while it increases the accuracy and coverage depth of genomic data assembly (Austin et al., 2017; Janser et al., 2017; Tan et al., 2017). The present study utilized a de novo hybrid assembly of short read and long read genomic sequences to construct a partial draft genome of $B$. cubensis.

The next-generation molecular approach used in the current study provides high resolution data and potential for answering questions surrounding population connectivity and genetic diversity (Fernandes et al., 2011). We hypothesized that PhyV may be the result of low genetic diversity (i.e., inbreeding) as morphological abnormalities have been correlated to low genetic diversity in other species (McMillan et al., 2006; Duarte et al., 2008; Lacy \& Alaks, 2012). To test the isolation paradigm of anchialine cave systems and to further investigate the source of PhyV next generation molecular techniques are employed to investigate population dynamics and dispersal of the critically endangered $B$. cubensis, (Austin et al., 2017; Janser et al., 2017; Tan et al., 2017).

\section{LITERATURE CITED}

Austin, C.M., M.H. Tan, K.A. Harrison, Y.P. Lee, L.J. Croft, P. Sunnucks, A. Pavlova \& H.M. Gan. 2017. De novo genome assembly and annotation of Australia's largest freshwater fish, the Murray cod (Maccullochella peelii), from Illumina and Nanopore sequencing read. GigaScience, 6(8), 1-6.

Aznar-Cormano, L., Brisset, J., Chan, T.Y., Corbari, L., Puillandre, N., Utge, J., Zbinden, M., Zuccon, D. \& Samadi, S. (2015) An improved taxonomic sampling is a necessary but not sufficient condition for resolving inter-families relationships in Caridean decapods. Genetica, 143, 195-205.

Baeza, J.A. (2013) Molecular phylogeny of broken-back shrimps (genus Lysmata and allies): A test of the 'Tomlinson-Ghiselin' hypothesis explaining the evolution of hermaphroditism. Molecular Phylogenetics and Evolution, 69, 46-62. 
Bauer, R.T. (2005) Library of Congress Cataloging-In-Publication Data Remarkable Shrimps: Adaptations and Natural History of the Carideans. Animal nat. V. H. Hutchison (Ed). University of Oklahoma Press: Norman, Norman, Ok.

Becking, L.E., Erpenbeck, D., Peijnenburg, K.T.C.A. \& de Voogd, N.J. (2013) Phylogeography of the sponge Suberites diversicolor in Indonesia: insights into the evolution of marine lake populations. PLOS One, 8, 1-10.

Becking, L.E., Renema, W., Santodomingo, N.K., Hoeksema, B.W., Tuti, Y. \& de Voogd, N.J. (2011) Recently discovered landlocked basins in Indonesia reveal high habitat diversity in anchialine systems. Hydrobiologia, 677 (1), 89-105.

Bishop, R.E., Humphreys, W.F., Cukrov, N., Žic, V., BOXSHALL, G.A., Cukrov, M., Iliffe, T.M., Kršinić, F., Moore, W.S., Pohlman, J.W., Sket, B., Bishop, R.E., Kršinić, F., Sket, B., Iliffe, T.M., Žic, V., Moore, W.S., Cukrov, N., Cukrov, M., BOXSHALL, G.A. \& Pohlman, J.W. (2015) 'Anchialine' redefined as a subterranean estuary in a crevicular or cavernous geological setting. Journal of Crustacean Biology, 35 (4), 511-514.

Bishop, R.E. \& Iliffe, T.M. (2012) Ecological physiology of the anchialine shrimp Barbouria cubensis: a comparison of epigean and hypogean populations. Marine Biodiversity, 42, 303-310.

Boetzer, M. \& Pirovano, W. (2014) SSPACE-LongRead: scaffolding bacterial draft genomes using long read sequence information. BMC Bioinformatics, 15(1), 211.

Bohonak, A.J. (1999) Dispersal, Gene Flow, and Population Structure. The Quarterly Review of Biology, 74 (1), 21-45.

Borradaile, L.A. (1900) On some Crustaceans from the South Pacific. Part IV. The crabs. Proceedings of the General Meetings for the Scientific Business of the Zoological Society of London, 1900 (3), 568-596.

Bracken-Grissom, H.D., Ahyong, S.T., Wilkinson, R.D., Feldmann, R.M.,C. E. Schweitzer, Breinholt, J.W., Bendall, M., F. Palero, Chan, T.-Y., Felder, D.L., Robles, R., Chu, K.-H., Tsang, L.-M., Kim, D., Martin, J.W. \& Crandall, K.A. (2014) The emergence of the lobsters: phylogenetic relationships, morphological evolution and divergence time comparisons of an ancient group (Decapoda: Achelata, Glypheidea, Polychelida). Systematic Biology, 63, 457-479.

Bracken, H.D., Toon, A, Felder, D.L., Martin, J.W., Finley, M., Rasmussen, J., Palero, F. \& Crandall, K. (2009) The decapod tree of life: compiling the data and moving toward a consensus of decapod evolution. Arthropod Systematics and Phylogeny, 67, 99-116. 
Bradburd, G.S., Ralph, P.L. \& Coop, G.M. (2013) Disentangling the effects of geographic and ecological isolation on genetic differentiation. Evolution, 67, 3258-3273.

Brian, J. V., Fernandes, T., Ladle, R.J. \& Todd, P. a. (2006) Patterns of morphological and genetic variability in UK populations of the shore crab, Carcinus maenas Linnaeus, 1758 (Crustacea: Decapoda: Brachyura). Journal of Experimental Marine Biology and Ecology, 329 (1), 47-54.

Cadena, C.D, Zapata, F. \& Jiménez, I. (2017) Issues and Perspectives in Species Delimitation using Phenotypic Data: Atlantead evolution in Darwin's Finches. Systematic Biology, 67(1), 181-194.

Calafell, F., Grigorenko, E.L. \& Chikanian, A.A. (2001) Haplotype Evolution and Linkage Disequilibrium: A Simulation Study. Human Heredity, 51, 85-96.

Chace, F.A. (1997) The Caridean Shrimps (Crustacea: Decapoda) of the Albatross Philippine Expedition, 1907-1910, part 7: families Atyidae, Eugonatonotidae, Rhynchocinetidae, Bathypalaemonellidae, Processidae, and Hippolytidae. Smithsonian Contributions to Zoology, 587, 1-106.

Chace, F.A. (1972) The shrimps of the Smithsonian-Bredin Caribbean Expeditions with a summary of the West Indian shallow-water species (Crustacea: Decapoda: Natantia). Smithsonian Contributions to Zoology, 98, 1-179.

Christoffersen M.L. (1990) A new superfamily classification of the Caridea (Crustacea: Pleocymata) based on phylogenetic pattern. Zeitschrift für Zoologische Systematik und Evoluationsforschung, 28, 94-106.

Chrsitoffersen, M.L. (1989) Phylogeny and classification of the Pandaloidea (Crustacea, Caridea). Cladistics, 5, 259-274.

Christoffersen, M.L. (1987) Phylogenetic Relationships of Hippolytid Genera, with an Assignment of New Families for the Crangonoidea and Alpheoidea (Crustacea, Decapoda, Caridea). Cladistics, 3 (4), 348-362.

Clark, J. (1989) Koror misticius, new genus, new species (Decapoda: Hippolytidae), a cave shrimp from Palau. Journal of Crustacean Biology, 9 (3), 445-452.

Culver, D.C. \& Sket, B. (2000) Hotspots of subterranean biodiversity in caves and wells. Journal of Cave and Karst Studies, 62, 11-17.

Dawson, M.N. (2005) Incipient speciation of Catostylus mosaicus (Scyphozoa, Rhizostomeae, Catostylidae), comparative phylogeography and biogeography in south-east Australia. Journal of Biogeography, 32 (3), 515-533. 
Davey, J.W. and Blaxter, M.L. 2010. RADseq: next-generation population genetics. Briefings in Functional Genomics, 9(5), 416-423.

De Grave, S., Li, C.P., Tsang, L.M., Chu, K.H. \& Chan, T.Y. (2014) Unweaving hippolytoid systematics (Crustacea, Decapoda, Hippolytidae): Resurrection of several families. Zoologica Scripta, 43, 496-507.

De Grave, S., Pentcheff, N.D., Ahyong, S.T., Chan, T., Crandall, K.A., Dworschak, P.C., Felder, D.L., Feldmann, R.M., Fransen, C.H.J.M., Goulding, L.Y.D., Lemaitre, R., Low, M.E.Y., Martin, J.W., Ng, P.K.L., Schweitzer, C.E., Tan, S.H., Tshudy, D. \& Wetzer, R. (2009) A classification of living and fossil genra of decapod crustaceans. Raffles Bulltein of Zoology, 21, 1-109.

Duarte, M.S., Maia-Lima, F.A. \& Molina, W.F. (2008) Interpopulational morphological analyses and fluctuating asymmetry in the brackish crab Cardisoma guanhumi Latreille (Decapoda, Gecarcinidae), on the Brazilian Northeast coastline. PanAmerican Journal of Aquatic Sciences, 3 (3): 294-303.

Eaton, D. (2014). PYRAD: Assembly of de novo RADseq loci for phylogenetic analyses. Bioinformatics, 30(13), 1844-1849.

Eaton, D.A.R. \& Ree, R.H. (2013) Inferring Phylogeny and Introgression using RADseq Data: An Example from Flowering Plants (Pedicularis: Orobanchaceae). Systematic Biology, 62, 689-706.

Edwards, D.C. (1996) The inland saline waters of the Bahamas as distinctive scientific resources. In: Proceedings of the Sixth Symposium on Natural History of the Bahamas, pp. 152-162.

Ekblom, R. \& Galindo, J. (2011) Application of next generation sequencing in molecular ecology of non-model organisms. Heredity, 107, 1-15.

Fernandes, C.M., Gregati, R.A. \& Bichuette, M.E. (2011) The first record of external abnormalities in the subterranean Aegla marginata Bond-Buckup \& Buckup, 1994 (Crustacea: Decapoda: Aeglidae), from a karst area of Southeastern Brazil. Subterranean Biology, 8, 33-38.

Gonzalez, B.C., Martínez, A., Borda, E., Iliffe, T.M., Fontaneto, D. \& Worsaae, K. (2017) Genetic Spatial Structure of an anchialine cave annelid indicates connectivity within - but not between - islands of the Great Bahamas Bank. Molecular Phylogenetics and Evolution, 109, 259-270.

Hart Jr., C.W., Manning, R.B. \& Iliffe, T.M. (1985) The fauna of Atlantic marine caves: evidence of dispersal by sea floor spreading while maintaining ties to deep waters. Proceedings of the Biological Society of Washington, 98 (1), 288-292. 
Hart, C. \& Manning, R.B. (1981) The Cavernicolous Caridean Shrimps of Bermuda (Alpheidae, Hippolytidae, and Atyidae). Journal of Crustacean Biology, 1 (3), 441-456.

Hoban, S., Kelley, J.L., Lotterhos, K.E., Antolin, M.F., Bradburd, G., Lowry, D.B., Poss, M.L., Reed, L.K., Storfer, A. \& Whitlock, M.C. (2016) Find the genomic basis of local adaptation: Pitfalls, practical solutions, and future directions. The American Naturalist, 188(4), 379-397.

Hobbs, H.H. III (1978) The female of Barbouria cubensis (Von Martens) (Decapoda, Hippolytidae) with notes on a population in the Bahamas. Crustaceana, 35, 99102.

Hobbs, H.H., Hobbs, H.H. \& Daniel, M.A. (1977) A Review of the Troglobitic Decapod Crustaceans of the Americas. Smithsonian Contributions to Zoology, 244, 1-183.

Holthuis, L. (1973) Caridean Shrimps Found in Land-locked Saltwater Pools at Four Indo-West Pacific Localities (Sinai Peninsula, Funafuti Atoll, Maui and Hawaii Islands): with the Description of One New Genus and Four New Species. Zoologische Verhandelingen, 128, 3-48.

Holthuis, L.B. (1963) On Red Coloured Shrimps (Decapoda, Caridea) from Tropical Land-Locked Saltwater Pools. Zoologische mededelingen, 38 (16), 261-179.

Humphreys, W.F., Watts, C.H.S., Cooper, S.J.B \& Leijs, R. (2009) Groundwater estuaries of salt lakes: buried pools of endemic biodiversity on the western plateau, Australia, Hydrobiologia, 626, 79-95.

Iliffe, T.M. \& Kornicker, L.S. (2009) Worldwide diving discoveries of living fossil animals from the depths of anchialine and marine caves. Smithsonian Contributions to Marine Sciences, 38, 269-280.

Iliffe, T.M. (2005) Anchialine Caves Biodiversity. In: Culver, D.C. \& White, W.B. (Ed.), Encyclopedia of Caves. Elsevier, Burlington, MA, pp. 24-30.

Iliffe, T.M., (2002) Conservation of anchialine cave biodiversity. In: Proceedings of the Symposium Karst Frontiers, 7, 99-102.

Iliffe, T.M. (2000) Anchialine Cave Ecology. In: Wilkens, H., Culver, D.C. \& Humphreys, W.F. (Ed.), Ecosystems of the World. 30. Subterranean Ecosystems. Elsevier Science, Amsterdam, pp. 59-76.

Iliffe, T.M., Jickells, T. \& Brewer, M. (1984) Organic pollution of an inland marine cave from Bermuda. Marine Environmental Research, 12, 173-189. 
Istace, B.A. Friedrich, L. d'Agata, S. Faye, E. Payen, O. Beluche, C. Caradec, S. Davidas, C. Cruaud, G. Liti, A. Lemainque, S. Engelen, P. Wincker, J. Schacherer \& J.-M. Aury. 2017. de novo assembly and population genomic survey of natural yeast isolates with the Oxford Nanopore MinION sequencer. GigaScience, 6(2), $1-13$.

Janser, H.J., M. Liem, S.A. Jong-Raadsen, S. Dufour, F.-A. Weltszien, W. Swinkels, A. Koelewijn, A.P. Palstra, B. Pelster, H.P. Spaink, G.E. Van den Thillart, R.P. Dirks \& C.V. Henkel. 2017. Rapid de novo assembly of the European eel genome from nanopore sequencing reads. Nature Scientific Reports, 7, 7213.

Kano, Y. \& Kase, T. (2004) Genetic exchange between anchialine cave populations by means of larval dispersal: The case of a new gastropod species Neritilia cavernicola. Zoologica Scripta, 33 (5), 423-437.

Katoh, K., Misawa, K., Kuma, K. \& Miyata, T. (2002) MAFFT: a novel morthod for rapid multiple sequence alignment based on fast Fourier transform. Nucleic Acids Research, 30, 3059-3066.

Lacy, R.C. \& Alaks, G. (2012) Effects of inbreeding on skeletal size and fluctuating asymmetry of Peromyscus polionotus mice. Zoo Biology, 32 (2), 125-133.

Li, Y., Wang, W., Liu, X., Zhang, J. \& Gul, Y. (2011) DNA extraction from crayfish exoskeleton. Indian Journal of Experimental Biology, 49, 953-957.

Li H. \& Durbin, R. (2009) Fast and accurate short read alignment with Burrows-Wheeler transform. Bioinformatics, 25(14), 1754-60.

Martin, C.H. \& Wainwright, P.C. (2013) Multiple fitness peaks on the adaptive landscape drive adaptive radiation in the wild. Science, 339, 208-11.

Manning, R.B. \& Hart, C.W. (1984) The status of the Hippolytid shrimp genera Barbouria and Ligur (Crustacea: Decapoda): A Reevaluation. Proceedings of the Biological Society of Washington, 97, 655-665.

Martens, E., von (1872) Über cubanische Crustaceen nach den Sammlungen Dr. J. Gundlach's. Archiv für Naturgeschichte, 38 (1), 77-147, Plates 4-5.

McCormack, J.E., Hird, S.M., Zellmer, A.J., Carstens, B.C. \& Brumfield, R.T (2013) Application of next-generation sequencing to phylogeography and phylogenetics. Molecular Phylogenetics and Evolution, 66(2), 526-538.

McMillan, A.M., Bagley, M.J., Jackson, S.A. \& Nacci, D.E. (2006) Genetic diversity and structure of an estuarine fish (Fundulus heteroclitus) indigenous to sites associated with a highly contaminated urban harbor. Ecotoxicology, 15, 539-548. 
Mejía, L.M., Zarza, E. \& López, M. (2008) Barbouria yanezi sp. nov., a new species of cave shrimp (Decapoda, Barbouriidae) from Cozumel Island, Mexico. Crustaceana, 81 (6), 663-672.

Mylroie, J.E. \& Mylroie, J.R. (2011) Void development on carbonate coasts: creation of anchialine habitats. Hydrobiologia, 677(1), 15-32.

Mylroie, J.E. \& Carew, J.L. (2003) Karst development on carbonate islands. in: Budd D.A., Saller A.H. and Harris P.A. (Eds), 1995. Unconformities in Carbonate Strata - Their Recognition and the Significance of Associated Porosity, AAPG Memoir 63, 55-76.

O’Grady, J.J., Brook, B.W., Reed, D.H., Ballou, J.D., Tonkyn, D.W. \& Frankham, R. (2006) Realistic levels of inbreeding depression strongly affect extinction risk in wild populations. Biological Conservation, 133 (1), 42-51.

Oha, T. \& Paal, J. (2004) Multivariate analysis of morphological variation among closely related species Bromus Japonicus, B. squarrosus and B. arvensis (Paceae) in comparison with isozyme evidence. Nordic Journal of Botany, 24 (6), 691-702.

Onaga, H., Fiedler, G. \& Baeza, J. (2012) Protandric simultaneous hermaphroditism in Parhippolyte misticia (Clark, 1989) (Caridea: Hippolytidae): implications for the evolution of mixed sexual systems in. Journal of Crustacean Biology, 32(3), 383394.

Pérez-Moreno, J.L., Iliffe, T.M. \& Bracken-Grissom, H.D. (2016) Life in the Underworld: Anchialine cave biology in the era of speleogenomics. International Journal of Speleology, 45 (2), 149-170.

Peterson, B.K., Weber, J.N., Kay, E.H., Fisher, H.S. \& Hoekstra, H.E. (2012) Double digest RADseq: an inexpensive method for de novo SNP discovery and genotyping in model and non-model species. PLOS ONE, 7(5), e37135.

Porter M.L. 2007. Subterranean biogeography: what have we learned from molecular techniques. Journal of Cave and Karst Studies. 69(1):179-186.

Protas, M.E., Trontelj, P. \& Patel, N.H.N. (2011) Genetic basis of eye and pigment loss in the cave crustacean, Asellus aquaticus. Proceedings of the National Academy of Sciences of the United States of America, 108(14), 5702-5707.

Rafineque, C.S. (1815) Analyse de la Nature, ou Tableau de l'Univers et de Corps Organisés. Palermo, L'Imprimerie de Jean Barravecchia. 224 pp. 
Rathbun, M.J. (1912) Some Cuban Crustacea, with notes on the Astacidae by Walter Faxon, and a list of Isopoda, by Harriet Richardson. Bulletin of the Museum of Comparative Zoology, 54 (15), 451-460, Plates 1-5.

Reddy, P.A., Cushman, S.A., Srivastava, Sarkar, M.S. \& Shivaji, S. (2017) Tiger abundance and gene flow in Central India are driven by disparate combinations of topography and land cover. Diversity and Distributions, 23, 863-874.

Rose, E., Masonjones, H.D. \& Jones, A.G. (2016) A DNA-based assessment of the phylogenetic position of a morphologically distinct, anchialine-lake-restricted seahorse. Journal of Heredity, 107, 553-558.

Russ, A., Santos, S.R. \& Muir, C. (2010) Genetic population structure of an anchialine shrimp, Metabetaeus lohena (Crustacea: Alpheidae), in the Hawaiian Islands. Revista de Biologia Tropical, 58(1), 159-170.

Santos, S.R. (2006) Patterns of genetic connectivity among anchialine habitats: a case study of the endemic Hawaiian shrimp Halocaridina rubra on the island of Hawaii. Molecular Ecology, 15, 2699-2718.

Schawbe, S.J., Cathcart, E.M. \& Carew, J.L. (2010) Elevated levels of heavy metals detected in mordern soils and flooded-cave sediment from the Bahamas. In: Proceedings of the 14th Symposium on the Geology of the Bahamas and other Carbonate Regions, pp. 209-219.

Sket, B. (2005) Anchialine Caves. In: Culver, D.C. \& White, W.B. (Ed.). Encyclopedia of Caves. Elsevier Academic Press, 30-37.

Sket, B. (1999) The nature of biodiversity in hypogean waters and how it is endangered. Biodiversity and Conservation, 8(10), 1319-1338.

Stock, J.H. (1986) The concept "anchialine” reconsidered. Stygologia, 2, 90-92.

Tan, M.H., C.M. Austin, M.P. Hammer, Y.P. Lee, L.J. Croft \& H.M. Gan. 2017. Finding Nemo: Hybrid assembly with Oxford Nanopore and Illumina reads greatly improves the Clownfish (Amphiprion ocellaris) genome assembly. GigaScience, gix137.

Tigano, A., Shultz, A.J., Edwards, S.V., Robertson, G.J. \& Friesen, V.L. (2017) Outlier analyses to test for local adaptation to breeding grounds in a migratory arctic seabird. Ecology and Evolution, 7, 2370-2381.

Timm, L. \& Bracken-Grissom H.D. (2015) The forest for the trees: Evaluating molecular phylogenies with an emphasis on higher-level Decapoda. Journal of Crustacean Biology, 35(5), 577-592. 
Turner, B.J., Duvernell, D.D., Blunt, T.M. \& Barton, M.G. 2008. Reproductive isolation among endemic pupfishes (Cyprinodon) on San Salvador Island, Bahamas:

microsatellite evidence. Biological Journal of the Linnean Society. 95: 566-582.

Weese, D.A., Fujita, Y. \& Santos, S.R. (2013) Multiple colonizations lead to cryptic biodiversity in an island ecosystem: Comparative phylogeography of anchialine shrimp species in the Ryukyu Archipelago, Japan. Biological Bulletin, 225, 24 41.

Wicksten, M.K. (1996) Parhippolye cavernicola, new species (Decapoda: Caridea: Hippolytidae) from the Tropical Eastern Pacific, with taxonomic remarks on the genera Somersiella and Koror. Journal of Crustacean Biology, 16 (1), 201-207.

Wilson, E.O. (1985) The biological diversity crisis. BioScience, 35(11), 700-706 
CHAPTER II

WIDESPREAD PHENOTYPIC HYPERVARIATION IN THE ENIGMATIC ANCHIALINE SHRIMP BARBOURIA CUBENSIS (DECAPODA: BARBOURIIDAE) 


\begin{abstract}
Classification and evolutionary relationships among anchialine shrimp from the family Barbouriidae Christoffersen, 1987, has long been a topic of debate amongst crustacean taxonomists. To date, no study has examined morphological or molecular variation among populations of these enigmatic shrimp. The present study documents and analyzes patterns of widespread morphological variation within populations of Barbouria cubensis von Martens, 1872, from anchialine pools on three Bahamian islands. Such extensive morphological variation confounds identification using classic taxonomical methods. Phenotypic variation is by no means a new topic, but studies of decapods are typically limited to isolated individuals or few morphological characters. Moreover, past studies of B. cubensis do not report extensive morphological variation, however we find that upwards of $90 \%$ of individuals are affected. Anomalous phenotypes are described in 54 morphological characters with no detectable pattern associated with geographic distribution. The term phenotypic hypervariation (PhyV) is used to describe morphological variation that greatly deviates from any previous taxonomic descriptions. Analysis of partial sequences of the $16 \mathrm{~S}$ and COI mitochondrial genes confirm the identity of morphologically variable specimens as a single species (B. cubensis) without population structure across the tropical western Atlantic. The lack of genetic variation within proposed populations of B. cubensis suggests PhyV is not correlated with cryptic diversity. Morphological variation at this scale likely depends on recent changes either to their environment or genetic diversity.
\end{abstract}




\section{INTRODUCTION}

A common feature among many tropical islands in the tropical western Atlantic is the presence of seemingly disjointed anchialine pools, which are subterranean estuaries influenced by tidal flow (Stock, 1986; Bishop et al., 2015; Pérez-Moreno et al., 2016). Subsurface tidal flows can be strong enough to permit marine conditions in the landlocked pools via seawater exchange through conduits created by the dissolution of the underlying carbonate platform (Edwards, 1996; Mylroie \& Carew, 2003). However, biological connectivity and diversity is largely restricted, which has led to the "ecological islands within islands" hypothesis (Edwards, 1996; Pérez-Moreno et al., 2016). Most physical connections between anchialine pools and the surrounding ocean remain unexplored and form extensive spatially complex subterranean networks (Becking et al., 2011; Mylroie \& Mylroie, 2011; Bishop et al., 2015). The biota found within these pools is often rare and endemic, with crustaceans representing over $80 \%$ of animal biodiversity in these systems (Iliffe, 2000; Iliffe, 2005; Sket, 2005; Iliffe; 2009). Among anchialine pool inhabitants is a group of enigmatic caridean shrimp from the family Barbouriidae that live within the caves and pools (Manning \& Hart, 1984; De Grave et al., 2009). Barbouriid shrimps are described as having a tethyan distribution pattern along tropical latitudes, mostly confined to land locked pools (Manning \& Hart, 1984). The family Barbouriidae Rafineque, 1815 is comprised of Barbouria Rathbun, 1912, Parhippolyte Borradaile, 1900, Janicea Manning \& Hart, 1984 and Calliasmata Holthuis, 1973, which contain a total of 11 species. Until the recent reclassification of Calliasmata (De Grave et al., 2014), Barbouriidae was united by the presence of a unique subocular tooth on the carapace (Manning \& Hart, 1984; Clark, 1989; Chace, 1997). Additionally, these shrimps 
are described as having a mandible with a 3-jointed palp lacking incisor process, long slender pereiopods, the first two pairs chelate with a multiarticulated carpus and merus, and an appendix masculina shorter or subequal to the length of the appendix interna on the endopod of the $2^{\text {nd }}$ pleopod in males (Chace, 1972; Manning \& Hart 1984;

Christoffersen, 1987). Characters used to discriminate among members of Barbouriidae include; width of the cornea relative to the eyestalk, ratio of the length versus the width of the scaphocerite, teeth of the rostrum, arrangement of arthrobranchs and podobranchs, subdivision of the articles of pereiopods three to five, ratio of the rostrum length versus height, number of setae of the appendix masculina, and shape of the terminal margin of the telson (Chace, 1972; Manning \& Hart, 1984; Wicksten, 1996; Mejía et al., 2008).

Barbouria cubensis is a common species found within anchialine pools throughout the tropical western Atlantic ranging from Bermuda, the Bahamas, Turks and Caicos, Cayman Brac and the Yucatán Peninsula of Mexico (Mejía et al., 2008). Species within the genus Barbouria can most notably be identified by the presence of darkly pigmented cornea that are narrower than the eyestalk, and the lack of subdivision of the articles of pereiopods three to five (Fig. 1) (Chace, 1972; Manning \& Hart 1984). Previous records have documented minor morphological variation for B. cubensis but are limited to the length and teeth of the rostrum, ratio of length versus width of the scaphocerite, number of subdivisions of the articles of the second pereiopod, length and spination of the appendix masculina and the body size (Rathbun, 1912; Holthuis, 1963; Chace, 1972; Hobbs et al., 1977; Hobbs, 1978; Hart \& Manning, 1981; Manning \& Hart, 1984; Mejía et al., 2008). However, recent examination of B. cubensis from anchialine pools on the Bahamian islands of Abaco, Eleuthera and San Salvador from 2012-2015 
has revealed a wide range of morphological variation in these previously documented characters (Rathbun, 1912; Holthuis, 1963; Chace, 1972; Hobbs et al., 1977; Hobbs, 1978; Hart \& Manning, 1981; Manning \& Hart, 1984; Mejía et al., 2008), but also extends to an additional 50 morphological characters. For the purposes of this manuscript, we use the term phenotypic hypervariation (PhyV) to describe the morphological variation that deviates from previous taxonomic descriptions of $B$. cubensis (Rathbun, 1912; Holthuis, 1963; Chace, 1972; Hobbs et al., 1977; Hobbs, 1978; Hart \& Manning, 1981; Manning \& Hart, 1984; Mejía et al., 2008). To have a comparative framework for describing variation, we have defined "normal" to include all previous descriptions of morphological variation.

Molecular methods can be used to delimitate species, especially when the use of traditional taxonomic methods is not possible (Monaghan et al., 2005; Clare et al., 2007; Raupach et al., 2010). This can be particularly useful for B. cubensis as PhyV confounds traditional methods of identification. In recent years, several studies have shown the benefit of using molecular methods when cryptic species complexes exist with extensive phenotypic variation (Lefébure et al., 2007; Steinauer et al., 2007; Trontelj et al., 2009; Neiber et al., 2012; Weese et al., 2012; Cornils \& Held, 2014). With molecular barcoding it is possible to identify specimens exhibiting PhyV and determine if PhyV is the result of cryptic diversification.

The objective of this study is to document PhyV exhibited by B. cubensis collected from three Bahamian islands, and to determine if PhyV is associated with geographic distribution or cryptic genetic diversity. Timely documentation of this species is imperative, as rapid human development, pollution and continued natural disturbances 
(i.e., hurricanes) of tropical coastal areas is a formidable threat to these critically endangered animals. Fundamental studies of biodiversity are still needed to adequately protect endemic anchialine organisms.

\section{METHODS}

\section{SAMPLE COLLECTION}

Between June of 2012 and July 2015, 363 shrimps were collected from 25 anchialine pools on San Salvador, Bahamas (Fig. 2a). Suitable habitats were identified from previous records, Google Earth and information provided by island residents. Samples from this island were collected with hand nets or by baited minnow trap. For sites where conduits could not be located from land, snorkeling was utilized to locate the conduits and place minnow traps. In addition to the collection on San Salvador, 41 specimens from Abaco were donated by Dr. Craig Layman from three anchialine pools to the south of Little Harbour (Fig. 2b). Ninety-five specimens from Eleuthera were donated by Dr. Jocelyn Curtis-Quick from six anchialine pools distributed across the entire island (Fig. 2c). Tissue samples from Mayaguana, Bahamas and Mexican specimens were donated by Dr. Darryl L. Felder and Dr. Tom Iliffe respectively. A maximum of 30 shrimp were retained from each site per sampling effort. A total of 529 shrimp were examined for this study, however 463 were included in the final morphological analysis. Datum collected from 65 individuals determined to be juveniles, too heavily damaged or identified as Parhippolyte sterreri were excluded from analyses. Most individuals could not be identified to Barbouria cubensis based on taxonomic keys, however individuals were confirmed using DNA barcoding techniques. Specimens are deposited at the Oxford 
University Museum of Natural History Zoology Collection (OUMNH.ZC) and the Florida International Crustacean Collection (FICC). Specimens archived within the FICC are cataloged with the prefix HBG.

\section{MorPHOLOGiCAl Data COLLECTION}

Fifty-four morphological characters were examined to document the extent of morphological variation in specimens collected from the Bahamas (see appendix, Tables AI-III). Initially, 14 morphological characters were chosen for examination because they represent common diagnostic characters in caridean taxonomy (Hobbs et al., 1977; Hobbs, 1978; Manning \& Hart 1984; Chace, 1996; Bauer, 2004; De Grave et al., 2014). These include: three carapace characters, three rostral characters, two eye characters, three telson characters and three pereiopod characters (Fig. 2). The presence of gills and exopods of the maxillipeds and pereiopods were excluded in analyses because of inconsistency among previous records (Christoffersen, 1987; Wicksten, 1996). After PhyV was found during preliminary examinations of diagnostic characters, 13 additional characters believed to be conserved among carideans were included based on the advice of caridean taxonomic experts, Drs. Sammy de Grave and Raymond Bauer. These characters include five pereiopod characters, two pleopod characters and six mouthpart characters. Twenty-seven additional characters diagnostic to the family Barbouriidae sensu lato were examined to document the extent of family and species-specific morphological variations across individuals (Rathbun, 1912; Chace, 1972; Hart \& Manning, 1981; Manning \& Hart, 1984; de Grave et al., 2014). Lastly, the presence and position of sensory dorsal organs (SDO) were examined as they are believed to be present 
in some form in most crustaceans (Laverack et al., 1996; Laverack \& Macmillan, 1999; Lerosey-Aubril \& Meyer, 2013). Although the ultrastructure and function of SDOs can only be examined with the use of scanning electron microscopy (SEM) and histology their presence and external aspects can easily be found and described (Brandt, 1988; Lerosey-Aubril \& Meyer, 2013). This character was examined for its potential as a new diagnostic character for the family Barbouriidae due to the recent reclassification of the genus Calliasmata, which lacks characters considered as synapomorphies for barbouriid shrimps (de Grave et al., 2014).

\section{MorPhOlOGiCAl Data PRocessing}

Unweighted Pair Group Method with Arithmetic Mean (UPGMA) was conducted to determine if there is any pattern in the distribution of PhyV across Abaco, Eleuthera and San Salvador, Bahamas. For the purposes of this manuscript we define the expected phenotype of $B$. cubensis to include the combination of all previous morphological descriptions (Rathbun, 1912; Holthuis, 1963; Chace, 1972; Hobbs et al., 1977; Hobbs, 1978; Hart \& Manning, 1981; Manning \& Hart, 1984; Mejía et al., 2008). Qualitative characters (see appendix, Tables A1-3) were coded for analysis, as follows: character states matching previous descriptions of $B$. cubensis were coded as 1 and characters states not matching B. cubensis were coded as 2 . Values were selected to prevent artificial bias. Subset \#1 was generated to maximize the number of individuals included in analyses, using data for 25 characters that was collected for all 463 specimens (see appendix, Table A1). Subset \#2 was generated to maximize the number of characters included in analyses, using data for 50 characters for 121 specimens (see appendix, Table A2). Subset \#3 was 
generated to compare examine sexual dimorphism (see appendix, Table A3). All subsets included individuals from Abaco, Eleuthera and San Salvador, Bahamas. Data collected on the relative lengths of the segments of the antennule peduncle and pereiopods was excluded, because the diagnosed states are estimated measures. Data on the arrangement of the gill complement was deemed unreliable to establish the expected state for $B$. cubensis and was also excluded due to inconsistencies in previous records and the possibility of inaccuracy due to damage (Christoffersen, 1987; Wicksten, 1996).

Normality of data was tested using the Shapiro-Wilk statistics in R version 3.3.1 (R Core Team, 2016). Where necessary, values were normalized using logtransformation (Brian, et al., 2006). Values for each character were averaged by locality to avoid any bias resulting from the differences in samples size (Baltanás, et al., 2002).

Individuals were grouped by Longitude. A UPGMA tree was constructed using Euclidean distance between rows with 1000 bootstraps in SPSS ver. 22 (IBM, Armonk, NY). Based on the results of the UPGMA, no further analyses were conducted.

\section{MoleCUlar Data COLLECTiON}

To investigate the presence of cryptic speciation across the Bahamas, molecular data was collected from 69 specimens of Barbouria cubensis. Sampling localities on San Salvador Island were grouped into seven regions based on geographic distance and topographic features separating each region. Six individuals were randomly selected from each region, with the criteria individuals from each sampling site were included and that half of the individuals exhibit PhyV to ensure diversity. Two specimens were randomly selected from each sampling locality from Abaco and Eleuthera. Tissue was collected 
using non-destructive methods to preserve specimen integrity, and preserved in $95-100 \%$ $\mathrm{EtOH}$ and stored at $-20^{\circ} \mathrm{C}$. All tissue samples from Mayaguana, Bahamas and the Yucatán Peninsula of Mexico were included. Additional sequences were acquired from GenBank.

Total genomic DNA was extracted from muscle tissue of the abdomen, antennule or the $3^{\text {rd }}$ to $5^{\text {th }}$ pleopod using DNeasy® Blood and Tissue Kits (Qiagen, Valencia, CA). For incomplete tissue digestions, $10 \mu \mathrm{l}$ of $10 \%$ DTT and $10 \mu$ Proteinase K was added, and samples were incubated until complete digestion was achieved. Total genomic DNA quality was visualized using $2 \%$ agarose gels and concentration was measured using the Qubit dsDNA HS Assay kit on the Qubit 2.0 Fluorometer (Invitrogen, Life Technologies, CA) according to manufacturer's instructions.

Two partial mitochondrial genes were selected for their utility in decapod studies of identification (DNA barcoding), genetic diversity, and phylogeny (Bracken et al., 2009; Beaza, 2013; De Grave et al., 2014; Aznar et al., 2015). The mitochondrial genes included the 16S large ribosomal subunit ( $\sim 550$ basepairs (bps)) and protein-coding cytochrome oxidase I ( $\sim 600$ bps, COI). The large ribosomal subunit (16S) was amplified with primers 16S-1471/1472 (Palumbi et al., 1991; Crandall \& Fitzpatrick 1996), COI was amplified with primers F/10, or LCO1490/HCO2198 (Folmer et al., 1994; Bracken-Grissom et al., 2014). Amplification was performed in $25 \mu \mathrm{l}$ volume reactions containing $12.5 \mu \mathrm{l}$ GoTaq DNA Polymerase (Promega, Madison, WI), $1 \mu \mathrm{l}$ forward and reverse primer for each gene, $9.5 \mu 1$ sterile $\mathrm{H}_{2} \mathrm{O}$ and $1 \mu 1$ template DNA. The thermal cycling profile conformed to the following parameters: Initial denaturation for $5 \mathrm{~min}$ at $95^{\circ} \mathrm{C}$ followed by 35 cycles of 30 secs at $94^{\circ} \mathrm{C}, 45 \operatorname{secs}$ at $48-56^{\circ} \mathrm{C}, 45 \operatorname{secs}$ at $72^{\circ} \mathrm{C}$ and a final extension of 5 min at $72^{\circ} \mathrm{C}$. PCR products were sent to GENEWIZ for amplicon purification and subsequent 
sequencing (South Plainfield, NJ,). All sequencing data was visually inspected, quality trimmed, manually cleaned and assembled using Geneious 9.1.7 (Biomatters Ltd., Newark, NJ). Once assembled, sequences were aligned using MAFFT v7.308 (Katoh \& Standley, 2013). To identify potential pseudogenes, we translated protein-coding sequences and checked for insertions and deletions, stop codons and identified the open reading frames, and compared sequences among conspecifics following the protocol of Song et al. (2008).

\section{Phylogenetic ANALYSES}

Individual gene trees for $16 \mathrm{~S}$ and COI were constructed alongside a concatenated dataset of 16S and COI sequences to investigate cryptic diversity in Barbouria cubensis (Table 1). Missing data were designated as a “?” in our alignment. To improve resolution, both genes were concatenated into a single alignment and partitioned by gene (Ahyong \& O’Meally, 2004; Porter et al., 2005; Robles et al., 2007; Page et al., 2008). We conducted a partition test of heterogeneity and incongruence length difference test to determine if the gene regions were appropriate to combine for analyses, as implemented in PartitionFinder 2.7.1 and PAUP* respectively (Swofford, 2002; Lanfear et al., 2016). The model of evolution that best fit the individual data genes was determined by Partitionfinder 2.7.1. Independent models of evolution and parameters were partitioned in the Bayesian concatenated analysis.

The Maximum Likelihood (ML) analyses were conducted using RAxML 7.2.8 (Randomized Accelerated Maximum Likelihood, Stamatakis, 2014) with computations performed on the high-performance computing cluster at Florida International University. 
Likelihood settings followed the General Time Reversible Model (GTR) with a gamma distribution and RAxML estimated all free parameters. Confidence in the resulting topologies was assessed using Rapid Bootstrapping and a search for the best-scoring tree with 1000 replicates (Felsenstein, 1996). Bayesian Inference (BI) analyses were performed using parameters selected by PartitionFinder 2.7.1 and conducted in MrBayes v3.2.6 (Huelsenbeck \& Ronquist, 2001). A MCMC algorithm ran for 10,000,000 generations, sampling 1 tree every 1000 generations. Observation of likelihood scores allowed us to determine burn-ins and stationary distributions. Once split frequency in the Bayesian analysis reached $<0.01$ a $50 \%$ majority-rule consensus tree was obtained from the remaining trees. Posterior probabilities for clades were compared for congruence between analyses, Bootstrap values $>70$ for RAxML and $>0.90$ for Bayesian are presented on the phylograms.

\section{RESULTS}

Over $90 \%$ of the 463 B. cubensis examined exhibit morphological variation beyond previous descriptions in one or more characters. PhyV exhibited in these shrimps often falls outside of characters prescribed to any genus of Barbouriidae or members of superfamily Alpheoidea (Table 1, Fig. 3: a-x). PhyV is present in individuals from all 34 localities sampled across Abaco, Eleuthera and San Salvador, Bahamas. 


\section{DIAGNOSIS OF PHENOTYPIC HYPERVARIATION IN BARBOURIA CUBENSIS}

CARAPACE. Carapace is smooth; in some cases, a strong protuberance laterally or lateral grooves originating from the cardiac region are present (Fig. 3: f, g \& 1). While in most individuals the dorsal margin of the carapace forms a gradual rounded slope from the postorbital margin to the posterior margin, in some individuals the dorsal margin forms a distinct hump (see appendix, Fig. A1: a-c). Antennal and branchiostegal teeth are present in most specimens, but either could be absent. Some specimens lacking teeth the carina is present and multiple teeth originate from the carapace margin anterior to the carina (see appendix, Fig. A1: d-e). Approximately 18\% (n=463) of individuals do not match previous descriptions of B. cubensis for these characters. Additionally, all specimens have at least two sensory dorsal organs (SDO) situated dorsally along the carapace (Lerosey-Aubril \& Meyer, 2013). The first is allied posteriorly with the epigastric tooth and is present even when the epigastric tooth is absent. The second is medially situated along the dorsal margin of the carapace within the cardiac region and may have a smaller pair juxtapose and slightly posterior to the larger SDO (see appendix, Fig. A1: $\mathrm{g}-\mathrm{i})$.

ROSTRUM. Rostrum slender, typically reaching the middle of the second article of the antenullar peduncle. However, it was common for the rostrum to be absent (Fig. 3: b, c \& f), not reaching beyond the first article of the antenullar peduncle or the eyestalk (Fig. 3: g) or reaching past the distal end of the second article (Fig. 3: d). The rostrum bears 4-7 total dorsal teeth, 3-4 along the postorbital margin, and 1-7 ventral teeth. However, the rostrum bears $0-15$ dorsal $(0-10$ postorbital) and $0-8$ ventral teeth. 
Additionally, in some individuals the rostrum can have bifurcated spines, or is bifid or trifid (Fig. 3: c, g \& h). Over 51\% (n=463) of individuals exhibit character states inconsistent with the diagnosis of $B$. cubensis.

EYES. The eyes often have well-developed cornea that are narrower than the eyestalk (Manning \& Hart, 1984). However, eyes with greatly reduced or absent pigmentation are present in some individuals (Fig. 3: j), or in some instances the cornea was subequal to or broader than the eyestalk (Fig. 3: 1). Frequently a medial spine or tubercle is present along the interior margin of the eyestalk (Fig. 3: j \& k). Just over 26\% $(n=463)$ of specimens exhibiting character states that are not prescribed to any species within Barbouriidae (see appendix, Fig. A1: j-1).

SCAPHOCERITE. The scaphocerite on average is approximately 3.1 times as long as wide. Some individuals exhibit lateral compressions in the anterior third of the scaphocerite (refer to appendix, Fig. A2: a), or exhibit asymmetry between the left and right scale. The length versus width ratio of approximately $66 \%(n=121)$ of individuals is greater than previously reported for species of Barbouria.

MOUTH PARTS. Variation was present in the maxilla and maxillipeds, predominantly in the shape of the caridean lobe. Epipods are present on the third maxillipeds. The distal margin of the epipods terminated in a single hook, or between two and four juxtaposed hooks. In some specimens a reduced incisor appeared to be present, but it could not be determined if the structure was a true incisor process. Variation was 
also observed in the gill complements. However, this variation is not reported here due to inconsistent results and the possibility of inaccuracy due to damage.

PEREIOPODS. Pereiopods 1 and 2 chelate, but the finger may be shorter or longer than, or equal to the length of the palm. Additionally, the interior margins of the chelae may be straight or curved, and either strongly serrated or smooth. Pereiopod 2 exhibits a wide range of articulation from the ischium with $0-8$ subdivisions, merus with $8-20$ subdivisions and carpus with 20-40 subdivisions (refer to appendix, Fig. A2: b \& c). The posterior 3 pairs of pereiopods are undivided but exhibit a wide range of spines running medially along the posterior margin. Spines may be absent or reduced to well-developed occurring either as pairs or alternating along the length of the segment. Epipods were present on the anterior four pereiopods, bearing between 1-4 hooks in varying positions similar to those on the third maxillipeds. Of the individuals in which pereiopods were examined, nearly all exhibit character states not assigned to B. cubensis.

ABDOMINAL PLEURA. The abdominal pleura of the somites typically match the previous descriptions (Manning \& Hart 1984). It was found that for some specimens the first pleura may or may not overlap the carapace of the cephalothorax, and the first or third pleura may overlap the second (Fig. 3: n \& p). The anterior three pleura may be square or have abnormal dentation along the margins (Fig. 3: n \& p). In some instances, the pleura exhibit folding and can protrude laterally away from the abdomen (Fig. 3: o) similar to the findings of Fernandes et al. (2011). The fourth abdominal pleura ranged from obtusely to acutely round, or the posteroventral corner may be produced into a small 
spine or tooth. The fifth and sixth abdominal pleura could lack spines (Fig. 3: n) or be produced into multiple small spines or teeth. Nearly $29 \%(\mathrm{n}=463)$ of specimens exhibiting abnormalities in the pleura of the abdominal somites not described for any species within Barbouriidae.

PLEOPODS. The endopod of the male exhibits an appendix masculina that may be shorter by two-thirds or longer than the appendix interna and bearing 5-16 terminal setae arranged in a ring. Of the 140 individuals in which endopods were examined, 66 individuals were identified as male. Approximately $93 \%$ of male endopods exhibit character states outside of variation prescribed to B. cubensis.

TELSON. The telson ranged in shape from very slender and elongate, reaching well beyond the posterior margin of the uropods, to being short and stout not reaching beyond the posterior margin of the uropods (Fig. 3: r). Among many individuals with an elongate telson, the posterior third of the telson is laterally compressed (Fig 3B: v). Among individuals with an abnormally short telson, within the anterior third the telson becomes dorsoventrally compressed (Fig. 3: r). Alternatively, some individuals exhibit a telson with the medial third wider than the anterior and posterior third (Fig. 3: s) or could have a telson that is bifid (Fig. 3: t) or with a cavity anterior to the posterior margin (Fig. 3: x). The telson may bear 0-13 dorsal spines, and 0-23 terminal spines. Telson spines may be paired or unpaired. The terminal margin of the telson ranges in shape from being flat (Fig. 3: v) to pointed with an apical spine or tooth. The telson of $70 \%(n=463)$ of individuals could not be assigned as matching that of B. cubensis. 
UROPODS. Exopods of the uropods are armed with 0-2 posterolateral teeth. It was found that few specimens possess additional teeth medially along the lateral margin of the exopod, or that the lateral margin may be straight or exhibit multiple curves.

\section{DATA ANALYSIS}

Statistical analyses were conducted to test the hypothesis that the distribution of phenotypic hypervariation is correlated with geographic location. All characters exhibit a normal distribution based on Shapiro-Wilk test. PhyV is present in specimens from Abaco, Eleuthera and San Salvador, Bahamas. No clustering or discernable distribution of PhyV is detected under all parameters in which UPGMA was conducted (Fig. 4).

\section{CRYPTIC DIVERSITY}

The combined $16 \mathrm{~S}$ and COI tree included 70 individuals of B. cubensis as the ingroup taxa (Fig. 5). The species, Parhippolyte misticia, Parhippolyte sterreri, Parhippolyte uveae and Janicea antiguensis from the family Barbouriidae and Lysmata amboinensis from the family Lysmatidae were included as the outgroup taxa. For this dataset, 144 new sequences were generated including 72 new sequences for $16 \mathrm{~S}$, and 72 new sequences for COI (Table 2). Individual gene trees were without conflicting topologies. Results provided no support for cryptic speciation among B. cubensis (Fig. 5). Individuals identified as $B$. cubensis from all localities form a single polytomy, and we find no evidence for population structure across localities. All individuals in this data set that grouped with $B$. 
cubensis included a wide range of PhyV, and no patterns relating to morphological variation were detected.

\section{DISCUSSION}

\section{EXTENT OF PHENOTYPIC VARIATION IN BARBOURIA CUBENSIS.}

Examples of phenotypic variation are abundant in the animal kingdom (Allegue et $a l ., 2017)$; however, the rate and extent of variation we report has never been documented in crustaceans (Agnalt et al., 2013). Examples of "abnormal” morphologies of decapods have been reported in crabs, crayfish, penaeid prawns, and Palaemon shrimp (Béguer et al., 2008; Duarte et al., 2008). Reported abnormalities include: duplication and asymmetry of chelae, bifurcation of rostrum and telson, rostrum size, curve and tooth number or absence of rostrum, reversal of asymmetry, abnormal sexual appendages, carapace spines, pereiopods, backwards folding and abnormal positioning of the abdominal epimera, and deformed telson and uropods (Aguirre \& Hendrickx, 2005; Béguer et al., 2008; Duarte et al., 2008; Fernandes et al., 2011). These records are not comparable to the morphological variation we report in this study because they are limited to one or few individuals and are typically limited to a single morphological character (Aguirre \& Hendrickx, 2005; Béguer et al., 2008; Fernandes et al., 2011).

The 463 B. cubensis examined in this study represent a unique example of phenotypic hypervariation (PhyV). We define PhyV as morphological variation beyond the combined variation described in previous records of $B$. cubensis (Rathbun, 1912; Holthuis, 1963; Chace, 1972; Hobbs et al., 1977; Hobbs, 1978; Hart \& Manning, 1981; 
Manning \& Hart, 1984; Mejía et al., 2008). Less than 7.5\% ( $\mathrm{n}=463)$ of individuals are without PhyV and PhyV was present in all 54 characters examined in at least one individual. For each morphological character the frequency of PhyV present is between 6.9\% $(\mathrm{n}=463)$ to $95.5 \%(\mathrm{n}=121)$ of individuals. The presence of PhyV among shrimp sampled from Abaco, Eleuthera and San Salvador without any discernable pattern suggests PhyV is not associated with locality and is likely present among all populations of B. cubensis across the western Atlantic (Fig. 4).

Previous records indicate abnormal phenotypes typically occur at low rates in crustaceans (Béguer et al., 2008) with one notable example. The highest rate of "deformities" is reported at $40 \%(\mathrm{n}=1,578)$ and $58 \%(\mathrm{n}=539)$ of individuals in Palaemon longirostris, which is far less than the observed 90\% $(\mathrm{n}=463)$ in B. cubensis (Béguer et al., 2008; Béguer et al., 2010). Morphological "abnormalities" in P. longirostris is limited to four characters, which include cephalothorax anomalies, rostral "deformations" and pronounced bilateral dissymmetry of the scaphocerite and uropods (Béguer $e t a l$., 2008). The nature of morphological variations of $P$. longirostris appears similar to those of B. cubensis, however PhyV in B. cubensis extends to 54 morphological characters compared to the four of $P$. longirostris. As recently as 1984 , extensive variation has not been reported for $B$. cubensis by carcinologists, which includes records of specimens collected from localities sampled in this study (Hobbs, 1978; Manning \& Hart, 1984). Similar to P. longirostris, PhyV of B. cubensis has likely appeared within the past 30 to 40 years (Hart \& Manning, 1981; Manning \& Hart, 1984; Béguer et al., 2008). We do not believe that the appearance of PhyV is the result of increased sampling effort. Based on the numbers of specimens previously collected from sites included in this study if 
aberrant individuals were present at the time of those collections they would have been reported, especially considering the high rate at which we find PhyV is present in this study.

Many of the shrimp examined in this study exhibited characters synonymous with Barbouria cubensis, Barbouria yanezi, Parhippolyte sterreri or Janicea antiguensis and that are not described as being shared by the four species (i.e. terminal margin shape and spination of telson). Additionally, some specimens exhibited morphological characters not present in any shrimp within the family Barbouriidae (Fig. 3). It is important to consider revisiting and sampling other species of barbouriid shrimp in the western Atlantic to determine if $\mathrm{PhyV}$ is limited only to $B$. cubensis or if it is common among all species.

\section{Potential CAUSES OF PHENOTYPIC HyPERVARIATION}

It is possible that phenotypic hypervariation may represent cryptic diversification as reported in atyid shrimp, if island populations are effectively isolated. Caridina rubella is reported to exhibit regional morphological variation in the length of the rostrum as either long or short (Weese et al., 2012). The two morphotypes of $C$. rubella correspond to two genetically divergent populations with two discrete COI haplotype networks as the result of cryptic speciation. We feel this is not comparable as the morphological variation of $C$. rubella occurs in a single character correlated to locality and resulting from speciation. In our phylogenetic analysis we included several individuals that exhibited severe PhyV along those with the individuals matching the normal B. cubensis phenotype. We found all individuals to be genetically identical with no population 
structure attributed to morphological variation. Our findings provide some insight into the source of PhyV, as we can conclude that PhyV is not related to cryptic diversity.

Alternatively, PhyV may be caused by low genetic diversity due to severe inbreeding or population bottleneck, which can lead to an accumulation of deleterious mutations, increased expression of abnormal phenotypes and ultimately extinction (Creasey et al., 2000; Fumagalli et al., 2002, O'Grady et al., 2006; Lampert et al., 2007; Duarte et al., 2008; Lacy \& Alaks, 2012; Hedrick \& Garcia-Dorado, 2016). Highly connected island populations are capable of inbreeding when species exhibit strong dispersal capabilities Kano \& Kase, 2004; Santos, 2006; Russ et al., 2010). Previous records of B. cubensis only include two ovigerous females, in which abundant very small oocytes were found in the gonads (Hobbs, 1978). It is likely that these shrimps have extended planktonic development with strong dispersal capabilities similar to other caridean species that produce numerous small oocytes (Bauer, 2005; Russ et al., 2010; Weese et al., 2013). For anchialine organisms with planktotrophic larvae genetic connectivity occurring between populations has mostly been found to be limited to 600 km (Kano \& Kase, 2004; Santos, 2006; Russ et al., 2010; Weese et al., 2013; Gonzales et al., 2017). The shortest direct route between the Yucatan and the Bahamas is $>1200 \mathrm{~km}$, and the closest known population of B. cubensis to the Yucatan occurs $\sim 700 \mathrm{~km}$ away in the Cayman Islands. In this case we would expect highly connected populations within the Bahamas, distinct from the Yucatan population (Kano \& Kase, 2004; Santos, 2006; Russ et al., 2010; Weese et al., 2013; Gonzales et al., 2017). Distinct isolated clades of typhlatya are reported from the Yucatan and the Bahamian archipelago (Hunter et al., 2008). However, our phylogenetic analysis finds no population structure of $B$. cubensis 
suggesting genetic connectivity is high across localities (Fig. 5). If a recent population bottleneck reduced genetic diversity, inbreeding among highly connected populations could maintain low genetic diversity. It is possible the markers used in this study lack sufficient resolution to determine population level structure and patterns that exist between PhyV and genetic diversity. If the PhyV is due to low genetic diversity, then management efforts may be required to restore genetic diversity to these critically endangered populations.

Multiple species of Barbouriidae have been reported inhabiting the same localities (Hart \& Manning, 1981) and PhyV may indicate the presence of hybrid swarms due to interbreeding between these species (Wolf \& Mort, 1986; Perry et al., 2002; Cristescu et al., 2010; McInerney et al., 2014; Ribardière et al., 2017). Hybrid swarm is characterized by major morphological variation between individuals in populations with interbreeding hybrid individuals that back-cross with parent types (Cockayne \& Allan, 1926). The presence of intermediate character states between B. cubensis and P. sterreri, such as the terminal margin of the telson being pointed or nearly pointed and produced into a spine, and the number of spines on the postorbital margin of the rostrum support hybridization. Future studies using next generation sequencing techniques and fine-scale markers may provide further insights into the relationship between the abnormally rampant morphological variation and genetic diversity within Barbouriidae.

Deviations from perfect symmetry in bilaterally paired structures, or fluctuating asymmetry, may be used to evaluate developmental instability due to environmental factors, geographic location or as an indicator of environmental stress (Duarte et al., 2008; Maia et al., 2009; Klingenberg, 2015; Nishizaki et al., 2015). It is noteworthy that 
the presence of PhyV was commonly asymmetrical, especially in the situation of extra spines along the dorsal margin of the telson. However, most characters utilized in this study are either not paired structures (i.e., characters associated with the rostrum) or the PhyV expressed in paired structures were symmetrical (i.e., the number of subdivisions of segments of the second pereiopod). Due to the lack of geographic pattern in the distribution of PhyV and insufficient symmetry measures we were unable to assess fluctuating asymmetry.

The anchialine pools in which $B$. cubensis are found are known to have strong turbulent flows through a complex series of subterranean passages in the karst landmass (Bishop et al., 2015). Physical trauma during early development or following ecdysis can lead to extensive variation, possibly resulting from abrasion against the conduit walls due to strong tidal flows (Moncada \& Gomes, 1980; Bohonak, 1999; Giménez, 2006; Luppi \& Spivak, 2007; Follesa et al., 2008; Vogt et al., 2008). Similarly, damage due to parasitic infection can lead to abnormal phenotypes (Goodman \& Johnson, 2011).

Environmental factors such as salinity, $\mathrm{pH}$, temperature and contamination have been identified as causes of extensive variation in crustaceans (Smith \& Palmer, 1994; Stibor \& Lüning, 1994; Trussel, 1996; Trussel \& Smith, 2000; Agrawal, 2001; Kappes \& Sinsch, 2002; Chown et al., 2007; Ituarte et al., 2007; Reuschel \& Schubart, 2007; Béguer et al., 2008; Duarte et al., 2008; Béguer et al., 2010 Agnalt et al., 2013). Routine migration of B. cubensis in and out of anchialine pools (across the pycnocline) regularly exposes them to acute changes in temperature, $\mathrm{pH}$, salinity and dissolved oxygen levels (Bishop \& Iliffe, 2012). Because of this lifestyle and no prior record of extensive variation for $B$. cubensis, it is unlikely $\mathrm{PhyV}$ is due to salinity, $\mathrm{pH}$ or temperature. 
However, contamination such as lead remains a viable source of PhyV. If the source of PhyV has a non-genetic basis, then further study will be required to identify the source and implications for the conservation of endemic anchialine species in the western Atlantic.

\section{CONCLUSION}

We found that PhyV is present in populations of B. cubensis from Abaco, Eleuthera and San Salvador, Bahamas with no detectable pattern of geographic distribution or cryptic diversification. Future studies will use population genomic methods to investigate potential drivers of PhyV across western Atlantic populations of B. cubensis. It is important for us to further investigate the low level of genetic diversity and high levels of population connectivity suggested by our results (Fig. 5) with greater resolution through the use of next generation sequencing, such as restriction site associated DNA sequencing (Miller et al., 2007; Davey et al., 2011; Timm \& BrackenGrissom, 2015). We anticipate that further molecular and morphological studies with the addition of environmental data will identify the underlying cause sources of PhyV, which may be due to a complex combination of genetic and environmental factors.

\section{ACKNOWLEDGMENTS}

We would like to thank Dr. Craig Layman and Dr. Jocelyn Curtis-Quick and the Cape Eleuthera Institute for their assistance in the collection of specimens of Barbouria cubensis from Abaco and Eleuthera, Bahamas. We also extend our gratitude to Drs. Raymond Bauer and Sammy de Grave for their expert advice and feedback. We are 
grateful for the support and assistance of the Gerace Research Centre and Bahamian citizens during field work on San Salvador, Bahamas. This study was supported in part by a student research award from the Gerace Research Centre, and The Crustacean Society - Graduate Student Fellowship awarded to RED. Additional support was provided by Florida International University. This is contribution \#140 from the Center for Coastal Oceans Research in the Institute of Water and Environment at Florida International University.

\section{REFERENCES}

Agnalt, A.L., Grefsrud, E.S., Farestveit, E., Larsen, M. \& Keulder, F. (2013) Deformities in larvae and juvenile European lobster (Homarus gammarus) exposed to lower $\mathrm{pH}$ at two different temperatures. Biogeosciences, 10, 7883-7895. https://doi.org/10.5194/bg-10-7883-2013

Ahyong, S. \& O’ Meally, D. (2004) Phylogent of the Decapoda Reptantia: Resolution using three molecular loci and morphology. the Raffles Bulletin of Zoology, 52, 673-693.

Allegue, H., Araya-Ajoy, Y.G., Dingemanse, N.J., Dochtermann, N.A., Garamszegi, L.Z., Nakagawa, S., Réale, D., Schielzeth, H. \& Westneat, D.F. (2017) Statistical Quantification of Individual Differences (SQuID): an educational and statistical tool for understanding multilevel phenotypic data in linear mixed models. Methods in Ecology and Evolution, 8, 257-267. https://doi.org/10.1111/2041$\underline{\text { 210X.12659 }}$

Agrawal, A.A. (2001) Phenotypic plasticity in the interactions and evolution of species. Science, 294 (5541), 321-326. https://doi.org/10.1126/science.1060701

Aguirre, H. \& Hendrickx, M.E. (2005) Abnormal rostrum and telson in two species of Penaeid shrimp (Decapoda, Dendrobranchiata, Penaeidae) from the Pacific coast of Mexico. Crustaceana, 78 (1), 113-119. https://doi.org/10.1163/1568540054024501 
Aznar-Cormano, L., Brisset, J., Chan, T.Y., Corbari, L., Puillandre, N., Utge, J., Zbinden, M., Zuccon, D. \& Samadi, S. (2015) An improved taxonomic sampling is a necessary but not sufficient condition for resolving inter-families relationships in Caridean decapods. Genetica, 143, 195-205. https://doi.org/10.1007/s10709-014$\underline{9807-0}$

Baeza, J.A. (2013) Molecular phylogeny of broken-back shrimps (genus Lysmata and allies): A test of the 'Tomlinson-Ghiselin' hypothesis explaining the evolution of hermaphroditism. Molecular Phylogenetics and Evolution, 69, 46-62. https://doi.org/10.1016/j.ympev.2013.05.013

Baltanás, A., Alcorlo, P. \& Danielopol, D.L. (2002) Morphological disparity in populations with and without sexual reproduction: a case study in Eucypris virens (Crustacea: Ostracoda). Biological Journal of the Linnean Society, 75, 9-19. https://doi.org/10.1046/j.1095-8312.2002.00001.x

Bauer, R.T. (2005) 7 Library of Congress Cataloging-In-Publication Data Remarkable Shrimps: Adaptations and Natural History of the Carideans. Animal nat. V.H. Hutchison (Ed.), University of Oklahoma Press: Norman, Norman, Ok.

Becking, L.E., Renema, W., Santodomingo, N.K., Hoeksema, B.W., Tuti, Y. \& de Voogd, N.J. (2011) Recently discovered landlocked basins in Indonesia reveal high habitat diversity in anchialine systems. Hydrobiologia, 677 (1), 89-105. https://doi.org/10.1007/s10750-011-0742-0

Béguer, M., Feuillassier, L., Elie, P., Boët P. \& Giradin, M. (2010) Exoskeletal deformities in Palaemonidae: are they a threat to survival?. Marine Environmental Research, 69 (3), 109-117. https://doi.org/10.1016/j.marenvres.2009.09.001

Béguer, M., Pasquaud S., Noël, P. Girardin, M. \& Boët, P. (2008) First description of heavy skeletal deformations in Palaemon shrimp populations of European estuaries: the case of the Gironde (France). Hydrobiologia, 607, 225-229. https://doi.org/10.1007/s10750-008-9386-0

Bishop, R.E., Humphreys, W.F., Cukrov, N., Žic, V., BOXSHALL, G.A., Cukrov, M., Iliffe, T.M., Kršinić, F., Moore, W.S., Pohlman, J.W., Sket, B., Bishop, R.E., Kršinić, F., Sket, B., Iliffe, T.M., Žic, V., Moore, W.S., Cukrov, N., Cukrov, M., BOXSHALL, G.A. \& Pohlman, J.W. (2015) 'Anchialine' redefined as a subterranean estuary in a crevicular or cavernous geological setting. Journal of Crustacean Biology, 35 (4), 511-514. https://doi.org/10.1163/1937240X$\underline{00002335}$

Bishop, R.E. \& Iliffe, T.M. (2012) Ecological physiology of the anchialine shrimp Barbouria cubensis: a comparison of epigean and hypogean populations. Marine Biodiversity, 42, 303-310. https://doi.org/10.1007/s12526-012-0113-8 
Bohonak, A.J. (1999) Dispersal, Gene Flow, and Population Structure. The Quarterly Review of Biology, 74 (1), 21-45. https://doi.org/10.1086/392950

Borradaile, L.A. (1900) On some Crustaceans from the South Pacific. Part IV. The crabs. Proceedings fo the General Meetings for the Scientific Business of the Zoological Society of London, 1900 (3), 568-596.

Bracken-Grissom, H.D., Ahyong, S.T., Wilkinson, R.D., Feldmann, R.M., Schweitzer, C.E., Breinholt, J.W., Bendall, M., Palero, F., Chan, T.-Y., Felder, D.L., Robles, R., Chu, K.-H., Tsang, L.-M., Kim, D., Martin, J.W. \& Crandall, K.A. (2014) The emergence of the lobsters: phylogenetic relationships, morphological evolution and divergence time comparisons of an ancient group (Decapoda: Achelata, Glypheidea, Polychelida). Systematic Biology, 63, 457-479. https://doi.org/10.1093/sysbio/syu008

Bracken, H.D., Toon, A, Felder, D.L., Martin, J.W., Finley, M., Rasmussen, J., Palero, F. \& Crandall, K. (2009) The decapod tree of life: compiling the data and moving toward a consensus of decapod evolution. Arthropod Systematics and Phylogeny, 67, 99-116.

Brandt, A. (1988) Morphology and Ultrastructure of the Sensory Spine, a Presumed Mechanoreceptor of Sphaerome hookeri (Crustacea, Isopods), and Remarks on Similar Spines in Other Peracarids. Journal of Morphology, 198, 219-229. https://doi.org/10.1002/jmor.1051980208

Brian, J. V., Fernandes, T., Ladle, R.J. \& Todd, P.A. (2006) Patterns of morphological and genetic variability in UK populations of the shore crab, Carcinus maenas Linnaeus, 1758 (Crustacea: Decapoda: Brachyura). Journal of Experimental Marine Biology and Ecology, 329 (1), 47-54. https://doi.org/10.1016/j.jembe.2005.08.002

Chace, F.A. (1997) The Caridean Shrimps (Crustacea: Decapoda) of the Albatross Philippine Expedition, 1907-1910, part 7: families Atyidae, Eugonatonotidae, Rhynchocinetidae, Bathypalaemonellidae, Processidae, and Hippolytidae. Smithsonian Contributions to Zoology, 587, 1-106. https://doi.org/10.5479/si.19436696.391.1

Chace, F.A. (1972) The shrimps of the Smithsonian-Bredin Caribbean Expeditions with a summary of the West Indian shallowwater species (Crustacea: Decapoda: Natantia). Smithsonian Contributions to Zoology, 98, 1-179. https://doi.org/10.5479/si.00810282.98 
Chace, F.A. \& Manning, R.B. (1972) Two new caridean shrimps, one representing a new family, from marine pools on Ascension Island (Crustacea: Decapoda: Natantia). Smithsonian Contributions to Zoology, 1-18. https://doi.org/10.5479/si.00810282.131

Chown, S.L., Slabber, S., McGeouch, M., Janion, C. \& Leinaas, H.P. (2007) Phenotypic plasticity mediates climate change responses among invasive and indigenous arthropods. Proceedings of Biological sciences, 274 (1625), 2531-2537. https://doi.org/10.1098/rspb.2007.0772

Christoffersen, M.L. (1987) Phylogenetic Relationships of Hippolytid Genera, with an Assignment of New Families for the Crangonoidea and Alpheoidea (Crustacea, Decapoda, Caridea). Cladistics, 3 (4), 348-362. https://doi.org/10.1111/j.1096$\underline{0031.1987 . t b 00898 . x}$

Clark, J. (1989) Koror misticius, new genus, new species (Decapoda: Hippolytidae), a cave shrimp from Palau. Journal of Crustacean Biology, 9 (3), 445-452. https://doi.org/10.2307/1548569

Cockayne, L. \& Allan, H.H. (1926) The Naming of Wild Hybrid Swarms. Nature, 118 (2974), 623-624. https://doi.org/10.1038/118623a0

Cornils, A. \& Held, C. (2014) Evidence of cryptic and pseudocryptic speciation in the Paracalanus parvus species complex (Crustacea, Copepoda, Calanoida). Frontiers in Zoology, 11 (19), 1-17. https://doi.org/10.1186/1742-9994-11-19

Crandall, K.A., Fitzpatrick, J.F., Biology, S. \& Mar, N. (1996) Crayfish Molecular Systematics: Using a Combination of Procedures to Estimate Phylogeny. Systematic Biology, 45, 1-26. https://doi.org/10.1093/sysbio/45.1.1

Cristescu, M.E., Adamowicz, S.J., Vaillant, J.J. \& Haffner, D.G. (2010) Ancient lakes revisited: From the ecology to the genetics of speciation. Molecular Ecology, 19 (22), 4837-4851. https://doi.org/10.1111/j.1365-294X.2010.04832.x

Dawson, M.N. (2005) Incipient speciation of Catostylus mosaicus (Scyphozoa, Rhizostomeae, Catostylidae), comparative phylogeography and biogeography in south-east Australia. Journal of Biogeography, 32 (3), 515-533. https://doi.org/10.1111/j.1365-2699.2004.01193.x

DeWitt, T.J., Robinson, B.W. \& Wilson, D.S. (2000) Functional diversity among predators of a freshwater snail imposes an adaptive trade-off for shell morphology. Evolutionary Ecology Research, 2, 129-148. 
De Grave, S., Li, C.P., Tsang, L.M., Chu, K.H. \& Chan, T.Y. (2014) Unweaving hippolytoid systematics (Crustacea, Decapoda, Hippolytidae): Resurrection of several families. Zoologica Scripta, 43, 496-507. https://doi.org/10.1111/zsc.12067

De Grave, S., Pentcheff, N.D., Ahyong, S.T., Chan, T., Crandall, K.A., Dworschak, P.C., Felder, D.L., Feldmann, R.M., Fransen, C.H.J.M., Goulding, L.Y.D., Lemaitre, R., Low, M.E.Y., Martin, J.W., Ng, P.K.L., Schweitzer, C.E., Tan, S.H., Tshudy, D. \& Wetzer, R. (2009) A classification of living and fossil genra of decapod crustaceans. Raffles Bulltein of Zoology, 21, 1-109.

Duarte, M.S., Maia-Lima, F.A. \& Molina, W.F. (2008) Interpopulational morphological analyses and fluctuating asymmetry in the brackish crab Cardisoma guanhumi Latreille (Decapoda, Gecarcinidae), on the Brazilian Northeast coastline. PanAmerican Journal of Aquatic Sciences, 3 (3), 294-303.

Edwards, D.C. (1996) The inland saline waters of the Bahamas as distinctive scientific resources. In: Proceedings of the Sixth Symposium on Natural History of the Bahamas, pp. 152-162.

Felsenstein, J. \& Churchill, G.A. (1996) A hidden Markov model approach to variation among sites in rate of evolution. Molecular Biology and Evolution, 13, 93-104. https://doi.org/10.1093/oxfordjournals.molbev.a025575

Fernandes, C.M., Gregati R.A. \& Bichuette M.E. (2011) The frist record of external abnormalities in the subterranean Aegla marginata Bond-Buckup \& Buckup, 1994 (Crustacea: Decapoda: Aeglidae), from a karst area of Southeastern Brazil. Subterranean Biology, 8, 33-38. https://doi.org/10.3897/subtbiol.8.1228

Fiedler, G.C., Rhyne, A.L., Segawa, R., Aotsuka, T. \& Schizas, N.V. (2010) The evolution of euhermaphroditism in caridean shrimps: a molecular perspective of sexual systems and systematics. BMC Evolutionary Biology, 10 (297), 14 pp. https://doi.org/10.1186/1471-2148-10-297

Follesa, M.C., Cannas, R., Gastoni, A., Cabiddu, S. Deiana, A.M. \& Cau A. (2008) Abnormal rostrum in Polycheles typhlops Heller, 1862 (Decapoda: Polychelidae) from the Central Western Mediterranean. Journal of Crustacean Biology, 28 (4), 731-734. https://doi.org/10.1651/08-2987.1

Folmer, O., Black, M., Hpeh, W., Lutz, R. \& Vrijenhoek, R. (1994) DNA primers for amplification of mitochondrial cytochrome c oxidase subunit I from diverse metazoan invertebrates. Molecular Marine Biology and Biotechnology, 3, 294 299. 
Fumagalli, L., Snoj, A., Jesenšek, D., Balloux, F., Jug, T., Duron, O., Brossier, F., Crivelli, A.J. \& Berrebi, P. (2002) Extreme genetic differentiation among the remnant populations of marble trout (Salmo marmoratus) in Slovenia. Molecular Ecology, 11, 2711-2716. https://doi.org/10.1046/j.1365-294X.2002.01648.x

Giménez, L. (2006) Phenotypic links in complex life cycles: Conclusions from studies with decapod crustaceans. In: Integrative and Comparative Biology, 46 (5), 615622. https://doi.org/10.1093/icb/icl010

Gonzalez, B.C., Martínez, A., Borda, E., Iliffe, T.M., Fontaneto, D. \& Worsaae, K. (2017) Genetic Spatial Structure of an anchialine cave annelid indicates connectivity within but not between islands of the Great Bahamas Bank. Molecular Phylogenetics and Evolution, 109, 259-270. https://doi.org/10.1016/j.ympev.2017.01.003

Goodman, B.A. \& Johnson, P.T.J. (2011) Disease and the extended phenotype: Parasites control host performance and survival through induced changes in body plan. PLoS ONE, 6 (5), e20193. https://doi.org/10.1371/journal.pone.0020193

Google Earth Pro V 7.3.0.3832. (2014) The Bahamas. 24 $38^{\prime} 03.18^{\prime \prime} \mathrm{N}, 7^{\circ} 16^{\prime}$ 52.61”W. DigitalGlobe 2017.

Hart, C. \& Manning, R.B. (1981) The Cavernicolous Caridean Shrimps of Bermuda (Alpheidae, Hippolytidae, and Atyidae). Journal of Crustacean Biology, 1 (3), 441-456. https://doi.org/10.2307/1547975

Hart Jr., C.W., Manning, R.B. \& Iliffe, T.M. (1985) The fauna of Atlantic marine caves: evidence of dispersal by sea floor spreading while maintaining ties to deep waters. Proceedings of the Biological Society of Washington, 98 (1), 288-292.

Hedrick, P.W. \& Garcia-Dorado, A. (2016) Understanding Inbreeding Depression, Purging and Genetic Rescue. trends in Ecology and Evolution, 31 (12), 940-952. https://doi.org/10.1016/j.tree.2016.09.005

Hobbs, H.H., Hobbs, H.H. \& Daniel, M.A. (1977) A Review of the Troglobitic Decapod Crustaceans of the Americas. Smithsonian Contributions to Zoology, 244, 1-183. https://doi.org/10.5479/si.00810282.244

Holthuis, L. (1973) Caridean Shrimps Found in Land-locked Saltwater Pools at Four Indo-West Pacific Localities (Sinai Peninsula, Funafuti Atoll, Maui and Hawaii Islands): with the Description of One New Genus and Four New Species. Zoologische Verhandelingen, 128, 3-48.

Holthuis, L.B. (1963) On Red Coloured Shrimps (Decapoda, Caridea) from Tropical LandLocked Saltwater Pools. Zoologische mededelingen, 38 (16), 261-179. 
Huelsenbeck, J.P. \& Ronquist, F. (2001) MrBayes: Bayesian inference of phylogenetic trees. Bioinformatics, 17, 745-755.

https://doi.org/10.1093/bioinformatics/17.8.754

Hunter, R.L., Webb, M.S., Iliffe, T.M. \& Bremer, J.R.A. (2008) Phylogeny and historical biogeography of the cave-adapted shrimp genus typhlatya (Atyidae) in the Caribbean Sea and western Atlantic. Jornal of Biogeography, 35, 65-75.

Iliffe, T.M. (2000) Anchialine Cave Ecology. In: Wilkens, H., Culver, D.C. \& Humphreys, W.F. (Ed.), Ecosystems of the World. 30. Subterranean Ecosystems. Elsevier Science, Amsterdam, pp. 59-76.

Iliffe, T.M. (2005) Anchialine Caves Biodiversity. In: Culver, D.C. \& White, W.B. (Ed.), Encyclopedia of Caves. Elsevier, Burlington, MA, pp. 24-30.

Iliffe, T.M. \& Kornicker, L.S. (2009) Worldwide diving discoveries of living fossil animals from the depths of anchialine and marine caves. Smithsonian Contributions to Marine Sciences, 38, 269-280.

Ituarte, R.B., Spivak, E.D. \& Anger, K. (2007) Intraspecific variability in life-history traits of a "freshwater shrimp", Palaemonetes argentinus. Annales de Limnologie International Journal of Limnology, 43 (3), 293-302.

https://doi.org/10.1051/limn:2007007

Kano, Y. \& Kase, T. (2004) Genetic exchange between anchialine cave populations by means of larval dispersal: The case of a new gastropod species Neritilia cavernicola. Zoologica Scripta, 33 (5), 423-437. https://doi.org/10.1111/j.0300$\underline{3256.2004 .00159 . x}$

Kappes, H. \& Sinsch, U. (2002) Temperatureand predator-induced phenotypic plasticity in Bosmina cornuta and B. pellucida (Crustacea: Cladocera). Freshwater Biology, 47 (10), 1944-1955. https://doi.org/10.1046/j.1365-2427.2002.00943.x

Katoh, K. \& Standley, D.M. (2013) MAFFT Multiple Sequence Alignment Software Version 7: Improvements in Performance and Usability. Molecular Biology and Evolution, 30 (4), 772-780. https://doi.org/10.1093/molbev/mst010

Klingenberg, C.P. (2015) Analyzing Fluctuating Asymmetry with Geometric Morphometrics: Concepts, Methods, and Applications. Symmetry, 7, 843-934. https://doi.org/10.3390/sym7020843

Lacy, R.C. \& Alaks, G. (2012) Effects of inbreeding on skeletal size and fluctuating asymmetry of Peromyscus polionotus mice. Zoo Biology, 32 (2), 125-133. https://doi.org/10.1002/zoo.21035 
Lampert, K.P., Bernal, X.E., Rand, S., Mueller, U.G. \& Ryan, M.J. (2007) Island Populations of Physalaemus Pustulosus: History Influences Genetic Diversity and Morphology. Herpetologica, 63 (3), 311-319. https://doi.org/10.1655/00180831(2007)63[311:IPOPPH]2.0.CO;2

Lanfear, R., Frandsen, P.B., Wright, A.M., Sendfeld, t. \& Calcott, B. (2016) PartitionFinder 2: New Methods for Selecting Paritioned Models of Evolution for Molecular and Morphological Phylogenetic Analyses. Molelcular Biology and Evololution, 34 (3), 772-773. https://doi.org/10.1093/molbev/msw260

Lardies, M.A. \& Bozinovic, F. (2008) Genetic Variation for Plasticity in Physiological and Life-History Traits among Populations of an Invasice Species, the terrestrial isopod Porcellio laevis. Evolutionary Ecology Research, 10 (5), 747 -762.

Laverack, M.S. \& Macmillan, D.L. (1999) The sensory dorsal organ of crustaceans: theme and variations. Marine and Freshwater Behaviour and Physiology, 32, 7586. https://doi.org/10.1080/10236249909379040

Laverack, M.S., Macmillan, D.L., Ritchie, G. \& Sandow, S.L. (1996) The Ultrastructure of the Sensory Dorsal Organ of Crustacea. Crustaceana, 69 (5), 636-651. https://doi.org/10.1163/156854096X00646

Lerosey-Aubril, R. \& Meyer, R. (2013) The sensory dorsal organs of crustaceans. Biological Reviews, 88 (2), 406-426. https://doi.org/10.1111/brv.12011

Luppi, T.A. \& Spivak, E.D. (2007) Morphology of megalopa and first crab of Cyrtographsus angulatus, with comments on the presence of anomalous first crab stage in brachyuran crabs. Journal of Crustacean Biology, 27 (1), 80-89. https://doi.org/10.1651/S-2672.1

Maia S.C.A., Molina W.F. \& Maia-Lima F.A. (2009) Analysis of fluctuating asymmetries in marine shrimp Litopenaeus schmitti (Decapoda, Penaaeidae). Pan-American Journal of Aquatic Sciences 4, 55-62.

Malay, (Machel) D., M.C. \& Paulay, G. (2010) Peripatric speciation drives diversification and distributional pattern of reef hermit crabs (Decapoda: Diogenidae: Calcinus). Evolution, 64 (3), 634-662. https://doi.org/10.1111/j.1558-5646.2009.00848.x

Manning, R.B. \& Hart, C.W. (1984) The status of the hippolytid shrimp genera Barbouria and Ligur (Crustacea: Decapoda): A Reevaluation. Proceedings of the Biological Society of Washington, 97, 655-665.

Martens, E., von (1872) Über cubanische Crustaceen nach den Sammlungen Dr. J. Gundlach's. Archiv für Naturgeschichte, 38 (1), 77-147, Plates 4-5. 
McInerney, C.E., Maurice, L., Robertson, A.L., Knight, L.R.F.D., Arnscheidt, J., Venditti, C., Dooley, J.S.G., Mathers, T., Matthijs, S., Eriksson, K., Proudlove, G.S. \& Hänfling, B. (2014) The ancient Britons: Groundwater fauna survived extreme climate change over tens of millions of years across NW Europe. Molecular Ecology, 23 (5), 1153-1166. https://doi.org/10.1111/mec.12664

Mejía, L.M., Zarza, E. \& López, M. (2008) Barbouria yanezi sp. nov., a new species of cave shrimp (Decapoda, Barbouriidae) from Cozumel Island, Mexico. Crustaceana, 81 (6), 663-672. https://doi.org/10.1163/156854008784513474

Moncada, F.G., \& Gomes, O. (1980) Alguenos aspectos biológicos de três especies del gênero Callinectes (Crustacea, Decapoda). Revista Cubana de Investigación Pequera, 5, 1-35.

Munasinghe, D.H.N. \& Senevirathna J.D.M. (2015) Phenotypic plasticity and genetic variation of two wild populations of green tiger shrimp (Penaeus semisulcatus-De Haan, 1844). International Journal of Marine Science, 5 (5), 1-8. https://doi.org/10.5376/ijms.2015.05.0005

Nishizaki, M.T., Barron, S. \& Carew, E. (2015) Thermal stress increases fluctuating asymmetry in marine mussels: environmental variation and developmental instability. Ecosphere, 6 (5), 85. https://doi.org/10.1890/ES14-00399.1

O’Grady, J.J., Brook, B.W., Reed, D.H., Ballou, J.D., Tonkyn, D.W. \& Frankham, R. (2006) Realistic levels of inbreeding depression strongly affect extinction risk in wild populations. Biological Conservation, 133 (1), 42-51. https://doi.org/10.1016/j.biocon.2006.05.016

Oha, T. \& Paal, J. (2004) Multivariate analysis of morphological variation among closely related species Bromus Japonicus, B. squarrosus and B. arvensis (Paceae) in comparison with isozyme evidence. Nordic Journal of Botany, 24 (6), 691-702. https://doi.org/10.1111/j.1756-1051.2004.tb01939.x

Onaga, H., Fiedler, G. \& Baeza, J. (2012) Protandric simultaneous hermaphroditism in Parhippolyte misticia (Clark, 1989)(Caridea: Hippolytidae): implications for the evolution of mixed sexual systems in. Journal of Crustacean Biology, 32 (3), 383-394. https://doi.org/10.1163/193724012X626520

Palumbi, S., Martin, A., Romano, S., McMillan, W.O., Stice, L. \& Grabowski, G. (1991) the Simple Fool's Guide to PCR. Department of Zoology and Kewalo Marine Laboratory, University of Hawaii, Honolulu, 44 pp. 
Pérez-Moreno, J.L., Iliffe, T.M. \& Bracken-Grissom, H.D. (2016) Life in the Underworld: Anchialine cave biology in the era of speleogenomics. International Journal of Speleology, 45 (2), 149-170. https://doi.org/10.5038/1827$\underline{\text { 806X.45.2.1954 }}$

Perry, W.L., Feder, J.L \& Lodge, D.M. (2001) Implications of Hydridization between Introducted and Resident Orconectes Crayfishes. Conservation Biology, 15 (6), 1656-1666. https://doi.org/10.1046/j.1523-1739.2001.00019.x

Porter, M.L., Perez-Losada, M. \& Crandall, K.A. (2005) Model-based multi-locus estimation of decapod phylogeny and divergence times. Molecular Phylogenetics and Evolution, 37, 355-369. https://doi.org/10.1016/j.ympev.2005.06.021

Page, T.J., Short, J.W., Humphrey, C.L., Hillyer, M.J. \& Hughes, J.M. (2008) Molecular systematics of the Kakaducarididae (Crustacea: Decapoda: Caridea). Molecular Phylogenetics and Evolution, 46, 1003-1014. https://doi.org/10.1016/j.ympev.2007.12.020

R Core Team (2016) R: A language and environment for statistical computing. $R$ Foundation for Statistical Computing, Vienna, Austria, Available from: https://www.R-project.org/

Rafineque, C.S. (1815) Analyse de la Nature, ou Tableau de l'Univers et de Corps Organisés. Palermo, L'Imprimerie de Jean Barravecchia. 224 pp. https://doi.org/10.5962/bhl.title.106607

Rathbun, M.J. (1912) Some Cuban Crustacea, with notes on the Astacidae by Walter Faxon, and a list of Isopoda, by Harriet Richardson. Bulletin of the Museum of Comparative Zoology, 54 (15), 451-460, Pls. 1-5.

Reuschel, S. \& Schubart, C.D. (2007) Contrasting genetic diversity with phenotypic diversity in coloration and size in Xantho poressa (Brachyura: Xanthidae), with new results on its ecology. Marine Ecology, 28 (2), 296-305. https://doi.org/10.1111/j.1439-0485.2006.00139.x

Ribardière, A., Daguin-Thiébaut, C., Houbin, C., Coudret, J., Broudin, C., Timsit, O. \& Broquet, T. (2017) Geographically distinct patterns of reproductive isolation and hybridization in two sympatric species of the Jaera albifrons complex (marine isopods). Ecology and Evolution, 7 (14), 5352-5365. https://doi.org/10.1002/ece3.3106

Ripley, B., Venables, B., Bates, D.M., Hornik, K., Gebhardt, A. \& Firth, D. (2018) Support Functions and Datasets for Venables and Ripley's MASS. Available from: http://www.stats.ox.ac.uk/pub/MASS4/ 
Roberts, D.W. (2016) Ordination and Multivariate Analysis for Ecology. Available from: http://ecology.msu.montana.edu/labdsv/R

Robles, R., Schubart, C.D., Conde, J.E., Carmona-Suarez, C., Alvarez, F., Villalobos, J.L. $\&$ Felder, D.L. (2007) Molecular phylogeny of the American Callinectes Stimpson, 1860 (Brachyura: Portunidae), based on two partial mitochondrial genes. Marine Biology, 150, 1265-1274. https://doi.org/10.1007/s00227-006$\underline{0437-7}$

Russ, A., Santos, S.R. \& Muir, C. (2010) Genetic population structure of an anchialine shrimp, Metabetaues lohena (Crustacea: Alpheidae), in the Hawaiin Islands. Revista de Biología tropical, 58 (1), 159-170. https://doi.org/10.15517/rbt.v58i1.5201

Santos, S.R. (2006) Patterns of genetic connectivity among anchialine habitats: a case study of the endemic Hawaiin shrimp Halocaridina rubra on the island of Hawaii. Molecular Ecology, 15, 2699-2718. https://doi.org/10.1111/j.1365294X.2006.02965.x

Sket, B. (2005) Anchialine Caves. In: Culver, D.C. \& White, W.B. (Eds.), Encyclopedia of Caves. Elsevier Academic Press, 30-37.

Smith, L.D. \& Palmer, A.R. (1994) Effects of manipulated diet on size and performance of brachyuran crab claws. Science, 264 (5159), 710-712. https://doi.org/10.1126/science.264.5159.710

Song, H., Buhay, J.E., Whiting, M.F. \& Crandall, K.A. (2008) Many species in one: DNA barcoding overestimates the number of species when nuclear mitochondrial pseudogenes are coamplified. PNAS, 105 (36), 13486-13491. https://doi.org/10.1073/pnas.0803076105

Stamatakis, A. (2014) RAxML version 8: a tool for phylogenetic analysis and postanalyses of large phylogenies. Bioinformatics, 30 (9), 1312-1313. https://doi.org/10.1093/bioinformatics/btu033

Stearns, S. (1989) The evolutionary significance of phenotypic plasticity. BioScience, 39 (7), 436-445. https://doi.org/10.2307/1311135

Steinauer, M.L., Nickol, B.B. \& Ortí, G. (2007) Cryptic speciation and patterns of phenotypic variation of a highly variable acanthocephalan parasite. Molecular Ecology, 16 (19), 4097-4109. https://doi.org/10.1111/j.1365-294X.2007.03462.x

Stibor, H. \& Lüning, J. (1994) Predator-inudced phenotypic variation in the pattern of growth and reproduction in Daphnia hyalina (Crustacea: Cladocera). British Ecological Society, 8 (1), 97-101. https://doi.org/10.2307/2390117 
Stock, J.H. (1986) The concept "anchialine” reconsidered. Stygologia, 2, 90-92.

Swofford, D.L. (2002) PAUP*: phylogenetic analysis using parsimony (* and other methods). Sinauer Associates, Sunderland, MA.

Trussell, G.C. (1996) Phenotypic plasticity in an intertidal snail: The role of a common crab predator. Evolution, 50 (1), 448- 454. https://doi.org/10.1111/j.1558$\underline{5646.1996 . t b 04507 . x}$

Trussell, G.C. \& Smith, L.D. (2000) Induced defenses in response to an invading crab predator: An explanation of historical and geographic phenotypic change. PNAS, 97 (5), 2123-2127. https://doi.org/10.1073/pnas.040423397

Tsang, L.M., Ma, K.Y., Ahyong, S.T., Chan, T.-Y. \& Chu, K.H. (2008) Phylogeny of Decapoda using two nuclear protein-coding genes: origin and evolution of the Reptantia. Molelcuar Phylogenetics and Evolution, 48, 359-368. https://doi.org/10.1016/j.ympev.2008.04.009

Vogt, G., Huber, M., Thiemann, M., van den Boogaart, G., Schmitz, O.J. \& Schubart, C.D. (2008) Production of different phenotypes from the same genotype in the same environment by developmental variation. the Journal of Experimental Biology, 211 (4), 510-23. https://doi.org/10.1242/jeb.008755

Weese, D.A., Fujita, Y. \& Santos, S.R. (2013) Multiple colonizations lead to cryptic biodiversity in an island ecosystem: comparative phylogeography of anchialine shrimp species in the Ryukyu Archipelago, Japan. Biological Bulletin, 225, 2441. https://doi.org/10.1086/BBLv225n1p24

Weese, D.A., Fujita, Y., Hidaka, M. \& Santos, S.R. (2012) The Long and Short of it: Genetic Variation and Population Structure of the Anchialine Atyid Shrimp Caridina rubella on Miyako-Jima, Japan. Journal of Crustacean Biology, 32 (1), 109-117. https://doi.org/10.1163/193724011X615389

Wicksten, M.K. (1996) Parhippolye cavernicola, new species (Decapoda: Caridea: Hippolytidae) from the Tropical Eastern Pacific, with taxonomic remarks on the genera Somersiella and Koror. Journal of Crustacean Biology, 16 (1), 201-207. https://doi.org/10.2307/1548941

Wolf, H.G. \& Mort, M.A. (1986) Inter-specific hybridization underlies phenotypic varaibility in Daphnai populations. Oecologia, 68, 507-511. https://doi.org/10.1007/BF00378763 


\section{TABLES}

Table 1. Common morphological characters used to discriminate among Barbouriidae spp. separated by prescribed character states for Barbouria cubensis, B. yanezi, Parhippolyte sterreri and Janicea antiguensis, and the most common, extremes and percentage of individuals exhibiting PhyV. ${ }^{*}$ denotes percentages for which the character was examined for $\geq 121$ individuals. Reproduced with permission from Magnolia Press.

\begin{tabular}{|c|c|c|c|c|c|c|c|}
\hline \multirow[b]{2}{*}{ Carapace } & Barbouria cubensis & \multirow[t]{2}{*}{ Barbouria yanezi } & \multirow[t]{2}{*}{ Parhippolyte sterreri } & \multirow[t]{2}{*}{ Janicea antiguensis } & \multicolumn{3}{|c|}{ Barbouria cubensis sp. Examined } \\
\hline & & & & & Most Common & Extremes & \% PhyV \\
\hline antennal tooth & present & present & present & present & present & absent / bifurcate & $16.4 \%$ \\
\hline branchiostegal tooth & present & present & present & present & present & absent / 4 spines & $7.3 \%$ \\
\hline Rostrum & simple & simple & simple & simple & simple & absent / trifid & $7.1 \%$ \\
\hline length vs antennular peduncle & past 1 st article & end of 2 nd article & $\begin{array}{l}\text { scarcely past } 1 \mathrm{st} \\
\text { article }\end{array}$ & end of 1 st article & medial 2nd article & $\begin{array}{l}\text { absent / end of 3rd } \\
\text { article }\end{array}$ & $25.9 \%$ \\
\hline total dorsal teeth & $4-7$ & $3-7$ & $3-4$ & $3-4$ & $5 \pm 1.29$ & $0 / 15$ & $13.5 \%$ \\
\hline postorbital dorsal teeth & $3-4$ & $2-4$ & $1-2$ & $1-2$ & $3 \pm 0.86$ & $0 / 10$ & $30.2 \%$ \\
\hline ventral teeth & $1-7$ & $3-9$ & $4-5$ & 1 & $3 \pm 1.61$ & $0 / 8$ & $9.1 \%$ \\
\hline \multicolumn{8}{|l|}{ Eye } \\
\hline eyestalk spine/tubercle & absent & absent & absent & absent & absent & absent / present & $18.5 \%$ \\
\hline cornea pigmentation & darkly pigmented & darkly pigmented & darkly pigmented & darkly pigmented & darkly pigmented & unpigmented & $6.9 \%$ \\
\hline cornea width vs eyestalk & narrower & narrower & broader & broader & narrower & absent/broader & $16.6 \%$ \\
\hline \multicolumn{8}{|l|}{ Scaphocerite } \\
\hline length vs width & $2.9 \mathrm{X}$ & $2.47 \mathrm{X}$ & $3 X$ & $4 \mathrm{X}$ & $3.04 \mathrm{X} \pm 0.28$ & $2.6 \mathrm{X} / 4.73 \mathrm{X}$ & $87.0 \% *$ \\
\hline \multicolumn{8}{|l|}{ Abdominal Pleura } \\
\hline 1st to 4 th & rounded & rounded & rounded & rounded & rounded & acute / square & $12.7 \%$ \\
\hline 5 th \& 6th & $\begin{array}{l}\text { posteroventrally } \\
\text { armed }\end{array}$ & $\begin{array}{l}\text { posteroventrally } \\
\text { armed }\end{array}$ & $\begin{array}{l}\text { posteroventrally } \\
\text { armed }\end{array}$ & $\begin{array}{l}\text { posteroventrally } \\
\text { armed }\end{array}$ & $\begin{array}{l}\text { posteroventrally } \\
\text { armed }\end{array}$ & $\begin{array}{l}\text { rounded \& } \\
\text { unarmed }\end{array}$ & $13.0 \%$ \\
\hline \multicolumn{8}{|l|}{ Telson } \\
\hline total dorsal spines & 4 & 4 & 4 & 4 & $4 \pm 1.23$ & $0 / 13$ & $20.8 \%$ \\
\hline total posterior spines & 6 & 6 & 6 & 6 & $6 \pm 1.49$ & $0 / 23$ & $41.7 \%$ \\
\hline terminal margin shape & broadly rounded & rounded & pointed & pointed & rounded & flat / pointed & $13.0 \%$ \\
\hline \multicolumn{8}{|l|}{ 2nd Pereiopod } \\
\hline ischium subdivisions & 0 & 4 & $0-4$ & 0 & $3-4 \pm 1.39$ & $0 / 8$ & $95.5 \% *$ \\
\hline merus subdivisions & $11-17$ & 11 & 10 & $11-14$ & $13 \pm 3.21$ & $8 / 20$ & $20.1 \% *$ \\
\hline carpus subdivisions & $21-32$ & $23-34$ & $25-27$ & $26-31$ & $30 \pm 4.44$ & $20 / 40$ & $40.3 \% *$ \\
\hline \multicolumn{8}{|l|}{ Pleopod (male) } \\
\hline $\begin{array}{r}\text { appendix masculina vs interna } \\
(\sim \text { length })\end{array}$ & shorter $(\sim 1 / 2-3 / 4)$ & shorter $(\sim 2 / 3)$ & subequal & longer & shorter $(\sim 2 / 3)$ & $\begin{array}{l}\text { shorter }(\sim 1 / 3) / \\
\text { longer }\end{array}$ & $10.0 \% *$ \\
\hline $\begin{array}{r}\text { appendix masculina terminal } \\
\text { setae }\end{array}$ & $5-7$ & 11 & 14 & 8 & $10 \pm 2.37$ & $5 / 16$ & $93.0 \% *$ \\
\hline
\end{tabular}


Table 2. Species used for phylogeny reconstruction for examining cryptic diversity

within Barbouria cubensis (Dataset 1), showing taxon, collection locality, catalog

number, and GenBank accession numbers for partial sequences of 16S, COI respectively.

Reproduced with permission from Magnolia Press.

\begin{tabular}{|c|c|c|c|c|}
\hline Taxon & Collection Locality & Catalog No. & $16 \mathrm{~S}$ & COI \\
\hline Barbouria cubensis & Abaco, Bahamas & HBG5588 & MK501714 & MK575421 \\
\hline \multirow[t]{57}{*}{ von martens, 1872} & & HBG5589 & MK501715 & MK575422 \\
\hline & & HBG5632 & MK501718 & MK575425 \\
\hline & & HBG5660 & MK501719 & MK575426 \\
\hline & & HBG5680 & MK501720 & MK575427 \\
\hline & & HBG5687 & MK501721 & MK575428 \\
\hline & Eleuthera, Bahamas & HBG3362 & MK501710 & MK575417 \\
\hline & & HBG3363 & MK501711 & MK575418 \\
\hline & & HBG3372 & MK501712 & MK575419 \\
\hline & & HBG3373 & MK501713 & MK575420 \\
\hline & & HBG5612 & MK501716 & MK575423 \\
\hline & & HBG5621 & MK501717 & MK575424 \\
\hline & Mayaguana, Bahamas & HBG3187 & MK501708 & MK575415 \\
\hline & & HBG3188 & MK501709 & MK575416 \\
\hline & San Salvador, Bahamas & OUMNH.ZC.2010-05-003 & KF023098 & - \\
\hline & & HBG1399 & MK501653 & MK575359 \\
\hline & & HBG1764 & MK501654 & MK575360 \\
\hline & & HBG1779 & MK501655 & MK575361 \\
\hline & & HBG1780 & MK501656 & MK575362 \\
\hline & & HBG1802 & MK530650 & MK575363 \\
\hline & & HBG1815 & MK501657 & MK575364 \\
\hline & & HBG1817 & MK501658 & MK575365 \\
\hline & & HBG1819 & MK501659 & MK575366 \\
\hline & & HBG1829 & MK501660 & MK575367 \\
\hline & & HBG1832 & MK501661 & MK575368 \\
\hline & & HBG1841 & MK501662 & MK575369 \\
\hline & & HBG1842 & MK501663 & MK575370 \\
\hline & & HBG1848 & MK501664 & MK575371 \\
\hline & & HBG1857 & MK501665 & MK575372 \\
\hline & & HBG1907 & MK501666 & MK575373 \\
\hline & & HBG1924 & MK501667 & MK575374 \\
\hline & & HBG1934 & MK501668 & MK575375 \\
\hline & & HBG1935 & MK501669 & MK575376 \\
\hline & & HBG1936 & MK501670 & MK575377 \\
\hline & & HBG1937 & MK501671 & MK575378 \\
\hline & & HBG1938 & MK501672 & MK575379 \\
\hline & & HBG1939 & MK501673 & MK575380 \\
\hline & & HBG1952 & MK501674 & MK575381 \\
\hline & & HBG1956 & MK501675 & MK575382 \\
\hline & & HBG1959 & MK501676 & MK575383 \\
\hline & & HBG1993 & MK501677 & MK575384 \\
\hline & & HBG2009 & MK501678 & MK575385 \\
\hline & & HBG2018 & MK501679 & MK575386 \\
\hline & & HBG 2027 & MK501680 & MK575387 \\
\hline & & HBG2028 & MK501681 & MK575388 \\
\hline & & HBG2034 & MK501682 & MK575389 \\
\hline & & HBG2035 & MK501683 & MK575390 \\
\hline & & HBG2036 & MK501684 & MK575391 \\
\hline & & HBG2056 & MK501685 & MK575392 \\
\hline & & HBG2068 & MK501686 & MK575393 \\
\hline & & HBG2113 & MK501687 & MK575394 \\
\hline & & HBG2121 & MK501688 & MK575395 \\
\hline & & HBG 2123 & MK501689 & MK575396 \\
\hline & & HBG2151 & MK501690 & MK575397 \\
\hline & & HBG 2167 & MK501691 & MK575398 \\
\hline & & HBG2198 & MK501692 & MK575399 \\
\hline & & HBG2201 & MK501693 & MK575400 \\
\hline & & HBG2264 & MK501694 & MK575401 \\
\hline
\end{tabular}




\section{Table 2. (Continued)}

\begin{tabular}{|c|c|c|c|c|}
\hline Taxon & Collection Locality & Catalog No. & $16 \mathrm{~S}$ & COI \\
\hline Barbouria cubensis & Yucatán Peninsula of & HBG2772 & MK501704 & MK575411 \\
\hline \multirow{3}{*}{ von Martens, 1872} & Mexico & HBG2773 & MK501705 & MK575412 \\
\hline & & HBG 2774 & MK501706 & MK575413 \\
\hline & & HBG2775 & MK501707 & MK575414 \\
\hline \multicolumn{5}{|l|}{ Outgroups } \\
\hline \multicolumn{5}{|l|}{ Janicea antiguensis } \\
\hline Chace, 1972 & Cape Verde, Africa & OUMNH.ZC.2004-15-002 & KF023112 & - \\
\hline \multicolumn{5}{|l|}{ Parhippolyte sterreri } \\
\hline \multirow[t]{3}{*}{ Hart \& Manning, 1981} & Iguana Cay, Bahamas & MNHN-IU-2012-1057 & KP725619 & KP759480 \\
\hline & San Salvador, Bahamas & HBG2189 & MK501722 & MK575429 \\
\hline & & HBG2274 & MK501723 & MK575430 \\
\hline \multicolumn{5}{|l|}{ Parhippolyte uveae } \\
\hline Borradaile, 1900 & & MNHN-IU-2012-1001 & KP725621 & - \\
\hline \multicolumn{5}{|l|}{ Parhippolyte misticia } \\
\hline Clark, 1989 & & & HQ315560 & - \\
\hline Lysmata amboinensis & Hong Kong/ Bise Point, & & & \\
\hline \multirow[t]{2}{*}{ De Man, 1888} & Okinawa, Japan & MSLH:CA23Lyamb & KF023091 & - \\
\hline & & UNML:32.9451 & - & JF346249 \\
\hline
\end{tabular}




\section{SUPPLEMENTAL TABLES}

Table S1. Morphological characters included in data subset 1t and 1b. Reproduced with permission from Magnolia Press.

\begin{tabular}{|c|c|c|}
\hline Character (\# of characters used) & & prescribed state \\
\hline Carapace (2) & & Smooth \\
\hline 1 & suborbital tooth (antennal spine) & Present \\
\hline $\begin{array}{l}2 \\
\text { Sensory Dorsal Organ (2) }\end{array}$ & branchiostegal tooth & Present \\
\hline 1 & in cardiac notch & Undescribed \\
\hline $\begin{array}{l}2 \\
\text { Rostrum (4) }\end{array}$ & posterior to epigastric spine & $\begin{array}{l}\text { Undescribed } \\
\text { margins dentate }\end{array}$ \\
\hline 1 & length vs. antennular peduncle & not past 2 nd article \\
\hline 2 & dorsal rostral teeth (total) & 4 to 7 \\
\hline 3 & postorbital rostral tooth count & 3 to 4 \\
\hline $\begin{array}{l}4 \\
\text { Eye (2) }\end{array}$ & ventral rostral teeth (total) & 1 to 7 \\
\hline 1 & $\begin{array}{c}\text { cornea pigmented } \\
\text { cornea width vs. stalk width }\end{array}$ & $\begin{array}{c}\text { pigmented cornea } \\
\text { narrower than eyestalk }\end{array}$ \\
\hline $\begin{array}{l}2 \\
\text { Abdomen (4) }\end{array}$ & eyestalk bearing spine/tubercle & Absent \\
\hline 1 & $\begin{array}{c}\text { pleura } 1 \& 2 \\
\text { pleura of 2nd somite } \\
\text { pleura of 3rd somite } \\
\text { 3rd posterolateral tooth }\end{array}$ & $\begin{array}{l}\text { rounded laterally } \\
\text { overlapping } 1 \text { st } \& 3^{\text {rd }} \\
\text { rounded/obtuse } \\
\text { Absent }\end{array}$ \\
\hline 2 & $\begin{array}{c}\text { pleura of } 4 \text { th somite } \\
\text { 4th posterolateral tooth }\end{array}$ & $\begin{array}{c}\text { Rounded } \\
\text { Absent }\end{array}$ \\
\hline 3 & $\begin{array}{l}\text { angle of pleura of } 5 \text { th somite } \\
5 \text { th posterolateral tooth } \\
\text { angle of pleura of } 6 \text { th somite }\end{array}$ & $\begin{array}{c}\text { Acute } \\
\text { Present } \\
\text { short and acute }\end{array}$ \\
\hline 4 & $\begin{array}{l}\text { posterior ventral angle tooth } \\
6 \text { th posterolateral tooth }\end{array}$ & $\begin{array}{l}\text { Present } \\
\text { Present }\end{array}$ \\
\hline Telson (4) & & \\
\hline 1 & telson shape & elongate \& slender \\
\hline 2 & dorsal margin spines & 2 pairs of spines \\
\hline 3 & terminal margin shape & blunted apex \\
\hline 4 & $\begin{array}{l}\text { terminal margin spines } \\
\text { length of terminal spines }\end{array}$ & $\begin{array}{c}3 \text { pairs } \\
\text { middle pair longest }\end{array}$ \\
\hline Uropod (3) & & \\
\hline 1 & length vs telson & slightly longer \\
\hline 2 & outer margin shape & exopod straight \\
\hline 3 & $\begin{array}{l}\text { terminal tooth } \\
\text { inner movable spine }\end{array}$ & $\begin{array}{l}\text { Present } \\
\text { Present }\end{array}$ \\
\hline Antennular Peduncle (2) & & \\
\hline 1 & basal segment spine/tubercle & Absent \\
\hline 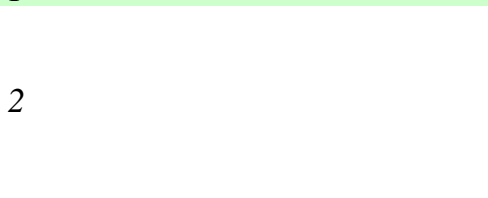 & $\begin{array}{l}\text { basal segment length } \\
\text { stylocerite terminal spine } \\
\text { 2nd segment length vs. 1st } \\
\text { 2nd segment length vs 3rd } \\
\text { simple flagella }\end{array}$ & $\begin{array}{l}\text { Longest } \\
\text { Present } \\
\text { Shorter } \\
\text { Longer } \\
\text { Present }\end{array}$ \\
\hline Pereiopod (2) & & \\
\hline 1 & $2^{\text {nd }}$ articles subdivided & Present \\
\hline 2 & 3rd-5th articles not subdivided & Absent \\
\hline
\end{tabular}


Table S2. Additional morphological characters used in data subset $2 \mathrm{t}$ and $2 \mathrm{~b}$. Reproduced with permission from Magnolia Press.

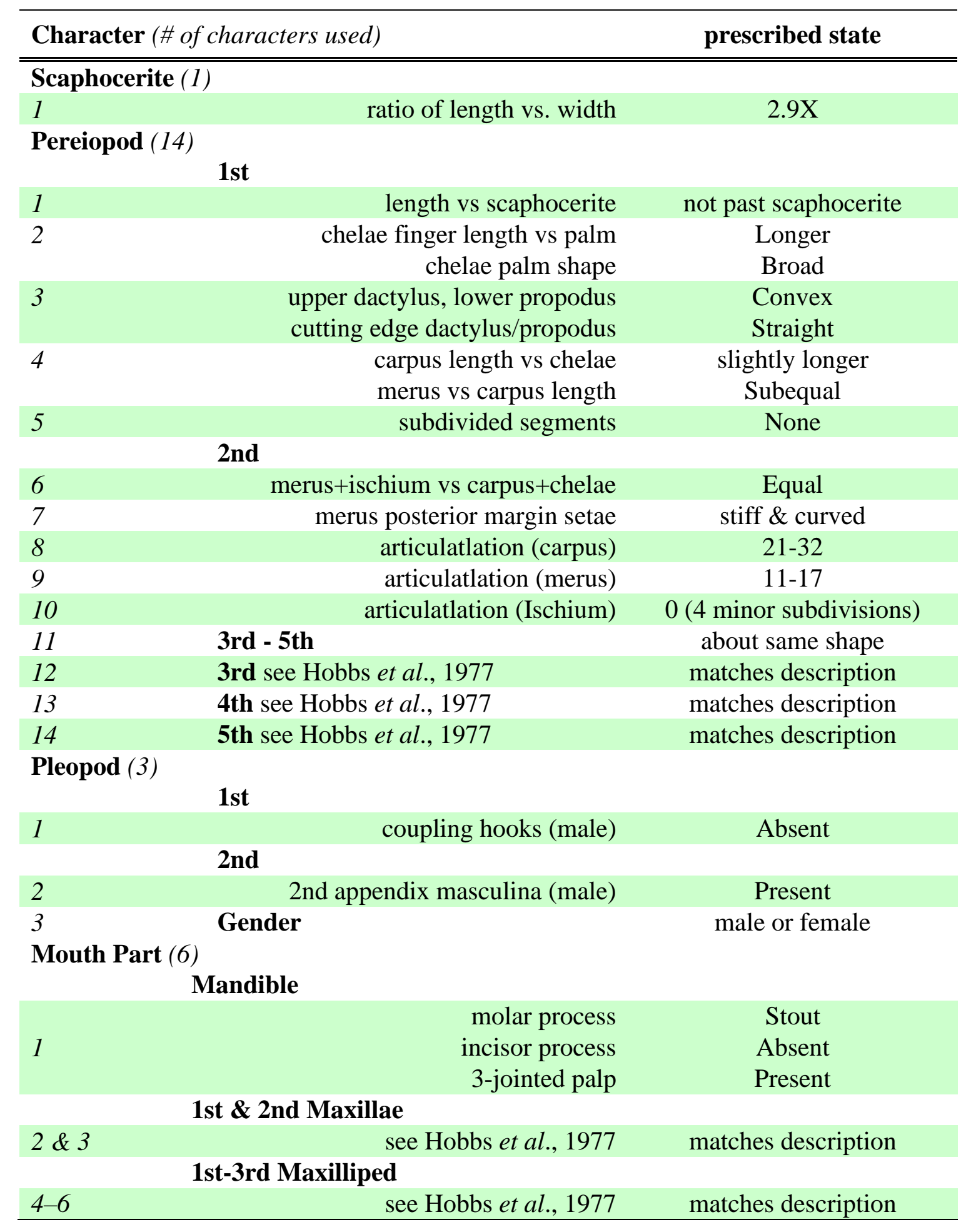


Table S3. morphological characters used to evaluate sexual dimorphism in place of characters used in data for 1st and 2nd pleopods. Reproduced with permission from Magnolia Press.

\begin{tabular}{lrr}
\hline Character $(\#$ of characters used $)$ & prescribed state \\
\hline \hline Pleopod $(2)$ & & \\
& 2nd & $5-9$ or $5-7$ \\
1 & appendix masculina setae & $1 / 2$ to $2 / 3$ \\
\hline
\end{tabular}

FIGURE CAPTIONS

Figure 1. Barbouria cubensis, (top) left lateral view of live specimen (HBG1911), (bottom) schematic drawing by R.E. Ditter of general morphological characters within Caridea. Reproduced with permission from Magnolia Press.

Figure 2. Map of Bahamian Islands with sites sampled from 2012-2016 (a) Abaco site codes and names labeled from North to South: ADS, Dripping Stones; ALP, Lora's Pond; ARS, Runge's Sinkhole (b) Eleuthera site codes and names labeled from North to South: EPC, Preacher's Cave Blue Hole; EDM, Dump Pond; ETD, Too Deep Pond; ESS, Savannah Sound; ESP, Shrimp Pond; EMN, Mackery Nixon Pond (c) San Salvador site codes and names labeled from northern most moving clockwise: LHC, Light House Cave; SSL, South Stout's Lake; MDP, Mermaid Pond; MNP, Merman Pond; PCC, Pigeon Creek Conduit; DCP, Dunk City Pond; WBH, Watling's Blue Hole; BH2, Blue Hole \#2; BH5, Blue Hole \#5; RED, Redrum Pond; WLL, William's Pond; LIL, Little 
Lake; MJC, Major's Cave. $\boldsymbol{i}$; site codes and names labeled from northern most moving clockwise: RHP, Reckley Hill Pond; PNP, Pain Pond; WDP, Wild Dilly Pond; OYP, Oyster Pond; SHP, Shrimp Holes. ii; site codes and names labeled from North to South: PTN, Plantation Pond; SPX, Small Pox Pond; RBH, Rolle's Blue Hole; LRP, Tilde Pond; BRP, Big Rob Pond; BDP, Big Drink Pond. Reproduced with permission from Magnolia Press.

Figure 3. Expected phenotypes for $\underline{B}$. cubensis (left column) compared to examples of observed variable phenotypes; (a-d) teeth on rostrum and rostrum length, and the presence of antennal and branchiostegal spines $(\mathbf{e}-\mathbf{h})$ rostrum length, teeth and shape, antennal and branchiostegal teeth and abnormalities of carapace (i-l) eyes, cornea width versus eyestalk width, and the presence of spines on eyestalk. Images correspond to the following catalog numbers for specimen vouchers housed in the Florida International Crustacean Collection: a*, HBG1843; b, HBG2162; c, HBG2011; d, HBG5644; e*, HBG1843; f, HBG2139; g, HBG2095; h, HBG1935; i*, HBG1843; j, HBG 1952; k, HBG1776; 1, HBG2217. Reproduced with permission from Magnolia Press.

Figure 3 con't. $(\mathbf{m}-\mathbf{p})$ shape and armament of pleura of the abdominal somites $(\mathbf{q}-\mathbf{t})$ telson shape, dorsal spines and terminal spines $(\mathbf{u}-\mathbf{x})$ shape and spines of terminal margin of telson. Yellow lines and arrows indicate expected characters, red lines and arrows indicate variable characters. * denotes examples of expected phenotypes for B. cubensis. Images correspond to the following catalog numbers for specimen vouchers housed in the Florida International Crustacean Collection: m*, HBG1843; n, HBG1932; o, HBG1934; 
p, HBG1398; q*, HBG1843; r, HBG1936; s, HBG1937; t, HBG1970; u*, HBG1843; v, HBG1777; w, HBG1937; x, HBG2098. Reproduced with permission from Magnolia Press.

Figure 4. An unweighted pair-group method with arithmetic averages (UPGMA) dendrogram of morphological data in Subset \#2 labeled with site codes corresponding to figure 2. Bootstrap values $>90 \%$ are noted to the right of nodes. Reproduced with permission from Magnolia Press.

Figure 5. Bayesian (BI) phylogram for Barbouria cubensis $(n=70)$ based on a $16 \mathrm{~S} \&$ COI concatenated data set. BI posterior probabilities and Maximum Likelihood (ML) bootstrap values noted below branches. Values $>0.7$ for ML and $>90 \%$ for BI are shown and represented by percentages. Vertical bars represent collection locality. AIB = Abaco, Bahamas, EIB = Eleuthera, Bahamas, $\mathrm{MIB}=$ Mayaguana, Bahamas, $\mathrm{SSB}=\mathrm{San}$ Salvador, Bahamas, and YMx = Yucatán, Mexico. Catalog numbers represent tissue vouchers from the Florida International Crustacean Collection (FICC). Reproduced with permission from Magnolia Press.

\section{SUPPLEMENTAL FIGURE CATPIONS}

Figure S1. Phenotypic hypervariation exhibited by B. cubensis; (a-c) variations in the shape and surface of the carapace, $(\mathbf{d}-\mathbf{f})$ additional and missing teeth without carina, $(\mathbf{g}-$ h) position of sensory dorsal organ associated with epigastric tooth and within the cardiac region $(\mathbf{j}-\mathbf{l})$ asymmetry in the presence of cornea pigmentation and a terminal spine or 
tubercle on the eyestalk. Images correspond to the following catalog numbers for specimen vouchers housed in the Florida International Crustacean Collection: a, HBG1793; b, HBG1918; c, HBG2215; d \& e, HBG1808; f, HBG1909; g-i, 1801 HBG; $\mathrm{j}-1$, HBG1849. Reproduced with permission from Magnolia Press.

Figure S2. Phenotypic hypervariation exhibited by B. cubensis; (a) asymmetrical lateral compression of scaphocerite, and the absence of the rostrum and antennal tooth while the carina are present $(\mathbf{b} \& \mathbf{c})$ dorsal and ventral view of the ischium of the $2^{\text {nd }}$ pereiopod with six subdivisions (d) lateral extrusions along carapace, (e) bifid rostrum, antennal and branchiostegal spines absent and carapace not smooth (f) rhizocephalan parasite, (g-l) additional examples of PhyV in character located on the cephalothorax. Images correspond to the following catalog numbers for specimen vouchers housed in the Florida International Crustacean Collection: a, HBG1907; b \& c, HBG1904; d, HBG2227; e, HBG2011; f, HBG2083; g, HBG1816; h, HBG1872; i, HBG1882; j, HBG2095; k, HBG1982; 1, HBG1793. Reproduced with permission from Magnolia Press.

Figure S3. Phenotypic hypervariation exhibited by B. cubensis; (a \& b) abnormal shape and armament of the pleura of the abdominal somites, $(\mathbf{d}-\mathbf{l})$ additional examples of PhyV in characters located on the telson and uropods. Images correspond to the following catalog numbers for specimen vouchers housed in the Florida International Crustacean Collection: a, HBG2093; b, HBG1398; c, HBG1399; d, HBG1793; e, HBG1802; f, HBG1791; g, HBG1777; h, HBG1395; i, HBG1954; j, HBG1982; k, HBG1855; 1, HBG1853. Reproduced with permission from Magnolia Press. 


\section{FIGURES}

\section{Figure 1.}
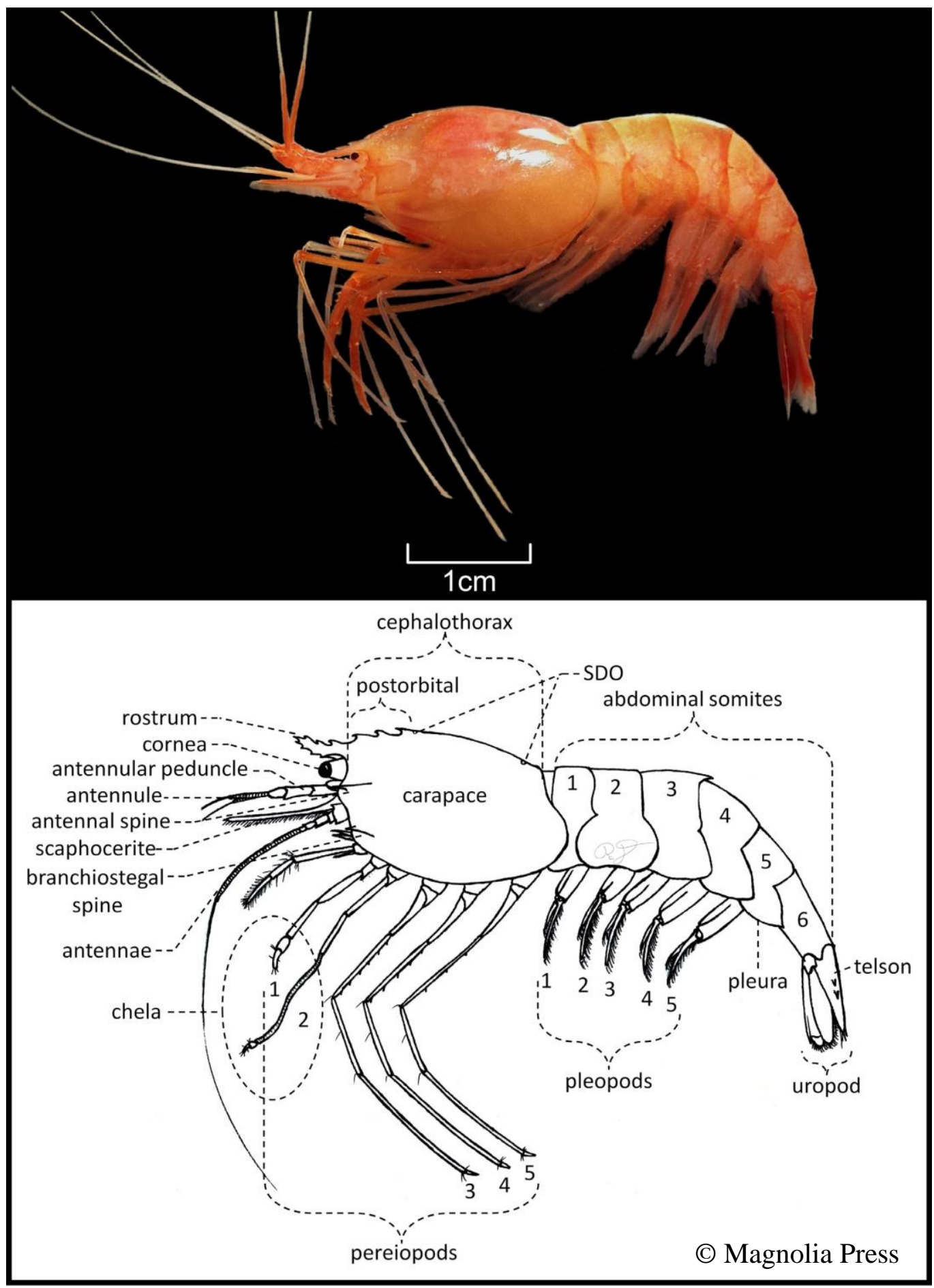
Figure 2.

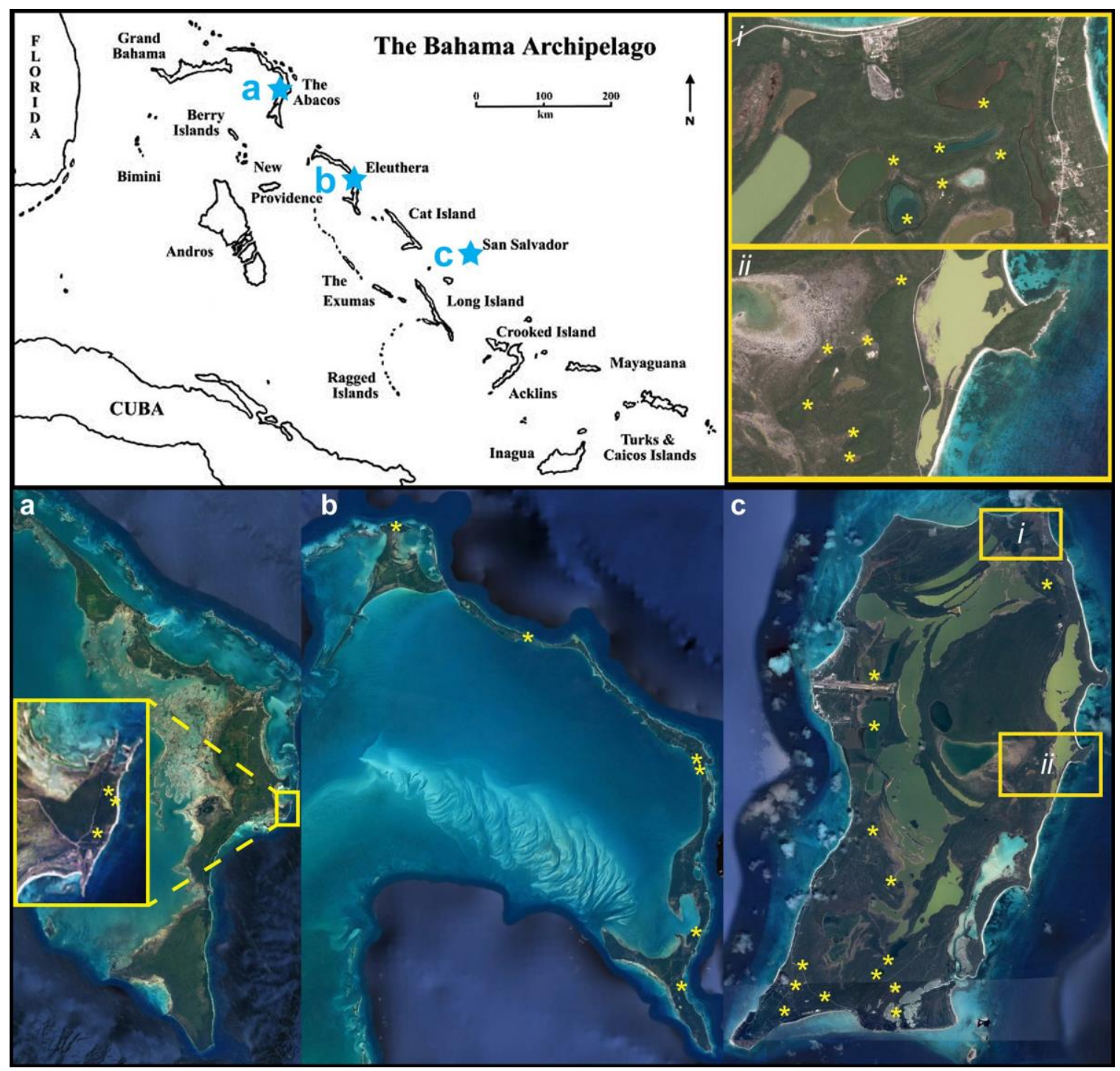

(C) Magnolia Press 
Figure 3.

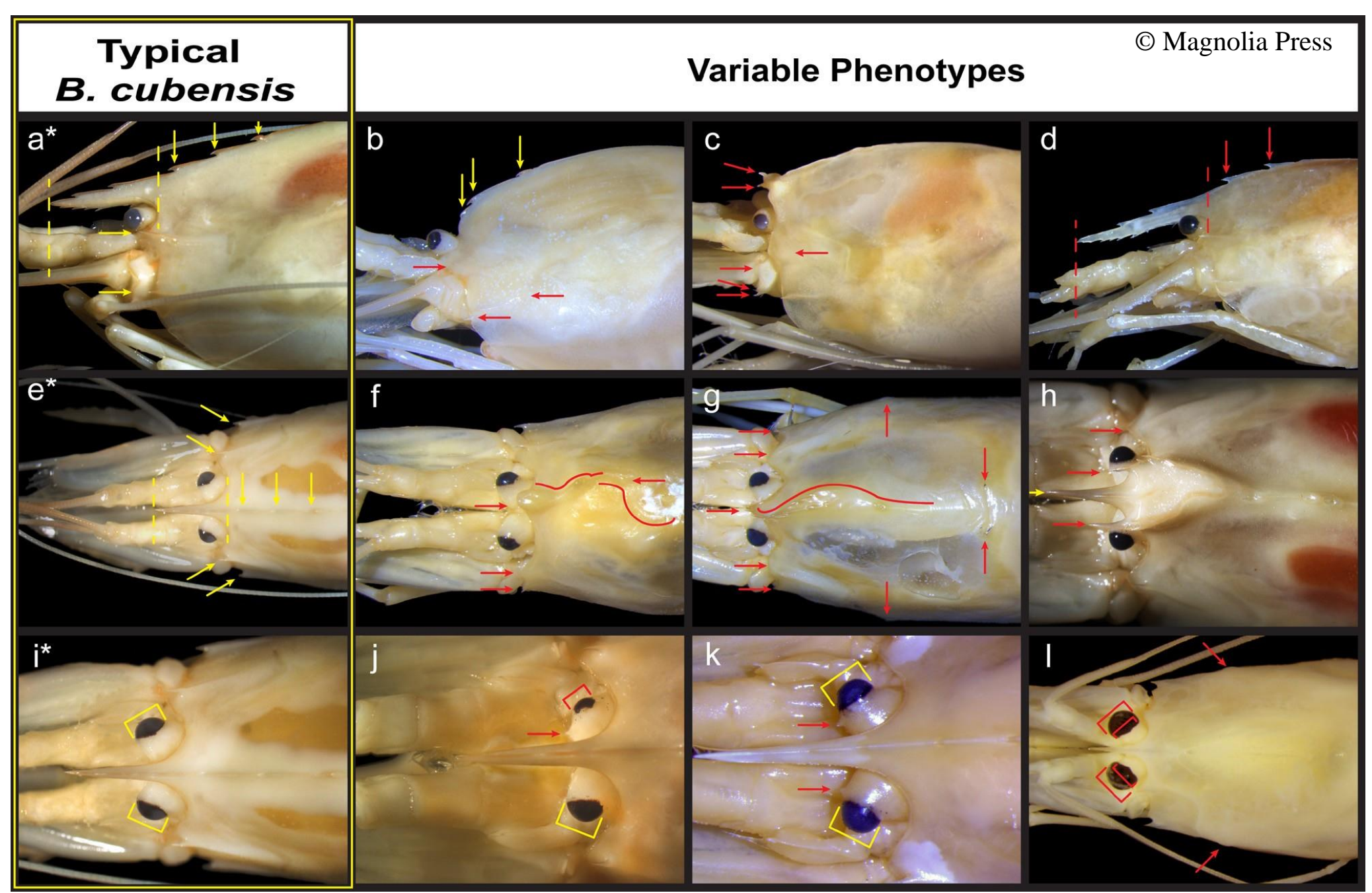


Figure 3 con't.

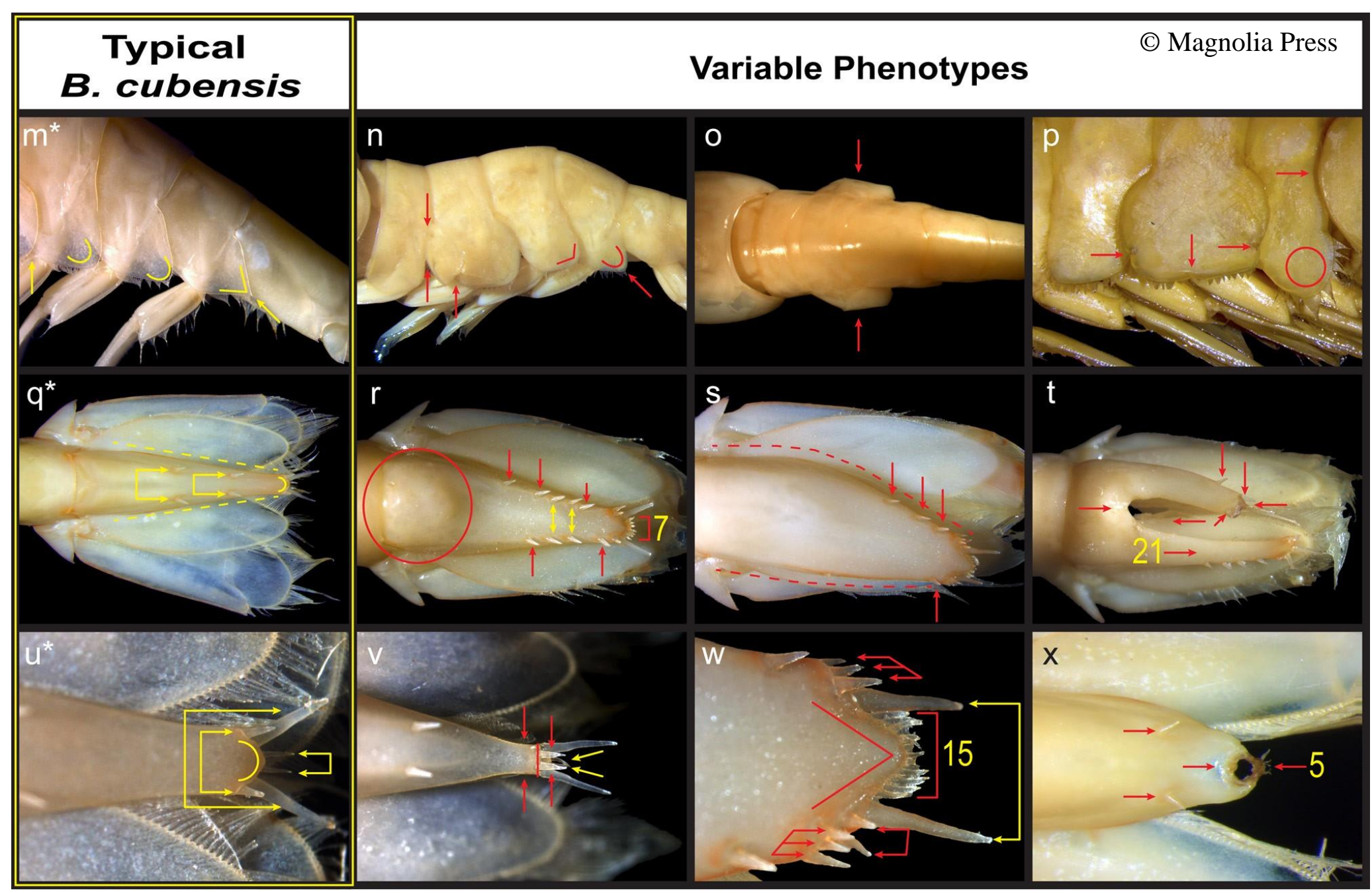


Figure 4.

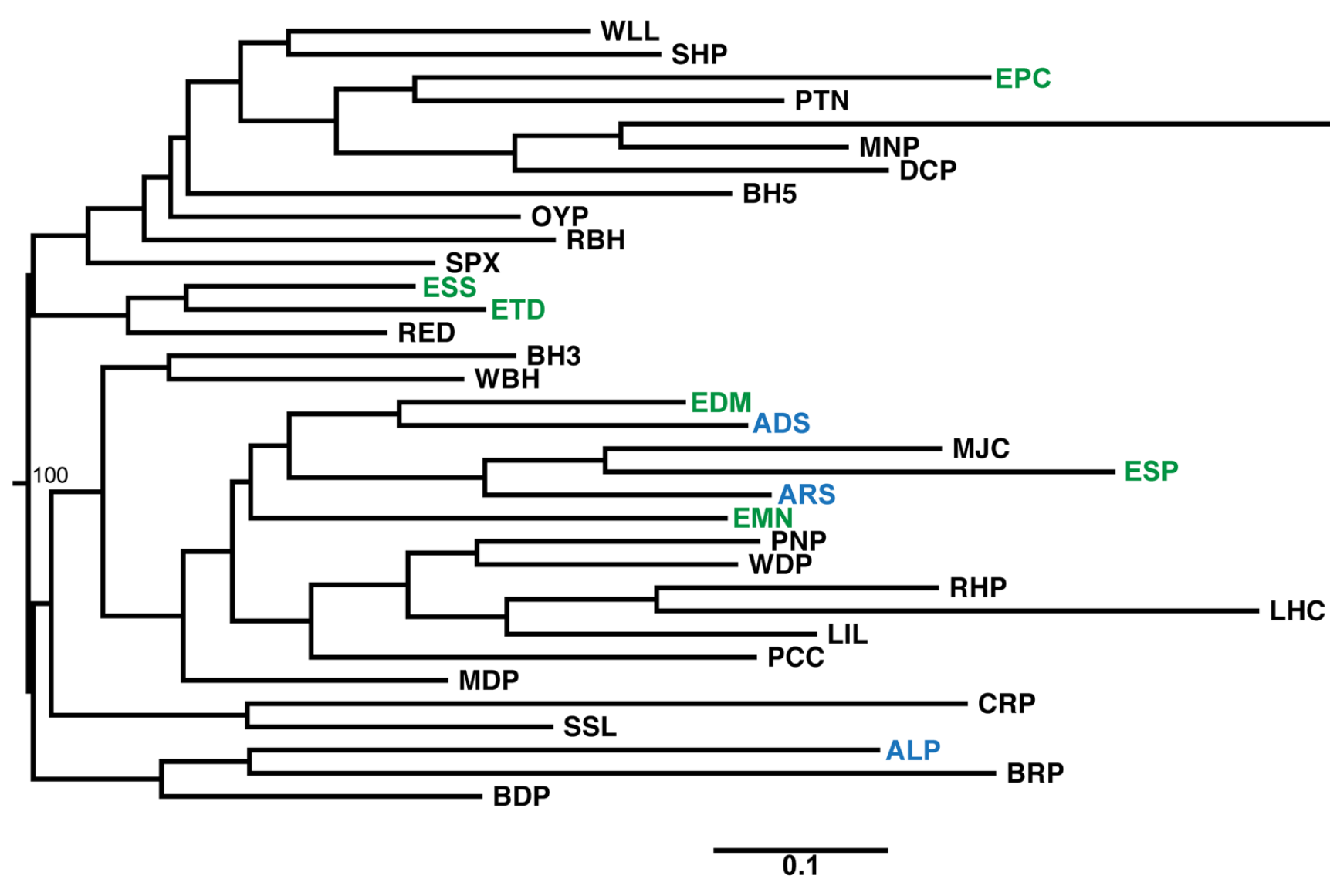

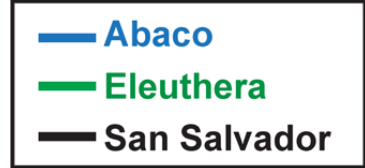

(C) Magnolia Press 
Figure 5.

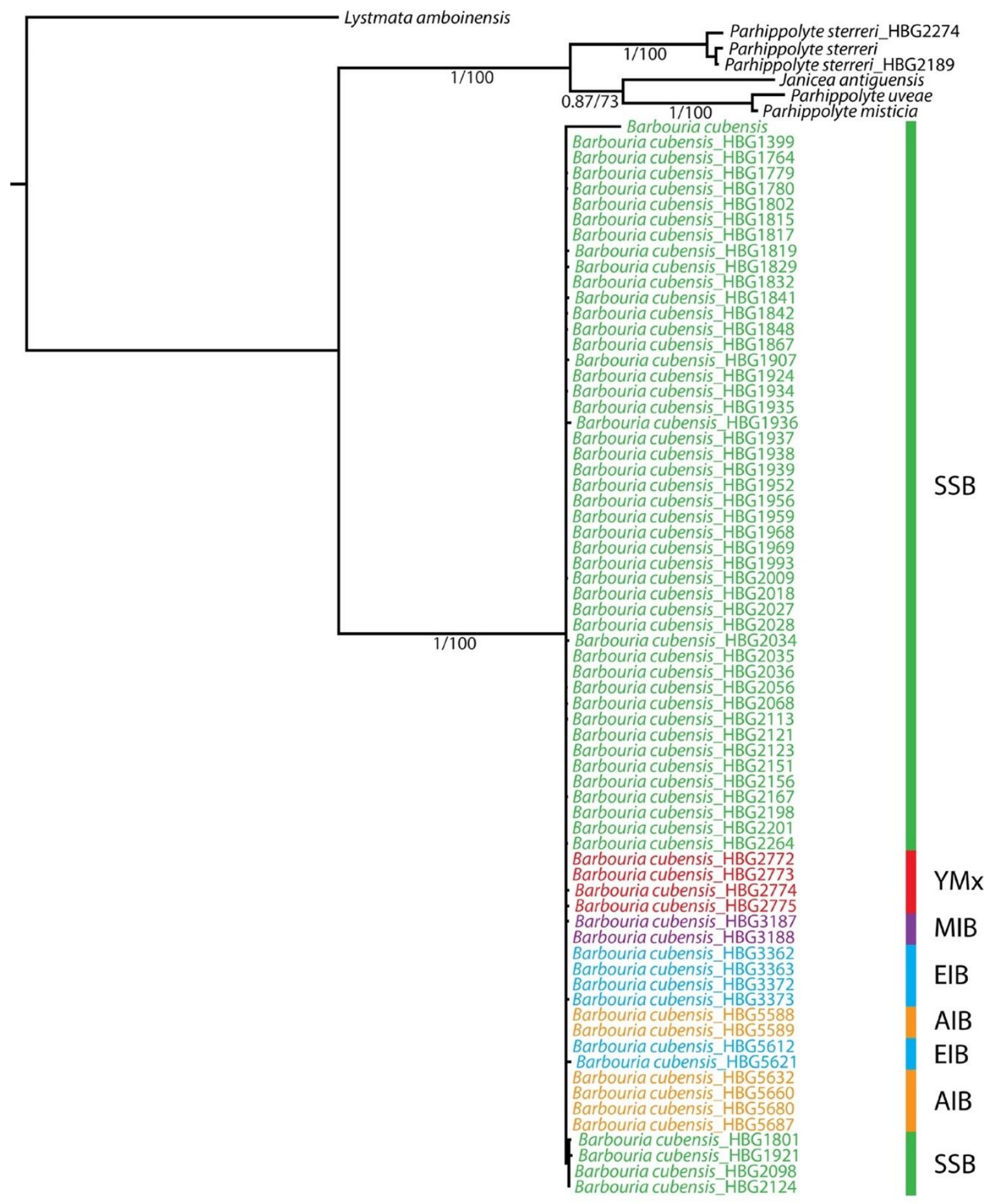


SUPPLEMENTAL FIGURES

Figure S1.

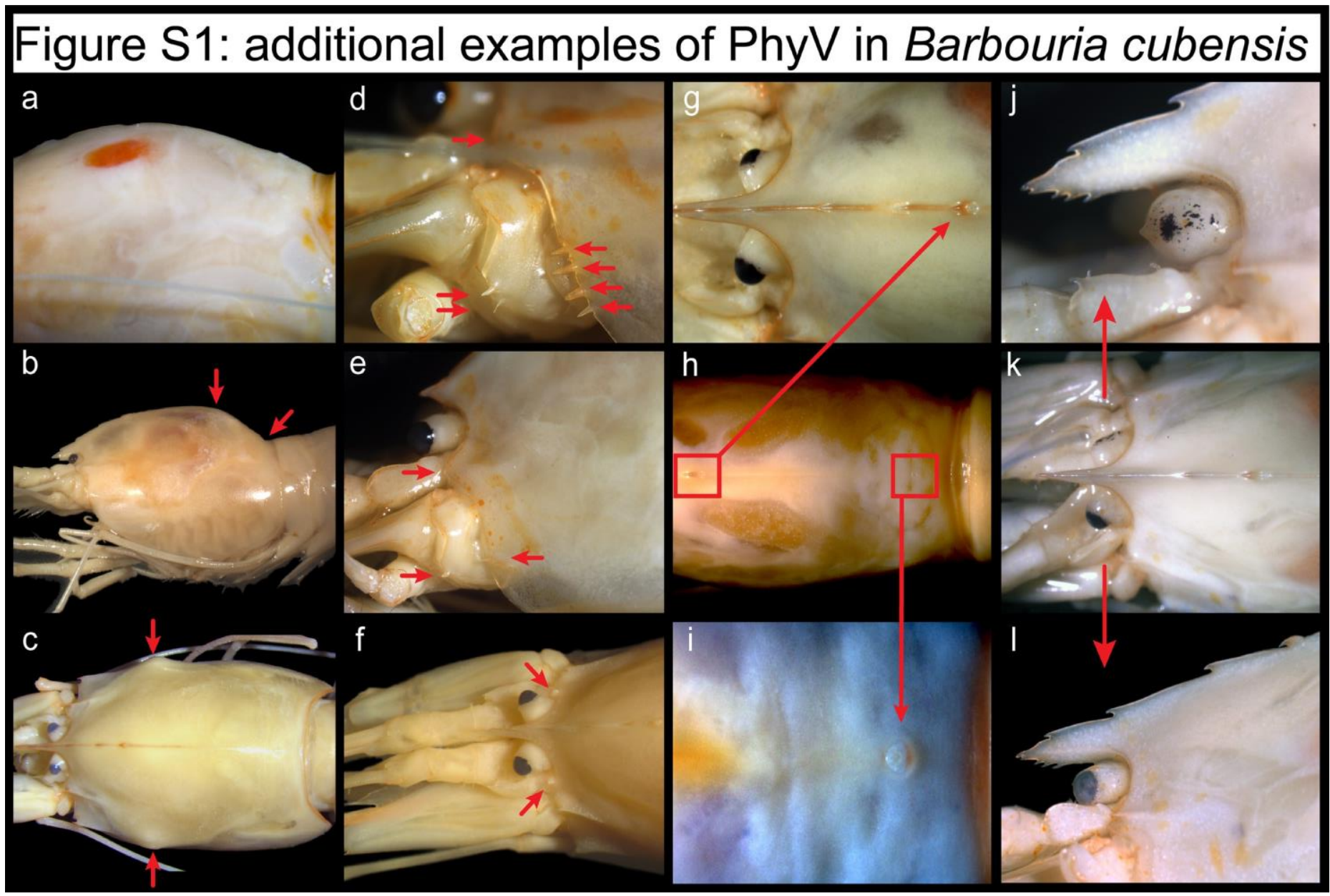

(C) Magnolia Press 
Figure S2.

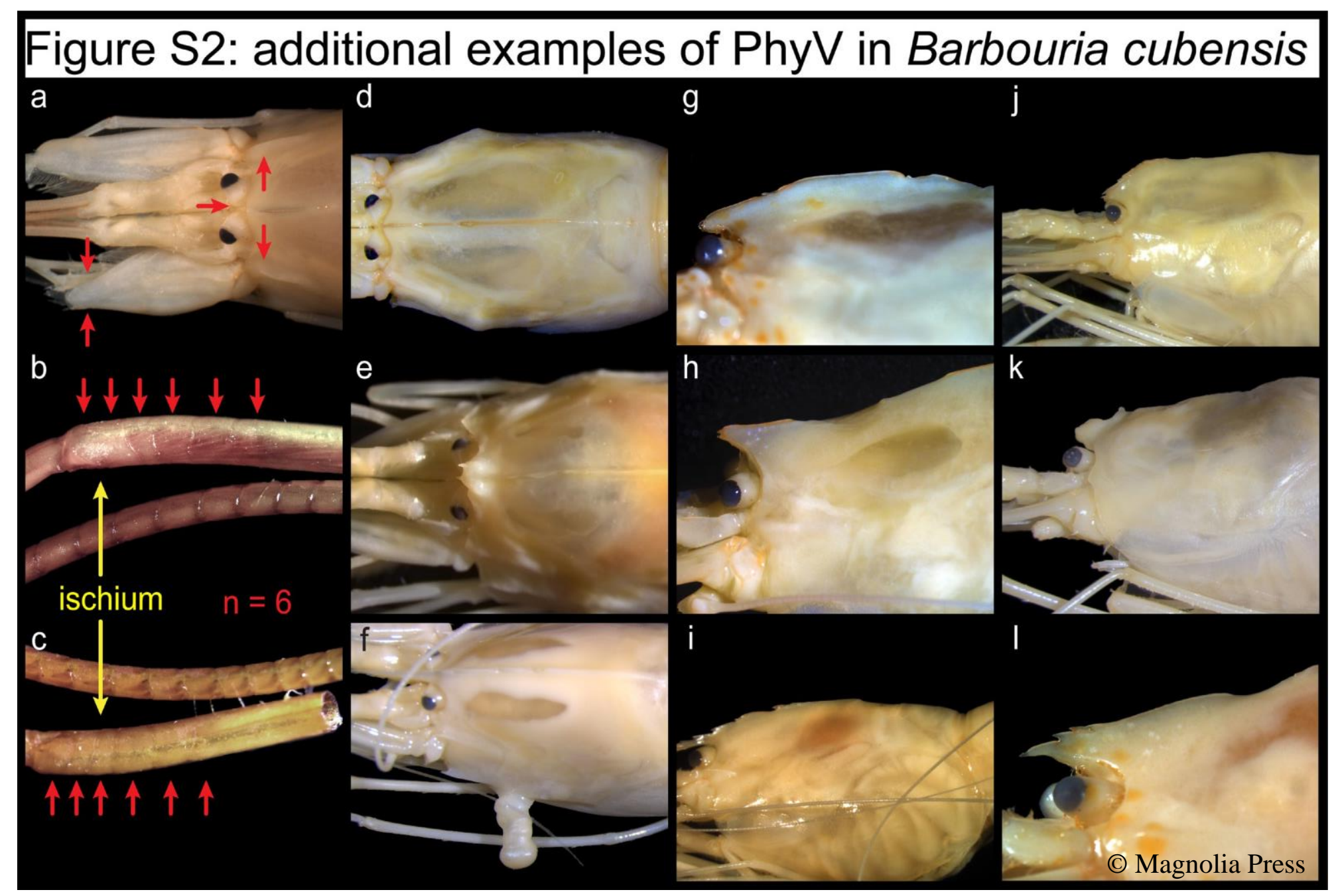


Figure S3.

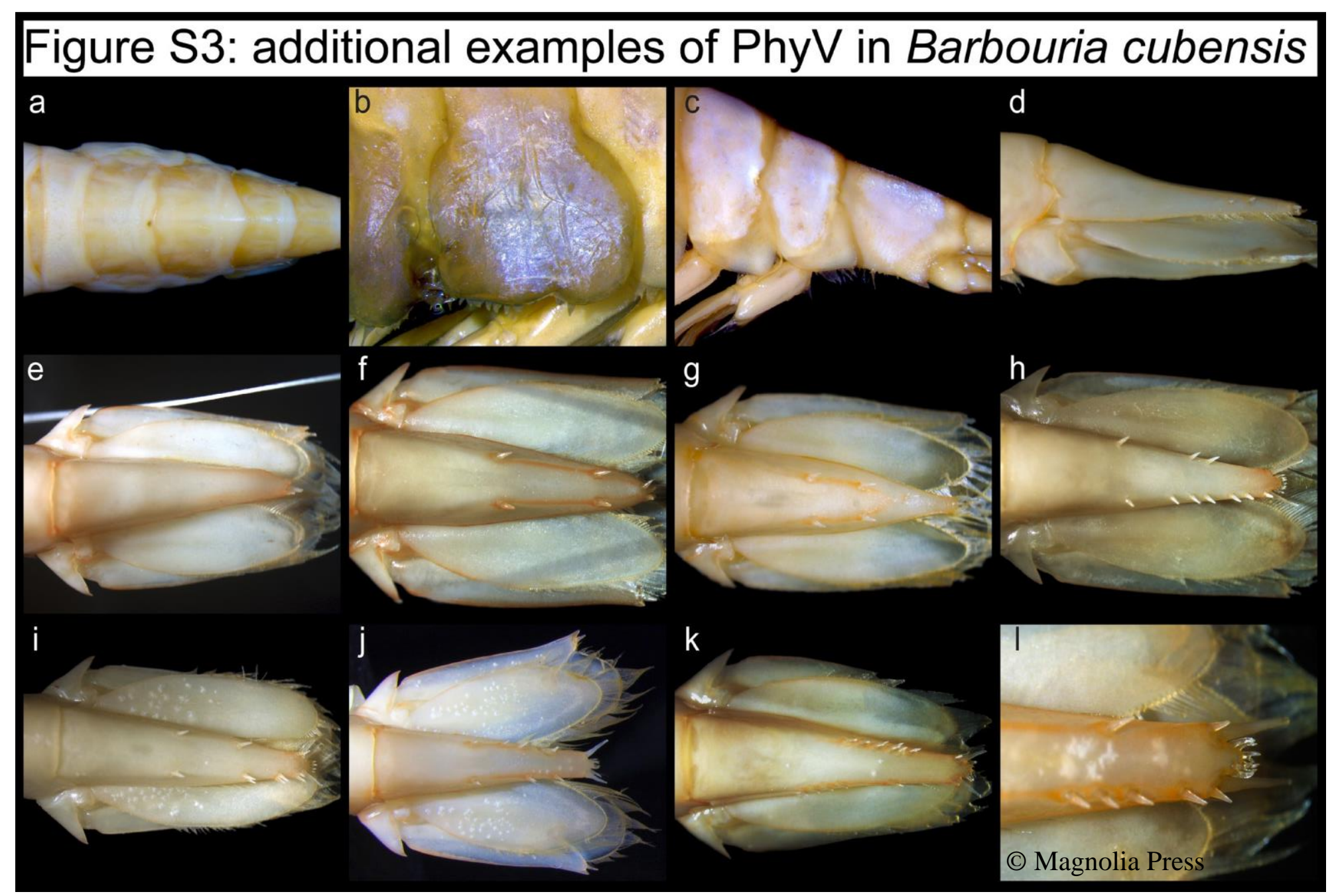


CHAPTER III

NOTES ON THE BEHAVIOR AND FIRST RECORDS OF THREE ENIGMATIC ANCHIALINE SHRIMPS (DECAPODA: CARIDEA: BARBOURIIDAE,

PALAEMONIDAE) IN THE BAHAMAS 


\begin{abstract}
Barbouria cubensis (von Martens, 1872), Parhippolyte sterreri (Hart \& Manning, 1981) (Barbouriidae) and Macrobrachium lucifugum Holthuis, 1974 (Palaemonidae) are recorded for the first time from anchialine systems on Acklins Island, Bahamas. Seventytwo individuals of B. cubensis, 29 of P. sterreri, and nine of M. lucifugum were collected in July 2017 from five sites across the island. We also report on observations of behavior for all three species during collection and of B. cubensis monitored in a laboratory setting over a two-year period.
\end{abstract}

\title{
INTRODUCTION
}

Anchialine systems are comprised of landlocked bodies of water with subterranean connections to the surrounding ocean that permit tidally driven water exchange (Bishop et al., 2015). Members of the family Barbouriidae Christoffersen, 1987 are globally distributed along tropical latitudes and are mostly endemic to anchialine systems (De Grave et al., 2014). The family consists of four genera, Barbouria, Calliasmata, Janicea, and Parhippolyte. Macrobrachium Spence Bate, 1868, is a species-rich genus of the family Palaemonidae Rafinesque, 1815 widely distributed in bodies of freshwater across tropical and subtropical latitudes (Holthuis, 1980; Vera-Silva et al., 2016). Some palaemonids, such as M. lucifugum Holthuis, 1974, are sometimes found in anchialine systems and coastal freshwater sink holes (Hobbs, 1994; Komai \& Fujita, 2005).

It is common for different species of Barbouriidae to inhabit the same locality (Hart \& Manning, 1981). Such cohabitation has previously been observed in anchialine caves in Bermuda and in Exuma and San Salvador islands in the Bahamas (Hart \& 
Manning, 1981; Botosaneanu \& Iliffe, 1999; Ditter et al., 2015). Barbouria cubensis von Martens, 1872 and Parhippolyte sterreri Hart \& Manning, 1981 are anchialine species that lack many troglomorphic characteristics associated with cave dwelling organisms such as the absence of pigmentation, reduced or absent eyes, cuticular structural reduction, and the elongation of sensory and ambulatory appendage (Holthuis, 1963; Turk et al., 1996; Lamoreux, 2004; Bishop \& Iliffe, 2012; Friedrich, 2013; Pérez-Moreno et al., 2017).

Barbouria cubensis has been reported from Cuba and the islands of Abaco, Exuma, Mayaguana, Grand Bahama, and San Salvador in the Bahamas, Providenciales in the Caicos Islands, Bermuda, Jamaica, Cayman Brac in the Cayman Islands, and in the Yucatan Peninsula (Hobbs et al., 1977; Manning \& Hart, 1984; Manning et al., 1985; Bishop \& Iliffe, 2012; Ditter et al., 2015). Parhippolyte sterreri is known to occur in Bermuda, the Yucatán Peninsula, and Andros, Exuma, Grand Bahama, and San Salvador, Bahamas (Hart \& Manning, 1981; Manning et al., 1985; Kensley, 1988; Wicksten, 1996; Ditter et al., 2015; M. Brooks, unpublished data). Despite their abundance across the tropical western Atlantic, little is known about the biology of these two species, with only anecdotal observations of their behavior reported. There is so far only one study comparing physiological differences between populations of B. cubensis (Bishop \& Iliffe, 2012). Macrobrachium lucifugum has previously been reported from Bonaire, Cuba, Curaçao, the Dominican Republic, Grand Bahama, Jamaica and Puerto Rico (Holthuis, 1974; Chace, 1975; Hobbs, 1994; De Grave \& Fransen, 2011).

We report on the first occurrence of Barbouria cubensis, Parhippolyte sterreri, and Macrobrachium lucifugum in the anchialine pools of Acklins Island, Bahamas. In 
addition to these first records, we discuss observations made for these species during collection as well as the behavior of $B$. cubensis in its natural habitat and in a laboratory setting.

\section{MATERIALS AND METHODS}

\section{SPECIMEN COLLECTION}

Seventy-two specimens of B. cubensis, 29 of P. sterreri, and nine of M. lucifugum were collected on Acklins Island, Bahamas $\left(22.3658^{\circ} \mathrm{N}, 74.0535^{\circ} \mathrm{W}\right)$ in July 2017. Specimens were collected from Big Pond, Harbour Hill Cave ("Darling's Cave"), Harbour Hill Cenote, Flamingo Pond, Nibbles Cave, Red Lantern Cave, and Student Pond (Fig. 1). Specimens were captured using a baited minnow trap deployed near the mouth of the conduit while snorkeling, or by hand. Specimens were preserved in 95-100\% ethyl alcohol or RNAlater (Sigma-Aldrich, St. Louis, MO, USA) on site or kept alive until they could be properly processed. Specimens were transferred to the Florida International University Crustacean Collection (FICC) located on the Biscayne Bay campus, North Miami, FL, USA after preservation.

Barbouria cubensis was captured from Big Pond, Flamingo Pond, Nibbles Cave, Red Lantern Cave, and Student Pond (Fig. 1), P. sterreri from Flamingo Pond, and $M$. lucifugum was from Harbour Hill and Red Lantern cave, juveniles observed in a freshwater cenote (Harbour Hill Cenote) $150 \mathrm{~m}$ north of the cave entrances. We noted that B. cubensis collected alongside $M$. lucifugum were smaller in size than those found at other sites. 


\section{BEHAVIORAL OBSERVATIONS}

Previously collected from San Salvador, Bahamas, 10 B. cubensis were used for behavioral observations. Eight individuals were paired and placed into four 191 (5 gal.) aquaria and two were isolated in two separate aquaria to serve as the control groups. The six aquaria were placed in a light controlled environment. Each aquarium contained one limestone shelter to mimic cave substratum to recreate the natural habitat as best as possible. Each aquarium was equipped with bubble filters, and timers were utilized to control the day/night cycles as follows: $2 \mathrm{~h}$ of indirect light, $8 \mathrm{~h}$ of direct light, $2 \mathrm{~h}$ of indirect light, and $12 \mathrm{~h}$ of dark. Red LED lights were installed to observe specimens during the night cycle.

Water was changed every other day using fresh filtered seawater from Biscayne Bay. Water quality parameters were monitored daily to maintain optimal water quality. Specimens were fed frozen brine shrimp daily. Noteworthy behavior was digitally recorded using a GoPro Hero2 and any exuvia recovered were preserved in 70\% ethyl alcohol.

\section{RESULTS AND DISCUSSION}

The presence of B. cubensis, P. sterreri, and M. lucifugum on Acklins Island, Bahamas represents minor range extensions for all three species (Fig. 2). Barbouria cubensis has the widest distribution on Acklins, being found in all sampling sites except for Harbour Hill Cave. As on San Salvador Island, P. sterreri is present only found on the southern portion of the island, possibly indicating that this species is a recent arrival due to its limited distribution on the island compared to B. cubensis (Ditter et al., 2015). 
Parhippolyte sterreri is present in other anchialine pools on southern Acklins Island, but these sites were not sampled. Macrobrachium lucifugum is limited to the northeastern portion of the islands (Fig. 1). Juvenile M. lucifugum were only observed in one freshwater cave (Fig. 1a), and adults were only collected in two marine caves (Fig. 1b, c). Many species of Macrobrachium are amphidromous, migrating between freshwater and saltwater habitats as part of their life history (Bauer \& Delahoussaye, 2008). Harbour Hill and Red Lantern caves are the only localities found in close proximity to a nonephemeral surface freshwater feature on Acklins Island. It is likely that the distribution of juvenile and adult $M$. lucifugum indicates subterranean connections between these localities because of its amphidromous life history. Alvarez et al. (2004) reported observing B. cubensis from Jumbey Hole cave; however, the cave was found to be a dry cave. There is no evidence that Jumbey Hole is or was an anchialine cave in recent history and island residents indicated that it has always been a dry cave.

\section{FIELD OBSERVATIONS}

The number of shrimps in anchialine pools are most abundant during high tide and absent during low tide. The presence or absence of shrimp in surface pools appears to be tidally driven. Barbouria cubensis, $P$. sterreri, and M. lucifugum began migrating into surface waters shortly after the start of flood tides and retreating during ebb tides. Further studies are necessary to understand the possible physiological mechanisms and environmental cues underlying this behavior, which may also further the understanding of the evolution of anchialine organisms. No remarkable agonistic behaviors were detected when $B$. cubensis and $P$. sterreri were observed in the same locality or housed in the same 
aquarium. When housed together for an extended period of time, B. cubensis mirrored the coloration of $P$. sterreri. This was done by increasing the intensity of white coloration along the joints of pereiopods $3-5$ and expanding the white spots on the posterior surface of the uropodal exopods and the sixth abdominal somite (Fig. 2b). When $B$. cubensis and M. lucifugum were observed in the same locality, B. cubensis avoided $M$. lucifugum. Barbouria cubensis and M. lucifugum could not be housed in the same aquarium due to the aggressive behavior of M. lucifugum. Barbouria. cubensis and $M$. lucifugum also exhibited no flight response to the presence of human observers, and often boldly foraged on the observers. Parhippolyte sterreri stayed deeper within the conduits and retreated in the presence of observers.

\section{LABORATORY OBSERVATIONS}

Barbouria cubensis was been found to exhibit phenotypic hypervariation (PhyV); defined as the presence of extensive morphological variation that far exceeds variation described in previous records and limits the usefulness of traditional taxonomic identification methods (Ditter et al., 2019). Our initial observations showed the presence of PhyV in captive individuals of $B$. cubensis and exuvia from each specimen were examined monthly to determine if PhyV was retained after Ecdysis. If PhyV was lost after ecdysis it would possibly indicate physical trauma as a source of PhyV. This was not the case as all individuals retained identical variations over the course of two years in captivity, and no additional morphological variations were observed in any individuals. To our knowledge, the retention of extensive morphological variation has only been reported over the course of 130 d in Palaemon longirostris (Béguer et al., 2010). 
The color of $B$. cubensis has been described to range from white and nearly transparent to deep red or crimson (Hobbs et al., 1977). Prior to light exposure, individuals appear nearly translucent (Fig. 3A), turning light to dark red within 4 min after exposure to full-spectrum light (Fig. 3B). Once returned to darkness, individuals lose color within $15 \mathrm{~min}$. As ecdysis neared, the degree of color change in response to light decreased. When exposed to only blue light (455 nm) individuals of B. cubensis exhibited a flight response of erratic swimming seeking refuge. Individuals rapidly changed color from nearly translucent to deep red in the presence of light due to the presence of two types of chromatophores: smaller red and larger white (Fig. 4). Both types of chromatophores are distributed along the body and appendages. The white chromatophores are much larger and less abundant than the red chromatophores. The contrast in color change from pale to red decreased over a $30 \mathrm{~d}$ period. Once color change could no longer be detected, ecdysis occurred within $48 \mathrm{~h}$. The increasingly red coloration of individuals appears to be a strong indicator for ecdysis.

Paired B. cubensis were highly active, either swimming or walking around the substrate, and cleaning themselves. Individuals were able to locate and consume food within 1 min. This species also exhibited agonistic behavior by means of antennal fencing (Dunham, 1972). Caridean shrimps have been found to behave aggressively to retain access to limited space, food, and potential mates (Ra'anan \& Sagi, 1985; Karplus \& Harpaz, 1990; Correa \& Thiel, 2003). When not active, B. cubensis hid underneath the limestone shelters or the water filter. Isolated individuals exhibited behavior that was unlike their paired counterparts. They were less active, remaining underneath their shelters most of the time and taking 2-6 min to locate and consume their food. This may 
be a possible explanation for the decreased activity and feeding response of isolated specimens.

Habitat destruction is a serious threat to the biodiversity of anchialine habitats (Culver \& Sket, 2000; Iliffe \& Kornicker, 2009). Many caves have already been altered or destroyed by pollution and development, and it is essential to document the distribution of anchialine organisms as their habitats are continually altered. The IUCN (2019) lists B. cubensis and P. sterreri as critically endangered, and $M$. lucifugum as least concern, but we believe reassessment of $M$. lucifugum would change its status to critically endangered (Iliffe, 1996a; Illiffe, 1996b; De Grave, 2013). Many unanswered questions about the dispersal, biology, and life history of anchialine organisms remain.

\section{ACKNOWLEDGEMENTS}

We would like to thank Drs. Eric S. Cole and John E. Mylroie for their valuable feedback and assistance. We are also thankful to Alexio Brown and Dr. Jocelyn Curtis-Quick for their feedback on the behavioral portion of the study. We would also like to thank the anonymous reviewers for their comments and feedback. Funding was provided by Florida International University. This is contribution 145 from the Center for Coastal Research in the Institute of Water and Environment at Florida International University.

\section{REFERENCES}

Alvarez, F., Villalobos, J.L. \& Iliffe, T.M. 2004. A new species of Agostocaris (Caridea: Agostocarididae) from Acklins Island, Bahamas. Proceedings of the Biological Society of Washington, 117: 368-376. 
Bauer, R.T. \& Delahoussaye, J. 2008. Life history migrations of the amphidromous river shrimp Macrobrachium ohione from a continental large river system. Journal of Crustacean Biology, 28: 622-632.

Béguer, M., Feuillassier., L., Elie, P., Boët, P. \& Giradin, M. 2010. Exoskeletal deformities in Palaemonidae: are they a threat to survival? Marine Environmental Research, 69: 109-117.

Bishop, R.E. \& Iliffe, T.M. 2012. Ecological physiology of the anchialine shrimp Barbouria cubensis: a comparison of epigean and hypogean populations. Marine Biodiversity, 42: 303-310.

Bishop, R.E., Humphreys, W.F., Cukrov, N., Žic, V., Boxshall, G.A., Cukrov, M., Iliffe, T.M., Kršinić, F., Moore, W.S., Pohlman, J.W. \& Sket, B. 2015. 'Anchialine' redefined as a subterranean estuary in a crevicular or cavernous geological setting. Journal of Crustacean Biology, 35: 511-514.

Botosaneanu, L. \& Iliffe, T.M. 1999. On four new stygobitic cirolanids (Isopoda: Cirolanidae) and several already described species from Mexico and the Bahamas. Bulletin de l'Institut Royal des Sciences Naturelles de Belgique, Biologie, 69: 93-123.

Chace, F.A. Jr. 1975. Cave shrimps (Decapoda: Caridea) from the Dominican Republic. Proceedings of the Biological Society of Washington, 88: 29-44.

Correa, C.R. \& Thiel, M.A. 2003. Mating systems in caridean shrimp (Decapoda: Caridea) and their evolutionary consequences for sexual dimorphism and reproductive biology. Revista Chilena de Historia Natural, 76: 187-203.

Culver, D.C. \& Sket, B. 2000. Hotspots of subterranean biodiversity in caves and wells. Journal of Cave and Karst Studies, 62: 11-17.

De Grave, S. 2013. Macrobrachium lucifugum. The IUCN Red List of Threatened Species: e.T198104A2512014. http://dx.doi.org/10.2305/IUCN.UK.20131.RLTS.T198104A2512014.en.

De Grave, S. \& Fransen, C.H.J.M. 2011. Carideorum Catalogus: The Recent Species of the Dendrobranchiate, Stenopodidean, Procarididean and Caridean Shrimps (Crustacea: Decapoda). Zoologische Mededelingen, 85: 195-589.

De Grave, S., Li, C.P., Tsang, L.M., Chu, K.H. \& Chan, T.Y. 2014. Unweaving hippolytoid systematics (Crustacea, Decapoda, Hippolytidae): resurrection of several families. Zoologica Scripta, 43: 496-507. 
Ditter, R.E., Goebel, A.M. \& Erdman, R.B. 2015. First record of the anchialine shrimp Parhippolyte sterreri (Decapoda, Barbouriidae) from San Salvador Island, Bahamas, with observations on Barbouria cubensis. Marine Biodiversity Records, 8: e46 [doi.org/10.1017/S1755267215000196].

Ditter, R. E., Erdman, R. B., Goebel, A. M., and Bracken-Grissom, H. D. 2019. Widespread phenotypic hypervariation in the enigmatic anchialine shrimp Barbouria cubensis (Decapoda: Barbouriidae). Zootaxa, 4648(1): 1-26.

Dunham, P.J. 1972. Some effects of group housing upon the aggressive behavior of the lobster Homarus americanus. Journal of Fisheries Research Board of Canada, 29: 598-601.

Friedrich, M. 2013. Biological clocks and visual systems in cave-adapted animals at the dawn of speleogenomics. Integratic and Comparative Biology, 53: 50-67.

Hart, C.W. Jr, Manning, R.B. \& Iliffe, T.M. 1985. The fauna of Atlantic marine caves: evidence of dispersal by sea floor spreading while maintaining ties to deep waters. Proceedings of the Biological Society of Washington, 98: 288-92.

Hart, C.W. Jr \& Manning, R.B. 1981. The cavernicolous caridean shrimps of Bermuda (Alpheidae, Hippolytidae, and Atyidae). Journal of Crustacean Biology, 1: 44156.

Hobbs, H.H. III. 1994. Biogeography of subterranean decapods in North and Central America and the Caribbean region (Caridea, Astacidea, Brachyura). Hydrobiologia, 364: 1-143.

Hobbs, H.H. Jr., Hobbs, H.H. III \& Daniel, M.A. 1977. A review of the troglobitic decapod crustaceans of the Americas. Smithsonian Contribution to Zoology, 244: $1-183$.

Holthuis, L.B. 1963. On red coloured shrimps (Decapoda, Caridea) from tropical landlocked saltwater pools. Zoologische Mededelingen, 38: 261-279.

Holthuis, L.B. 1974. Subterranean Crustacea Decapoda Macrura collected by Mr. L. Botosaneanu during the 1973 Cuban-Roumanian Biospeleological expedition to Cuba. International Journal of Speleology, 6: 231-242.

Holthuis, L.B. 1980. Shrimps and prawns of the world. An annotated catalogue of species of interest to fisheries. FAO Species Catalogue. Vol. 1. FAO Fisheries Synopsis, 125: $1-271$. 
Illiffe, T.M. 1996a. Barbouria cubensis. The IUCN Red List of Threatened Species: e.T2559A9454288. http://dx.doi.org/10.2305/IUCN.UK.1996.RLTS.T2559A9454288.en.

Illiffe, T.M. 1996a. Somersiella sterreri. The IUCN Red List of Threatened Species: e.T20371A9192483. http://dx.doi.org/10.2305/IUCN.UK.1996.RLTS.T20371A9192483.en.

Iliffe, T.M. \& Kornicker, L.S. 2009. Worldwide diving discoveries of living fossil animals from the depths of anchialine and marine caves. Smithsonian Contributions to the Marine Sciences, 38: 269-280.

Karplus, I. \& Harpaz, S. 1990. Preliminary observations on behavioral interactions and distribution patterns of freshwater prawns Macrobrachium rosenbergii under semi-natural conditions (Decapoda, Caridea). Crustaceana, 59: 193-203.

Kensley, B. 1988. New species and records of cave shrimps from the Yucatan Peninsula (Decapoda: Agostocarididae and Hippolytidae). Journal of Crustacean Biology, 8: 688-99.

Lamoreux, J. 2004. Stygobites are more wide-ranging than troglobites. Journal of Cave and Karst Studies, 66: 18-19.

Manning, R.B. \& Hart, C.W. Jr. 1984. The status of the hippolytid shrimp genera Barbouria and Ligur (Crustacea: Decapoda): a reevaluation. Proceedings of the Biological Society of Washington, 97: 655-665.

Martens, E., von. 1872. Über cubanische Crustaceen nach den Sammlungen Dr. J. Gundlach's. Archiv für Naturgeschichte, 38: 77-147.

Pérez-Moreno, J.L., Balázs, G., Wilkins, B., Herczeg, G. \& Bracken-Grissom, H.D. 2017. The tole of isolation on contrasting phylogeographic patterns in two cave crustaceans. BMC Evolutionary Biology, 17: 247.

Ra'Anan, Z. \& Sagi, A. 1985. Alternative mating strategies in male morphotypes of the freshwater prawn Macrobrachium rosenbergii (De Man). Biological Bulletin, 169: 592-601.

Spence Bate, C. 1868. On a new genus, with four new species, of freshwater prawns. Proceedings of the Zoological Society of London, 1868: 363-368.

Turk, S., Sket, B. \& Sarbu, S. 1996. Comparison between some epigean and hypogean populations of Asellus aquaticus (Crustacea: Isopoda: Asellidae). Hydrobiologia, 337: $161-170$. 
Wicksten, M.K. 1996. Parhippolyte cavernicola, new species (Decapoda: Caridea: Hippolytidae) from the tropical eastern Pacific, with taxonomic remarks on the genera Somersiella and Koror. Journal of Crustacean Biology, 16: 201-207.

Vera-Silva, A.L., Carvalho, F.L. \& Mantelatto, F.L. 2016. Distribution and genetic differentiation of Macrobrachium jelskii (Miers, 1877) (Natantia: Palaemonidae) in Brazil reveal evidence of non-natural introduction and cryptic allopatric speciation. Journal of Crustacean Biology, 36: 373-383.

\section{FIGURE CAPTIONS}

Figure 1. Map of Acklins, Bahamas adapted from Google Earth indicating the collection sites of Barbouria cubensis, Parhippolyte sterreri, and Macrobrachium lucifugum and the location of Jumbey Hole Cave. Magnified view of Harour Hill Cenote (A), Harbour Hill Cave (B), and Red Lantern Cave (D). Scale bar $=50 \mathrm{~m}$. This figure is available in color at Journal of Crustacean Biology online. Reproduced with permission of Oxford University Press.

Figure 2. Dorsal views of Barbouria cubensis (A), Parhippolyte sterreri (B), and Macrobrachium lucifugum $(\mathbf{C})$. Scale bar $=1 \mathrm{~cm}$. This figure is available in color at Journal of Crustacean Biology online. Reproduced with permission of Oxford University Press.

Figure 3. Left lateral view of an individual of Barbouria cubensis exhibiting color change before and after light exposure, being nearly translucent pale when not exposed to light, (A) and deep red/crimson after five minutes of exposure to direct light (B). Scale bar $=1 \mathrm{~cm}$. This figure is available in color at Journal of Crustacean Biology online. Reproduced with permission of Oxford University Press. 
Figure 4. Dorsal view of the cephalothorax of Barbouria cubensis cephalothorax (40x magnification) with distinct small red and large white chromatophores visible. Scale bar $=1 \mathrm{~mm}$. This figure is available in color at Journal of Crustacean Biology online. Reproduced with permission of Oxford University Press. 


\section{FIGURES}

\section{Figure 1.}

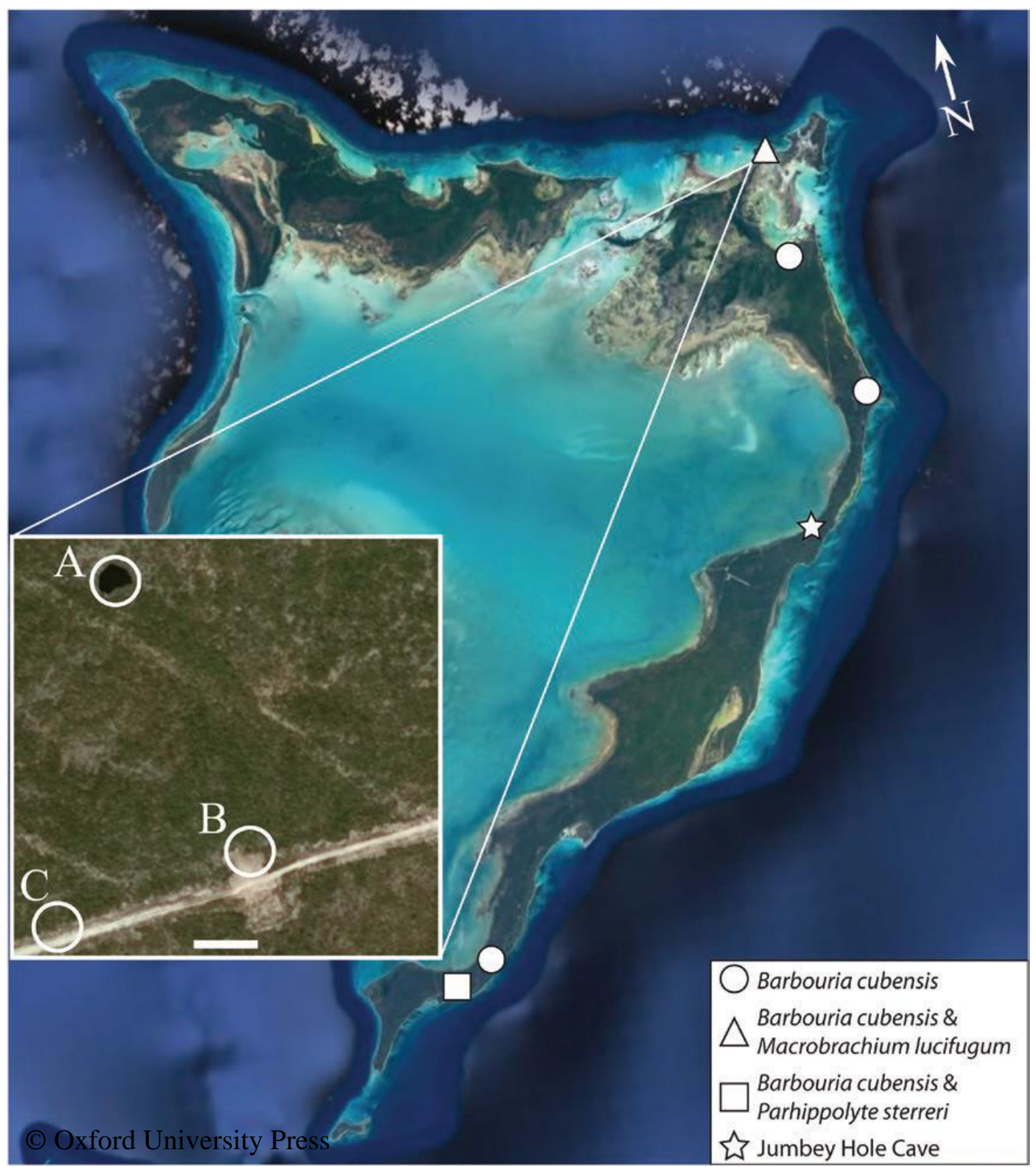


Figure 2.

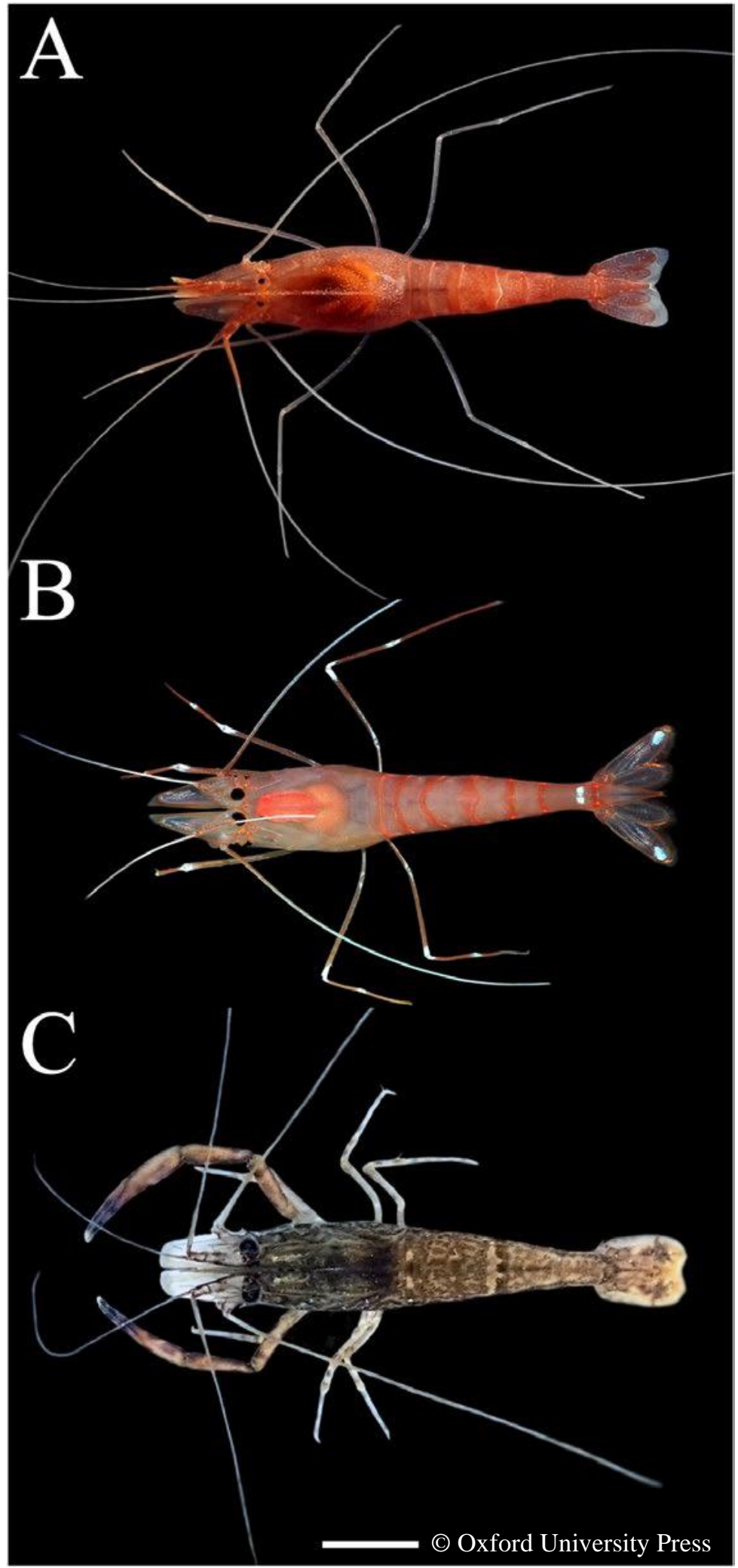


Figure 3.

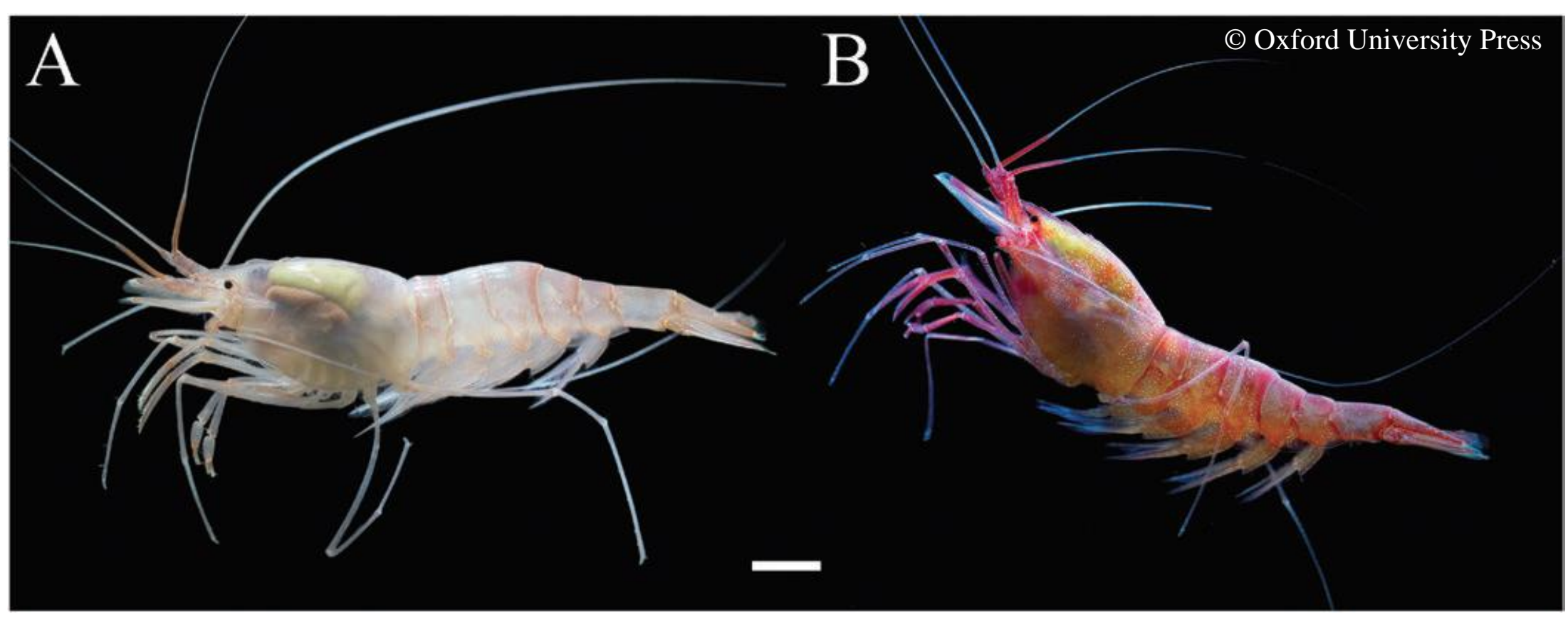


Figure 4.

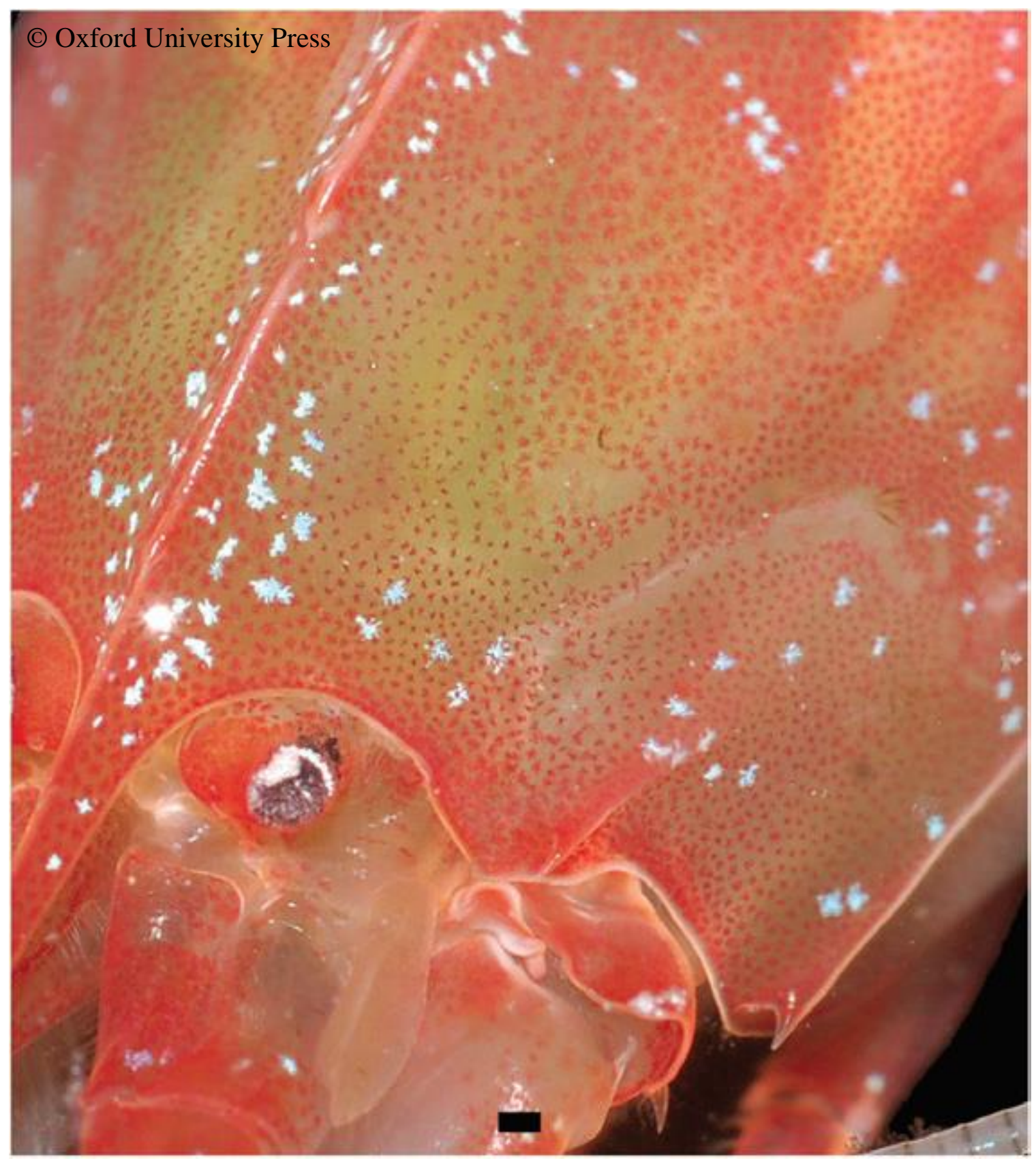




\section{CHAPTER IV}

ANCHIALINE ADJUSTMENTS: AN UPDATED PHYLOGENY AND

CLASSIFICATION FOR THE FAMILY BARBOURIIDAE CHRISTOFFERSEN, 1987

(DECAPODA: CARIDEA) 


\begin{abstract}
Barbouriidae Christoffersen, 1987 is a family comprised of 4 genera and 11 species of enigmatic shrimps restricted to anchialine or marine caves whose evolutionary history and relationships remain elusive. We investigated the evolutionary relationships among members of Barbouriidae with the inclusion of four genera and nine species, and newly collected material from Belize, the Bahamas, and the Yucatán Peninsula, Mexico. Phylogenetic analyses based on seven mitochondrial and nuclear gene regions and genetic distances calculated using partial $16 \mathrm{~S}$ gene regions have identified a need to revisit the relationships and classification within Barbouriidae. More specifically, we find evidence to suggest Janicea Manning \& Hart, 1984 as a junior synonym of Parhippolyte Borradaile, 1900, B. yanezi Mejía, Zarza \& López, 2008 as a synonym of Barbouria cubensis (von Martens, 1872), and define two new subfamilies, Calliasmatinae nov. and Barbouriinae Christoffersen, 1987. Included is a dichotomous key for the species of Barbouriidae that summarizes previous literature and includes new morphological characters. Our findings shed light on existing inaccuracies and gaps in molecular data from barbouriids. We also provide further clarity into evolutionary relationships among genera of Barbouriidae and their allies, suggesting phylogeographic divisions within the family. Our findings suggest an early Atlantic-Pacific divide among genera originating from a shallow-water reef ancestor.
\end{abstract}

\title{
INTRODUCTION
}

Anchialine pools are a common feature throughout the tropical western Atlantic, and are broadly defined as land-locked pools with limited tidal connections to adjacent marine 
water bodies through a complex network of subterranean conduits (Bishop et al., 2015). Anchialine systems are considered to be isolated due to their unique species assemblages and endemicity (Iliffe \& Kornicker, 2009; Becking et al., 2011; Pérez-Moreno et al., 2016). Barbouriidae Christoffersen, 1987 (Fig. 1) is a family of caridean shrimps that commonly inhabits anchialine or coastal caves along tropical latitudes (Fig. 2).

Barbouriidae is currently comprised of 4 genera and 11 species, but the genera within this family have undergone substantial revisions in recent years (Chace, 1972, 1997; Manning

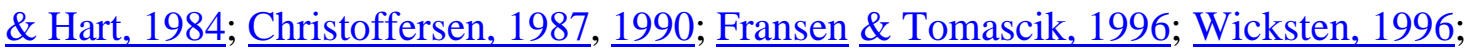

De Grave et al., 2014).

The evolutionary history of Barbouriidae remains unclear (De Grave et al., 2014). Members of this family had previously been classified as monotypic genera within

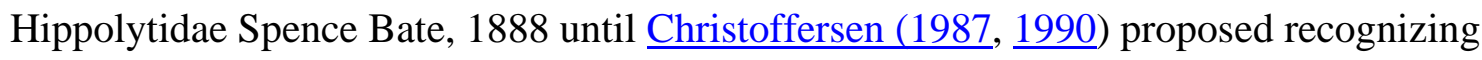
Barbouriidae as a family with six genera (Ligur $\underline{\text { Sarato, 1885; }}$; Barbouria $\underline{\text { Rathbun, 1912; }}$ Janicea Manning \& Hart, 1984; Parhippolyte Borradaile, 1900; Somersiella Hart \& Manning, 1981; and Koror Clark, 1989). Kemp (1914) synonymized Parhippolyte with Ligur without comment. Upon discovery of additional species with a multiarticulate carpus and propodus of the third to fifth pereiopods, Parhippolyte was removed from the synonymy of Ligur (Manning \& Hart, 1984). Ligur became a monospecific genus with the removal of $P$. uveae Borradaile, 1900 and was transferred from Hippolytidae upon the resurrection of Lysmatidae Dana, 1852 (Manning \& Hart, 1984; De Grave et al., 2014). The description of Koror misticius $\underline{\text { Clark, } 1989}$ and Somersiella sterreri Hart \& Manning, 1981 placed them within Hippolytidae, but a lack of morphological evidence at the genus level for both genera led them to be synonymized with Parhippolyte (Wicksten, 1996; 
Chace, 1997). With these exclusions and reclassifications, recent phylogenetic analyses have supported the recognition of the family Barbouriidae (Li et al., 2011; De Grave et al., 2014; Aznar-Cormano et al., 2015). The current classification of Barbouriidae includes two species of Barbouria (B. cubensis (von Martens, 1872)) and B. yanezi Mejía, Zarza \& López, 2008), one species of Janicea (J. antiguensis (Chace, 1972)), five species of Parhippolyte (P. cavernicola Wicksten, 1996; P. misticia (Clark, 1989); P. rukuensis Burukovsky, 2007; P. sterreri (Hart \& Manning, 1981); and P. uveae), and the most recent addition of three species of Calliasmata Holthuis, 1973 (C. nohochi EscobarBriones, Camacho \& Alcocer, 1997; C. pholidota Holthuis, 1973; and C. rimolii $\underline{\text { Chace, }}$ 1975). Barbouria cubensis and P. sterreri (listed as Somersiella sterreri) are listed as critically endangered on the IUCN Red List (Iliffe, 1996).

Although the genus Calliasmata is presently placed within Barbouriidae, De Grave et al. (2014) questioned the inclusion of this group within the family. Calliasmata lacks all of the defining characters shared by genera of Barbouriidae, including the unique subocular tooth posterodorsal to the orbital angle, which has been previously considered as a synapomorphy of the family (Clark, 1989; Chace, 1997; De Grave et al., 2014). Moreover, in spite of the troglodytic lifestyle of barbouriids, only Calliasmata exhibits characteristic adaptions of cave-dwelling animals, such as highly degenerate eyes (Pérez-Moreno et al., 2016). The conflicting morphology of Calliasmata with the other members of Barbouriidae further complicates the evolutionary history of this family, and Barbouriidae presently lacks an accurate formal description (see De Grave et al., 2014). 
We also revisited the placement of the monospecific genus Janicea among other barbouriids. Janicea has the broadest distribution of the Atlantic species, ranging from the Canary Islands, Bermuda, and the Yucatán Peninsula, Mexico (Manning \& Hart, 1984; Li et al., 2011). Janicea antiguensis (Chace, 1972) has a gill compliment similar to that of B. cubensis, but multiarticulation of the carpus and propodus of the third to fifth pereiopods and a cornea wider than the eyestalk suggest an affinity to Parhippolyte (Manning \& Hart, 1984). The first description of J. antiguensis placed it within Barbouria with the belief that Barbouria would eventually be synonymized with Ligur, but Janicea was later recognized as a monotypic genus (Chace, 1972; $\underline{\text { Buden \& }} \underline{\text { Felder, }}$ 1977; Manning \& Hart, 1984). The taxonomic uncertainty surrounding J. antiguensis justifies a closer examination of the phylogenetic placement of this species within Barbouriidae.

Barbouria yanezi Mejía, Zarza \& López, 2008 is the most recently described species of Barbouriidae and has only been reported from Cenote Tres Potrillos, Cozumel Island, Mexico (Mejía et al. 2008). Barbouria yanezi differs from Barbouria cubensis (von Martens, 1872) in the length and number of teeth of the rostrum, the length to width ratio of the scaphocerite, the proportions of the first and second pereiopod, the number of articulations of the carpus and ischium of the second pereiopod, and the length and terminal spines of the appendix masculina (Mejía et al., 2008). Barbouria cubensis has been more recently found to exhibit phenotypic hypervariation (PhyV), defined as the presence of extensive undescribed morphological variation at an uncommonly high frequency (Ditter et al., 2019). The differences that distinguish B. yanezi from $B$. cubensis fall within the range of morphological variations documented for B. cubensis 
from the Bahamas (Ditter ). In light of PhyV, the need to revisit the relationship between B. yanezi and B. cubensis using molecular tools is clear.

Although past molecular phylogenies have enhanced our understanding of barbouriid relationships, they are hindered by limited sampling across genera or incomplete genetic datasets (Fiedler et al., 2010; Li et al., 2011; Baeza, 2013; De Grave et al., 2014; Aznar-Cormano et al., 2015). Recent collections have allowed us to include nine species across all genera and provides further insight into the evolutionary relationships among these enigmatic crustaceans. We investigated the evolutionary relationships across current members of Barbouriidae with particular attention to the above-mentioned genera and species using multi-locus phylogenetic methods.

\section{MATERIAL AND METHODS}

SAMPLING

We selected 7 genera and 16 species to be included in the phylogenetic analysis of Barbouriidae, including all four currently recognized genera of the family Barbouriidae (Calliasmata, Barbouria, Parhippolyte and Janicea). Species of the closely related

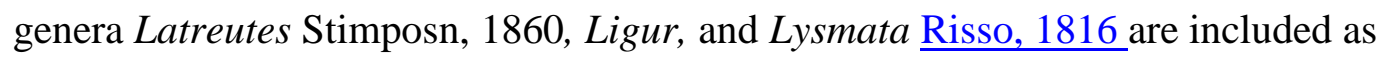
outgroups. Barbouria cubensis and P. sterreri were collected on the San Salvador, Bahamas using baited minnow traps between June 2014 and July 2015. Tissue samples of B. yanezi were provided by LMMO collected from Cenote Tres Potrillos, Cozumel, Mexico. Specimens of J. antiguensis and C. nohochi were donated to the Florida International Crustacean Collection (FICC) by Dr. Thomas Iliffe. Additional sequences for J. antiguensis and L. fucorum were generated from specimens housed in the FICC 
located on the Biscayne Bay Campus of Florida International University. Several specimens of Parhippolyte misticia were received as a loan from Dr. Tin-Yam Chan, National Taiwan Ocean University (NTOU) and several Parhippolyte uveae specimens were received as a loan from the Muséum national d'Histoire naturelle, Paris (MNHN). Parhippolyte cavernicola and additional specimens of $P$. uveae were received as loans from the Smithsonian Institution, United States National Museum of Natural History (NMNH). Attempts to generate additional sequences for L. ensiferus were unsuccessful. Loci were selected based on previous studies that confirm their utility in caridean phylogenetics (Bracken-Grissom et al., 2009a; Fiedler et al., 2010; Li et al., 2011; De Grave et al., 2014; Aznar-Cormano et al., 2015). To utilize taxa with sequences available in GenBank, loci were also selected so that individuals included in previous studies could be included. Loci included both protein coding and non-coding nuclear and mitochondrial gene regions. We generated 196 new sequences for seven partial gene regions from Barbouria cubensis, B. yanezi, Calliasmata nohochi, Parhippolyte sterreri, $P$. cavernicola, P. misticia, P. uveae, Janicea antiguensis, and Latreutes fucorum (Fabricius, $\underline{1798)}$.

\section{DNA EXTRACTION, PCR AND SEQUENCING}

Total genomic DNA was extracted from muscle tissue of the abdomen, antennule or the third to fifth pleopod using DNeasy® Blood and Tissue Kits (Qiagen, Valencia, CA, USA). For incomplete tissue digestions, $10 \mu \mathrm{l}$ of $10 \%$ DTT and $10 \mu \mathrm{l}$ Proteinase $\mathrm{K}$ was added, and samples incubated until complete digestion was achieved. Total genomic DNA quality was visualized using $2 \%$ agarose gels and concentration was measured 
using the Qubit dsDNA HS Assay kit on the Qubit 2.0 Fluorometer (Invitrogen, Carlsbad, CA, USA) according to manufacturer's instructions.

We selected two partial mitochondrial genes and five partial nuclear genes for their utility in studies of phylogeny and genetic diversity among decapods (Bracken $e t$ al., 2009b; Baeza, 2010; De Grave et al., 2014; Aznar-Cormano et al., 2015). The mitochondrial genes included the 16S large ribosomal subunit ( $\sim 50$ basepairs (bps)) and protein-coding cytochrome oxidase I ( 600 bps, COI). The nuclear genes included the 28S large ribosomal subunit ( $750 \mathrm{bps})$ and protein coding genes: phosphoenolpyruvate carboxykinase (PEPCK, 585 bps), enolase ( 375 bps), histone H3 ( 350 bps), and sodium-potassium ATPase alpha-subunit (NaK, 565 bps). The large ribosomal subunit (16S) was amplified with primers 16S-1471/1472 (Palumbi et al., 1991; Crandall \&

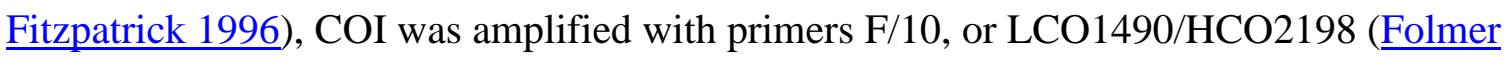
et al., 1994; Bracken-Grissom et al., 2014), 28S was amplified with primers 28S01/28SR-02 (Fiedler et al., 2010), PEPCK with primers -for/-rev (Tsang et al., 2008), enolase with primers EA2/ES2 (Li et al., 2011), H3 with primers AF/AR (Li et al., 2011), and NaK with primers N79/N610 (De Grave et al., 2014). Amplification was performed in $25 \mu 1$ volume reactions containing $12.5 \mu 1$ GoTaq DNA polymerase (Promega, Madison, WI, USA), $1 \mu 1$ forward and reverse primer for each gene, $9.5 \mu 1$ sterile $\mathrm{H} 2 \mathrm{O}$, and $1 \mu 1$ template DNA. The thermal cycling profile conformed to the following parameters: Initial denaturation for $5 \mathrm{~min}$ at $95{ }^{\circ} \mathrm{C}$ followed by 35 cycles of $30 \mathrm{sec}$ at 94 ${ }^{\circ} \mathrm{C}, 45 \mathrm{sec}$ at $48-56{ }^{\circ} \mathrm{C}, 45 \mathrm{sec}$ at $72{ }^{\circ} \mathrm{C}$, and a final extension of $5 \mathrm{~min}$ at $72{ }^{\circ} \mathrm{C}$. PCR products were sent to Genewiz (South Plainfield, NJ, USA) for amplicon purification and subsequent sequencing. 
All sequencing data was visually inspected, quality trimmed, manually cleaned, and assembled using Geneious 9.1.7 (Biomatters, Newark, NJ, USA). Once assembled, sequences were aligned using MAFFT v7.308 (Katoh \& Standley, 2013). To identify potential pseudogenes, we translated protein-coding sequences and checked for insertions and deletions, stop codons, identified the open reading frames, and compared sequences among conspecifics following the protocol of Song et al. (2008).

\section{PHYLOGENETIC ANALYSES}

A dataset consisting of partial sequences of the $16 \mathrm{~S}, 28 \mathrm{~S}$, COI, enolase, $\mathrm{H} 3, \mathrm{NaK}$, and PEPCK gene regions ( $\underline{\text { Table 1) }}$ was constructed to investigate generic and species level relationships across Barbouriidae. Missing data were designated as a "?" in our alignment. We constructed individual gene trees to compare topologies for both datasets. To improve resolution, multiple genes were concatenated into single alignments (Ahyong \& O’Meally, 2004; Porter et al., 2005; Robles et al., 2007; Page et al., 2008). We conducted a partition test of heterogeneity and incongruence length difference test to determine if the gene regions were appropriate to combine for analyses, as implemented in PartitionFinder 2.7.1 and PAUP*, respectively (Swofford, 2002; Lanfear et al., 2016). The model of evolution that best fit the individual data sets was determined by Partitionfinder 2.7.1 (Felsenstein \& Churchill, 1996). Independent models of evolution and parameters were partitioned in the Bayesian concatenated analysis.

The maximum likelihood (ML) analyses were conducted using RAxML (randomized accelerated maximum likelihood; Stamatakis et al., 2005) with computations performed on the high-performance computing cluster at Florida 
International University. Likelihood settings followed the general time reversible model with a gamma distribution and estimates of the proportion of invariable sites (GTR+I+G) and RAxML estimated all free parameters. Confidence in the resulting topologies was assessed using rapid bootstrapping and a search for the best scoring tree with 1,000 replicates (Felsenstein, 1985). We performed Bayesian inference (BI) analyses using parameters selected byPartitionFinder 2.7.1 and conducted in MrBayes v3.2.6 (Huelsenbeck \& Ronquist, 2001). A MCMC algorithm ran for 10,000,000 generations, sampling one tree every 1,000 generations. Observation of likelihood scores allowed us to determine burnins and stationary distributions. Once split frequency in the Bayesian analysis reached $<0.01$, a $50 \%$ majority-rule consensus tree was obtained from the remaining trees. Posterior probabilities for clades were compared for congruence between analyses, bootstrap values $>70$ for RAxML and $>0.90$ for Bayesian are presented on the phylograms.

\section{GENETIC DIVERSITY AND DISTANCE}

We separately calculated nucleotide diversity $(\pi)$ and Tajima's $\mathrm{D}(D)$ for each mitochondrial gene region in PopART v1.7 (Leigh \& Bryant, 2015) to investigate genetic diversity and demographic history across the western Atlantic. To investigate genetic divergence between presently recognized genera of Barbouriidae, Nei's standard genetic distance $\left(D_{A}\right)$ between partial $16 \mathrm{~S}$ sequences were calculated using the Dnadist package of PHYLIP v3.695 (Felsenstein, 1989; Tuimala, 2004). All calculations were conducted following standard parameters. 


\section{RESULTS}

\section{UPDATED PHYLOGENY OF BARBOURIIDAE}

This combined analysis represents 39 terminals from the family Barbouriidae, representing all presently recognized genera, and seven outgroups, Ligur ensiferus (Risso, 1816), Lysmata amboinensis (De Man, 1888), Lysmata debelius Bruce, 1883, Lysmata hochi Baeza \& Anker, 2009, Lysmata intermedia (Kingsley, 1878), Lysmata wurdemanni (Gibbes, 1850), and Latreutes fucorum. New sequences were generated for each gene region (16S, 28S, COI, enolase, H3, NaK, and PEPCK), for three Barbouria cubensis, three B. yanezi, four Calliasmata nohochi, three Janicea antiguensis, one Parhippolyte cavernicola, three $P$. misticia, three $P$. sterreri, five $P$. uveae, and one Latreutes fucorum. Individual gene phylogenies of $16 \mathrm{~S}, 28 \mathrm{~S}$, enolase, $\mathrm{H} 3, \mathrm{NaK}$, and PEPCK are without conflict (Supplementary material Figs. S1-S8). Calliasmata is recovered as sister to Lysmata in the COI phylogeny but has poor support at the conflicting nodes (bootstrap values $<50$ ). All relationships within the concatenated phylogeny were recovered with significant support using ML and Bayesian analyses (Fig. 3). Ligur was the earliest branching lineage and a sister clade to Lysmatidae + Barbouriidae. Calliasmata pholidota and C. nohochi form a monophyletic group (clade 1) and is sister to the remaining barbouriids. Four individuals of B. cubensis and three of B. yanezi form a monophyletic group (clade 2) and is sister to a paraphyletic group of Parhippolyte + Janicea antiguensis. Janicea antiguensis is recovered as a sister species to $P$. sterreri (clade 3), which falls sister to a clade composed of remaining species of Parhipplyte (clades 4 and 5). Clade 4 represents Parhippolyte uveae (including 
P. cf. uveae from GenBank). Parhippolyte cavernicola is recovered as a sister species to P. misticia (clade 5). Several misidentifications or unidentified GenBank individuals were revealed during this study (denoted as * in Figure 3, and these can be found denoted in Table 2).

\section{GENETIC DIVERSITY AND DISTANCE}

Tajima's D and nucleotide diversity $(\pi)$ was calculated based on of the lack of geographic clustering between of B. cubensis and B. yanezi in the phylogeny (clade 2; Fig. 3). The highest values for Tajima's D were negative $\left(D=-2.34721, p_{D}=0.998216\right)$. Genetic diversity was also found to be very low $(\pi=0.998216)$. Mean and standard error values for Nei's $\mathrm{D}\left(D_{A}\right)$ for the $16 \mathrm{~S}$ gene region are reported in Table 3, a heat map with all $16 \mathrm{~S}$ $D_{A}$ values in Table S9. Species within the same genus have a mean genetic distance of $0.010-0.113$ (Table 3). Genera within the same subfamily have genetic distances of $0.113-0.260$. Individuals within the same family have distances of $0.260-0.311$ (Table

3). For individuals within the same superfamily we find genetics distances $>0.311$ (Table 3). We find similar patterns for the genetic distances for the COI partial gene region amplified with the F/10 primers as we find for the $16 \mathrm{~S}$ partial gene region (Table 4). We find individuals of the same species have genetic distances $<0.01$, and individuals within the same genus have genetic distances of $\sim 0.01-0.25$ (Table 4). We find individuals within the same family to have genetic distances of $\sim 0.25-0.32$ (Table 4). For individuals within the same superfamily we find genetic distances of $>0.33$ (Table 4). Oddly, for this locus, we recover Latreutes fucorum to be more closely related to Barbouria and Parhippolyte than Calliasmata nohochi is to Barbouria and Parhippolyte. 


\section{RECLASSIFICATION OF BARBOURIIDAE}

The following classification is proposed for Barbouriidae resulting from molecular evidence generated by this study and the accumulated morphological and molecular evidence in the literature.

Superfamily Alpheoidea Rafinesque, 1815

Family Barbouriidae Christoffersen, 1987

Subfamily Barbouriinae nov. Christoffersen, 1987

Genus Parhippolyte Borradaile, 1900

Parhippolyte antiguensis (Chace, 1972)

Parhippolyte cavernicola Wicksten, 1996

Parhippolyte misticia (Clark, 1989)

Parhippolyte rukuensis Burukovsky, 2007

Parhippolyte sterreri (Hart \& Manning, 1981)

Parhippolyte uveae Borradaile, 1900

Genus Barbouria Rathbun, 1912

Barbouria cubensis (von Martens, 1872)

Subfamily Calliasmatinae nov.

Genus Calliasmata Holthuis, 1973

Calliasmata nohochi Escobar-Briones, Camacho \& Alcocer, 1997

Calliasmata pholidota $\underline{\text { Holthuis, } 1973}$

Calliasmata rimolii $\underline{\text { Chace, } 1975}$ 
SUBFAMILY Calliasmatinae nov.

This is a new subfamily within the family Barbouriidae.

Diagnosis: Sensory dorsal organs of carapace, if present, highly reduced. Infraorbital angle of carapace depressed, inconspicuous below antennal tooth, subocular tooth absent. Rostrum, if present, highly reduced, unarmed. Carapace bearing minute scales or setules. Palp and incisor process of mandible, if present, highly reduced. Eyes highly degenerated, with eyestalks fused basally. First pereiopod and third maxilliped notably robust in comparison to other pereiopods.

Genera included: Calliasmata Holthuis, 1973.

Material examined: see Supplementary material Table S10.

Habitat: Exclusively found in anchialine caves.

Comments: Calliasmatinae represents a new subfamily. Further examination and molecular evidence of $C$. nohochi and $C$. rimolii may reveal that they represent a single species.

SUBFAMILY Barbouriinae nov. Christoffersen, 1987

Diagnosis: Carapace with 2 moderately large and 2 small sensory dorsal organs (Fig. 4); first large organ associated with and posterior to epigastric tooth, second organ medial along dorsal margin located medially within cardiac region, small posterolateral pair juxtaposed to second large organ (Fig. 4). Cornea darkly pigmented, may be broader or narrower than eyestalk. Mandible with 3-jointed palp, incisor process absent. Pereiopods elongated, with or without arthrobranchs at bases of anterior 4 pairs of pereiopods. First 
pereiopods chelate; chelae slender, moderately small. Second pereiopods with carpus divided into articles, ischium and merus faintly subdivided. Third to fifth pereiopods with or without posterior segments subdivided into articles.

Genera included: Parhippolyte Borradaile, 1900 and Barbouria Rathbun, 1912. Material examined: see Supplementary material Table S10.

\section{DISCUSSION}

The classification of Barbouriidae has undergone numerous revisions and still lacks an accurate formal morphological definition (De Grave et al., 2014). Our tree, based on multi-locus phylogenetic methods, includes representatives of all barbouriid genera (Fig. 3). The tree excludes Parhippolyte rukuensis and Calliasmata rimolii as no sequence data is available for these species and attempts to locate molecular-grade material failed. All previous studies have at least one representative of Parhippolyte and found support for the continued recognition of Barbouriidae, with the inclusion of Barbouria, Parhippolyte, and Janicea (Chace, 1997; Fiedler et al., 2010; Baeza, 2013; De Grave et al., 2014; Aznar-Cormano et al., 2015). De Grave et al. (2014) found evidence for the inclusion of Calliasmata into Barbouriidae, based on their phylogenetic analysis of 16S, enolase and $\mathrm{NaK}$, and because all species of Calliasmata are anchialine cave dwellers. While De Grave et al. (2014) advanced our understanding of hippolytid relationships, many generic- and species-level relationships within Barbouriidae remained unresolved due to limited sampling.

Anchialine species are often endemic and increasingly rare. It is important to examine evolutionary relationships between these species and their allies to improve 
management efforts. Our study presents the most comprehensive treatment to date of barbouriid phylogeny. Our results recover Ligur as the earliest branching lineage and is markedly outside of Lysmata. De Grave et al. (2014) found Ligur to be included within Lysmatidae, but our finding shows Ligur to be a distinct lineage, using Latreutus fucorum as the outgroup taxon. It is possible Ligur may need to be considered outside of Lysmatidae; however, further analyses with the inclusion of additional specimens of $L$. ensiferus, and species of Lysmatidae and Hippolytidae is required to resolve this relationship.

Calliasmata is the earliest branching lineage of Barbouriidae, which is in congruence with previous molecular findings (De Grave et al., 2014). More surprising, the genetic distance separating Calliasmata from the remaining barbouriids is comparable to the family-level distances between Lysmatidae and Barbouriidae, suggesting that Calliasmata represents a separate taxonomic group (Tables 3, 4). From a morphological standpoint, Calliasmata lacks any significant synapomorphy previously identified for Barbouriidae as stated by De Grave et al. (2014). The genus differs from genera of Barbouriidae in having the rostrum formed by a simple spine, degenerate and immovable eyes that may or may not be fused, the scaphocerite not reaching beyond the distal margin of the third antennular peduncle and lacking a 3-jointed palp, and the presence of a single podobranch on the second maxilliped and a single arthrobranchs on the third maxilliped (Holthuis, 1973; Chace, 1975; Escobar-Briones et al., 1997). The relationships formed within the multi-locus phylogenetic tree (Fig. 3), genetic distances and morphological evidence, provide strong support that the sub-families Barbouriinae nov. and Calliasmatinae nov. be erected as a monogeneric subfamilies within 
Barbouriidae. Erecting these subfamilies resolves the disparity between morphological and molecular evidence as to the relationship between Calliasmata and other barbouriids (Fig. 3; Tables 3-5), but Barbouriidae still lacks a complete definition (De Grave et al., 2014).

Another surprising result is the phylogenetic position of Janicea antiguensis, significantly supported within Parhippolyte and as the sister taxon to P. sterreri (clade 3; Fig. 3). In all phylogenetic trees, including single gene phylogenies, J. antiguensis was found nested within the genus Parhippolyte. Janicea antiguensis is similar to Parhippolyte in the subdivision of the three posterior pereiopods and having a cornea that is wider than the eyestalk, and is superficially most similar to P. misticia (Chace, 1972; Clark, 1989). Janicea antiguensis is similar to Barbouria in its gill compliment (Chace, 1972; Manning \& Hart, 1984). Clark (1989) drew attention to the appendix masculina (AM) being longer than the appendix interna (AI) as a diagnostic character for Janicea. In the likely case that barbouriid genera are protandric simultaneous hermaphrodites similar to $P$. misticia, however, the length of the AM versus the AI will change as individuals transition from the male to female phase (Onaga et al., 2012). This character and other similar sexually dimorphic characters are thus not viable characters to delineate among species. Morphologically, Janicea seems to represent an intermediate between Parhippolyte and Barbouria, but our molecular results suggest a clear affinity between species of Parhippolyte and J. antiguensis (clade 3; Fig. 3).

Our phylogeny (Fig. 3) finds Parhippolyte to be paraphyletic. The paraphyly can be resolved by either considering Janicea as a junior synonym of Parhippolyte, or by 
resurrecting the genus Somersiella. In our tree, $P$. sterreri is found to form a group with J. antiguensis (clade 3; Fig. 3) and is sister to a clade composed of P. misticia + P. uveae + P. cavernicola (clades 4 and 5; Fig. 3). It is noteworthy that Parhippolyte sterreri was first described as Somersiella sterreri (Hart \& Manning, 1981) and Somersiella was considered distinct from Parhippolyte due to the lack of a podobranch on the second maxilliped (Manning \& Hart, 1984), and whether or not the telson terminated in a sharp point (Christoffersen, 1987). The examination of material of $P$. sterreri revealed a podobranch on the second maxilliped previously diagnosed as being absent, and that characters that are distinct among genera are likely species-specific (Wicksten, 1996). There is no morphological evidence supporting the resurrection of Somersiella (Wicksten, 1996). The inclusion of more material, including P. cavernicola, has helped resolve the relationships among species of Parhippolyte. Based on a lack of morphological evidence and our multi-locus phylogeny, we find the best solution is to consider Janicea as a junior synonym of Parhippolyte and retain P. sterreri within the genus Parhippolyte.

The relationship between $P$. misticia and $P$. uveae could not be resolved using only the available sequences from GenBank. The inclusion of additional material of $P$. misticia, $P$. cavernicola, and $P$. uveae has revealed the evolutionary relationships within this genus and mistaken or unresolved identification of species within Parhippolyte (Table 2). Updating the GenBank and museum records for the corresponding sequences for these Parhippolyte species resolves the conflicts in the phylogenies created by the inclusion of these sequences (Table 2). 
Our phylogeny finds Barbouria cubensis and Barbouria yanezi form a single species, represented by a polytomy in our tree (Fig. 3). Barbouria yanezi was described as a distinct species within Barbouria based on the length of the rostrum, number and positioning of rostral teeth, length to width ratio of the scaphocerite, length ratios of the articles of the first and second pereiopod, length of the appendix masculina versus the appendix interna, number of terminal spines, and maximum recorded carapace length (Mejía et al., 2008). All of the differences between B. yanezi and B. cubensis fall within the range of PhyV documented in B. cubensis (Ditter et al., 2019). Based on the lack of genetic morphological differences we consider Barbouria yanezi to be a synonym of $B$. cubensis. This reverts Barbouria to a monotypic genus.

Some noteworthy phylogeographic patterns emerge in our barbouriid tree (Figs. 2, 3). Barbouria cubensis (Atlantic species) is the earliest branching lineage of Barbouriinae (clade 2; Fig. 3), sister to a clade comprised of P. sterreri $+J$. antiguensis (clade 3; Fig. 3) and P. misticia + P. cavernicola $+P$. uveae (clades 4 and 5; Fig. 3). This would suggest that Barbouriinae originated in the Atlantic after the invasion of caves. Pacific barbouriids also appear superficially similar to Atlantic counterparts, with similar a morphological appearance between $P$. uveae and B. cubensis, $P$. cavernicola and $P$. sterreri, and P. misticia and J. antiguensis (Figs. 1, 5). Our phylogeny also suggests that Barbouriidae likely originated from shallow-water reef species prior to invading caves, instead of deep-sea species, a hypothesis based on the close relationship of Barbouriidae with Lysmatidae. A cornea that is narrower than the eyestalk is a predominant troglodytic adaptation found in Barbouriinae but only present in B. cubensis. Only B. cubensis and $P$. sterreri have the propodus and carpus of the third to fifth pereiopods not articulated. 
Barbouria cubensis and J. antiguensis lack arthrobranchs on the first and second maxillipeds, whereas all species of Barbouriinae have two arthrobranchs on the first and second maxillipeds. These characters suggest that the ancestor of Barbouriinae likely possessed a greater number of troglodytic adaptations that have been lost over time. It is peculiar, however, that J. antiguensis shares characters with both Atlantic and Pacific species of Barbouriidae. Such distribution suggests that after Barbouria further diverged from its troglodytic ancestor barbouriids before invading the Pacific. It would be of particular interest to investigate the results of an ancestral state reconstruction to gain a better understanding when these invasions and divergences occurred.

Our results are not expected to fully resolve the classification of all barbouriids but represents progress towards unraveling the relationships among these species, which have remained enigmatic to caridean systematists. This study is intended to provide clarity into the evolutionary history of Barbouriidae and provide a framework for future studies.

\section{KEY FOR SUBFAMILIES BARBOURIINAE AND CALLIASMATINAE}

Carapace armed with unique subocular tooth posterodorsal to the orbital angle; mandible with 3-jointed palp; carapace with sensory dorsal organs, the first associated and posterodorsal to the epigastric tooth and the second along the dorsal median margin within cardiac region, with smaller pair posterolateral juxtaposed to second sensory dorsal organ Barbouriinae

Infraorbital angle of the carapace depressed and inconspicuous below small antennal tooth, subocular tooth absent; eye highly reduced with eyestalks fused basally; 
rostrum, if present, unarmed, not reaching past eyestalk; palp and incisor process of mandible, if present, highly reduced; third maxilliped and first pereiopod notably robust; sensory dorsal organs, if present, highly reduced

Calliasmatinae

\section{KEY TO SPECIES OF CALLIASMATA, SUBFAMILY CALLIASMATINAE}

(Modified from Escobar-Briones et al., 1997)

1. Rostrum overreaching eyes, antennal spine overreaching distal margin of eyes, third to fifth pleura of abdominal somites with strong ventral tooth, telson margin bearing 3 spines C. pholidota

Rostrum not overreaching eyes, antennal spine almost reaching distal margin of eyes, third to fifth pleura of abdominal somites without ventral tooth, telson margin ....... without spines 2

2. Carapace and integument with setules, third to fifth pleura posteroventral angle acute produced into tooth, propodus of fourth pereiopod 5 times longer than dactylus .... C. nohochi

Setules of carapace and integument, if present, highly reduced, posteroventral angle of third to fifth pleura acute without tooth, propodus of fourth pereiopod 4 times ....... longer than dactylus C. rimolii 


\section{KEY TO GENERA OF SUBFAMILY BARBOURIINAE}

1. Eyes large, cornea darkly pigmented, broader than eyestalk .................................... 2

Eyes reduced, cornea darkly pigmented, narrower than or subequal to the eyestalk

B. cubensis (Fig. 5B)

2. Carpus and propodus of third to fifth pereiopods multiarticulate 3

Carpus and propodus of third to fifth pereiopods not multiarticulate

P. sterreri (Fig. 5D)

3. Anterior 4 pereiopods with arthrobranchs

Anterior 4 pereiopods without arthrobranchs

P. antiguensis (Fig. 5F)

4. Pleuron of fourth abdominal somite rounded or subacute without terminal point ........ 5

Pleuron of fourth abdominal somite acute or subacute with terminal point, fifth and sixth pleuron produced into tooth, appendix masculina of second male pleopod not reaching as far as distal end of appendix interna, terminal margin of telson formed into point, terminating in a strong tooth P. uveae (Fig. 5A)

5. Pleuron 5 of abdominal somite unarmed, appendix masculina of second male pleopod shorter than appendix interna P. cavernicola (Fig. 5C)

Pleuron 5 of abdominal somite produced into tooth, appendix masculina of second male pleopod longer than appendix interna 6

6. Rostrum armed with more than 1 dorsal and ventral teeth, extending almost to the distal end of basal segment of antennular peduncle, terminal margin of telson formed into point, terminating in a weak tooth P. misticia (Fig. 5E)

Rostrum armed with a single dorsal and ventral tooth, not reaching to the distal end of the basal segment of the antennular peduncle

P. rukuensis 


\section{ACKNOWLEDGEMENTS}

We would like to thank Drs. Thomas Iliffe, T.-Y. Chan, Darryl Felder, Craig Layman, Jocelyn Curtis-Quick, and the Cape Eleuthera Institute, The Bahamas for their assistance in the collection of material. We also thank the curators at USNM and MNHN for providing valuable additional material of Parhippolyte. We are grateful for the support and assistance of the Gerace Research Centre, San Salvador, Bahamas and the Bahamian citizens during field work. We are grateful to A. Kerstitch, J. Starmer, T. Iliffe and Meerwasser-Aquaristik-Studio-Korallenkiste, Rosbach vor der Höhe, Germany for providing permission to use photos of barbouriids. We would also like to thank the Dr. Sammy De Grave and the anonymous reviewers for their incite and feedback. This study was supported in part by a student research award from the Gerace Research Centre and The Crustacean Society's Graduate Student Fellowship awarded to RED. LMMO thanks the Consejo Nacional de Ciencia y Tecnología (CONACYT), Mexico to support the exploration in karstic areas in Mexico by funding the project CONACYT-258494 (Fondo Sectorial de Investigación para la Educación). Additional support was provided by Florida International University. This is contribution no. 192 from the Coastlines and Oceans Division of the Institute of Environment at Florida International University.

\section{REFERENCES}

Ahyong, S. \& O’Meally, D. 2004. Phylogeny of the Decapoda Reptantia: Resolution using three molecular loci and morphology. Raffles Bulletin of Zoology, 52: 673693. 
Aznar-Cormano, L., Brisset, J., Chan, T.Y., Corbari, L., Puillandre, N., Utge, J., Zbinden, M., Zuccon, D. \& Samadi, S. 2015. An improved taxonomic sampling is a necessary but not sufficient condition for resolving inter-families relationships in Caridean decapods. Genetica, 143: 195-205.

Baeza, J.A. 2010 Molecular systematics of peppermint and cleaner shrimps: phylogeny and taxonomy of the genera Lysmata and Exhippolysmata (Crustacea: Caridea: Hippolytidae). Zoological Journal of the Linnean Society, 160: 254-265.

Baeza, J.A. 2013. Molecular phylogeny of broken-back shrimps (genus Lysmata and allies): A test of the 'Tomlinson-Ghiselin' hypothesis explaining the evolution of hermaphroditism. Molecular Phylogenetics and Evolution, 69: 46-62.

Baeza, J.A. \& Anker, A. 2009. Lysmata hochi n. sp., a new hermaphroditic shrimp from the southeastern Caribbean Sea (Caridea: Hippolytidae). Journal of Crustacean Biology, 28: 148-155.

Becking, L.E., Renema, W., Santodomingo, N.K., Hoeksema, B.W., Tuti, Y. \& de Voogd, N.J. 2011. Recently discovered landlocked basins in Indonesia reveal high habitat diversity in anchialine systems. Hydrobiologia, 677: 89-105.

Bishop, R.E., Humphreys, W.F., Cukrov, N., Žic, V., Boxshall, G.A., Cukrov, M., Iliffe, T.M., Kršinić, F., Moore, W.S., Pohlman, J.W. \& Sket, B. 2015. 'Anchialine' redefined as a subterranean estuary in a crevicular or cavernous geological setting. Journal of Crustacean Biology, 35: 511-514.

Borradaile, L.A. 1900. On the Stomatopoda and Macrura brought by Dr. Willey from the South Seas. In: Willey, A., Zoological results based on material from New Britain, New Guinea, Loyalty Islands and elsewhere, collected during the years 1895, 1896, and 1897 ..., pp. 395-428. University Press, Cambridge, UK.

Bracken-Grissom, H.D., Ahyong, S.T., Wilkinson, R.D., Feldmann, R.M., Schweitzer, C.E., Breinholt, J.W., Bendall, M., Palero, F., Chan, T.-Y., Felder, D.L., Robles, R., Chu, K.-H., Tsang, L.-M., Kim, D., Martin, J.W. \& Crandall, K.A. 2014. The emergence of the lobsters: phylogenetic relationships, morphological evolution and divergence time comparisons of an ancient group (Decapoda: Achelata, Glypheidea, Polychelida). Systematic Biology, 63: 457-479.

Bracken, H.D., De Grave, S. \& Felder, D.L. 2009a. Phylogeny of the infraorder Caridea based on mitochondrial and nuclear genes (Crustacea: Decapoda). In: Decapod crustacean phylogenetics (J.W. Martin, K.A. Crandall \& D.L. Felder, eds.). Crustacean Issues, 18: 274-300. 
Bracken, H.D., Toon, A, Felder, D.L., Martin, J.W., Finley, M., Rasmussen, J., Palero, F. \& Crandall, K. 2009b. The decapod tree of life: compiling the data and moving toward a consensus of decapod evolution. Arthropod Systematics and Phylogeny, 67: 99-116.

Bruce, A.J. 1883. Lysmata debelius new species, a new hippolytid shrimp from the Philippines. Revue française d'Aquariologie, 9[1982]: 115-120.

Buden, D.W. \& Felder, D.L. 1977. Cave shrimps in the Caicos Islands. Proceedings of the Biological Society of Washington, 90: 108-115.

Burukovsky, R.N. 2007. On some new and rare shrimps from the Indo-Western Pacific. Zoologicheskii Zhurnal, 86: 1-8 [in Russian].

Chace, F.A. 1997. The Caridean shrimps (Crustacea: Decapoda) of the Albatross Philippine Expedition, 1907-1910, part 7: families Atyidae, Eugonatonotidae, Rhynchocinetidae, Bathypalaemonellidae, Processidae, and Hippolytidae. Smithsonian Contributions to Zoology, 587: 1-106.

Chace, F.A. Jr. 1975. Cave shrimps (Decapoda: Caridea) from the Dominican Republic. Proceedings of the Biological Society of Washington, 88: 29-44.

Chace, F.A. 1972. The shrimps of the Smithsonian-Bredin Caribbean Expeditions with a summary of the West Indian shallow-water species (Crustacea: Decapoda: Natantia). Smithsonian Contributions to Zoology, 98: 1-179.

Christoffersen, M.L. 1987. Phylogenetic relationships of hippolytid genera, with an assignment of new families for the Crangonoidea and Alpheoidea (Crustacea, Decapoda, Caridea). Cladistics, 3: 348-362.

Christoffersen, M.L. 1990. A new superfamily classification of the Caridea (Crustacea: Pleocymata) based on phylogenetic pattern. Zeitschrift für Zoologische Systematik und Evoluationsforschung, 28: 94-106.

Clark, J. 1989. Koror misticius, new genus, new species (Decapoda: Hippolytidae), a cave shrimp from Palau. Journal of Crustacean Biology, 9: 445-452.

Crandall, K.A. \& Fitzpatrick, J.F. 1996. Crayfish molecular systematics: Using a combination of procedures to estimate phylogeny. Systematic Biology, 45: 1-26.

De Grave, S., Li, C.P., Tsang, L.M., Chu, K.H. \& Chan, T.Y. 2014. Unweaving hippolytoid systematics (Crustacea, Decapoda, Hippolytidae): Resurrection of several families. Zoologica Scripta, 43: 496-507. 
De Man, J.G. 1888. Bericht über die von Herrn Dr. J. Brock im indischen Archipel gesammelten Decapoden und Stomatopoden. Archiv für Naturgeschichte, 53: 289-600, pls. 11-22a.

Ditter, R.E., Erdman, R.B., Goebel, A.M. \& Bracken-Grissom, H.D. 2019. Widespread phenotypic hypervariation in the enigmatic anchialine shrimp Barbouria cubensis (Decapoda: Barbouriidae). Zootaxa [doi: 10.11646/Zootaxa.5648.1.1].

Escobar-Briones, E., Camacho, M.E. \& Alcocer, J. 1997. Calliasmata nohochi, new species (Decapoda: Caridea: Hippolytidae), from Anchialine Cave systems in continental Quintana Roo, Mexico. Journal of Crustacean Biology, 17: 733-744.

Fabricius, J.C. 1798. Supplementum Entomologiae Systematicae. Proft \& Storch, Hafniae [= Copenhagen].

Felsenstein, J. 1985. Confidence limits of phylogenies: an approach using the bootstrap. Evolution, 39: 783-791.

Felsenstein, J. 1989. PHYLIP - Phylogeny Inference Package (Version 3.2). Cladistics, 5: 164-166.

Felsenstein, J. \& Churchill, G.A. 1996. A hidden Markov model approach to variation among sites in rate of evolution. Molecular Biology and Evolution, 13: 93-104.

Fiedler, G.C., Rhyne, A.L., Segawa, R., Aotsuka, T. \& Schizas, N.V. 2010. The evolution of euhermaphroditism in caridean shrimps: a molecular perspective of sexual systems and systematics. BMC Evolutionary Biology, 10: 297 [doi: 10.1186/14712148-10-297].

Folmer, O., Black, M., Hoeh, W., Lutz, R. \& Vrijenhoek, R. 1994. DNA primers for amplification of mitochondrial cytochrome c oxidase subunit I from diverse metazoan invertebrates. Molecular Marine Biology and Biotechnology, 3: 294299.

Fransen, C.H.J.M. \& Tomascik, T. 1996. Parhippolyte uveae Borradaile, 1899 (Crustacea: Decapoda: Hippolytidae) from Kakaban Island, Indonesia. Zoologische Mededelingen, 70: 227-233.

Gibbes, L.R. 1850. Catalogue of the Crustacea in the Cabinet of the Academy of Natural Sciences of Philadelphia. Proceedings of the Academy of Natural Sciences of Philadelphia, 5: 22-30.

Hart, C.W. \& Manning, R.B. 1981. The cavernicolous caridean shrimps of Bermuda (Alpheidae, Hippolytidae, and Atyidae). Journal of Crustacean Biology, 1: 441456. 
Hobbs, H.H. Jr., Hobbs, H.H. III \& Daniel, M.A. 1977. A review of the troglobitic decapod crustaceans of the Americas. Smithsonian Contributions to Zoology, 244: $1-177$.

Holthuis, L. 1973. Caridean shrimps found in land-locked saltwater pools at four IndoWest Pacific localities (Sinai Peninsula, Funafuti Atoll, Maui and Hawaii Islands): with the description of one new genus and four new species. Zoologische Verhandelingen, 128: 3-48.

Huelsenbeck, J.P. \& Ronquist, F. 2001. MrBayes: Bayesian inference of phylogenetic trees. Bioinformatics, 17: 745-755.

Iliffe, T.M. \& Kornicker, L.S. 2009. Worldwide diving discoveries of living fossil animals from the depths of anchialine and marine caves. Smithsonian Contributions to Marine Sciences, 38: 269-280.

Iliffe, T.M. 1996. Somersiella sterreri. The IUCN Red List of Threatened Species 1996 e.T20371A9192483 [doi: 10.2305/IUCN.UK.1996.RLTS. T20371A9192483.en].

Katoh, K. \& Standley, D.M. 2013. MAFFT Multiple Sequence Alignment Software Version 7: Improvements in performance and usability. Molecular Biology and Evolution, 30: 772-780.

Kemp, S. 1914. Hippolytidae. Notes on Crustacea Decapoda in the Indian Museum, V. Records of the Indian Museum, 10: 81-129.

Kingsley, J.S. 1878. Notes on the North American Caridea in the Museum of the Peabody Academy of Science at Salem, Mass. Proceedings of the Academy of Natural Sciences of Philadelphia, 1878: 89-98.

Lanfear, R., Frandsen, P.B., Wright, A.M., Sendfeld, T. \& Calcott, B. 2016. PartitionFinder 2: New methods for selecting partitioned models of evolution for molecular and morphological phylogenetic analyses. Molecular Biology and Evolution, 34: 772-773.

Leigh, J.W. \& Bryant, D. 2015. PopART: Full-feature software for haplotype network construction. Methods in Ecology and Evolution, 6: 1110-1116.

Legall, N. \& Poupin, J. 2018. CRUSTA: Database of Crustacea (Decapoda and Stomatopoda), with special interest for those collected in French overseas territories [http://crustiesfroverseas.free.fr/].

Li, C.P., De Grave, S., Chan, T.-Y., Lei, H.C. \& Chu, K.H. 2011. Molecular systematics of caridean shrimps based on five nuclear genes: Implications for superfamily classification. Zoologischer Anzeiger, 250: 270-279. 
Manning, R.B. \& Hart, C.W. 1984. The status of the hippolytid shrimp genera Barbouria and Ligur (Crustacea: Decapoda): A Reevaluation. Proceedings of the Biological Society of Washington, 97: 655-665.

Martens, E., von. Über cubanische Crustaceen nach den Sammlungen Dr. J. Gundlach's. Archiv für Naturgeschichte, 38: 77-147.

Mejía, L.M., Zarza, E. \& López, M. 2008. Barbouria yanezi sp. nov., a new species of cave shrimp (Decapoda, Barbouriidae) from Cozumel Island, Mexico. Crustaceana, 81: 663-672.

Onaga, H., Fiedler, G. \& Baeza, J. 2012. Protandric simultaneous hermaphroditism in Parhippolyte misticia (Clark, 1989) (Caridea: Hippolytidae): implications for the evolution of mixed sexual systems in. Journal of Crustacean Biology, 32: 383394.

Palumbi, S., Martin, A., Romano, S., McMillan, W.O., Stice, L. \& Grabowski, G. 1991. The simple fool's guide to PCR. Department of Zoology and Kewalo Marine Laboratory, University of Hawaii, Honolulu.

Page, T.J., Short, J.W., Humphrey, C.L., Hillyer, M.J. \& Hughes, J.M. 2008. Molecular systematics of the Kakaducarididae (Crustacea: Decapoda: Caridea). Molecular Phylogenetics and Evolution, 46: 1003-1014.

Pérez-Moreno, J.L., Iliffe, T.M. \& Bracken-Grissom, H.D. 2016. Life in the underworld: anchialine cave biology in the era of speleogenomics. International Journal of Speleology, 45: 149-170.

Porter, M.L., Perez-Losada, M. \& Crandall, K.A. 2005. Model-based multi-locus estimation of decapod phylogeny and divergence times. Molecular Phylogenetics and Evolution, 37: 355-369.

Rafinesque, C.S. 1815. Analyse de la nature ou Tableau de l'univers et des corps organisés. Palermo, Italy [English translation by A.J. Cain, 1990, Tryonia, 20: 104-218].

Rathbun, M.J. 1912. Some Cuban Crustacea, with notes on the Astacidae by Walter Faxon, and a list of Isopoda, by Harriet Richardson. Bulletin of the Museum of Comparative Zoology, 54 (15): 451-460, pls. 1-5.

Risso, A. 1816. Histoire naturelle des Crustacés des environs de Nice. Librairie GrecqueLatine-Allemande, Paris. 
Robles, R., Schubart, C.D., Conde, J.E., Carmona-Suarez, C., Alvarez, F., Villalobos, J.L. \& Felder, D.L. 2007. Molecular phylogeny of the American Callinectes Stimpson, 1860 (Brachyura: Portunidae), based on two partial mitochondrial genes. Marine Biology, 150: 1265-1274.

Sarato, C. 1885. Ligur Edwardsii, Nob. Études sur les Crustacés de Nice. In: Le Moniteur des Étrangers à Nice, 9 (222): 2.

Song, H., Buhay, J.E., Whiting, M.F. \& Crandall, K.A. 2008. Many species in one: DNA barcoding overestimates the number of species when nuclear mitochondrial pseudogenes are coamplified. Proceedings of the National Academy of Sciences of the United States of America, 105: 13486-13491.

Stamatakis, A., Ludwig, T. \& Meier, H. 2005. RAxML-III: a fast program for maximum likelihood-based inference of large phylogenetic trees. Bioinformatics, 21: 456463.

Swofford, D.L. 2002. PAUP*: phylogenetic analysis using parsimony (* and other methods). Sinauer, Sunderland, MA, USA.

Tsang, L.M., Ma, K.Y., Ahyong, S.T., Chan, T.-Y. \& Chu, K.H. 2008. Phylogeny of Decapoda using two nuclear protein-coding genes: origin and evolution of the Reptantia. Molecular Phylogenetics and Evolution, 48: 359-368.

Tuimala, J. 2004. A primer to phylogenetic analysis using Phylip Package, Edn. 2. Center for Scientific Computing, Espoo, Finland.

Wicksten, M.K. 1996. Parhippolye cavernicola, new species (Decapoda: Caridea: Hippolytidae) from the Tropical Eastern Pacific, with taxonomic remarks on the genera Somersiella and Koror. Journal of Crustacean Biology, 16: 201-207. 


\section{TABLES}

Table 1. Species used in phylogenetic reconstruction for the family Barbouriidae [see Material and Methods for the museum abbreviations]. Accession numbers for partial sequences of COI we generated using the LCO1490/HCO2198 and F/10 primers respectively. Individuals with successful amplification for both regions will have two accession numbers for the COI gene.

\section{Reproduced with permission from Oxford University Press.}

\begin{tabular}{|c|c|c|c|c|c|c|c|c|c|c|}
\hline \multirow{2}{*}{ Taxon } & \multirow[b]{2}{*}{ Collection locatlity } & \multirow{2}{*}{ Museum catalog no. } & \multicolumn{8}{|c|}{ GenBank accession no. } \\
\hline & & & $16 \mathrm{~S}$ & $28 \mathrm{~S}$ & Enolas & H3 & $\mathrm{NaK}$ & PEPCK & & \\
\hline Barbouria cubensis & San Salvador, Bahamas & HBG1937 & MT505235 & MT505191 & MT527421 & MT527448 & MT527503 & MT527477 & MT524340 & MT540990 \\
\hline B. cubensis & San Salvador, Bahamas & HBG2151 & MT505236 & MT505192 & MT527422 & MT527449 & MT527504 & MT527478 & MT524341 & MT540991 \\
\hline B. cubensis & San Salvador, Bahamas & HBG2198 & MT505237 & MT505193 & MT527423 & MT527450 & MT527505 & MT527479 & MT524342 & MT540992 \\
\hline B. cubensis & San Salvador, Bahamas & OUMNH.ZC.2010-05-003 & KF023098 & - & KF023142 & - & KF023173 & - & - & \\
\hline B. yanezi & Cozumel, Mexico & HBG9168 & MT505238 & - & - & MT527451 & - & - & - & MT540993 \\
\hline B. yanezi & Cozumel, Mexico & HBG9180 & MT505239 & MT505194 & MT527424 & MT527452 & MT527506 & MT527480 & - & MT540994 \\
\hline B. yanezi & Cozumel, Mexico & HBG9181 & MT505240 & MT505195 & - & MT527453 & - & MT527481 & - & MT540995 \\
\hline Calliasmata pholidota & Hawaii, USA & OUMNH.ZC.2010-04-003 & KF023119 & - & KF023151 & - & KF023182 & - & - & - \\
\hline C. nohochi & Mexico & A. Baeza, pers. coll. & - & - & KF178861 & KF178838 & - & - & - & - \\
\hline C. nohochi & Mayaguana, Bahamas & HBG10007 & MT505231 & MT505187 & MT527417 & MT527444 & MT527499 & MT527473 & MT524336 & MT549845 \\
\hline C. nohochi & Mayaguana, Bahamas & HBG10008 & MT505232 & MT505188 & MT527418 & MT527445 & MT527500 & MT527474 & MT524337 & MT549846 \\
\hline C. nohochi & Mayaguana, Bahamas & HBG10009 & MT505233 & MT505189 & MT527419 & MT527446 & MT527501 & MT527475 & MT524338 & MT549847 \\
\hline C. nohochi & Mayaguana, Bahamas & HBG10010 & MT505234 & MT505190 & MT527420 & MT527447 & MT527502 & MT527476 & MT524339 & MT549848 \\
\hline Janicea antiguensis & Cape Verde, Africa & OUMNH.ZC.2004-15-002 & MT505241 & MT505196 & MT527425 & MT527454 & MT527507 & MT527482 & MT524343 & - \\
\hline J. antiguensis & Giant Cave, Belize & HBG9999 & MT505242 & MT505197 & MT527426 & MT527455 & MT527508 & MT527483 & - & MT542150 \\
\hline J. antiguensis & Giant Cave, Belize & HBG10000 & MT505243 & MT505198 & MT527427 & MT527456 & MT527509 & MT527484 & MT524344 & MT542151 \\
\hline Parhippolyte cavernicola & Baja California Sur, Mexico & HBG10136/USNM-273315 & MT505253 & MT505208 & MT527431 & MT527470 & MT527524 & - & MT534287 & - \\
\hline P. misticia & Odo Point, Okinawa, Japan & Fiedler et al., 2010 & HQ315615 & HQ315560 & - & - & - & - & - & - \\
\hline P. misticia & Shagakko-mae, Japan & HBG10126/NTOU-M01157-E & - & MT505204 & - & MT527465 & MT527518 & MT527491 & MT524349 & MT542196 \\
\hline P. misticia & Shagakko-mae, Japan & HBG10127/NTOU-M01157-F & - & MT505205 & MT527436 & MT527466 & MT527519 & MT527492 & MT524350 & MT542197 \\
\hline P. misticia & Shagakko-mae, Japan & HBG10128/NTOU-M01157-G & - & MT505206 & MT527437 & MT527467 & MT527520 & MT527493 & - & MT542198 \\
\hline P. sterreri & San Salvador, Bahamas & HBG1941 & MT505244 & MT505199 & MT527428 & MT527457 & MT527510 & MT527485 & MT524345 & MT542201 \\
\hline 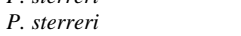 & San Salvador, Bahamas & HBG1943 & MT505245 & MT505200 & MT527429 & MT527458 & MT527511 & MT527486 & MT524346 & MT542200 \\
\hline P. sterreri & San Salvador, Bahamas & HBG2149 & MT505246 & MT505201 & MT527430 & MT527459 & MT527512 & MT527487 & MT524347 & MT542199 \\
\hline P. sterreri & Iguana Cay, Exumas, Bahamas & MNHN-IU-2012-1057 & KP725619 & KP726001 & - & KP726178 & - & - & KP759480 & - \\
\hline Parahyppolyte sp. & Japan NTOU & M01675/TWH-2014 & KF023096 & - & KF023140 & - & KF023171 & - & - & - \\
\hline P.cf. uveae & Okinawa, Japan & JAB-2013 & KF178886 & - & KF178877 & KF178855 & - & - & - & - \\
\hline P. uveae & Society Islands, French Polynesia & HBG10114/MNHN-IU-2012-1001 & MT505247 & MT505202 & MT527432 & MT527460 & MT527513 & MT527488 & - & MT542192 \\
\hline P. uveae & Society Islands, French Polynesia & HBG10115/MNHN-IU-2012-1002 & MT505248 & MT505203 & MT527433 & MT527461 & MT527514 & MT527489 & - & MT542193 \\
\hline P. uveae & Coral Sea & HBG10117/MNHN-IU-2018-3568-B & MT505249 & - & MT527434 & MT527462 & MT527515 & MT527490 & - & MT542194 \\
\hline P. uveae & Aldabra, Seychelles & HBG10130/ USNM-280216-85(1) & MT505251 & - & MT527438 & MT527468 & MT527521 & MT527494 & MT524351 & - \\
\hline P. uveae & Aldabra, Seychelles & HBG10134/USNM-280216-85(2) & - & - & - & MT527469 & MT527522 & MT527495 & MT524352 & MT542202 \\
\hline P. uveae & Aldabra, Seychelles & HBG10135/USNM-280216-86(3) & MT505252 & MT505207 & MT527432 & MT527460 & MT527513 & MT527488 & MT524353 & MT542203 \\
\hline Lysmata amboinensis & Not ava & HBG395/KC9045 & MT505229 & MT527439 & - & - & MT527472 & - & MT542204 & \\
\hline L. debelius & Not Available & MLP121 & DQ079718 & DQ079793 & - & DQ079681 & - & - & - & - \\
\hline L. hochi & Long Key, FL, USA & UMML32.9460 & EU861507 & - & KF178810 & KF178848 & - & - & КС962174 & - \\
\hline L. intermedia & Bocas Del Toro, Panama & UMML32.9461 & EU861484 & - & KF178871 & KF178849 & KF023169 & - & КС962203 & - \\
\hline L. wurdemanni & Gulf of Mexico & HBG546/KC4529/ULLZ17433 & MT505230 & MT505186 & MT527440 & MT527443 & MT527498 & - & - & _- \\
\hline Ligur ensiferus & Guadeloupe & MNHN-IU-2012-1000 & KP725542 & KP725926 & KF023141 & KP726104 & KF023172 & - & - & - \\
\hline Latreutes fucorum & Gulf of Mexico & HBG2764 & MT505228 & MT505184 & MT527441 & MT527442 & MT527497 & MT527471 & - & MT563442 \\
\hline
\end{tabular}


Table 2. Original and corrected identifications of taxa in Barbouriidae. See Material and Methods for museum abbreviations.

Reproduced with permission of Oxford University Press.

\begin{tabular}{cll}
\hline Museum catalog no. & \multicolumn{1}{c}{ Original } & Corrected \\
\cline { 2 - 3 } HBG9168 & Barbouria yanezi & Barbouria cubensis \\
HBG9180 & Barbouria yanezi & Barbouria cubensis \\
HBG9181 & Barbouria yanezi & Barbouria cubensis \\
HBG66/OUMNH.ZC.2004-15-002 & Janicea antiguensis & Parhippolyte antiguensis \\
HBG9999 & Janicea antiguensis & Parhippolyte antiguensis \\
HBG10000 & Janicea antiguensis & Parhippolyte antiguensis \\
HBG10115/MNHN-IU-2012-1002 & Parhippolyte uveae & Parhippolyte misticia \\
HBG10117/MNHN-20018-3568 & Parhippolyte uveae & Parhippolyte misticia \\
NTOU M01675/TWH-2014 & Parhippolyte uveae & Parhippolyte misticia \\
JAB-2013 & Parhippolyte sp. & Parhippolyte misticia \\
\hline
\end{tabular}


Table 3. Mean (and standard error) of genetic distances between genera of Barbouriidae for the 16S partial gene regions.

Reproduced with permission of Oxford University Press.

\begin{tabular}{lcccccc}
\hline & Ligur & Lysmata & Calliasmata & Barbouria & Janicea & Parhippolyte \\
\hline Ligur & $0.022(0.025)$ & $0.309(0.024)$ & $0.321(0.006)$ & $0.329(0.000)$ & $0.344(0.010)$ & $0.304(0.027)$ \\
Lysmata & $0.309(0.024)$ & $0.112(0.104)$ & $0.329(0.015)$ & $0.334(0.021)$ & $0.352(0.018)$ & $0.330(0.029)$ \\
Calliasmata & $0.331(0.005)$ & $0.344(0.015)$ & $0.099(0.118)$ & $0.311(0.006)$ & $0.303(0.022)$ & $0.300(0.021)$ \\
Barbouria & $0.329(0.000)$ & $0.334(0.021)$ & $0.311(0.006)$ & $0.000(0.000)$ & $0.260(0.007)$ & $0.238(0.014)$ \\
Janicea & $0.344(0.010)$ & $0.352(0.018)$ & $0.303(0.022)$ & $0.260(0.007)$ & $0.007(0.009)$ & $0.113(0.018)$ \\
Parhippolyte & $0.304(0.027)$ & $0.330(0.029)$ & $0.300(0.021)$ & $0.238(0.014)$ & $0.113(0.018)$ & $0.089(0.054)$ \\
\hline
\end{tabular}


Table 4. Genetic distances for the $\mathrm{CO} 1$ partial gene region in species of Barbouriidae amplified with the F/10 primers. GenBank accession numbers and alternative museum catalog numbers are listed in Table 1. Individuals with asterisk $(*)$ represent misidentified species in GenBank. See Table 2 for the correct identifications. Reproduced with permission of Oxford University Press.

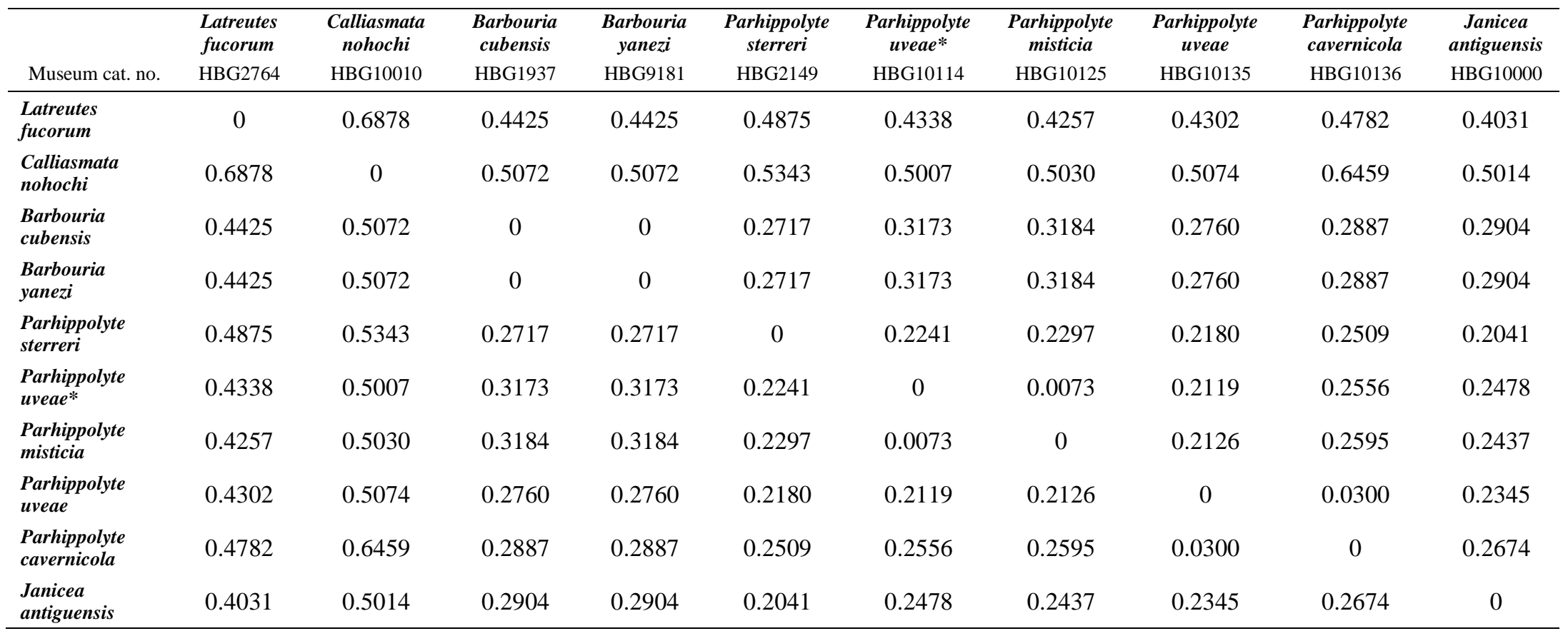


Table 5. Comparison between diagnostic characters of Barbouriinae and Calliasmatinae. Reproduced with permission of Oxford University Press.

\begin{tabular}{lll}
\hline Barbouriinae nov. & Calliasmatinae nov. \\
\hline $1 \quad \begin{array}{l}\text { Rostrum with dorsal and ventral margin armed, usually reaching } \\
\text { beyond the eyestalk. }\end{array}$ & $\begin{array}{l}\text { Rostrum, if present, highly reduced and unarmed, } \\
\text { not reaching beyond eyestalk. }\end{array}$ \\
2 & Carapace with subocular tooth. & Carapace without subocular tooth. \\
3 & Carapace smooth, without setules. & Carapace and integument bearing setules. \\
4 & $\begin{array}{l}\text { Sensory dorsal organs of carapace well developed; associated with } \\
\text { epigastric tooth and within cardiac region (Fig. 4). }\end{array}$ & $\begin{array}{l}\text { Sensory dorsal organs of carapace, if present, } \\
\text { highly reduced. }\end{array}$ \\
5 & $\begin{array}{l}\text { Mandible with 3-jointed palp. } \\
\text { Palp of mandible, if present, much reduced. }\end{array}$ & $\begin{array}{l}\text { Cornea darkly pigmented and well developed. } \\
\text { Cornea, if present, highly degenerated. }\end{array}$ \\
7 & $\begin{array}{l}\text { Eyestalk not fused basally. } \\
\text { Third maxilliped and first pereiopod narrow and elongated, slightly }\end{array}$ & $\begin{array}{l}\text { Third maxilliped and first pereiopod notably more } \\
\text { robust versus remaining pereiopods. }\end{array}$ \\
\hline
\end{tabular}




\section{FIGURE CAPTIONS}

Figure 1. Examples of Barbouriidae taxa. Parhippolyte uveae (Photo by Meerwasser-Aquaristik-Studio-Korallenkiste) (A). Barbouria cubensis (Photo by R.E. Ditter) (B). Parhippolyte cavernicola (Photo by A. Kerstitch) (C). Parhippolyte sterreri (Photo by R.E. Ditter) (D). Parhippolyte misticia (Photo by J. Starmer in Legall \& Poupin, 2018) (E). Janicea antiguensis (Photo by T. Iliffe) (F). Reproduced with permission of Oxford University Press.

Figure 2. Distribution of the genera Barbouria, Calliasmata, Janicea and Parhippolyte. P. rukuensis excluded because it was described from a single female collected from YehHim Island, Ryukyu Archipelago, Japan. Reproduced with permission of Oxford University Press.

Figure 3. Bayesian (BI) phylogram for Barbouriidae $(N=8)$ based on a $16 \mathrm{~S}, 28 \mathrm{~S}, \mathrm{COI}$, Enolase, $\mathrm{H} 3, \mathrm{NaK}$ and PEPCKconcatenated data set. BI posterior probabilities and Maximum Likelihood (ML) bootstrap values noted above branches. Values $>0.7$ for ML and $>90 \%$ for BI are shown and represented by percentages. Vertical black bars represent the native range for each species. Catalog numbers represent voucher specimens housed in the Florida International Crustacean Collection (FICC). * Indicates a clade likely comprised of a single species. ** Indicates chimeric individuals. Reproduced with permission of Oxford University Press. 
Figure 4. Sensory Dorsal Organ (SDO) of Barbouriidae on Barbouria cubensis

(Illustrated by R.E. Ditter). SDO associated with and posterior to the epigastric tooth (A).

Single large SDO within cardiac region and a small pair juxtaposed to the larger SDO

(B). Scale bar $=1 \mathrm{~mm}$. Reproduced with permission of Oxford University Press.

Figure 5. Illustrated examples of Barbouriidae taxa. Parhippolyte uveae (from Fransen \& Tomascik, 1996, fig. 1) (A). Barbouria cubensis (from Hobbs, Hobbs \& Daniel 1977, fig.

33) (B). Parhippolyte cavernicola (from Wicksten, 1996, fig. 1) (C). Parhippolyte

sterreri formerly Somersiella sterreri (from Hart \& Manning, 1981, fig. 1) (D).

Parhippolyte misticia (from Clark, 1989, fig. 1) (E). Janicea antiguensis (from Chace, 1972, fig. 40b) (F). Reproduced with permission of Oxford University Press. 
FIGURES

Figure 1.

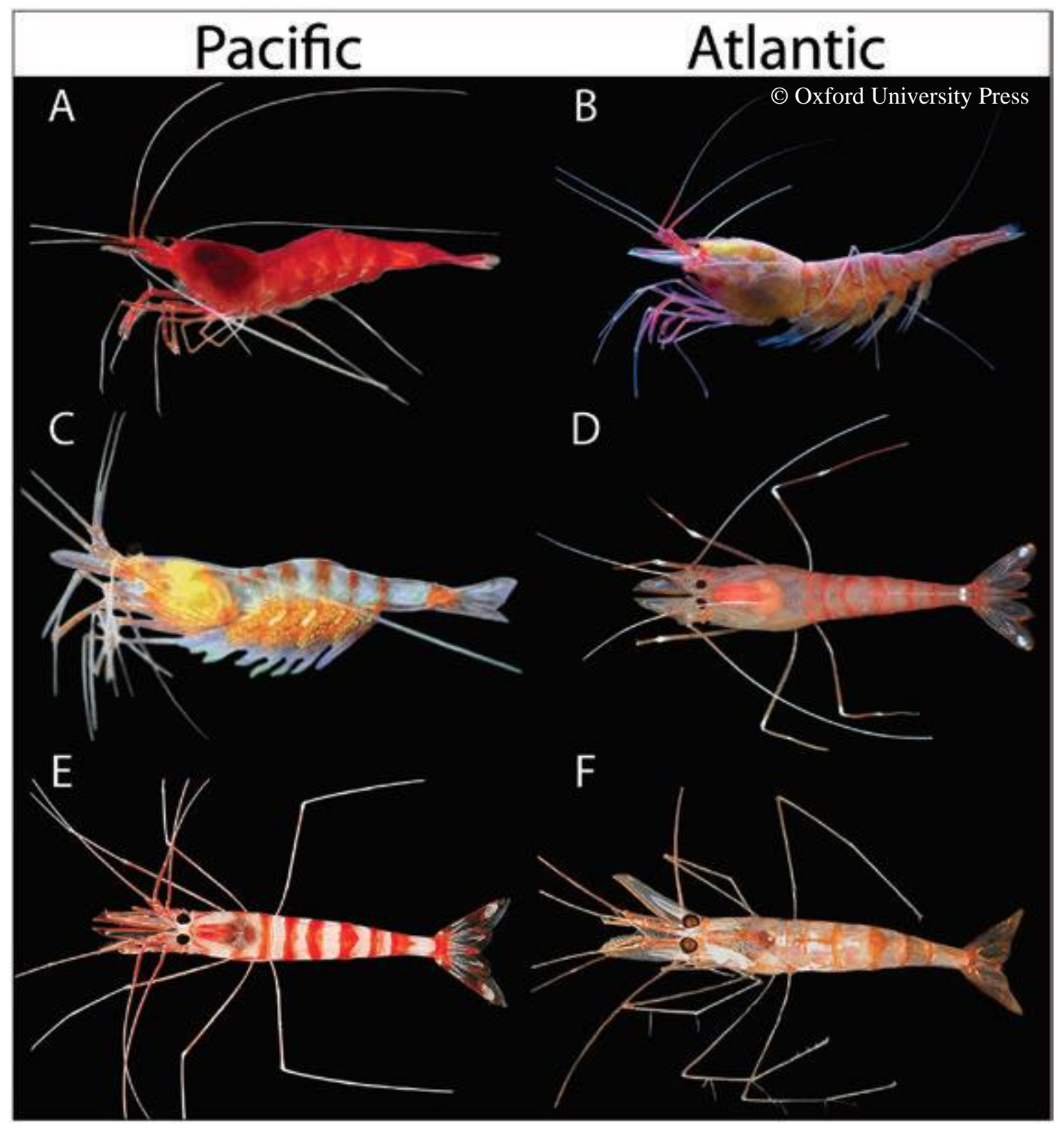


Figure 2.

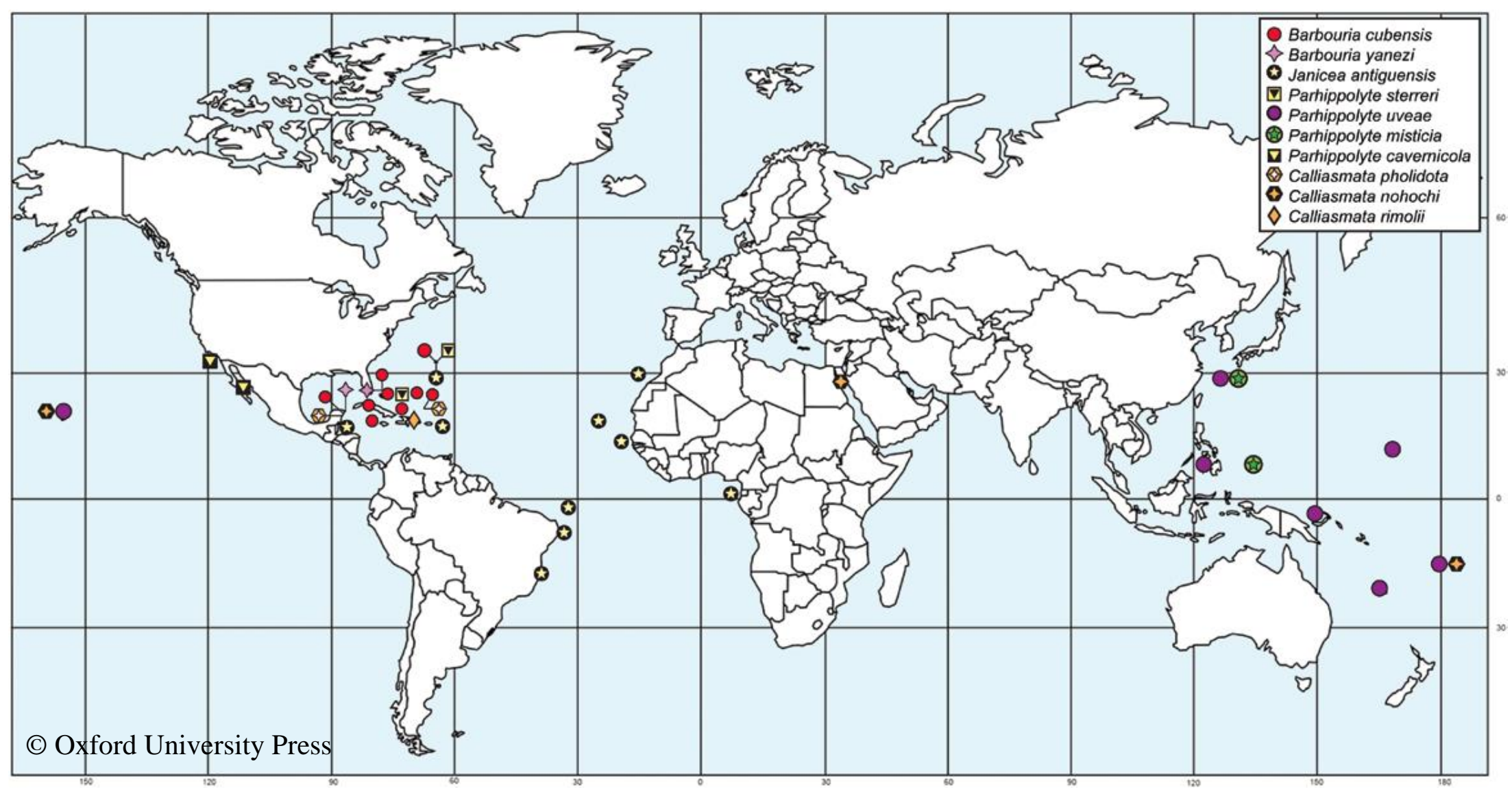


Figure 3.

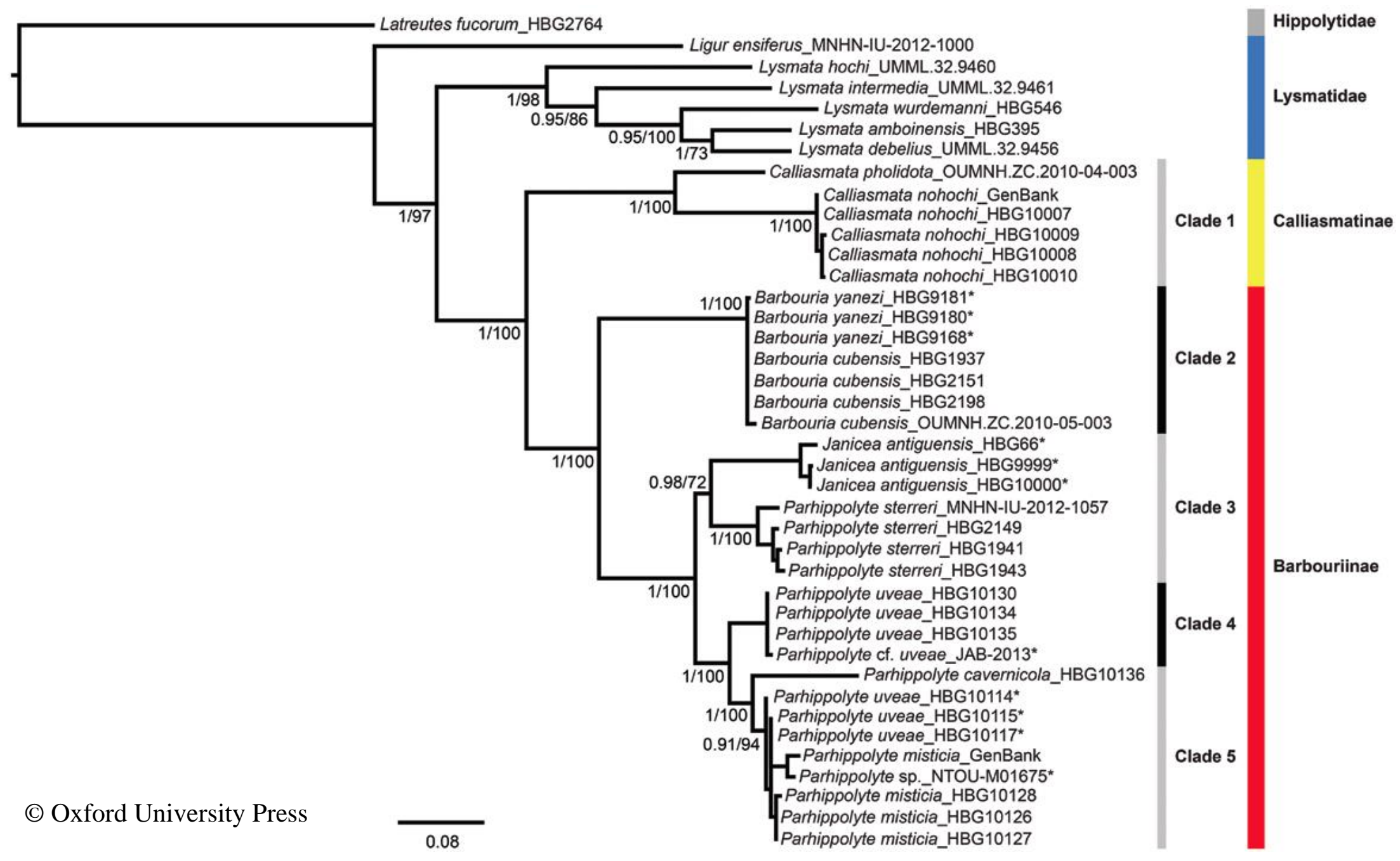


Figure 4.

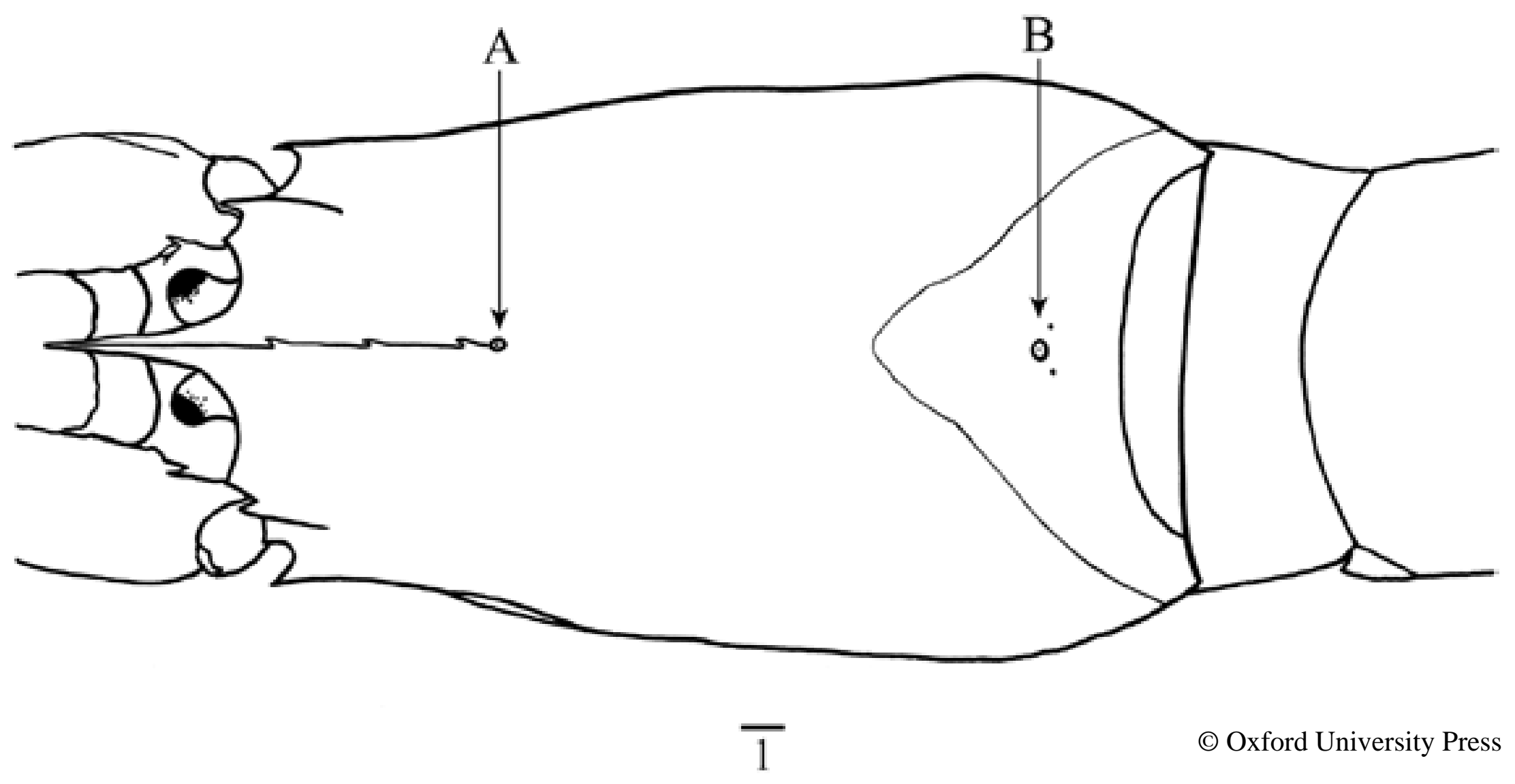


Figure 5.

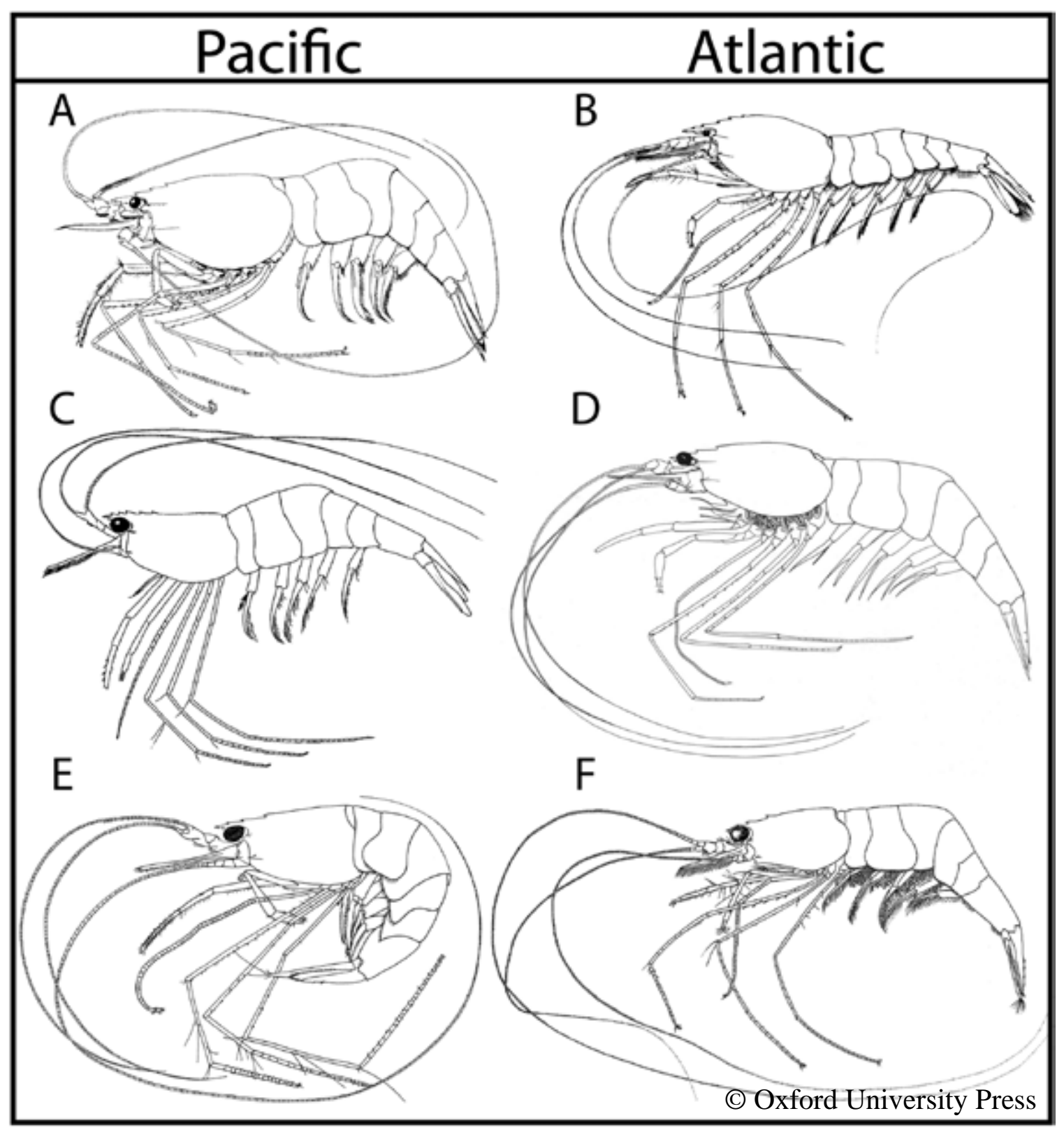




\section{SUPPLEMENTARY MATERIAL (CAPTIONS)}

Supplementary material is available at Journal of Crustacean Biology online.

S1 Figure. 16S loci phylogeny with support values calculated using RAxML.

Reproduced with permission of Oxford University Press.

S2 Figure. 28S loci phylogeny with support values calculated using RAxML.

Reproduced with permission of Oxford University Press.

S3 Figure. Enolase loci phylogeny with support values calculated using RAxML.

Reproduced with permission of Oxford University Press.

S4 Figure. H3 loci phylogeny with support values calculated using RAxML. Reproduced with permission of Oxford University Press.

S5 Figure. NaK loci phylogeny with support values calculated using RAxML. Reproduced with permission of Oxford University Press.

S6 Figure. PEPCK loci phylogeny with support values calculated using RAxML. Reproduced with permission of Oxford University Press.

S7 Figure. COI loci (amplified with F/10 primers) phylogeny with support values calculated using RAxML. Reproduced with permission of Oxford University Press. S8 Figure. COI loci (amplified with LCO1490/HCO2198 primers) phylogeny with support values calculated using RAxML. Reproduced with permission of Oxford University Press.

S9 Table. Heat map and genetic distances (DA) for the $16 \mathrm{~S}$ partial gene region. Reproduced with permission of Oxford University Press.

S10 Table. Material of Barbouriidae examined. Reproduced with permission of Oxford University Press. 
Figure S1.

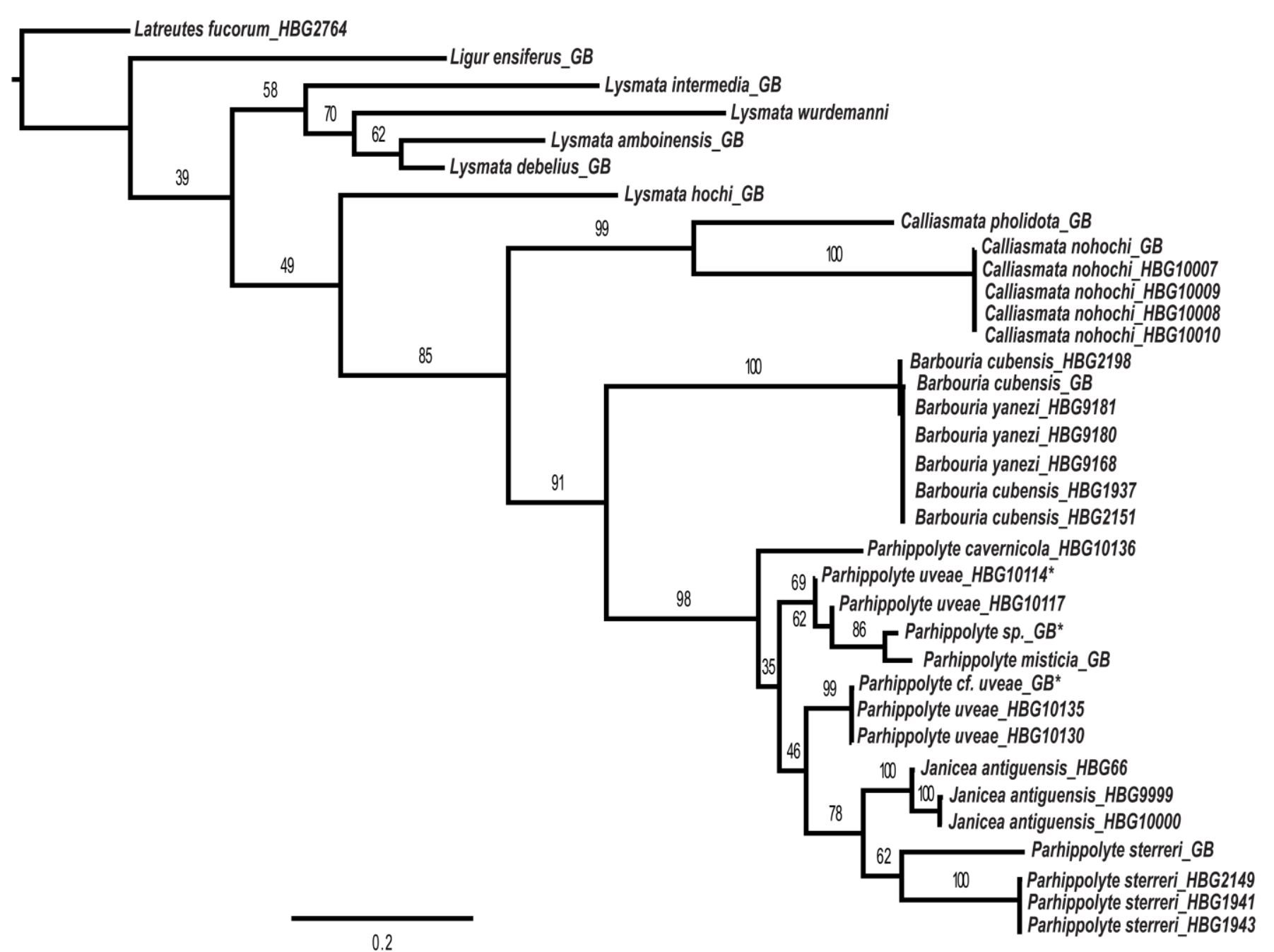

(C) Oxford University Press 
Figure S2.

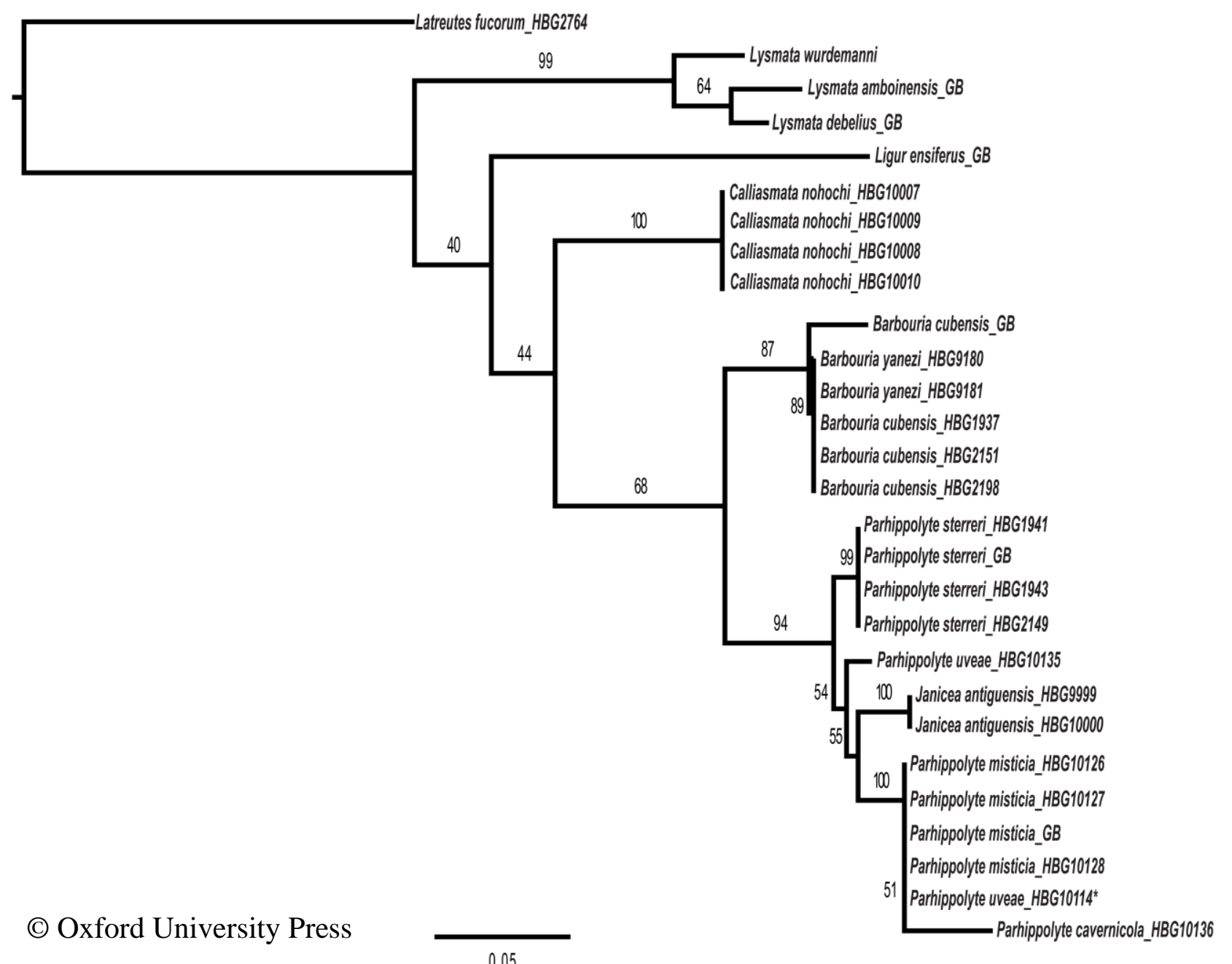


Figure S3.

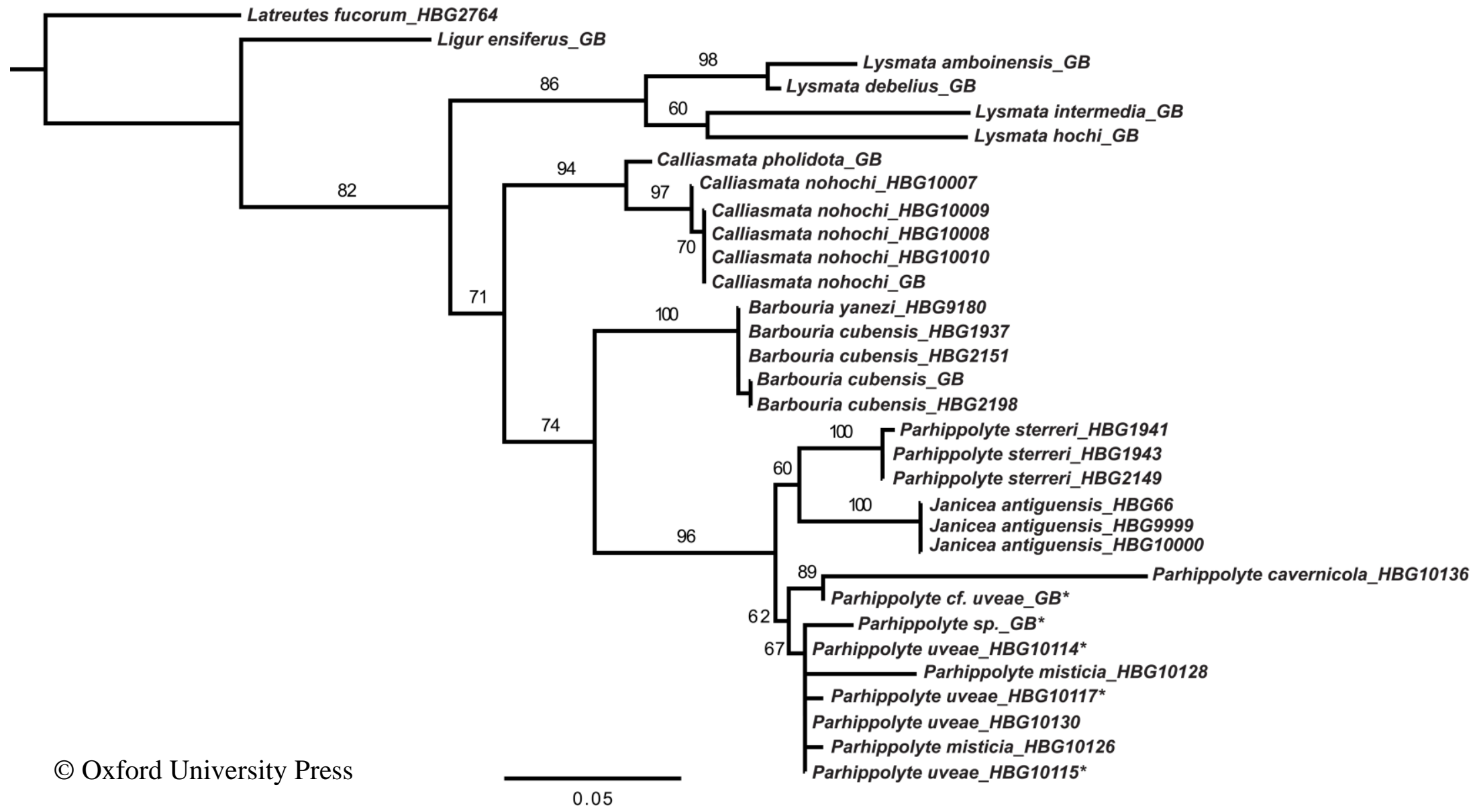


Figure S4.

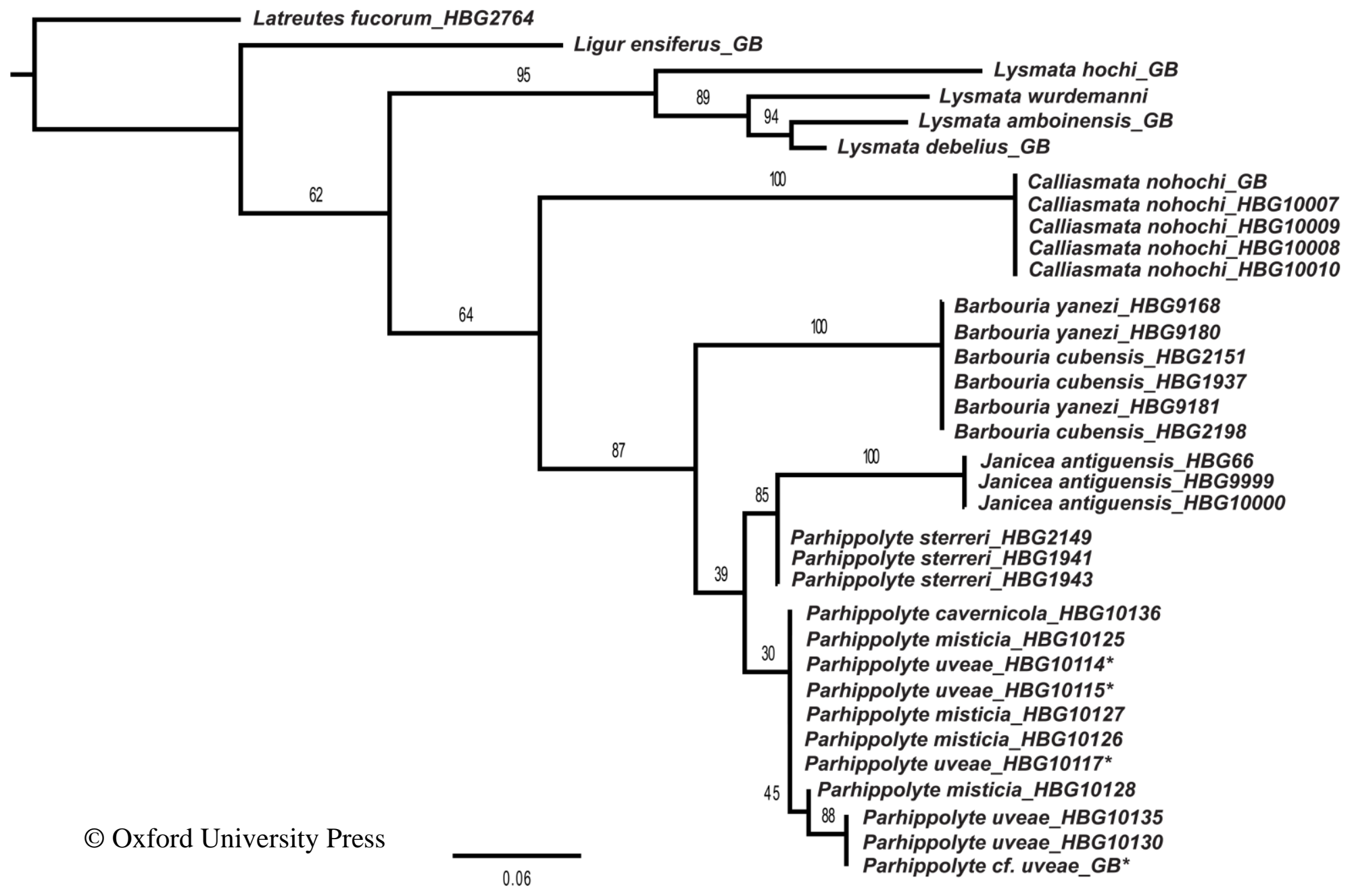


Figure S5.

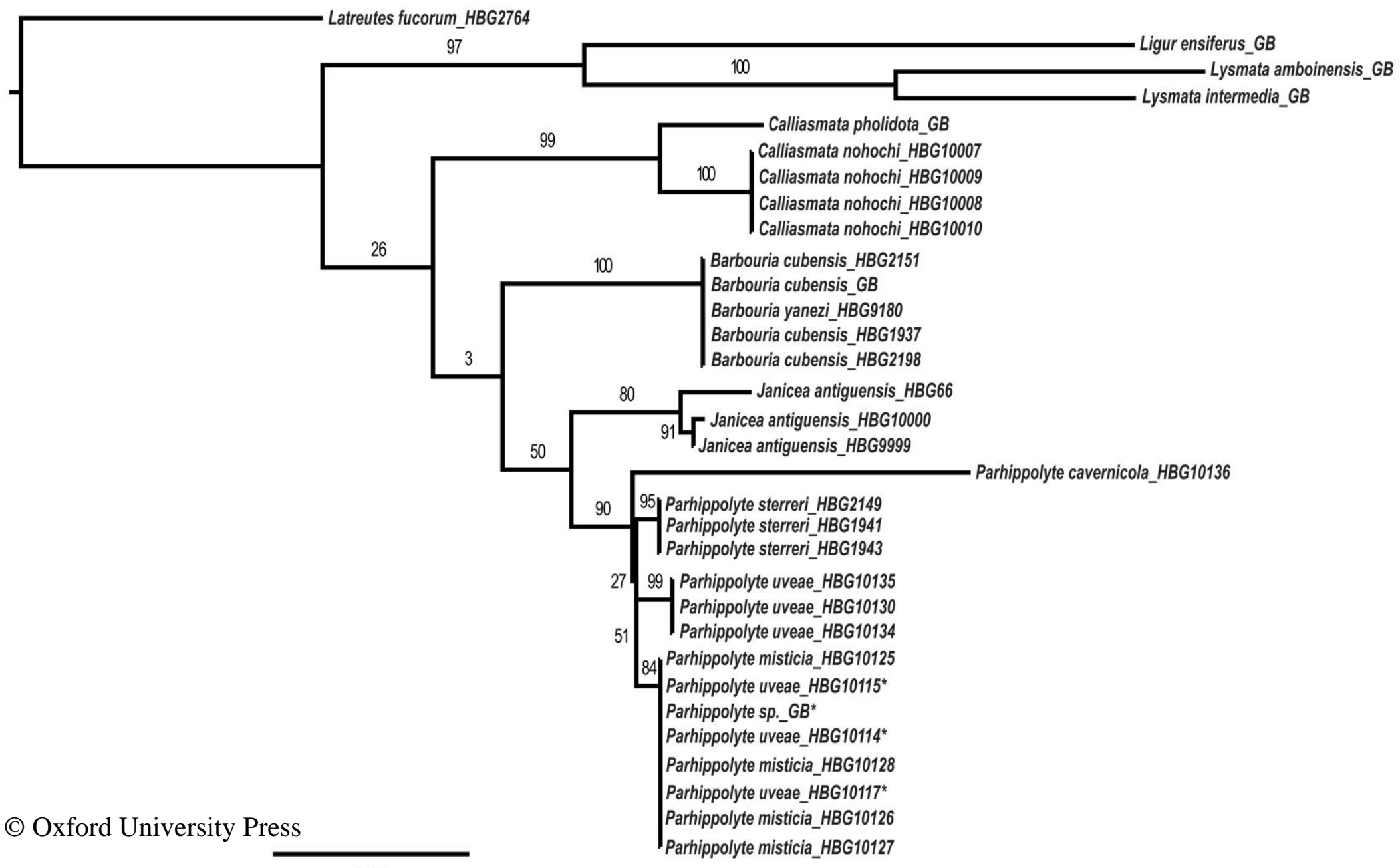


Figure S6.

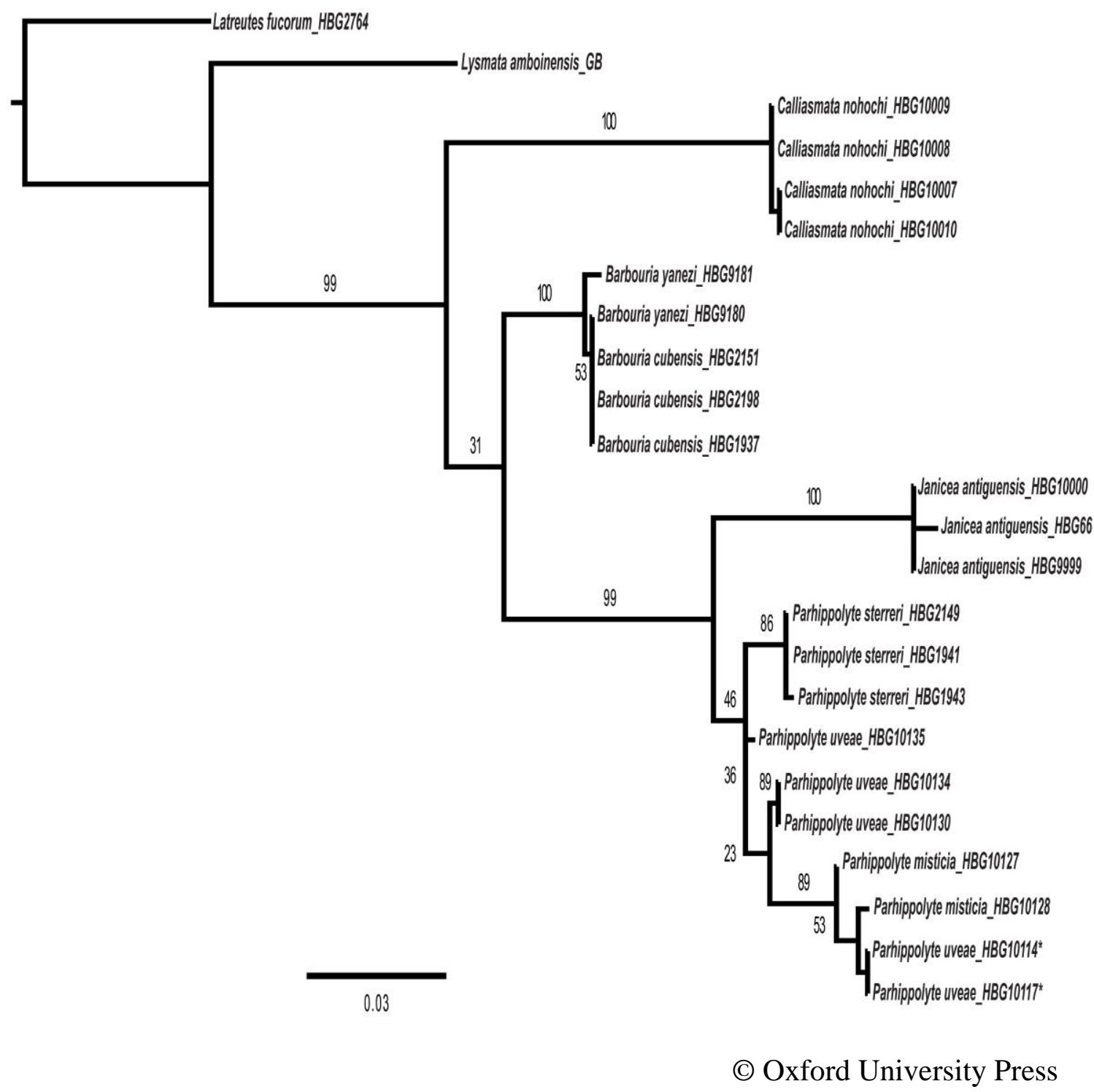


Figure S7.

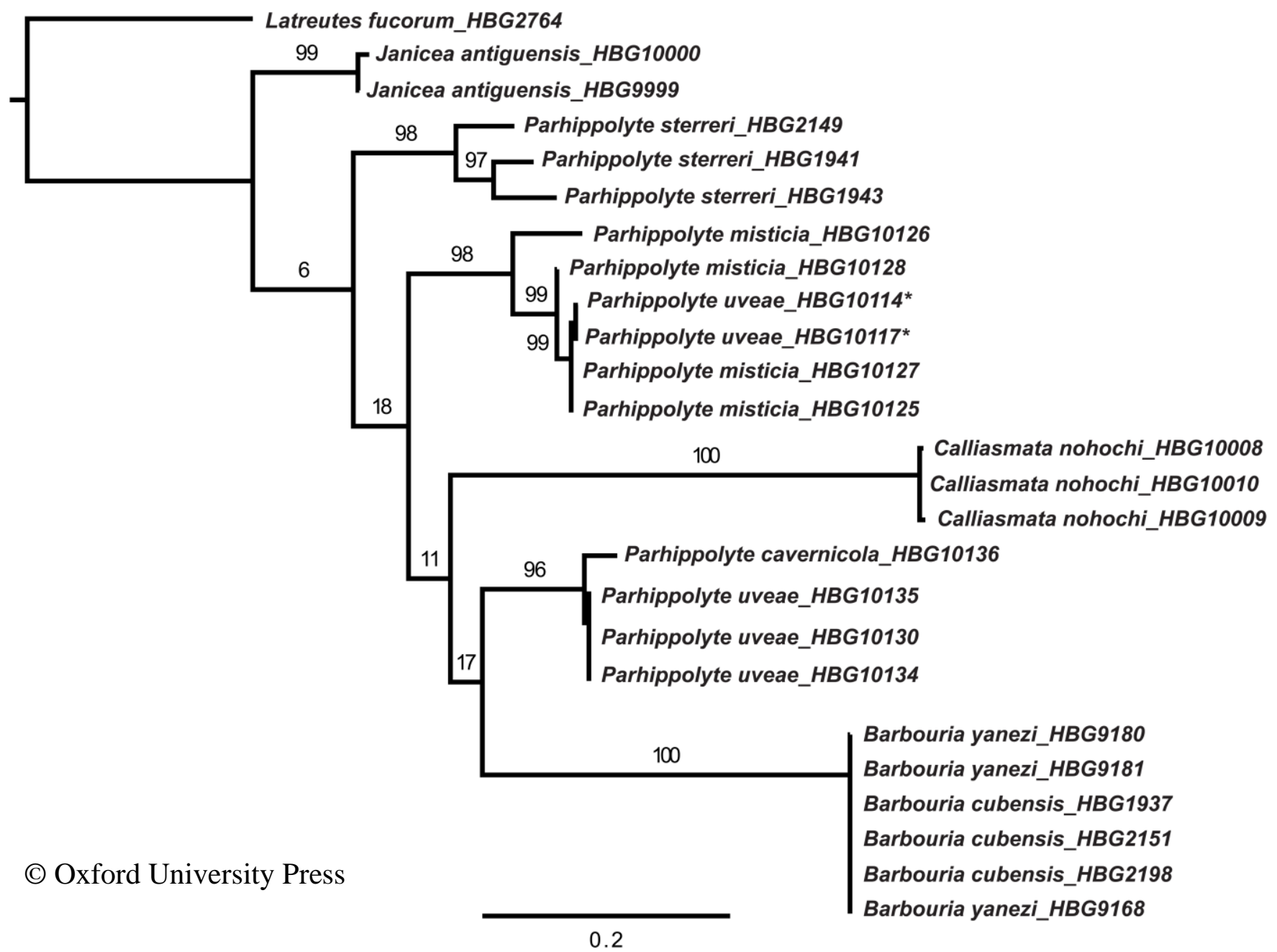




\section{Figure S8.}

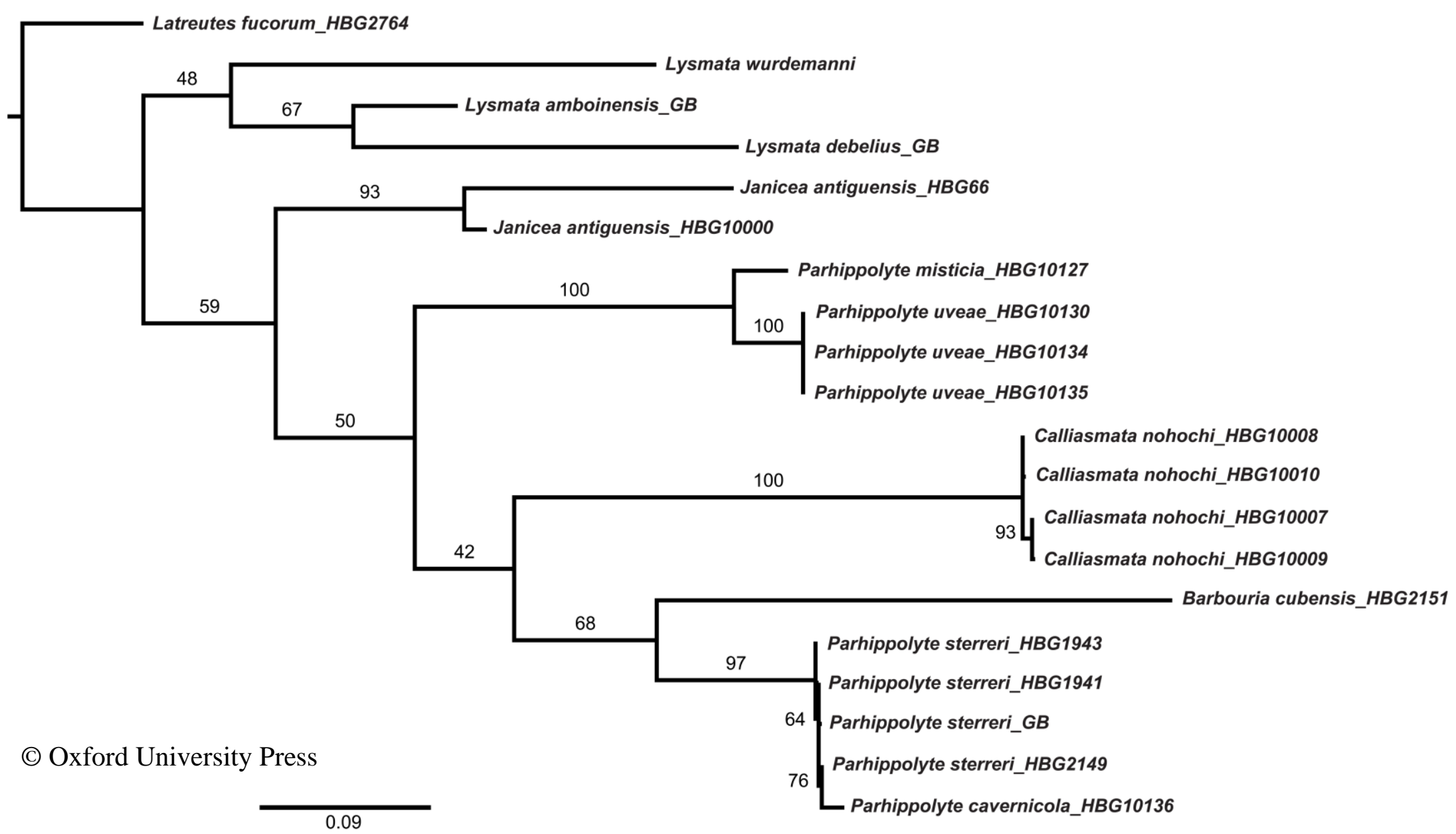


Table S9.

\begin{tabular}{|c|c|c|c|c|c|c|c|c|c|c|c|c|c|c|c|c|c|c|}
\hline & \multirow[b]{2}{*}{ Accession\# } & \multicolumn{2}{|c|}{ Barbouria yanezi } & \multicolumn{3}{|c|}{ Janicea antiguensis } & \multicolumn{3}{|c|}{ Parhippolyte sterreri } & \multicolumn{2}{|c|}{ Parhippolyte uveae } & \multirow{2}{*}{$\begin{array}{c}\text { Parhippolyte } \\
\text { cf. uveae* } \\
\text { KF178886 } \\
\end{array}$} & \multirow{2}{*}{$\begin{array}{c}\text { Parhippolyte } \\
\text { misticiat } \\
\text { HBG10114 }\end{array}$} & \multicolumn{3}{|c|}{ Parhippolyte misticia } & \multirow{2}{*}{$\begin{array}{r}\text { Parhippolyte } \\
\text { sp.* } \\
\text { KF023096 } \\
\end{array}$} & \multirow{2}{*}{$\begin{array}{l}\text { Parhippolytete } \\
\text { cavernicola } \\
\text { HBG10136 }\end{array}$} \\
\hline & & HBG9180 & HBG9181 & HBG9999 & HBG10000 & HBG66 & HBG1941 & HBG1943 & HBG2149 & HBG10130 & HBG10135 & & & HBG10115 & HBG10117 & HQ315615 & & \\
\hline \multirow{2}{*}{$\begin{array}{l}\text { Latreutes } \\
\text { fucorum }\end{array}$} & HBG2764 & 0.365824 & 0.365824 & 0.415082 & 0.415082 & 0.406113 & 0.389588 & 0.385521 & 0.385521 & 0.423012 & 0.414966 & 0.411927 & 0.397846 & 0.38596 & 0.393763 & 0.394733 & 0.388535 & 0.410047 \\
\hline & KP725541 & 0.332399 & 0.332399 & 0.358349 & 0.358155 & 0.334909 & 0.317445 & 0.316608 & 0.316608 & 0.313373 & 0.313373 & 0.313373 & 0.317145 & 0.306951 & 0.310718 & 0.308855 & 0.305622 & 0.238938 \\
\hline \multirow[t]{2}{*}{ Ligur ensiferus } & KF023097 & 0.332399 & 0.332399 & 0.358349 & 0.358155 & 0.334909 & 0.317445 & 0.316608 & 0.316608 & 0.313373 & 0.313373 & 0.313373 & 0.317145 & 0.306951 & 0.310718 & 0.308855 & 0.305622 & 0.238938 \\
\hline & KP725542 & 0.327993 & 0.327993 & 0.361689 & 0.358456 & 0.337797 & 0.305497 & 0.304704 & 0.304704 & 0.313156 & 0.313156 & 0.313156 & 0.320181 & 0.310042 & 0.313738 & 0.308801 & 0.308728 & 0.239931 \\
\hline \multirow{6}{*}{$\begin{array}{l}\text { Lysmata } \\
\text { debelius } \\
\text { Lysmata } \\
\text { intermedia } \\
\text { Lysmata } \\
\text { amboinensis } \\
\text { Lysmata } \\
\text { wurdemanni } \\
\text { Lysmata hochi } \\
\text { Calliasmata } \\
\text { pholidota }\end{array}$} & DQ079718 & 0.331156 & 0.331156 & 0.343521 & 0.343521 & 0.326453 & 0.330152 & 0.329315 & 0.329315 & 0.341839 & 0.329377 & 0.329377 & 0.313571 & 0.286012 & 0.309195 & 0.317019 & 0.298723 & 0.268663 \\
\hline & EU861484 & 0.328078 & 0.328078 & 0.386011 & 0.386011 & 0.374252 & 0.362533 & 0.361599 & 0.361599 & 0.369931 & 0.359669 & 0.356797 & 0.349322 & 0.33861 & 0.356843 & 0.377834 & 0.356507 & 0.284403 \\
\hline & KF023091 & 0.345003 & 0.345003 & 0.374373 & 0.374373 & 0.355774 & 0.356814 & 0.355848 & 0.355848 & 0.350279 & 0.345276 & 0.342299 & 0.328287 & 0.296102 & 0.327823 & 0.337267 & 0.301749 & 0.278659 \\
\hline & HBG546 & 0.3976 & 0.3976 & 0.427344 & 0.430433 & 0.411942 & 0.405539 & 0.404449 & 0.404449 & 0.40648 & 0.39762 & 0.39762 & 0.375339 & 0.378808 & 0.380218 & 0.378586 & 0.361908 & 0.367499 \\
\hline & EU861507 & 0.295098 & 0.295098 & 0.340632 & 0.340632 & 0.329497 & 0.329002 & 0.328159 & 0.328159 & 0.341886 & 0.3321 & 0.329249 & 0.317237 & 0.299363 & 0.310218 & 0.328814 & 0.306692 & 0.254464 \\
\hline & KF023119 & 0.306875 & 0.306875 & 0.286379 & 0.283618 & 0.277285 & 0.2656 & 0.264977 & 0.264977 & 0.269345 & 0.265729 & 0.268661 & 0.272932 & 0.301442 & 0.274814 & 0.303705 & 0.295264 & 0.294686 \\
\hline \multirow{3}{*}{$\begin{array}{l}\text { Calliasmata } \\
\text { nohochi }\end{array}$} & HBG10007 & 0.314351 & 0.314351 & 0.34753 & 0.350585 & 0.328733 & 0.323746 & 0.322957 & 0.322957 & 0.330455 & 0.324862 & 0.328048 & 0.315543 & 0.299374 & 0.318562 & 0.299324 & 0.304212 & 0.280738 \\
\hline & HBG10009 & 0.314351 & 0.314351 & 0.34753 & 0.350585 & 0.328733 & 0.323746 & 0.322957 & 0.322957 & 0.330455 & 0.324862 & 0.328048 & 0.315543 & 0.299374 & 0.318562 & & 0.304212 & 0.280738 \\
\hline & HBG10010 & 0.314351 & 0.314351 & 0.34753 & 0.350585 & 0.328733 & 0.323746 & 0.322957 & 0.322957 & 0.330455 & 0.324862 & 0.328048 & 0.315543 & 0.299374 & 0.318562 & 0.299324 & 0.304212 & 0.280738 \\
\hline \multirow{4}{*}{$\begin{array}{l}\text { Barbouria } \\
\text { cubensis }\end{array}$} & HBG1937 & & 0 & 0.278128 & 0.280927 & 0.266742 & 0.265531 & 0.264913 & 0.264913 & 0.250927 & 0.242562 & & 0.2379 & 0.236037 & & & & 0.225807 \\
\hline & G2151 & 0 & 0 & 0.278128 & 0.280927 & 0.2667 & 0.265531 & 0.264913 & 0. & 0.250927 & & & 020 & & & & & 0.225807 \\
\hline & HBG2198 & 0.001923 & 0.001923 & 0.275406 & 0.278198 & 0.264054 & 0.262804 & 0.262194 & 0.262194 & 0.253729 & 0.245256 & 0.245256 & 0.235208 & 0.238729 & 0.231986 & 0.252026 & 0.238743 & 0.231825 \\
\hline & HBG9168 & 0 & 0 & 0.278128 & 0.280927 & 0.266742 & 0.265531 & 0.264913 & 0.264913 & 0.250927 & 0.242562 & 0.242562 & 0.237913 & 0.236037 & 0.234676 & 0.252026 & 0.241521 & 0.225807 \\
\hline \multirow{3}{*}{$\begin{array}{l}\text { Barbouria } \\
\text { yanezi }\end{array}$} & HBG9180 & 0 & 0 & 0.278128 & 0.280927 & 0.266742 & 0.265531 & 0.264913 & 0.264913 & 0.250927 & 0.242562 & 0.242562 & 0.237913 & 0.236037 & 0.234676 & 0.252026 & & 0.225807 \\
\hline & & 0 & 0 & 0.278128 & 0.280927 & 0.266742 & 0.265531 & 0.264913 & 0.264913 & 0.250927 & 0.242562 & 0.242562 & 0.237913 & 0.236037 & 0.234676 & 0.252026 & 0.241521 & 0.225807 \\
\hline & HBG9999 & 0.278128 & 0.278128 & 0 & 0.003833 & 0.021425 & 0.128802 & 0.128543 & 0.128543 & 0.116051 & & & 118787 & 0.143228 & 0.123344 & 0.165212 & 0.141693 & 0.165967 \\
\hline \multirow{2}{*}{$\begin{array}{l}\text { Janicea } \\
\text { antiguensis }\end{array}$} & HBG10000 & & 0.280927 & 0.003833 & 0 & 0.021425 & 0.128748 & 0.12849 & & 0.116002 & & & & & & & & 0.16068 \\
\hline & HBG66 & 0.266742 & 0.266742 & 0.021425 & 0.021425 & 0 & 0.119649 & 0.119411 & 0.119 & 0.095 & 0.094 & 0.097229 & 74 & 0.120323 & & & 0.12 & 0.118873 \\
\hline \multirow{3}{*}{$\begin{array}{l}\text { Parhippolyte } \\
\text { sterreri }\end{array}$} & & 0.265531 & 0.265531 & 0.128802 & 0.128748 & 0.119649 & 0 & 0.001952 & 0.001952 & & & & & & & & & 0.119993 \\
\hline & HBG1943 & 0.264913 & 0.264913 & 0.128543 & 0.128 & 0.119411 & 0.001952 & 0 & 0 & 0.157 & 0.152 & & 0.13 & 0.15 & 0.13 & 0.16 & 0.14 & 0.124726 \\
\hline & G2149 & 0.264913 & 0.264913 & 0.128543 & & 0.119411 & 0.001952 & 0 & 0 & 0.157537 & 0.152719 & & & & & & & 0.124726 \\
\hline \multirow{4}{*}{$\begin{array}{l}\text { Parhippolyte } \\
\text { uveae } \\
\text { Parhippolyte } \\
\text { cf. uveae* } \\
\text { Parhippolyte }^{*} \\
\text { misticia* }^{*}\end{array}$} & HBG10130 & 0.250927 & 0.250927 & 0.116051 & 0.116002 & 0.095669 & 0.157872 & 0.157537 & 0.157537 & 0 & 0 & 0.00198 & 0.079744 & 0.103226 & 0.093262 & 0.134882 & 0.130844 & 0.093228 \\
\hline & HBG10135 & 0.242562 & 0.242562 & 0.112616 & 0.11257 & 0.094996 & 0.153034 & 0.152719 & 0.152719 & 0 & 0 & 0.001926 & 0.079744 & 0.102435 & 0.093262 & 0.134882 & 0.129317 & 0.093228 \\
\hline & KF178886 & 0.242562 & 0.242562 & 0.114902 & 0.114855 & 0.097229 & 0.150772 & 0.150463 & 0.150463 & 0.00198 & 0.001926 & 0 & 0.081986 & 0.104709 & 0.09555 & 0.137621 & 0.131795 & 0.093228 \\
\hline & HBG10114 & 0.237913 & 0.237913 & 0.118787 & 0.118736 & 0.098274 & 0.134507 & 0.134224 & 0.134224 & 0.079744 & 0.079744 & 0.081986 & 0 & 0.066771 & 0.01201 & 0.070296 & 0.05801 & 0.098945 \\
\hline \multirow{3}{*}{$\begin{array}{l}\text { Parhippolyte } \\
\text { misticia }\end{array}$} & HBG10115 & 0.236037 & 0.236037 & 0.143228 & 0.143168 & 0.120323 & 0.152092 & 0.151777 & 0.151777 & 0.103226 & 0.102435 & 0.104709 & 0.066771 & 0 & 0.053533 & 0.043516 & 0.022626 & 0.088661 \\
\hline & HBG10117 & 0.234676 & $\begin{array}{l}0.234676 \\
\end{array}$ & 0.123344 & & 0.10274 & 0.136819 & & & & & & & & 0 & 0.0554 & & 0.093239 \\
\hline & HQ315615 & 0.252026 & 0.252026 & 0.165212 & 0.159654 & 0.14074 & 0.166888 & 0.166485 & 0.166485 & 0.134882 & 0.134882 & 0.137621 & 0.070296 & 0.043516 & 0.0554 & 0 & 0.036637 & 0.092258 \\
\hline \multirow{2}{*}{$\begin{array}{l}\text { Parhippolyte } \\
\text { sp.* } \\
\text { Parhippolyte } \\
\text { cavernicola }\end{array}$} & KF023096 & 0.241521 & 0.241521 & 0.141693 & 0.14163 & 0.122382 & 0.14106 & 0.140755 & 0.140755 & 0.130844 & 0.129317 & 0.131795 & 0.05801 & 0.022626 & 0.044503 & 0.036637 & 0 & 0.090394 \\
\hline & HBG10136 & 0.225807 & 0.225807 & 0.165967 & 0.16068 & 0.118873 & 0.119993 & 0.124726 & 0.124726 & 0.093228 & 0.093228 & 0.093228 & 0.098945 & 0.088661 & 0.093239 & 0.092258 & 0.090394 & 0 \\
\hline
\end{tabular}


Table S10.

\begin{tabular}{|c|c|c|c|c|c|c|}
\hline \multicolumn{2}{|c|}{ Taxon } & \multirow{2}{*}{$\begin{array}{c}\text { FICC } \\
\text { catalog no. }\end{array}$} & \multirow{2}{*}{$\begin{array}{l}\text { Alt. museum } \\
\text { catalog no. }\end{array}$} & \multirow{2}{*}{ Collection date } & \multirow{2}{*}{ Locality } & \multirow{2}{*}{ No. } \\
\hline original & corrected & & & & & \\
\hline Calliasmata nohochi & & HBG 10006 & TI-07-001 & Jul 2007 & Mayaguana, Bahamas & 8 \\
\hline Barbouria cubensis & & HBG3188 & ULLZ-11739 & Nov 2009 & Abaco, Bahamas & 1 \\
\hline B. cubensis & & HBG3355-5600 & & Mar 2015-Mar 2016 & Abaco, Bahamas & 42 \\
\hline B. cubensis & & $\begin{array}{l}\text { HBG3390, } \\
\text { HBG8028-8151 }\end{array}$ & & Jul 2017 & Acklins Island, Bahamas & 74 \\
\hline B. cubensis & & HBG10001-10005 & & Jan 2005 & Eleuthera, Bahamas & 18 \\
\hline B. cubensis & & HBG441/HBG829 & KC-7621/ULLZ-11771 & 2007 & Eleuthera, Bahamas & 2 \\
\hline B. cubensis & & HBG5623-5695 & & Feb-Mar 2016 & Eleuthera, Bahamas & 95 \\
\hline B. cubensis & & HBG3187, HBG7091 & ULLZ-11738 & Jan 2007 & Mayaguana, Bahamas & 3 \\
\hline B. cubensis & & HBG2772-2775 & BS1, BS12, BS19, BS22 & Jan 2003 & Quintana Roo, Mexico & 4 \\
\hline B. cubensis & & $\begin{array}{l}\text { HBG1296-1390, } \\
\text { HBG1762-1906 }\end{array}$ & & Jun 2012 & San Salvador, Bahamas & 158 \\
\hline B. cubensis & & $\begin{array}{l}\text { HBG1391-1694, } \\
\text { HBG1907-1972 }\end{array}$ & & Jun 2013 & San Salvador, Bahamas & 70 \\
\hline B. cubensis & & HBG1977-2124 & & Jun 2014 & & 109 \\
\hline B. cubensis & & $\begin{array}{l}\text { HBG2137-3422, } \\
\text { HBG8151-8160 }\end{array}$ & & Jun 2015 & San Salvador, Bahamas & 115 \\
\hline Barbouria yanezi & Barbouria cubensis & HBG9158-9181 & & Oct 2011 & Cozumel, Q. Roo, Mexico & 24 \\
\hline Janicea antiguensis & Parhippolyte antiguensis & HBG 66 & OUMNH.ZC.2009-15-002 & Apr 2004 & Mayaguana, Bahamas & 1 \\
\hline J. antiguensis & P. antiguensis & $\begin{array}{l}\text { HBG 9999, } \\
\text { HBG10000 }\end{array}$ & TI-19-002 & Mar 2019 & Belize & 2 \\
\hline Parhippolyte cavernicola & & HBG 10136 & USNM-IC-273315 & May 1994 & Baja California Sur, Mexico & 1 \\
\hline Parhippolyte misticia & & HBG 10121 & NTOU-M01675 & Nov 2009 & Japan & 1 \\
\hline P. misticia & & HBG10122-10128 & NTOU-M01157 & Nov 2009 & Dive 22 Shogakko-mae, Japan & 7 \\
\hline Parhippolyte sterreri & & HBG1761-3389 & & Jun 2011 & San Salvador, Bahamas & 53 \\
\hline P. sterreri & & HBG1927-1944 & $\begin{array}{l}\text { USNM-IC-1234891 - USNM- } \\
\text { IC-1234894 }\end{array}$ & Jun 2013 & San Salvador, Bahamas & 4 \\
\hline P. sterreri & & HBG8046-8162 & & Jul 2017 & Acklins Island, Bahamas & 29 \\
\hline Parhippolyte uveae & Parhippolyte misticia & HBG10119 & MNHN-IU-2019-2058 & 1967 & Coral Sea & 1 \\
\hline P. uveae & Parhippolyte misticia & HBG10120 & MNHN-IU-2019-2059 & 1967 & Coral Sea & 1 \\
\hline P. uveae & Parhippolyte misticia & HBG10114 & MNHN-IU-2012-1001 & Mar 1990 & Coral Sea & 1 \\
\hline P. uveae & Parhippolyte misticia & HBG10115 & MNHN-IU-2012-1002 & Mar 1990 & Coral Sea & 1 \\
\hline P. uveae & Parhippolyte misticia & HBG10116-10118 & MNHN 2018-3568 & Mar 1990 & Coral Sea & 3 \\
\hline P. uveae & & $\begin{array}{l}\text { HBG10130, } \\
\text { HBG10134 }\end{array}$ & USNM-IC-280216-85 & Mar 1996 & Aldabra, Seychelles & 2 \\
\hline P. uveae & & HBG10131-10135 & USNM-IC-280216-86 & Mar 1996 & Aldabra, Seychelles & 4 \\
\hline
\end{tabular}




\section{CHAPTER V}

ENDANGERED CAVE SHRIMP REVEAL HIGH CONNECTIVITY DESPITE AN ANCHIALINE ISOLATION PARADIGM ACROSS THE TROPICAL WESTERN ATLANTIC (DECAPODA: CARIDEA: BARBOURIA CUBENSIS) 


\section{ABSTRACT}

Barbouria cubensis is a critically endangered anchialine shrimp distributed across the tropical western Atlantic. Anchialine systems are generally considered to be disjointed, with little to no connectivity between anchialine pools or between islands. The present study analyzes the population structure and genetic diversity of $B$. cubensis from Abaco, Acklins and San Salvador, Bahamas and the Yucatán Peninsula, Mexico to test the isolation paradigm of anchialine systems. Single nucleotide polymorphisms from reduced representation genome-sequencing were examined in 47 individuals from 24 distinct localities and a hybrid de novo partial draft genome assembly was constructed using Illumina short reads and Oxford Nanopore long reads. The results indicated a single population of $B$. cubensis distributed throughout the western Atlantic with low genetic diversity $\left(F_{S T}=0.0033\right)$ and a small effective population size $\left(N_{e}=198\right)$. Such a low $F_{S T}$ value despite their wide distribution suggests that $B$. cubensis has a high level of connectivity between anchialine systems, likely resulting from strong dispersal capabilities. The results also suggest that a partial draft genome can greatly improve downstream analyses in next-generation molecular studies. The ability to use a partial draft genome is particularly valuable in research involving vulnerable or threatened species, or species with large genomes. Our findings also suggest that a disturbance to a single anchialine pool could affect an entire species as a whole, which indicates the need for improved conservation of seemingly disjointed anchialine systems and increased protection of the highly connected and endangered species that call them "home". 


\section{INTRODUCTION}

Isolation has long been recognized as a driving force behind evolution since Charles Darwin first described natural selection in his work on the origin of species (Darwin, 1859). Islands provide a natural laboratory for the study of evolutionary process and patterns across spatially disjunct populations (Edwards, 1996). Akin to the islands on which they are typically found, anchialine systems can offer a similar opportunity to study seemingly isolated populations with unique and sometimes endemic species (Edwards, 1996, Rose et al., 2016; Peréz-Moreno et al., 2016).

Anchialine systems are globally distributed subterranean estuaries with landlocked surficial bodies of water and tidal influence where crustaceans constitute the greatest biodiversity (Culver \& Sket, 2001; Bishop et al., 2015). In spite of tidal influences, anchialine systems have been described as "islands within islands," which fit within an isolation paradigm as a consequence of their lack of biological connectivity with the surrounding environment (Edwards, 1996; Santos, 2006; Porter, 2007; Humpreys et al., 2009; Iliffe \& Kornicker, 2009; Russ, Santos \& Muir, 2010; Becking et al., 2011; Bishop et al., 2015; Dawson, 2016; Gonzalez et al., 2017; Pérez-Moreno et al., 2017). The isolation of anchialine systems has been found to be closely linked with speciation as a result of niche partitioning (Turner et al., 2008; Martin \& Wainwright, 2013; Herman et al., 2018) and geographical barriers to gene flow (Neighbor et al., 2012 Becking et al., 2013; Peréz-Moreno et al., 2016). Isolation caused by geographic barriers (e.g., cave system) has also been demonstrated to cause population and phenotypic differentiation in hypogean systems, which may be an early indicator of evolution processes taking place (Rose et al., 2016; Pérez-Moreno et al., 2017; Herman et al., 
2018). Evidence from the Scaly Pearl Oyster (Pincatada longisquamosa) further suggests that anchialine systems remain relatively isolated except during extreme weather events where geographic barriers may be disrupted (Cole et al., 2007). In contrast to the "islands within islands" hypothesis, a "continuous spelean corridor" hypothesis has been proposed, suggesting anchialine systems are connected within islands on the basis of intra-island gene flow, and limited genetic exchange over small spatial scales (Edwards, 1996; Chace \& Hobbs, 1969; Gonzalez et al., 2017).

Gene flow detected among populations of crustaceans inhabiting similarly isolated environments was found to exist between islands but is highly dependent on marine dispersal capabilities (Kano \& Kase, 2004; Buhay \& Crandall, 2005; Santos, 2006; Zakšek et al., 2009, Cook et al., 2009; Russ et al., 2010; Cutter, 2013). Anchialine species with strong dispersal mechanisms may exhibit genetic exchange between populations up to 200-600 km (Kano \& Kase, 2004; Weese et al., 2013). The tropical western Atlantic is an ideal testing ground for the proposed isolation of anchialine habitats because of their separation by geographic distance, and deep trenches and channels (Culver \& Sket, 2000; Gonzalez et al., 2017).

Barbouria cubensis is critically endangered cave shrimp that has colonized an expansive variety of anchialine localities throughout the western Atlantic (Bishop \& Iliffe 2013). Barbouria cubensis is also relatively unique among anchialine species, because they are believed to have strong dispersal capabilities (Hobbs, 1978; Bauer, 2005; Onaga et al., 2012). The widespread distribution and likely dispersal capabilities of B. cubensis nominates them as an ideal candidate for investigating connectivity patterns among vulnerable anchialine communities and as potential indicator species for the health of 
anchialine habitats (Bohonak, 1999; Kano \& Kase, 2004; Porter, 2007; Becking et al., 2011; Bishop \& Iliffe, 2012; Ditter et al., 2015; Pérez-Moreno et al., 2017; Ditter et al., 2019a). Barbouria cubensis has also been found to exhibit phenotypic hypervariation (PhyV), defined as the presence of extensive morphological variations at rate far beyond the prescribed norm (Ditter et al., 2019b). Phenotypic hypervariation has been hypothesized to be a result of, in part, low genetic diversity, a possible result of severe inbreeding. Barbouria cubensis was found to lack genetic diversity between populations from the Yucatan Peninsula and the Bahamas in the $16 \mathrm{~S}$ and COI mitochondrial gene regions (Ditter et al., 2019; Ditter et al., 2020). Morphological abnormalities have been correlated to low genetic diversity leading to the accumulation of deleterious mutations (O’Grady et al., 2006; Duarte et al., 2008; Fernandes et al., 2011; Lacy \& Alaks, 2012; McMillan et al., 2016). Highly fragmented populations can be susceptible to an increased risk from infectious diseases and loss of genetic diversity, fitness and ability to respond to environmental changes stemming from inbreeding, drift, competition and habitat loss (Wilson, 1985; Brian et al., 2006; Perez-Enriquez et al., 2009; Bazin et al., 2006; Airoldi et al., 2008; Lacy \& Alaks, 2012). Phenotypic hypervariation may be an indicator of low population health and resilience, and a need for immediate conservation efforts.

The advent of next-generation molecular techniques, such as reduced representation genome-sequencing (RADseq) permits unprecedented resolution of a variety of long-standing questions regarding phylogeography and population structure (Davey \& Blaxter, 2010; Juan et al., 2010; Metzker, 2010; Lemmon et al., 2012; Peterson et al., 2012; McCormack et al., 2013). However, the effectiveness of population level analyses using RADseq data is limited in non-model organisms that lack full genome 
sequences, because effective population size $\left(N_{e}\right)$ and linkage distances between markers cannot be calculated accurately (Ekblom \& Galindo, 2011; Hoban et al., 2016). The RADseq datasets that lack a reference genome also generally call fewer SNPs than genome referenced datasets, reducing the calculated inbreeding coefficient $\left(F_{I S}\right)$ and the expected transition-to-transversion ratio $\left(T_{S} / T_{V}\right)$ (Shafer et al., 2017). The lack of a reference genome may also result in underestimates of genetic diversity and introduce genealogical biases from nonrandom haplotype sampling (Arnold et al., 2013).

The current study used a hybrid de novo assembly of Illumina ${ }^{\circledR}$ short read sequences and Oxford Nanopore generated long read sequences to generate a draft genome for Barbouria cubensis. The use of a hybrid de novo genome assembly greatly decreases the number of scaffolds and base call errors, while it increases the accuracy and coverage depth (Austin et al., 2017; Istace et al., 2017; Janser et al., 2017; Tan et al., 2017). Using a full or partial genome when conducting population analyses provides increased resolution by allowing the calculation of linkage disequilibrium, estimating effective population size $\left(N_{e}\right)$ and allows researchers to analyze structural variations within sequences (Slatkin, 2008; Calafell et al., 2001; Li \& Durbin, 2009; Istace et al., 2017).

The objective of the present study is to use next generation molecular techniques to test the isolation paradigms of anchialine systems. By evaluating population dynamics and dispersal abilities of the critically endangered B. cubensis we aim to test the "island within islands" and "spelean corridor" hypothesis. We hope to demonstrate the usefulness of partial genome sequencing by leveraging a hybrid de novo assembled draft genome to evaluate the health of ecosystems and vulnerable species, and to determine if PhyV in $B$. 
cubensis is due to inbreeding and low genetic diversity (Fernandes et al., 2006; Oha \& Paal, 2004; Timm et al., 2020).

\section{METHODS}

\section{SAMPLE SELECTION}

A single freshly preserved specimen of Barbouria cubensis (FICC-HBG-3393) from San Salvador, Bahamas was selected for hybrid de novo assembly of the draft genome. To explore population genomics of $B$. cubensis, 47 individuals representing the broadest geographical distribution of $B$. cubensis housed within the Florida International Crustacean Collection (FICC) were selected from three islands in the Bahamas, Abaco (n=12), Acklins (12), and San Salvador (n=12), and from the Yucatán Peninsula (n=11) (Appendix Table 1). An approximate genome size estimate was generated by averaging C-values for available species on the Animal Genome Size Database that were returned as highly similar to $B$. cubensis from BLASTn queries of $16 \mathrm{~S}$ (rRNA) and H3 (nDNA) gene regions (Altschul et al., 1990; Gregory, 2020). Using the approximate genome size of $\sim 8 \mathrm{Gbp}$ and DNA fragment proportions of enzyme digestions from Agilent BioAnalyzer 2100 (Agilent Technologies) trace results, we determined that a single lane of HiSeq ${ }^{\circledR} 4000$ (Illumina, San Diego, CA, USA) would produce a sufficient number of reads with a least $30 \mathrm{x}$ coverage for 48 individuals.

\section{DNA EXTRACTION}

Genomic DNA was extracted from muscle tissue of the antennule, third to fifth pleopod, or abdomen using DNeasy® Blood and Tissue Kits (Qiagen, Valencia, CA, 
USA), following the manufacturer's protocol. For incomplete tissue digestions, $10 \mu \mathrm{l}$ of Proteinase K and $10 \mu \mathrm{l}$ of 10\% DTT was added, and samples incubated until digestion was complete. Quality of total genomic DNA was visualized using $2 \%$ agarose gels stained with GelRed ${ }^{\circledR}$ (Biotium, Fremont, CA, USA), and concentration was measured using the Qubit dsDNA HS Assay kit on the Qubit 2.0 Fluorometer (Invitrogen, Carlsbad, CA, USA) according to the manufacturer's instructions.

\section{LONG READ SEQUENCING}

To generate genomic long reads, $4.8 \mu \mathrm{g}$ of high molecular weight DNA from FICC-HBG-3393 (see appendix for metadata; Table A1) was cleaned with AMPure XP beads to remove small DNA fragments for sequencing using Oxford Nanopore Technologies Minion device. Long read libraries were prepared using the Rapid Sequencing (SQK-RAD004) kit (Oxford Nanopore). Long read sequencing was performed using two R9.4 flow cells on a MinION Mk1B device with MinKNOW 3.1.3 software, and with base calling performed using Guppy 4.0.11 (Oxford Nanopore). Each flow cell was run four times consecutively for 14 hours using 400-1000 ng of DNA. Flow cells were flushed between each run using a Flow Cell Wash Kit (WSH-002, Oxford Nanopore).

\section{SHORT READ SEQUENCING}

An additional paired end (PE) library was prepared from a single individual (FICC-HBG-3393) using an NEBNext ${ }^{\circledR}$ Ultra $^{\mathrm{TM}}$ II FS DNA Library Prep Kit for Illumina ${ }^{\circledR}$ and NEBNext ${ }^{\circledR}$ Multiplex Oligos for Illumina ${ }^{\circledR}($ E6609S) for use in hybrid de 
novo genome assembly. Samples used for reduced representation library preparation had a minimum of $3000 \mathrm{ng}$ of high molecular weight DNA (metadata list in appendix, Table A1). Library preparation was conducted following a modified protocol for NEBNext® Ultra $^{\mathrm{TM}}$ II FS DNA Library Prep Kit for Illumina (E7805L) and NEBNext® Multiplex Oligos for Illumina® (E6440S) kits (New England Biolabs, Ipswich, MA, USA). AMPure XP Beads (Beckman Coulter, Brea, CA, USA) were used to clean DNA samples. Size selection of 250 bp conducted on a PippinPrep (Sage Science, Beverly, MA, USA) was conducted after PCR enrichment and pooling, with a final AMPure XP bead. Final PE library quality was accessed again using an Agilent BioAnalyzer 2100 before sending the library for 2x150 paired end sequencing with 5\% Phi-X Spike-in on an Illumina HiSeq 4000 by Genewiz (South Plainfield, NJ, USA).

\section{HYBRID DE NOVO ASSEMBLY}

An initial genome size was estimated using PE and Nanopore reads separately using k-mer counting with Jellyfish 2.2.7 (Marçais \& Kingsford, 2011) and GenomeScope 1.0 (Vurture et al., 2017) to visualize k-mer count distribution. The average estimated genome size $(1.8 \mathrm{Gbp})$ was used to assemble raw nanopore reads twice using Canu 1.7.1 (Koren et al., 2017) with corrected error rates of 10.5\% and 14.4\%, respectively. Genome assembly quality evaluation was conducted using QUAST 5.0.2 (Gurevich et al., 2013). The most contiguous assembly was used to re-estimate the genome size ( $4.5 \mathrm{Gbp})$. Raw nanopore reads were then corrected using 10 iterations of Canu -correct with a corrected output coverage of 500, a corrected minimum coverage of 1, corrected Mhap sensitivity at "high", and a genome size of $4.5 \mathrm{Gbp}$ (Koren et al., 
2017). The $10^{\text {th }}$ iteration of read correction was trimmed and assembled using Canu flags -trim and -assemble with utg graph deviation set to 50 and the corrected error rate set to 30\% (Koren et al., 2017). The final genome assembly was indexed and aligned against the corresponding corrected PE using Bowtie2 2.4.1 and polished using Nanopolish 0.13.2 (Altschul et al., 1990; Loman et al., 2015).

\section{SHORT READ FILTERING AND DATA ASSEMBLY}

Raw sequences were processed with the STACKS 2.3d (Catchen et al., 2011; Catchen et al., 2013) pipeline on the FIU High Performance Computing Cluster (HPCC). Any PCR clones were removed using the clone_filter package of Stacks 2.3d while retaining oligos (Catchen et al., 2011). Using the process_shortreads package of Stacks 2.3d, PE reads were demultiplexed, cleaned (-c), quality filtered (-q), chastity/purity filtered (--filter-illumina), and truncated/trimmed to $35 \mathrm{bp}$. The denovo_map.pl pipeline was used to execute the Stacks pipeline (ustacks, cstacks, sstacks, tsv2bam, gstacks, and populations) with allowed number of mismatches allowed between stacks within individuals set to -M 3 and between individuals set to -n 4 (Catchen et al., 2011; Catchen et al., 2013). Additional options of specific pipeline components were passed to the deno_map.pl program using the -X option (-X ustacks:"-M 3 -m 5"). Putative paralogs were excluded by setting the maximum Hamming distance between reads in a stack to 3 and setting the minimum depth of coverage required to create a stack to 5 (Timm et al., 2020). The populations tool was rerun to reduce the total number of loci to between 500 and 1000 (Catchen et al., 2011). Only one random SNP was called per locus to generate a final alignment of SNPs (FSD). All FSD loci were retained by allowing 0\% missing data 
at each site and within each individual. No $F_{S T}$ outliers within the final SNP dataset (FSD) were detected by plotting results of BayeScan v2.1 in R (Foll \& Gaggiotti, 2008).

\section{DRAFT GENOME CHARACTERIZATION}

To assemble the draft genome, a combination of Illumina-sequenced short reads and MinION-generated long reads were mapped together (Austin et al., 2017). For the purposes of the present manuscript, we refer to the de novo assembled SNP dataset(s) as the "BcubSNP", the Barbouria cubensis (FICC-HBG-3393) draft genome (PENDING) referenced SNP assembly dataset(s) as "BcubGNM", and the Palaemon carnicauda (GCA_004011675.1) referenced SNP assembly dataset(s) as "PcarGNM". Paired end reads were aligned to the BcubGNM and PcarGNM assemblies using Bowtie2 2.4.1. Read assembly was conducted de novo, BcubGNM and PcarGNM were referencealigned using the STACKS denovo_map.pl and ref_map.pl pipelines respectively of Stacks 2.5.3 (Fig. 1). To compare assembly methods, 30 BcubSNP, BcubGNM and PcarGNM test datasets each were generated, one random SNP was retained with a maximum of $15 \%$ missing at each locus using populations 2.53 (Fig. 1). For each test dataset (BcubSNP, BcubGNM \& PcarGNM) divergence from Hardy-Weinberg equilibrium for each locus and SNP-based $F$ statistics were calculated as part of the Populations 2.53. No $F_{S T}$ outliers within the BcubSNP, BcubGNM and PcarGNM test datasets were detected by plotting results of BayeScan v2.1 in R (Foll \& Gaggiotti, 2008). Mean F FT values were tested for normality using the Shapiro-Wilk statistics and compared using a one-way ANOVA in R version 3.3.1 (R Core Team, 2016). 


\section{POPULATION GENOMIC ANALYSES}

The analysis suite implemented in GENODIVE 3.04 (Meirmans \& Van Tienderen, 2004) was utilized to calculate population allele frequencies, which determined the distribution that alleles were randomly drawn from to replace missing data of the BcubSNP, BcubGNM and PcarGNM datasets (Eaton et al., 2017). Measures of genetic diversity were calculated within GENODIVE as well as, the inbreeding coefficient $\left(G_{I S}\right)$, Observed, expected and total heterozygosity $\left(H_{O}, H_{S}\right.$ and $H_{T}$, respectively). Each locus was tested for departures from Hardy-Weinberg equilibrium (HWE), using jackknifing to calculate to standard deviation. Hierarchical Analyses of Molecular Variance (AMOVA) and pairwise populations differentiation $\left(F_{S T}\right)$ were calculated in GENODIVE as well. The AMOVA was conducted under the Infinite Alleles Model and significance was assessed over 1000 permutations (Felsenstein, 1985). A single set of SNPs that was closest to the means of the genetic diversity measures from the BcubSNP, BcubGNM and PcarGNM datasets was used to conduct a discriminant analysis of principal components using FastSTRUCTURE (Raj et al., 2014) to assess the impact of each assembly method on the population structure results.

\section{POPULATION STRUCTURE: FINAL SNP DATASET}

The final dataset (FSD) of random snps that was generated with $0 \%$ missing data from the BcubGNM was used to analyze population structure. Using STRUCTURE 2.3.4 (Pritchard et al., 2000) used to analyze k-means clustering. STRUCTURE 2.3.4 was run for 10 iterations for each number of clusters $(K)$ between 2 and 10 for 100,000 generations, with a burn-in of 25,000 generations, and with/without admixture using prior 
population information. Evanno's $\Delta K$ (Evanno, Regnaut, \& Goudet, 2005) was calculated with STRUCTURE HARVESTER (Earl \& vonHoldt, 2012) and used to determine the most likely number of genetic populations. Cluster Matching and Permutation Program (CLUMPP) files generated by STRUCTURE HARVESTER (Earl \& vonHoldt, 2012) were used to average membership probabilities among runs with CLUMPP 1.1 (Jackobson \& Rosenberg, 2007) and the results were visualized with DISTRUCT 1.1 (Rosenberg, 2004) using Clustering Markov Packager Across K with CLUMPAK 1.1 (Kopelman et al., 2015).

The selection coefficient (Tajima's D) was calculated for the SNPs using PopART 1.7.4 (Leigh \& Bryant, 2015). PopART 1.7.4 was also used to generate TCS networks for phased haplotypes and recovered mitochondrial loci (Bandelt et al., 1999; Clement et al., 2002). Effective population size $\left(N_{e}\right)$ using the molecular co-ancestry method of Nomura (2008) was calculated with NeEstimator V2.1 for the draft genome aligned SNPs (Do et al. 2014). Relative migration networks were constructed using the divMigrate function of the R package diveRsity (Jost, 2008; Keenan et al., 2013).

\section{RESULTS}

\section{DRAFT GENOME: LONG READ SEQUENCING AND ASSEMBLY}

We obtained 5,974,504 Oxford Nanopore long reads $(1,383,044,009$ base pairs) from two R9.4 flow cells on a MinION Mk1B device. The R9.4 flow cells produced reads up to $172,000 \mathrm{bp}$ in length and the longest read with $>10 \mathrm{x}$ coverage of was $\sim 95,000$ bp. Ten rounds of Canu -correct resulted in 386,827 reads, representing 1,164,309,982 bases with $0.64 x$ coverage at an estimated genome size of $1.8 \mathrm{Gbp}$. 
After quality filtering and correcting long reads, multiple rounds of CANU assemble was conducted to generate the partial BcubGNM. Our first round of CANU long read genome assembly produced 519 contiguous sequences (contigs) from 149,512 long read sequences with a total length of 408,198,075 bp and an estimated genome size of between 1.5 Gbp and 1.8 Gbp. The second round of CANU long read genome assembly produced 795 contigs with a total length of 5,851,284 bp (N50 13,055; L50 134; Fig. 2).

DRAFT GENOME AND FSD: SHORT READ SEQUENCING

Two lanes of Illumina® HiSeq ${ }^{\circledR} 4000$ run for the BcubGNM and FSD produced over 250 gigabytes of short read sequencing data. We obtained 673,442,914 filtered short reads for FICC-HBG-3393 and 1,529,981,090 filtered short reads for 47 of 48 individuals (excluding FICC-HBG-2773 because of low coverage) analyzed in this study (average 16,276,395, standard deviation 5,974,504; NCBI Bio-project PENDING; NCBI SRA Accessions PENDING).

\section{DRAFT GENOME EVALUATION}

Thirty rounds of de novo (BcubSNP), BcubGNM aligned, and PcarGNM aligned short read assemblies have an average of 358, 6897 and 40 remaining variant sites, respectively (Fig: 1). The proportion of total genetic variance contained within subpopulations $\left(F_{S T}\right)$ exhibit normal distribution and significantly different between each test dataset ( $\mathrm{p}$-value $=3.36968 \times 10^{-12}, \mathrm{df}=29, \alpha=0.05 ;$ Fig. 3 ). We find $F_{S T}$ to be more similar between BcubGNM and PcarGNM datasets. A similar pattern is present among 
other diversity measures except for the number of random SNPs retained (Table $1 \&$ Fig. 3). Populations structure of the BcubSNP, BcubGNM and PcarGNM test datasets examined in fastSTRUCTURE (Pritchard et al., 2010) (Fig. 4A) yield the same results, and suggests an optimal $\mathrm{K}=2-29$, with contribution from one to two groups. For analysis of the 47 individuals using PCA, the first principal component explained $18.1 \%$ of variance and the second principal component explained $12.8 \%$ of variance (Fig. 4B). The PCA clustered individuals from the Bahamas together, whereas some individuals from the Yucatán showed some differentiation.

FINALIZED SNP DATASET (FSD)

After finding improved SNP calling with the BcubGNM referenced loci, we reran diversity measures using the FSD. The BcubGNM aligned short reads produced the FSD with 824 of the 927 variant sites retained and unlink and with $0 \%$ missing data between individuals or within populations.

FSD: POPULATION STRUCTURE ANALYSIS

Population structure of the 47 B. cubensis in the FSD examined with the program STRUCTURE and 827 SNPs with the program ADMIXTURE, found $K=3$ to be optimal using the $\Delta K$ method of Evanno and the optimal number of populations $(Q=2)$ respectively (Fig. 5). Individuals all share a high degree of ancestry from groups one and two with some ancestry from group three, except for two individuals from the Yucatán population that show a high level of ancestry from groups one and three (Fig. 5; top). High levels of admixture are present among all populations (Abaco, Acklins, San 
Salvador, Bahamas and the Yucatán), with some separation between the Bahamas and the Yucatán populations (Fig. 5; bottom). For analysis of the 47 individuals using PCA, the first principal component explained $24.1 \%$ of variance and the second principal component explained $18.2 \%$ of variance (Fig. 5; right). The PCA clustered individuals from the Bahamas and the Yucatán together.

Both the recovered mitochondrial loci and phased haplotype networks reveals a high degree of interrelatedness between populations (Fig. 6; top), with little distinction based on geographic location (Fig. 6; bottom) The overall nucleotide diversity $(\pi)$ is 0.117955, with 607 segregating sites and 440 parsimony-informative sites, and a Tajima's D of -1.2585 (calculated in PopArt 1.7.4).

\section{FSD: GENETIC DIVERSITY}

We find indications of very low genetic diversity among populations of $B$. cubensis $(\pi=0.0538 \pm 0.0049)$ with an average pairwise $F_{S T}$ of $0.0214 \pm 0.0017$, and evidence of outbreeding $\left(G_{I S}=-0.3540 \pm 0.0638\right)$ and very little divergence $\left(\Delta_{X Y}=\right.$ $0.0006 \pm 4.05 \times 10^{-5}$ ) among Abaco, Acklins and San Salvador, Bahamas, and the Yucatán populations (Table 3 and Fig. 7). This suggests that B. cubensis in the tropical western Atlantic represents a single population, possibly with subpopulations in the Bahamas and the Yucatán Peninsula. Genetic diversity values across populations are very similar $\left(H_{O}\right.$ : $\left.0.0482-0.0626 ; H_{S}: 0.0333-0.0475 ; G_{i s}:-0.3093--0.4474\right)$, indicating outbreeding between populations or recent population growth (Table 2). Recalculation of the inbreeding coefficient, treating all sampling localities as single population, resulted in an overall $G_{I S}$ of 0.0033 (Table 3). An analysis of Genetic Membership Probability also 
provides evidence of two mixed subpopulations (Bahamas and Yucatán) within the western Atlantic, with membership probabilities similar to geographic distances (Fig. 8).

The overall effective population size $\left(N_{e}=198\right)$ calculated using linkage disequilibrium (LD) locus pairing across chromosomes for treating all 47 individuals as single population is particularly low considering the wide geographic sampling range and the high densities B. cubensis are reported in (Charlesworth, 2009). When treating the individuals as two subpopulations, the Bahamas and Yucatán we find the effective population sizes of 346.2 and 3.2 respectively. The relative migration networks indicate high magnitudes of migrations from Acklins Island to Abaco, San Salvador and the Yucatán (>0.96). We also find moderate to high magnitudes of migrations between all localities $(0.45-0.96)$.

\section{DISCUSSION}

This research represents the first genomic study to examine diversity and connectivity of enigmatic anchialine crustaceans in the western Atlantic. Using a hybrid of Illumina short reads and Nanopore long reads, we test the anchialine isolation paradigm using Barbouria cubensis (Edwards, 1996; Gonzalez et al., 2017). The idea that inland bodies of water within islands completely lack connectivity is largely based on their differences in colonization patterns, associated species assemblages, salinity regimes and their departure from island biogeographic theory (Edwards, 1996). This complete lack of connectivity is most often supported in studies of organisms that lack planktonic dispersal mechanisms or have undergone sympatric speciation as a result of niche partitioning (Neighbor et al., 2012 Becking et al., 2013; Rose, Masonjones \& 
Jones, 2016). However, when study organisms exhibit some form of weak dispersal or limited planktotrophic larvae, dispersal through crevicular spelean corridors is found, but only within a single land mass (Santos, 2006; Botello \& Álvarez, 2010; Russ et al., 2010; Hunter et al., 2007; Gonzalez et al., 2017). Organisms with intra-island connectivity better fit within the rules of island biogeography theory as island populations are isolated

from one another, and gene flow is restricted over a small spatial scale, but their ability to use spelean corridors does not offer insight into how these organisms are able to colonize island-to-island. Further investigation of anchialine crustaceans has found some species are able to exchange genetic material between islands at distances around $200 \mathrm{~km}$, and in some cases up to $600 \mathrm{~km}$ (Russ et al., 2010; Weese et al., 2016)

\section{GENETIC CONNECTIVITY AND MIGRATION PATTERNS OF BARBOURIA} CUBENSIS ACROSS THE WESTERN ATLANTIC

In spite of a variety of potential barriers to gene flow among anchialine populations in the tropical western Atlantic, we find little evidence of isolation among populations of B. cubensis. Across the Bahamian islands of Abaco, Acklins and San Savlador, and the Yucatán Peninsula, we found evidence of migration, outbreeding and admixture between populations, indicating gene flow exceeding $1200 \mathrm{~km}$. (Table 3). These distances might be somewhat shorter if we consider a Cuban population acting as an intermediate for genetic exchange between the Yucatán and the Bahamas. Despite this possibility, we find evidence of a significant high magnitude of migration between the Bahamas and the Yucatán (Fig. 8). Alternatively, a population to the South of Cuba in Cayman Brac, Cayman Islands or another Caribbean population could be acting as an 
intermediary. The distance between the Yucatán and Cayman Brac is $\sim 760 \mathrm{~km}$, which still exceeds the $600 \mathrm{~km}$ limit previously reported for anchialine crustaceans (Weese $e t$ al., 2016). The direction of water flow in the Atlantic resulting from the Caribbean Current and Florida Current is a potentially important factor to consider in connectivity of species with planktotrophic larvae. Any individuals or larvae emigrating from the Yucatán or the Bahamas could be swept away by the currents and become entrained in the North Atlantic Gyre, where individuals would mix before immigrating to another population (Fig. 8). Our relative migration networks suggest that B. cubensis are exchanging between the Bahamas and the Yucatán, with the shortest possible distances of over $1200 \mathrm{~km}$ (Table 3). This is at least twice the distance of the farthest recorded migration among anchialine species (Weese et al., 2016; Gonzalez et al., 2017). Our findings suggest Acklins is acting as an intermediary for genetic exchange, based on the magnitudes of gene flow between populations. It makes sense that Acklins would be a central hub for individuals after completing a cycle in the North Atlantic Gyre, as it is the first location individuals would reach in the Bahamas.

\section{DISPERSAL ABILITY OF BARBOURIA CUBENSIS}

Observations of numerous small oocytes in an ovigerous female B. cubensis (Hobbs, 1978), the lack of a large yolk on newly hatched zoeae of the Parhippolyte sterreri (Hart \& Manning, 1981) (unpublished data), and the sexual system of Parhippolyte misticia (Clark, 1989) (Onaga, et al., 2012) are indicators that shrimps of the family Barbouriidae Christoffersen, 1987 are likely to exhibit extended planktotrophic larval stages (Bohonak, 1999; Bauer, 2005). The distance B. cubensis is 
traveling between islands within our study and their likely extended planktotrophic larvae suggests that they have strong dispersal mechanisms. Compared to other anchialine shrimps, such as Creaseria morleyi (Botello et al., 2010), Metabeteaeus lohena (Russ et al., 2010) Halocardia rubra (Santos, 2006), and species of Typhlatya (Hunter et al., 2007), the potentially strong dispersal capabilities of barbouriid shrimps appears to be unique. This raises the question of how is B. cubensis able to locate and settle in a suitable habitat after traveling such a long distance across what are thought to be typical barrier to gene flow.

\section{POPULATION STRUCTURE OF BARBOURIA CUBENSIS}

Analysis of genetic structure of $B$. cubensis identified one population in the western Atlantic, with very little genetic differentiation between the Bahamas and the Yucatán. We find equal values of nucleotide diversity and inbreeding coefficients between Abaco, San Salvador and the Yucatán $\left(G_{I S}=-0.309--0.341\right.$ and $\pi=0.0557-$ 0.05 with slightly lower genetic diversity and inbreeding coefficient for Acklins $\left(G_{I S}=-\right.$ $0.447, \pi=0.0466)$. This result indicates the presence of outbreeding among populations. When $G_{I S}$ was recalculated treating B. cubensis within the western Atlantic as a single population we found an inbreeding coefficient of 0.003, and the AMOVA identified 99\% of molecular variance was explained by variance within individuals and only $1 \%$ was explained by variance among regions. Discriminant analysis of principal components revealed high levels of admixture between populations. The results of these analyses all suggest that there is a single highly connected population of $B$. cubensis is the western Atlantic. Similarly, we see highly interconnected branching patterns in both our nuclear 
and mitochondrial based haplotype networks and our analysis of genetic membership found two mixed subpopulations. Our results suggest that there is presently only one population of B. cubensis in the western Atlantic, which may have historically been divided into two to three separate lineages, and that individuals appear to be primarily mixing within Acklins Island, Bahamas.

\section{HOW LOW CAN THEY GO? GENETIC DIVERSITY}

According to our finding genetic diversity $\left(F_{S T}=0.0033\right)$. Our finding suggests that $B$. cubensis has undergone a recent population expansion, which typically occurs following a bottleneck (Provan et al., 2005; Maggs et al., 2008; Campo et al., 2009). This is not that surprising when considering the increased access to existing habitat, and the formation or opening of new anchialine habitats as sea-levels rose following last glacial maxima occurring around 20,000 years ago (Mylroie et al., 1995, Mylroie \& Mylroie, 2011). We also found very low effective population size $\left(N_{e}=198\right)$. Anchialine habitats often occur in areas of high demand for tourism, and are being rapidly altered by development, pollution, and climate change (Iliffe, Jeckells \& Brewer, 1984; Sket, 1999; Iliffe, 2002; Schawbe, Cathcart \& Carew, 2010; Pérez-Moreno et al., 2016). Due to their endemism or restricted distributions anchialine organisms are more easily impacted by disturbances (Humphreys et al., 2009; Bishop \& Iliffe, 2012, Pérez-Moreno et al., 2016). The combination of low genetic diversity and a small effective population size suggests that $B$. cubensis may be vulnerable to future disturbances as a result of their high connectivity resulting from inbreeding depression (Charlesworth \& Charlesworth, 1987; Charlesworth \& Willis, 2009). This is particularly concerning, because of the rampant 
harm anthropogenic effects are having on anchialine systems. While B. cubensis is widespread throughout the tropical western Atlantic, our findings suggest that B. cubensis may be in need of conservation efforts.

\section{VALUE ADDED: PARTIAL DRAFT GENOME}

The use of a hybrid de novo draft genome assembly of Ilumina short reads and Nanopore long reads provided more utility for our short read data and higher resolution with greater accuracy to results. Results of Downstream analyses from more effectively assembled loci better reflect the actual population as a result of reduced nonrandom haplotype sampling bias (Arnold et al., 2013). A comparison of genetic diversity indices for de novo (BcubSNP), Barbouria cubensis draft genome referenced (BcubGNM) and Palaemon carnicuada genome referenced (PcarGNM) assembled datasets suggests that the BcubGNM more closely resembles the PcarGNM and that the BcubGNM likely more closely represents the actual genetic diversity of $B$. cuebensis than the BcubSNP. The genetic diversity measures of the BcubGNM are nearly 3x higher than those of the BcubSNP, which is in line with de novo assembled SNPs underestimating diversity (Arnold et al., 2013). While we found lower genetic diversity and nucleotide diversity in the BcubGNM versus the BcubSNP, we found higher values for all other measures of genetic diversity and significantly more unlinked loci. This also indicates the BcubGNM is more accurate and of greater utility as these loci more closely resemble the actual population of B. cubensis. The BcubSNP implicates the Yucatán as the intermediary for dispersal, while the BcubGNM implicates Acklins, Bahamas as the intermediary for dispersal. This may be the result of bias from higher similarity in sequences between the 
Bahamian populations and the draft genome, as the draft genome was constructed from an individual from San Salvador, Bahamas. However, this is likely not the case, as the PcarGNM implicates both Acklins and San Salvador as intermediaries for dispersal and bias caused by differences in sample size between the Bahamas and the Yucatán. The similarity in which populations are implicated as intermediaries for gene flow lends further support that the use of a partial draft genome improves SNP assembly and downstream analyses. Overall, our results suggest that even the use of a partial draft genome greatly reduces the biases associated de novo assembled short read datasets, and yields results comparable to complete reference genome assembled dataset. For little extra cost, the use of a draft genome also offers greater value and utility in downstream analyses of genomic datasets by providing the ability to calculate linkage distances.

\section{CONCLUSION}

We propose a new "anchialine isolation by dispersal" hypothesis to explain how different species inhabiting the same anchialine systems can exhibit a range connectivity patterns, from complete isolation to intra-island gene flow to high levels of genetic exchange between geographically distant populations. Simply stated, the more time that the larvae of a species spends in the water column before settling out the greater distance the larvae will travel, ultimately leading to a greater likelihood of genetic connectivity among populations. Larval dispersal mechanisms of a given organisms is the primary determining factor if populations among anchialine systems will exhibit an isolated population structure or genetic connectivity over a range of geographic distances, initially described by Weese, Fuijita and Santos (2016). In the case of a species suspected of 
having strong dispersal capabilities, like B. cubensis, we would expect and found high inter-island connectivity across vast geographic distances.

When it comes to population genomics and the current technology available, having a complete reference genome is the best option. Regrettably, when working with non-model species or species with large genomes a complete high coverage genome sequence is not typically available. Fortunately, low cost sequencing platforms are available to generate long read data that can be combined with short reads to assemble a draft genome. Even a partial draft genome can vastly improve the resolution of downstream analyses, increase the utility of short read sequencing data and has little extra cost. This is especially valuable in studies that include vulnerable species or habitats that may be in need of conservation efforts.

\section{ACKNOWLEDGMENTS}

We would like to thank Drs. Thomas Iliffe, Craig Layman, Jocelyn Curtis-Quick and the Cape Eleuthera Institute, The Bahamas for their assistance in the collection of material from the Yucatán Peninsula, and Abaco and Eleuthera, Bahamas (respectively). We are grateful for the support and assistance of the Gerace Research Centre, San Salvador, Bahamas and the Bahamian citizens during field work. This study was supported in part by a student research award from the Gerace Research Centre, The Crustacean Society's Graduate Student Fellowship, The National Speleological Society Ralph Stone Graduate Fellowship Grant, and Florida International University Tropics graduate research grant awarded to RED. Additional support was provided by Florida International University. LMMO thanks the Consejo Nacional de Ciencia y Tecnología (CONACYT), Mexico to 
support the exploration in karstic areas in Mexico by funding the project CONACYT-

258494 (Fondo Sectorial de Investigación para la Educación).

\section{REFERENCES}

Airoldi, L., Balata, D. and Beck, M.W. (2008). The Gray Zone: Relationships between habitat loss and marine diversity and their applications in conservation. Journal of Experimental Marine Biology and Ecology, 366:8-15.

Altschul, S.F., Gish, W., Miller, W., Myers, E.W. and Lipman, D.J. (1990). Basic local alignment search tool. Journal of Molecular Biology, 215(3):403-410.

Austin, C.M., Tan, M.H, Harrison, K.A., Lee, Y.P., Croft, L.J., Sunnucks, P., Pavlova, A. and Gan, H.M. (2017). De novo genome assembly and annotation of Australia's largest freshwater fish, the Murray cod (Maccullochella peelii), from Illumina and Nanopore sequencing read. GigaScience, 6(8):1-6.

Arnold, B. Corbett-Detig, Hartl, D. and Bombles, K. (2013). RADseq underestimates diversity and introduces genealogical biases due to nonrandom haplotype sampling. Molecular Ecology, 22:3179-3190.

Bandelt, H., Forster, P. and Röhl, A. (1999). Median-joining networks for inferring intraspecific phylogenies. Molecular Biology and Evolution, 16(1):37-48.

Bauer, R.T. (2005). Volume 7, Library of Congress Cataloging-In-Publication Data Remarkable Shrimps: Adaptations and Natural History of the Carideans. Animal nat. V.H. Hutchison (Ed.), University of Oklahoma Press: Norman, Norman, Ok.

Bazin, E., Glémin, S. and Galtier, N. (2006). Population size does not influence mitochondrial genetic diversity in animals. Science 312:570-572. doi: 10.1126/science. 1122033

Becking, L.E., Erpenbeck, D., Peijnenburg, K.T.C.A. and de Voogd, N. (2013). Phylogeography of the Sponge Suberites diversicolor in Indonesia: Insights into the Evolution of Marine Lake Populations. PLoS ONE:8(10):e75996.

Becking, L.E., Renema, W., Santodomingo, N.K., Hoeksema, B.W., Tuti, Y. and de Voogd, N.J. (2011) Recently discovered landlocked basins in Indonesia reveal high habitat diversity in anchialine systems. Hydrobiologia, 677(1):89-105. 
Bishop, R.E., Humphreys, W.F., Cukrov, N., Žic, V., BOXSHALL, G.A., Cukrov, M., Iliffe, T.M., Kršinić, F., Moore, W.S., Pohlman, J.W., Sket, B., Bishop, R.E., Kršinić, F., Sket, B., Iliffe, T.M., Žic, V., Moore, W.S., Cukrov, N., Cukrov, M., BOXSHALL, G.A. and Pohlman, J.W. (2015). 'Anchialine' redefined as a subterranean estuary in a crevicular or cavernous geological setting. Journal of Crustacean Biology, 35(4):511-514.

Bishop, R.E. and Iliffe, T.M. (2012). Ecological physiology of the anchialine s.hrimp Barbouria cubensis: a comparison of epigean and hypogean populations. Marine Biodiversity, 42, 303-310.

Bohonak, A.J. (1999). Dispersal, Gene Flow, and Population Structure. The Quarterly Review of Biology, 74(1):21-45.

Botello, A., Iliffe, T.M., Alvarez, F., Juan, C., Pons, J. and Jaume, D. (2013). Historical biogeography and phylogeny of Typhlatya cave shrimps (Decapoda: Atyidae) based on mitochondrial and nuclear data. Journal of Biogeography, 40:594-607.

Botello, A. and Álvarez, F. (2010). Genetic variation in the stygobitic shrimp Creaseria morleyi (Decapoda: Palaemonidae), evidence of bottlenecks and re-invasions in the Yucatan Peninsula. Biological Journal of the Linnean Society, 99:315-325.

Borradaile, L.A. (1900). On some Crustaceans from the South Pacific. Part IV. The crabs. Proceedings of the General Meetings for the Scientific Business of the Zoological Society of London, 1900 (3):568-596.

Brian, J.V., Fernandes, T., Ladle, R.J. and Todd, P.A. (2006). Patterns of morphological and genetic variability in UK populations of the shore crab, Carcinus maenas Linnaeus, 1758 (Crustacea: Decapoda: Brachyura). Journal of Experimental Marine Biology and Ecology, 329(1): 47-54.

Buhay, J.E. and Crandall, K.A. (2005). Subterranean phylogeography of freshwater crayfishes shows extensive gene flow and surprisingly large population sizes. Molecular Ecology, 14:4259-4273.

Calafell, F., Grigorenko, E.L. and Chikanian, A.A. (2001). Haplotype Evolution and Linkage Disequilibrium: A Simulation Study. Human Heredity, 51:85-96.

Campo, D., J. Molares, J., Garcia, L., Fernandez-Rueda, P., Garcia-Gonzalez C. and Garcia-Vazquez, E. (2009). Phylogeography of the European stalked barnacle (Pollicipes pollicipes): Identification of glacial refugia. Marine Biology, 157:147156. 
Catchen, J., Hohenlohe, P., Bassham, S., Amores, A. and Cresko, W. (2013). Stacks: an analysis tool set for population genomics. Molecular Ecology, 22:3124-3140. DOI: $10.1111 / \mathrm{mec} .12354$

Catchen, J., A. Amores, P. Hohenlohe, W. Cresko, and J. Postlethwait. (2011). Stacks: building and genotyping loci de novo from short-read sequences. G3: Genes, Genomes, Genetics, 1:171-182.

Chace, F.A. and Hobbs, H.H. (1969). The freshwater and terrestrial decapod crustaceans of the West Indies with special reference to Dominica. U.S. National Museum Bulletin, 292:1-258.

Charlesworth, B. (2009). Effective population size and patterns of molecular evolution and variation. Nature Reviews Genetics, 10:195-205.

Charlesworth, B. and Willis, J.H. (2009). The genetics of inbreeding depression. Nature Reviews Genetics, 10:783-796.

Charlesworth, D. and Charlesworth, B. (1987). Inbreeding depression and its evolutionary consequences. Annual Review of Ecology and Systematics, 18:237268.

Christoffersen, M.L. (1987). Phylogenetic relationships of hippolytid genera, with an assignment of new families for the Crangonoidea and Alpheoidea (Crustacea, Decapoda, Caridea). - Cladistics 3:348362

Clark, J. (1989). Koror misticius, new genus, new species (Decapoda: Hippolytidae), a cave shrimp from Palau. Journal of Crustacean Biology, 9(3):445-452.

Clement, M., Snell, Q., Walke, P., Posada D. and Crandall, K. (2002). TCS: estimating gene genealogies. Proceedings of the 16th International Parallel Distributed Process Symposium, 2:184.

Cole, E., Hoft, N. and Campion, J. (2007). The effect of hurricane activity on scaly pearl oysters, Pinctada longisquamosa, in two dissimilar inland marine ponds on San Salvador Island, Bahamas. Proceedings of the Symposium on the Natural History of the Bahamas, 11:78-89.

Cook, B.D, Bernays, S., Pringle, C.M. and Hughes, J.M. (2009). Marine dispersal determines the genetic population structure of migratory stream fauna of Puerto Rico: evidence for island-scale population recovery processes. Journal of the National America Bethological Society, 28(3):709-718.

Culver, D.C. and Sket, B. (2000). Hotspots of subterranean biodiversity in caves and wells. Journal of Cave and Karst Studies, 62:11-17. 
Cutter, A.D. (2013). Integrating phylogenetics, phylogeography and population genetics through genomes and evolutionary theory. Molecular Phylogenetics and Evolution, 69:1172-1185.

Davey, J.W. and Blaxter, M.L. (2010). RADseq: next-generation population genetics. Briefings in Functional Genomics, 9(5):416-423.

Dawson, M.N. (2016) Island and island-like marine environments. Global Ecology and Biogeography, 25:831-846. doi:10.1111/geb.12314

Darwin, C. (1859). On the origin of species by means of natural selection, or, The preservation of favoured races in the struggle for life. London: J. Murrary.

Ditter, R. E., Snyder, A. P., Schulman, S. E., and Bracken-Grissom, H. D. (2019a). Notes on the behavior and first records of three enigmatic anchialine shrimps (Decapoda: Caridea: Barbouriidae, Palaemonidae) in the Bahamas. Journal of Crustacean Biology, 39(6): 684-688.

Ditter, R. E., Erdman, R. B., Goebel, A. M., and Bracken-Grissom, H. D. (2019b). Widespread phenotypic hypervariation in the enigmatic anchialine shrimp Barbouria cubensis (Decapoda: Barbouriidae). Zootaxa, 4648(1): 1-26.

Ditter, R.E., Goebel, A.M. \& Erdman, R.B. 2015. First record of the anchialine shrimp Parhippolyte sterreri (Decapoda, Barbouriidae) from San Salvador Island, Bahamas, with observations on Barbouria cubensis. Marine Biodiversity Records, 8:e46. doi:10.1017/S1755267215000196

Do, C., Waples, R.S., Peel, D., Macbeth, G.M., Tillett, B.J. and Ovenden, J.R. (2014). NeEstimator V2: re-implementation of software for the estimation of contemporary effective population size ( $\mathrm{Ne}$ ) from genetic data. Molecular Ecology Resources. 14:209-214.

Duarte, M.S., Maia-Lima, F.A. \& Molina, W.F. (2008). Interpopulational morphological analyses and fluctuating asymmetry in the brackish crab Cardisoma guanhumi Latreille (Decapoda, Gecarcinidae), on the Brazilian Northeast coastline. PanAmerican Journal of Aquatic Sciences, 3 (3):294-303.

Earl, D.A., and vonHoldt, B.M. (2012). STRUCTURE HARVESTER: A website and program for visualizing STRUCTURE output and implementing the Evanno method. Conservation Genetics Resources, 4:359-361.

Eaton, D.A.R., Spriggs, E.L., Park, B. and Donoghue, M.J. (2017). Misconceptions on Missing Data in RAD-seq Phylogenetics with a Deep-scape Example from Flowering Plants. Systematic Biology, 66(3):399-412. doi:10.1093/sysbio/syw092 
Eaton, D.A.R. and Ree, R.H. (2013). Inferring Phylogeny and Introgression using RADseq Data: An Example from Flowering Plants (Pedicularis: Orobanchaceae). Systematic Biology, 62:689-706.

Ekblom, R. and Galindo, J. (2011). Application of next generation sequencing in molecular ecology of non-model organisms. Heredity, 107:1-15.

Evanno, G., Regnaut, S., and Goudet, J. (2005). Detecting the number of clusters of individuals using the software STRUCTURE: A simulation study. Molecular Ecology, 14:2611-2620.

Felsenstein, J. (1985). Confidence limits on phylogenies: an approach using the bootstrap. Evolution, 39:783-791.

Fernandes, C.M., Gregati, R.A. and Bichuette, M.E. (2011). The first record of external abnormalities in the subterranean Aegla marginata Bond-Buckup \& Buckup, 1994 (Crustacea: Decapoda: Aeglidae), from a karst area of Southeastern Brazil. Subterranean Biology, 8:33-38.

Foll, M. and Gaggiotti, O.E. (2006). Identifying the environmental factors that determine the genetic structure of populations. Genetics. 2006, 174:875-91.

Gonzalez, B.C., Martínez, A., Borda, E., Iliffe, T.M., Fontaneto, D. and Worsaae, K. (2017). Genetic Spatial Structure of an anchialine cave annelid indicates connectivity within - but not between - islands of the Great Bahamas Bank. Mol Phylogenet Evol, 109:259-270.

Gregory, T.R. (2020). Animal Genome Size Database. http://www.genomesize.com.

Gurevich, A., Saveliev, V., Vyahhi, N. and Tesler, G. (2013). QUAST: quality assessment tool for genome assemblies. Bioinformatics, 29(8): 072-1075. doi:10.1093/bioinformatics/btt086.

Hart, C.W.J. and Manning, R.B. (1981). The cavernicoulous caridean shrimps of Bermuda (Alpheidae, Hippolytidae, and Atyidae). Journal of Crustacean Biology. 1:441-456.

Hedrick, P.W. (2005). A standardized genetic differentiation measure. Evolution, 59:1633-1638. 
Herman, A., Yaniv Brandvain, Y., Weagley, J., Jeffery, W.R., Keene, A.C., Kono, T.J.Y, Bilandžija, H., Borowsky, R., Espinasa, L., O’Quin, K., Ornelas-García, C.P., Yoshizawa, M. Carlson, B., Maldonado, E., Gross, J.B., Cartwright, R.A., Rohner, N., Warren, W.C. and McGaugh, S.E. (2018). The role of gene flow in rapid and repeated evolution of cave-related traits in Mexican tetra, Astyanax mexicanus. Molecular Ecology, 27:4397-4416. DOI: 10.1111/mec.14877

Hoban, S., Kelley, J.L., Lotterhos, K.E., Antolin, M.F., Bradburd, G., Lowry, D.B., Poss, M.L., Reed, L.K., Storfer, A. \& Whitlock, M.C. (2016). Find the genomic basis of local adaptation: Pitfalls, practical solutions, and future directions. The American Naturalist, 188(4):379-397.

Hobbs, H.H. III. (1978). The female of Barbouria cubensis (von Martens) (Decapoda, Hippolytidae) with notes on a population in the Bahamas. Crustaceana, 35(1): 99-102.

Humphreys, W.F., Watts, C.H.S., Cooper, S.J.B and Leijs, R. (2009). Groundwater estuaries of salt lakes: buried pools of endemic biodiversity on the western plateau, Australia. Hydrobiologia, 626:79-95.

Hunter, R.L., Webb, M.S., Iliffe, T.M. and Bremer, J.R.A., (2007). Phylogeny and historical biogeography of the cave-adapted shrimp genus Typhlatya (Atyidae) in the Caribbean Sea and western Atlantic. Journal of Biogeography, 35:65-75. doi:10.1111/j.1365-2699.2007.01767.x

Iliffe, T.M. \& Kornicker, L.S. 2009. Worldwide diving discoveries of living fossil animals from the depths of anchialine and marine caves. Smithsonian Contributions to Marine Sciences, 38:269-280.

Iliffe, T.M., (2002). Conservation of anchialine cave biodiversity. In: Proceedings of the Symposium Karst Frontiers, 7:99-102.

Iliffe, T.M., Jickells, T. and Brewer, M. (1984). Organic pollution of an inland marine cave from Bermuda. Marine Environmental Research, 12:173-189.

Istace, B. A. Friedrich, L. d'Agata, S. Faye, E. Payen, O. Beluche, C. Caradec, S. Davidas, C. Cruaud, G. Liti, A. Lemainque, S. Engelen, P. Wincker, J. Schacherer and J.-M. Aury. 2017. de novo assembly and population genomic survey of natural yeast isolates with the Oxford Nanopore MinION sequencer. GigaScience, 6(2), 1-13.

Jakobsson, M., and Rosenberg, N.A. (2007). CLUMPP: A cluster matching and permutation program for dealing with label switching and multimodality in analysis of population structure. Bioinformatics, 23:1801-1806. 
Janser, H.J., M. Liem, S.A. Jong-Raadsen, S. Dufour, F.-A. Weltszien, W. Swinkels, A. Koelewijn, A.P. Palstra, B. Pelster, H.P. Spaink, G.E. Van den Thillart, R.P. Dirks and C.V. Henkel. (2017). Rapid de novo assembly of the European eel genome from nanopore sequencing reads. Nature Scientific Reports, 7, 7213.

Juan, C., Guzik, M.T., Jaume, D. and Cooper, S.J.B. (2010). Evolution in caves: Darwin's 'wrecks of ancient life' in the molecular era. Molecular Ecology, 19:3865-3880.

Jost, L. (2008). GST and its relatives do not measure differentiation. Molecular Ecology, $17 ; 4015-4026$.

Kano, Y. and Kase, T. (2004). Genetic exchange between anchialine cave populations by means of larval dispersal: The case of a new gastropod species Neritilia cavernicola. Zoologica Scripta, 33 (5), 423-437.

Keenan, K., McGinnity, P., Cross, T.F., Crozier, W.W. and Prodöhl, P.A. (2013). An R package for the estimation and exploration of population genetics parameters and their associated errors. Methods in Ecology and Evolution, 4:782-788.

Kopelman, N.M., Mayzel, J., Jakobsson, M, Rosenberg, N. and Mayrose, I. (2015). Clumpak: a program for identifying clustering modes and packaging population structure inferences across K. Molecular Ecology Resources, 15(5): 1179-1191. doi:10.1111/1755-0998.12387

Koren, S., Walenz, B.P., Berlin, K., Miller, J.R. and Phillippy, A.M. (2017). Canu: scalable and accurate long-read assembly via adaptive k-mer weighting and repeat separation. Genome Research, 27:722-736.

Kronholm, I., Loudet, O. and de Meaux, J. (2010). Influence of mutation rate on estimators of genetic differentiation-lessons from Arabidopsis thaliana. BMC Genetics, 11:33.

Lacy, R.C. and Alaks, G. (2012). Effects of inbreeding on skeletal size and fluctuating asymmetry of Peromyscus polionotus mice. Zoo Biology, 32(2):125-133.

Leigh, J.W. and Bryant, D. (2015). PopART: Full-feature software for haplotype network construction. Methods in Ecology and Evolution, 6(9):1110-1116.

Lemmon, A.R., Emme, S.A. and Lemmon, E.M. (2012). Anchored hybrid enrichment for massively high-throughput phylogenomics. Systematic Biology, 61:727-744.

Li, H. and Durbin, R. (2009). Fast and accurate short read alignment with BurrowsWheeler transform. Bioinformatics, 25(14):1754-60. 
Loman, N.J., Quick, J. and Simpson, J.T. (2015). A complete bacterial genome assembled de novo using only nanopore sequencing data. Nature Methods, 12(8):733-736. doi:10.1038/nmeth.3444

Maggs, C.A., Castilho, R., Foltz, D., Henzler, C., Jolly, M.T., Kelly, J. and Wares, J. (2008). Evaluating signatures of glacial refugia for North Atlantic benthic marine taxa. Ecology, 89:S108-S122.

Manning, R.B. and Hart, C.W. (1984). The status of the hippolytid shrimp genera Barbouria and Ligur (Crustacea: Decapoda): A Reevaluation. Proceedings of the Biological Society of Washington, 97: 655-665.

Marçais, G. and Kingsford, C. (2011). A fast, lock-free approach for efficient parallel counting of occurrences of k-mers. Bioinformatics, 27(6):764-770.

Martin, C.H. and Wainwright, P.C. (2013). Multiple fitness peaks on the Adaptive landscape drive adaptive radiation in the wild. Science, 339:208-211. doi: 10.1126/science. 1227710

Martens, E., von (1872). Über cubanische Crustaceen nach den Sammlungen Dr. J. Gundlach's. Archiv für Naturgeschichte, 38(1):77-147, Plates 4-5.

McCormack, J.E., Hird, S.M., Zellmer, A.J., Carstens, B.C. \& Brumfield, R.T (2013). Application of next-generation sequencing to phylogeography and phylogenetics. Molecular Phylogenetics and Evolution, 66(2), 526-538.

McKinney, G.J., Larson, W.A., Seeb, L.W. and Seeb, J.E. (2017). RADseq provides unprecedented instights into molecular ecology and evolutionary genetics: comment on Breaking RAD by Lowry et al. (2016). Molecular Ecology Resource, 17:356-361. doi:10.1111/1755-0998.12649

McMillan, A.M., Bagley, M.J., Jackson, S.A. and Nacci, D.E. (2006). Genetic diversity and structure of an estuarine fish (Fundulus heteroclitus) indigenous to sites associated with a highly contaminated urban harbor. Ecotoxicology, 15:539-548.

Meirmans, P.G. and Hedrick, P.W. (2011). Assessing population structure: FST and related measures. Molecular Ecology Resources, 11:5-18.

Meirmans, P.G. and Van Tienderen, P.H. (2004). GENOTYPE and GENODIVE: two programs for the analysis of genetic diversity of asexual organisms. Molecular Ecology Notes, 4:792-794. doi:10.1111/j.1471-826.2004.00770.x

Metzker, M.L. (2010). Sequencing technologies-the next generation. Nature Reviews Genetics, 11:31-46. 
Mylroie, J.R. and Mylroie, J.E. (2011). Development of the carbonate island karst model. Journal of Cave and Karst Studies, 69(1):59-75.

Mylroie, J.E., Carew, J.L. and Edward, F.F. (1995). Development of flank margin caves on San Salvador Island, Bahamas and Isla De Mona, Puerto Rico. Proceedings of the Symposium on the Geology of the Bahamas. 7:49-81.

Nei, M. (1973). Analysis of gene diversity in subdivided populations. Proceedings of the National Academy of Sciences, 70:3321-3323.

Neiber, M.T., Hansen, F.C., Iliffe, T.M., Gonzalez, B.C. \& Koenemann, S. (2012). Molecular taxonomy of Speleonectes fuchscockburni, a new pseudocryptic species of Remipedia (Crustacea) from an Anchialine cave system on the Yucatán Peninsula, Quintana Roo, Mexico. Zootaxa, 3190:31-46.

Nordborg, M. (2001). Coalescent theory. In Handbook of Statistical Genetics Edited by: Balding DJ, Bishop MJ, Cannings C. New York: John Wiley \& Sons, Inc, 2001:179-208.

Nomura, T. (2008). Estimation of effective number of breeders from molecular coancenstry of single cohort smaple. Evolutionary Applications, 1:462-474.

O’Grady, J.J., Brook, B.W., Reed, D.H., Ballou, J.D., Tonkyn, D.W. and Frankham, R. (2006). Realistic levels of inbreeding depression strongly affect extinction risk in wild populations. Biological Conservation, 133(1):42-51.

Oha, T. and Paal, J. (2004). Multivariate analysis of morphological variation among closely related species Bromus Japonicus, B. squarrosus and B. arvensis (Paceae) in comparison with isozyme evidence. Nordic Journal of Botany, 24(6):691-702.

Onaga, H., Fiedler, C.G. and Baeza, A. (2012). Protandrix simultaneous hermaphroditism in Parhippolyte misticia (Clark, 1989) (Caridea: Hippolytidae): implications for the evolution of mixed sexual systems in shrimp. Journal of Crustacean Biology, 23(3):383-394.

Perez-Enriquez, R., Hernández-Martínez, F. and Cruz, P. (2009). Genetic diversity status of White shrimp Penaeus (Litopenaeus) vannamei broodstock in Mexico. Aquaculture, 297:44-50.

Pérez-Moreno, J.L., Iliffe, T.M. \& Bracken-Grissom, H.D. (2016). Life in the Underworld: Anchialine cave biology in the era of speleogenomics. International Journal of Speleology, 45(2):149-170. 
Pérez-Moreno, J.L., Balázs, G., Wilkins, B., Herczeg, G. and Bracken-Grissom, H.D. (2017). The role of isolation on contrasting phylogeographic patterns in two cave crustaceans. BMC Evolutionary Biology, 17:247. doi: 10.1186/s12862-017-10949

Peterson, B.K., Weber, J.N., Kay, E.H., Fisher, H.S. and Hoekstra, H.E. (2012). Double digest RADseq: an inexpensive method for de novo SNP discovery and genotyping in model and non-model species. PLoS ONE, 7(5):e37135.

Porter M.L. (2007). Subterranean biogeography: what have we learned from molecular techniques. J Caves Karst Stud. 69(1):179-186.

Pritchard, J.K., Stephens, M., and Donnelly, P. (2000). Inference of population structure using multilocus genotype data. Genetics, 155:945-959.

Pritchard, J.K., Pickrell, J.K., and Coop, G. (2010). The genetics of human adaptation: hard sweeps, soft sweeps, and polygenic adaptation. Current Biology, 20:R208R215.

Provan, J., Wattier R.A. and Maggs, C.A. (2005). Phylogeographic analysis of the red seaweed Palmaria palmata reveals a Pleistocene marine glacial refugium in the English Channel. Molecular Ecology, 14:793-803.

R Core Team (2016). R: A language and environment for statistical computing. R Foundation for Statistical Computing, Vienna, Austria, Available from: https://www.R-project.org/

Raj, A., Stephens, M. and Pritchard, J.K. (2014). fastSTRUCTURE: Variational inference of population structure in large SNP data sets. Genetics, 197(2):573589. doi: 10.1534/genetics.114.164350

Rathbun, M.J. (1912) Some Cuban Crustacea, with notes on the Astacidae by Walter Faxon, and a list of Isopoda, by Harriet Richardson. Bulletin of the Museum of Comparative Zoology, 54 (15), 451-460, Pls. 1-5.

Rose, E., Masonjones, H.D. and Jones, A.G. (2016). A DNA-Based Assessment of the Phylogenetic Position of a Morphologically Distinct, Anchialine-Lake-Restricted Seahorse. Journal of Heredity, 107(6):553-558. doi:10.1093/jhered/esw048

Rosenberg, N.A. (2004). DISTRUCT: A program for the graphical display of population structure. Molecular Ecology Notes, 4:137-138.

Russ, A., Santos, S.R. and Muir, C. (2010). Genetic population structure of an anchialine shrimp, Metabetaeus lohena (Crustacea: Alpheidae), in the Hawaiian Islands. Revista de Biología Tropical, 58(1):159-170. 
Santos, S.R. (2006). Patterns of genetic connectivity among anchialine habitats: a case study of the endemic Hawaiian shrimp Halocaridina rubra on the island of Hawaii. Molecular Ecology, 15:2699-2718.

Schawbe, S.J., Cathcart, E.M. and Carew, J.L. (2010). Elevated levels of heavy metals detected in mordern soils and flooded-cave sediment from the Bahamas. In: Proceedings of the 14th Symposium on the Geology of the Bahamas and other Carbonate Regions, pp. 209-219.

Shafer, A.B.A., Peart, C.R., Tusso, S., Maayan, I., Brelsford, A., Wheat, C.W., Wolf, J.B.W. (2017). Bioinformatic processing of RAD-seq data dramatically impacts downstream population genetic inference. Methods in Ecology and Evolution, 8:907-917.

Sket, B. (1999). The nature of biodiversity in hypogean waters and how it is endangered. Biodiversity and Conservation, 8(10):1319-1338.

Sket, B. (1996). The ecology of anchihaline caves. Trends in Ecology \& Evolution, 11(5):221-225.

Slatkin, M. (2008). Linkage disequilibrium - understanding the evolutionary past and mapping the medical future. Nature Reviews Genetics, 9:477-485.

Tan, M.H., Austin, C.M., Hammer, M.P., Lee, Y.P., Croft, L.J. and Gan, H.M. (2017). Finding Nemo: Hybrid assembly with Oxford Nanopore and Illumina reads greatly improves the Clownfish (Amphiprion ocellaris) genome assembly. GigaScience, gix 137.

Timm, L.E., Backen-Grissom, H.D., Sosnowski, A., Breitbart, M., Vecchione, M. and Judkins, H. (2020a). Population genomics of three deep-sea cephalopod species reveals connectivity between the Gulf of Mexico and the northwestern Atlantic Ocean. Deep-Sea Research I, 158(103222).1-10.

Timm, L.E., Isma, L.M., Johnston, M.W. and Bracken-Grissom, H.D. (2020b). Comparative population genomics and biophysical modeling of shrimp migration in the Gulf of Mexico reveals current-mediated connectivity. Frontiers in Marine Science, 7(19):1-16.

Timm, L.E. \& Bracken-Grissom H.D. (2015). The forest for the trees: Evaluating molecular phylogenies with an emphasis on higher-level decapoda. J Crust Biol, 35(5), 577-592. 
Turner, B.J., Duvernell, D.D., Bunt, T.M. and Barton, M.G. (2008). Reproductive isolation among endemic pupfishes (Cyprinodon) on San Salvador Island, Bahamas: microsatellite evidence. Biological Journal of the Linnean Soceity, 95:566-582. With 5 Figures

Vurture, G.W., Sedlazeck, F.J., Nattestad, M., Underwood, C.J., Fang, H., Gurtowski, J. and Schatz, M.C. (2017). GenomeScope: fast reference-free genome profiling from short reads. Bioinformatics, 33(14): 2202-2204. doi.org/10.1093/bioinformatics/btx153

Weese, D.A., Fujita,Y. \& Santos, S.R. (2013). Multipe Colonizations Lead to Cryptic Biodiversity in an Island Ecosystem: Comparative Phylogeography of Anchialine Shrimp Species in the Ryukyu Archipelago, Japan. Biological Bulletin, 225:2441.

Wilson, E.O. (1985) The biological diversity crisis. BioScience, 35(11):700-706.

Wright, S. (1969). Evolution and the Genetics of Populations, Vol. 2. University of Chicago Press, Chicago.

Zakšek, V., Sket, B. Gottstein, S. Franjević and Trontelj, P. (2009). The limits of cryptic diversity in groundwater phylogeography of the cave shrimp Troglocaris anophythalmus (Crustacea: Decapoda: Atyidae). Molecular Ecology, 18:931-946. 


\section{TABLES}

Table 1. Mean measures of genetic diversity for 47 Barbouria cubensis from four geographical populations calculated from random unlinked single nucleotide polymorphic loci or the BcubSNP, BcubGNM, and PcarGNM datasets (generated with identical "populations" 2.53 parameters).

\begin{tabular}{clccccccc}
\hline Assembly type & Population & $\boldsymbol{H}_{\boldsymbol{O}}$ & $\boldsymbol{H}_{\boldsymbol{S}}$ & $\boldsymbol{F}_{\boldsymbol{I S}}$ & $\boldsymbol{\pi}$ & $\boldsymbol{N}_{\boldsymbol{e}}$ & $\boldsymbol{A}_{\boldsymbol{m}}$ & $\boldsymbol{A}_{\boldsymbol{P}}$ \\
\hline \multirow{4}{*}{ de novo } & Abaco & 0.5670 & 0.3246 & -0.7470 & 0.3304 & 1.6140 & 273 & 22 \\
& San Salvador & 0.5603 & 0.3187 & -0.7580 & 0.3364 & 1.6090 & 237 & 11 \\
& Acklins & 0.5615 & 0.3276 & -0.7140 & 0.3346 & 1.6140 & 280 & 42 \\
& Yucatan & 0.4678 & 0.3182 & -0.4700 & 0.2941 & 1.5950 & 156 & 9 \\
\hline \multirow{5}{*}{ draft genome aligned } & Abaco & 0.0884 & 0.0700 & -0.2633 & 0.1034 & 1.1000 & 2858 & 1129 \\
& San Salvador & 0.0891 & 0.0709 & -0.2563 & 0.1051 & 1.1010 & 2805 & 1144 \\
& Acklins & 0.0872 & 0.0653 & -0.3364 & 0.0986 & 1.0950 & 2893 & 1069 \\
& Yucatan & 0.0933 & 0.0747 & -0.2495 & 0.1098 & 1.1060 & 2596 & 940 \\
\hline \multirow{5}{*}{ Palaemon genome aligned } & Abaco & 0.0495 & 0.0530 & 0.0656 & 0.0604 & 1.2120 & 17 & 9 \\
& San Salvador & 0.0338 & 0.0377 & 0.1033 & 0.0314 & 1.2190 & 13 & 6 \\
& Acklins & 0.0383 & 0.0381 & -0.0054 & 0.0332 & 1.2250 & 14 & 6 \\
& Yucatan & 0.0590 & 0.0575 & -0.0256 & 0.0628 & 1.2230 & 13 & 5 \\
\hline
\end{tabular}

For each column, colors indicate similar in values for each column. $H_{O}$, observed heterozygosity; $H_{S}$, heterozygosity within populations ("genetic diversity"); $F_{I S}$, inbreeding coefficient; $N e$, effective population size bias; $\pi$, nucleotide diversity (calculated with invariant loci); $A_{m}$, polymorphic sites; $A_{p}$; private alleles. 
Table 2. Measures of genomic diversity for 47 Barbouria cubensis from for geographical populations calculated using the FSD from random unlinked single nucleotide polymorphic loci and $0 \%$ missing loci between individuals or within.

\begin{tabular}{lccccccc}
\hline \multicolumn{1}{c}{ Population } & $\boldsymbol{H}_{\boldsymbol{o}}$ & $\boldsymbol{H}_{\boldsymbol{s}}$ & $\boldsymbol{G}_{\boldsymbol{l}}$ & $\boldsymbol{\pi}$ & $\boldsymbol{A}_{\boldsymbol{v}}$ & $\boldsymbol{A}_{\boldsymbol{m}}$ & $\boldsymbol{A}_{\boldsymbol{P}}$ \\
\hline Abaco & 0.0618 & 0.0472 & -0.30932 & 0.056755 & 927 & 360 & 215 \\
San Salvador & 0.0626 & 0.0475 & -0.31789 & 0.056361 & 927 & 361 & 214 \\
Acklins & 0.0482 & 0.0333 & -0.44745 & 0.046586 & 927 & 261 & 141 \\
Yucatán & 0.0621 & 0.0463 & -0.34125 & 0.055665 & 927 & 280 & 156 \\
\hline
\end{tabular}

$H_{O}$, observed heterozygosity; $H_{S}$, mean expected heterozygosity; $\mathrm{G}_{I S}$, inbreeding coefficient; $\pi$, nucleotide diversity (calculated with invariant loci); $A v$, variant sites; $A_{m}$, polymorphic sites; $A_{p}$; private alleles. 
Table 3. Measures of genomic diversity between populations of Barbouria cubensis from for geographical populations within the Bahamas and the Yucatán Peninsula, Mexico, calculated using the FSD dataset from random unlinked single nucleotide polymorphic loci and $0 \%$ missing loci between individuals or within populations. Also, with marine geographic distances between nearest sampling sites among populations of Barbouria cubensis. Distances reported are the shortest possible direct path through water among populations sampled in this study.

\begin{tabular}{lcccr}
\hline Population-Pair & $\boldsymbol{F}_{\boldsymbol{S T}}$ & $\mathbf{G}_{\boldsymbol{S T}}$ & $\boldsymbol{\Delta}_{\mathrm{xy}}$ & Distance $(\mathrm{km})$ \\
\hline Abaco - San Salvador & 0.01958 & -0.00328 & 0.00053 & 350 \\
Abaco - Acklins & 0.01994 & -0.00363 & 0.00056 & 500 \\
San Salvador - Acklins & 0.02318 & -0.00363 & 0.00055 & 150 \\
Abaco - Yucatán & 0.02003 & -0.00321 & 0.00058 & 1200 \\
San Salvador - Yucatán & 0.02232 & -0.00345 & 0.00059 & 1400 \\
Acklins - Yucatán & 0.02334 & -0.00392 & 0.00064 & 1450 \\
\hline$F_{S T}$ biallelic genetic distance (Wright, 1969); $G_{S T,}$ multiallelic genetic diversity (Nei,
\end{tabular}
1973); $\Delta_{X Y}$, genetic divergence between populations as a function of $\pi$ (Hedrick, 2005).

\section{FIGURE CAPTIONS}

Figure 1. Workflow for generating and comparing de novo, Barbouria cubensis partial draft genome referenced and Palaemon carnicauda genome referenced assembly test datasets.

Figure 2. An example of the histograms of k-mer counting used as part of estimating genome size and scaffold contiguity; (A) before short read polishing and (B) after short read polishing. 
Figure 3. (A) fastSTRUCTURE analysis without admixture using total number of sample sites as the maximum number of clusters $(K=1-29)$. fastSTRUCTURE results are the same for the de novo and aligned test SNP data sets; (B) PCA of Barbouria cubensis de novo assembled SNPs with $95 \%$ confidence ellipse.

Figure 4. Proportions of total genetic variance contained within subpopulations; Abaco, Acklins, San Salvador (SanSal), Bahamas and The Yucatán Peninsula.

Figure 5. Inferred population structure for 47 Barbouria cubensis as estimated by the software STRUCTURE using the ancestry linkage model (bottom); inferred number of populations and populations admixture for 827 SNPs as estimated by the software ADMIXTURE (bottom); PCA of Barbouria cubensis using the final dataset of 827 SNPs (right).

Figure 6. Haplotype networks constructed using phased haplotypes from finalized SNP dataset (top), and a corresponding haplotype network map of the western Atlantic (bottom).

Figure 7. Diversity metrics (observed heterozygosity $H_{o}$, expected heterozygosity $H_{e}$, and inbreeding coefficient $G_{I S}$ ) are compared between collection localities in the Bahamas and Mexico for Barbouria cubensis (note $H_{o}$ and $H_{e}$ are on the primary y-axis and $G_{I S}$ is on the secondary y-axis). 
Figure 8. Relative migration levels between populations of Barbouria cubensis in the western Atlantic generated with the divMigrate function of diversity package in R. Manually depicted populations with $N_{m}$ values (A), Jost's D (B) and $G_{S T}$ models. The direction of arrows indicates the direction and thickness represents the magnitude of gene flow. (1) Abaco, Bahamas (2) San Salvador, Bahamas, (3) Acklins, Bahamas and (4) the Yucatán Peninsula, Mexico. 


\section{FIGURES}

Figure 1.

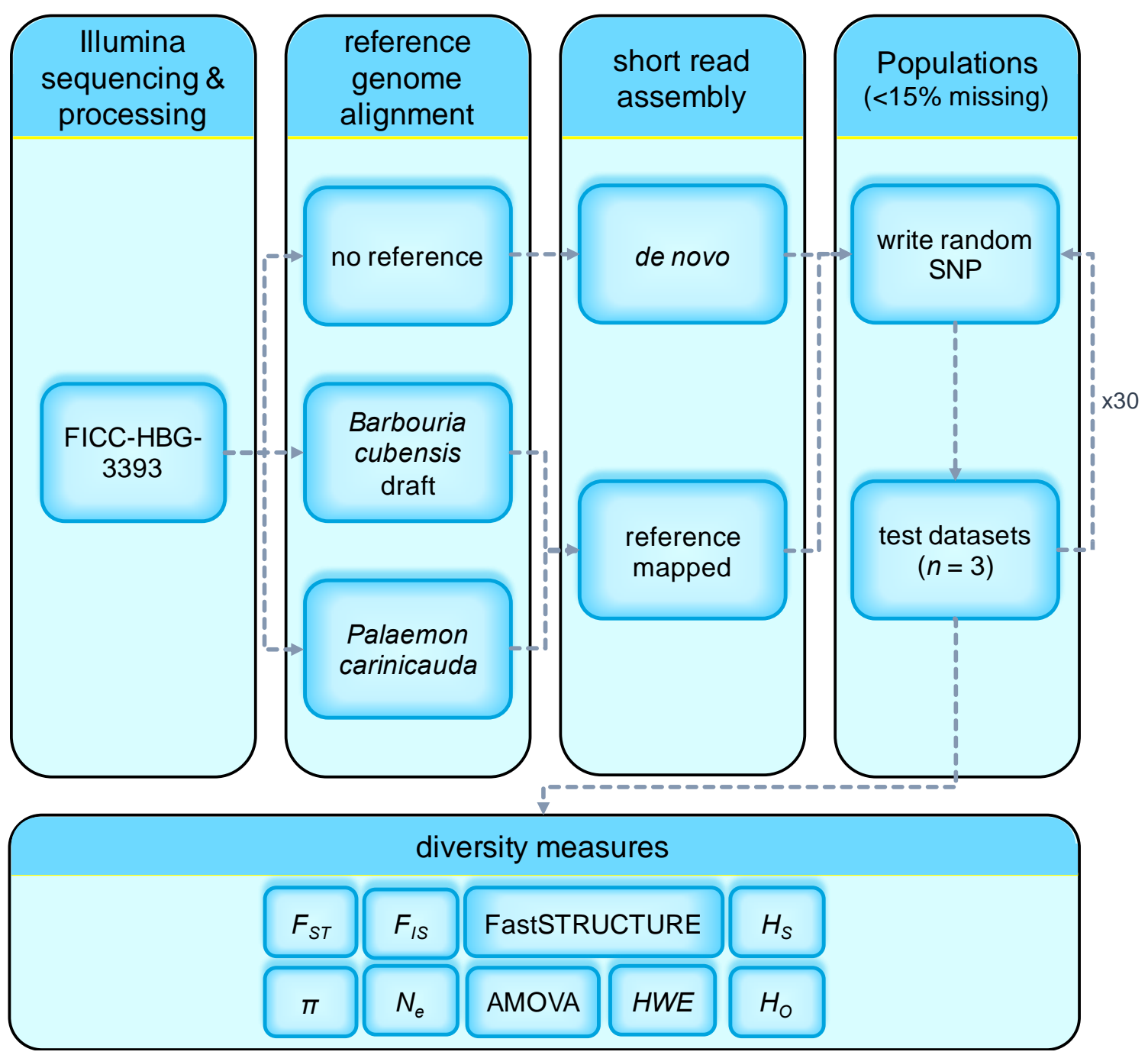


Figure 2.

A GenomeScope Profile

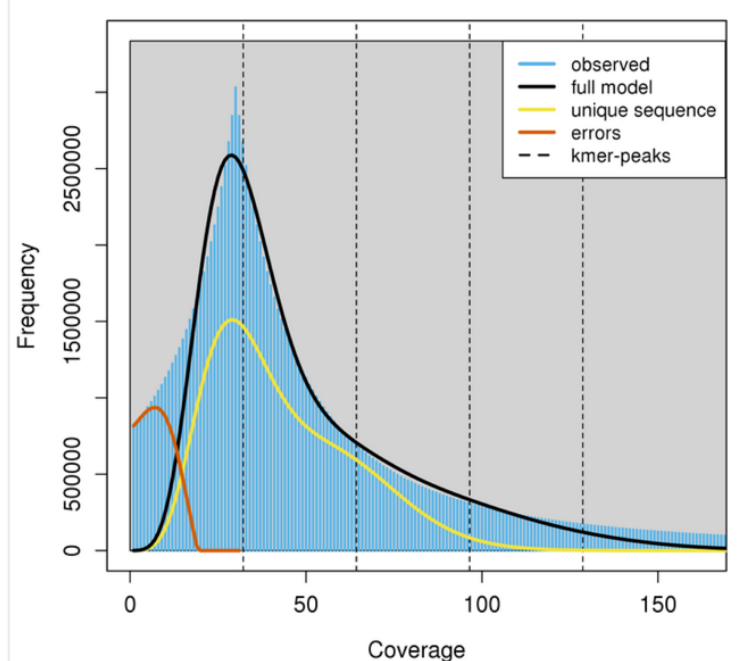

B GenomeScope Profile

B len:905,471,962bp uniq:13.2\% het:5.28\% kcov:11.3 err:0\% dup:0.274\% k:17

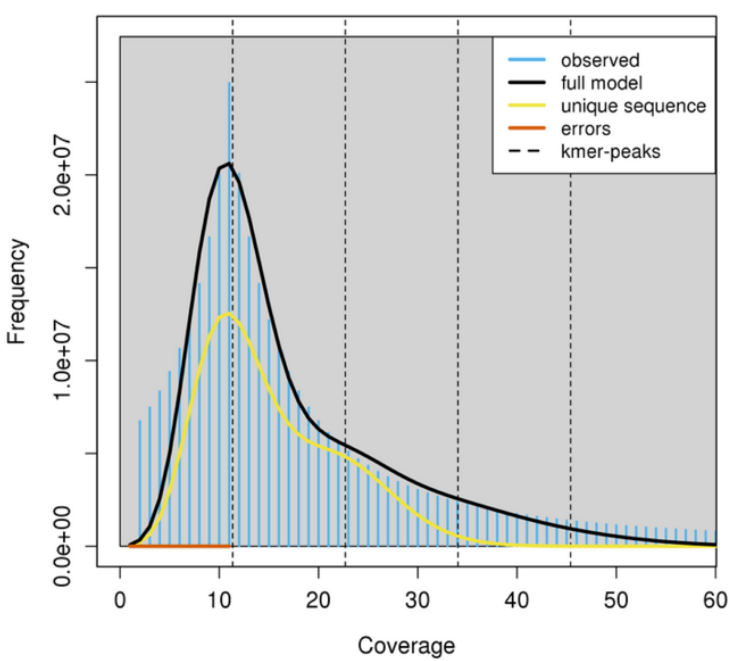

GenomeScope Profile

Ien:274,657,714bp uniq $150 \%$ tup:3.23\% k:17

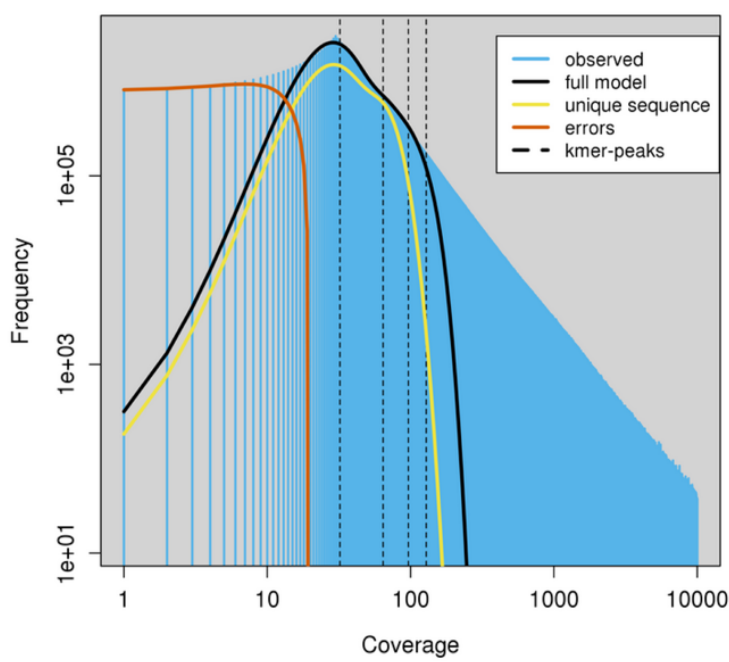

GenomeScope Profile

len:905,471,962bp uniq:13.2\% het:5.28\% kcov:11.3 err:0\% dup:0.274\% $\mathrm{k}: 17$

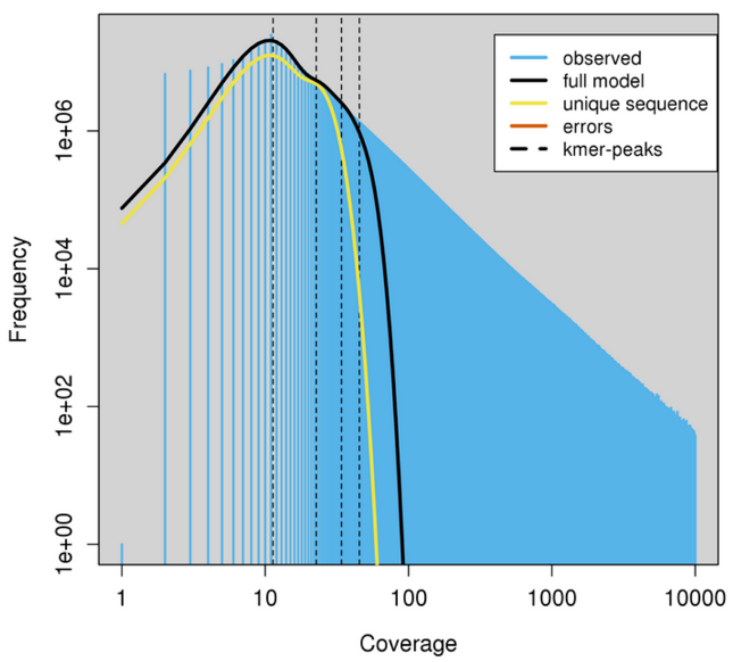


Figure 3.

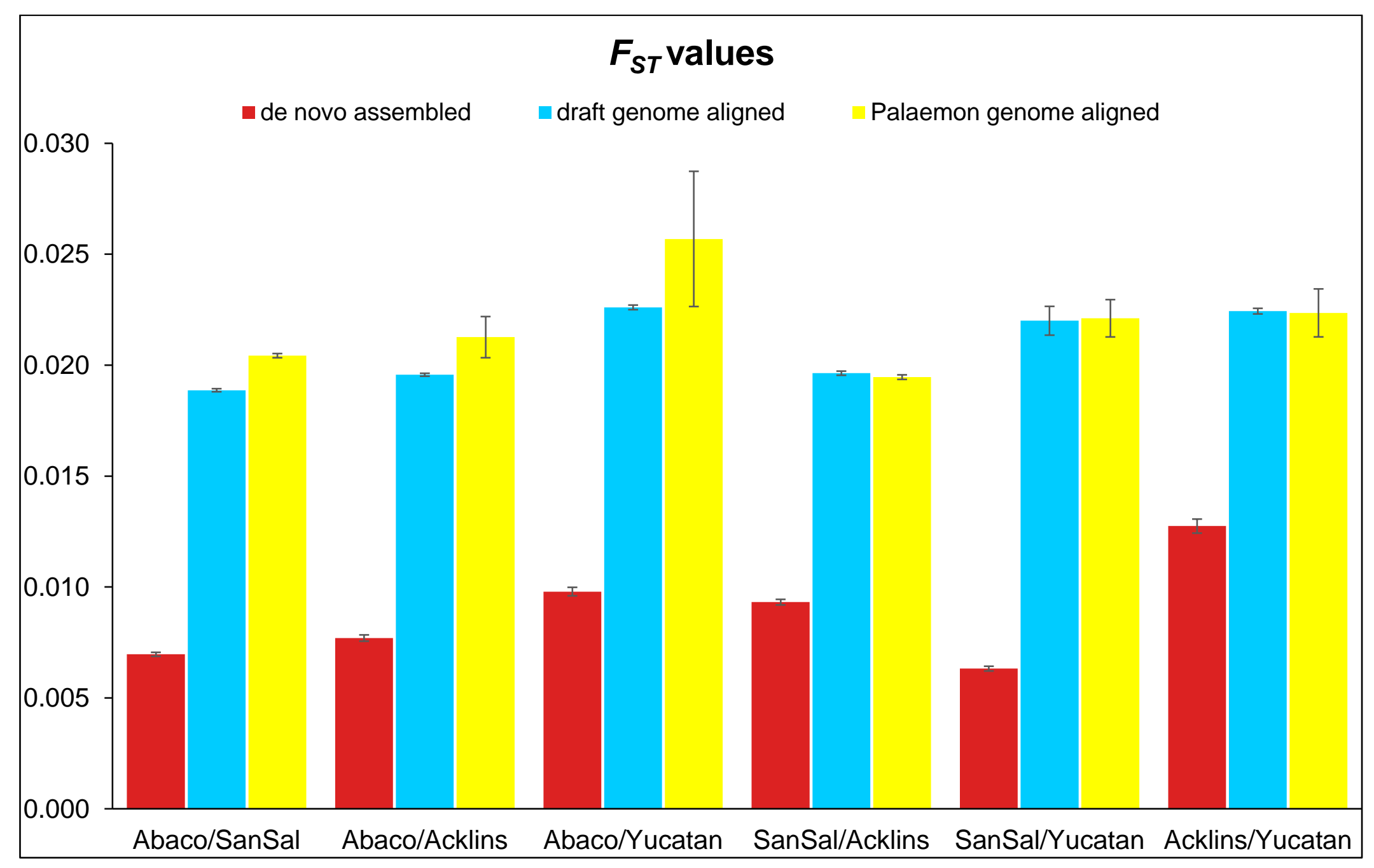


Figure 4.
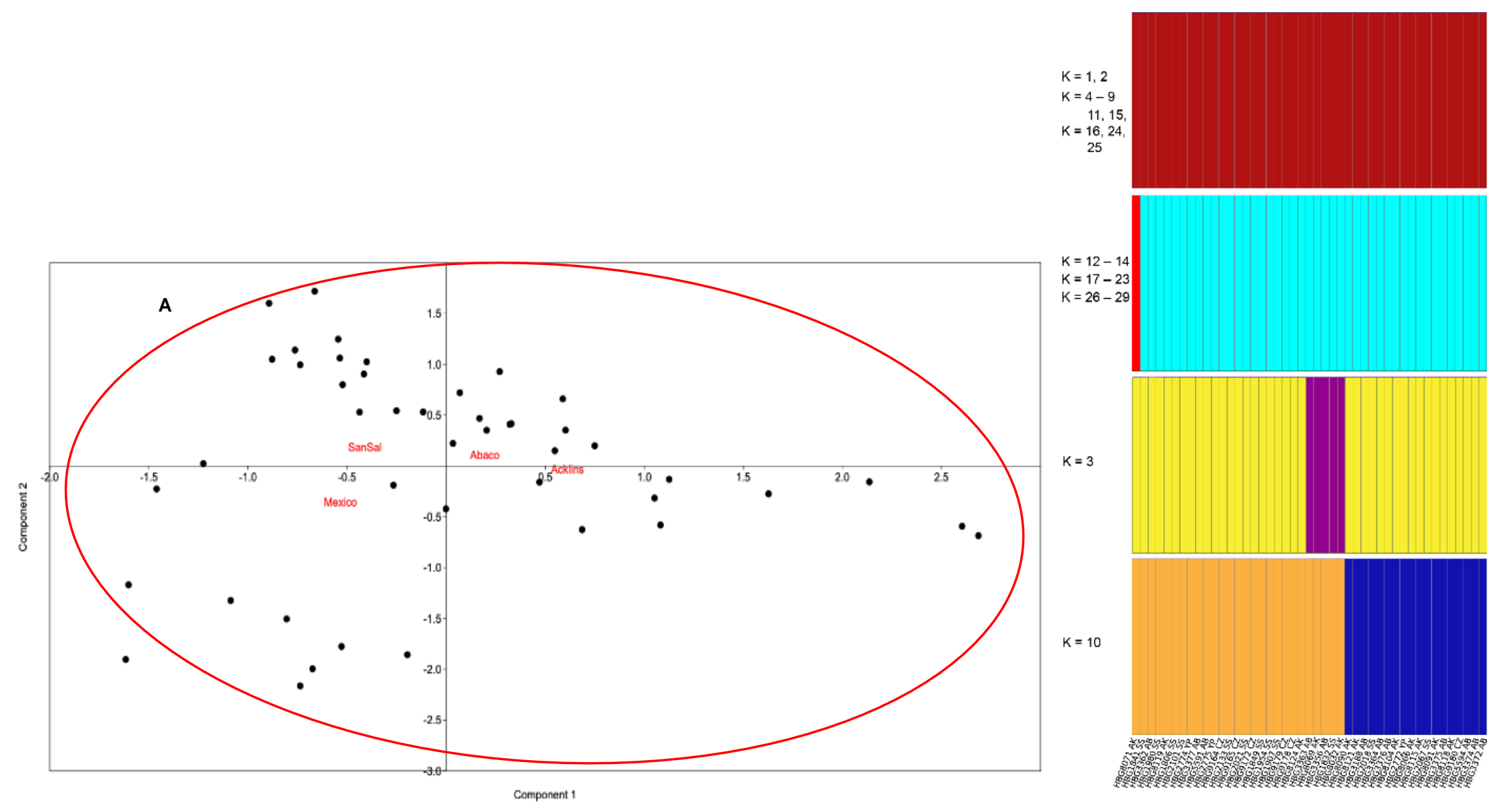
Figure 5.

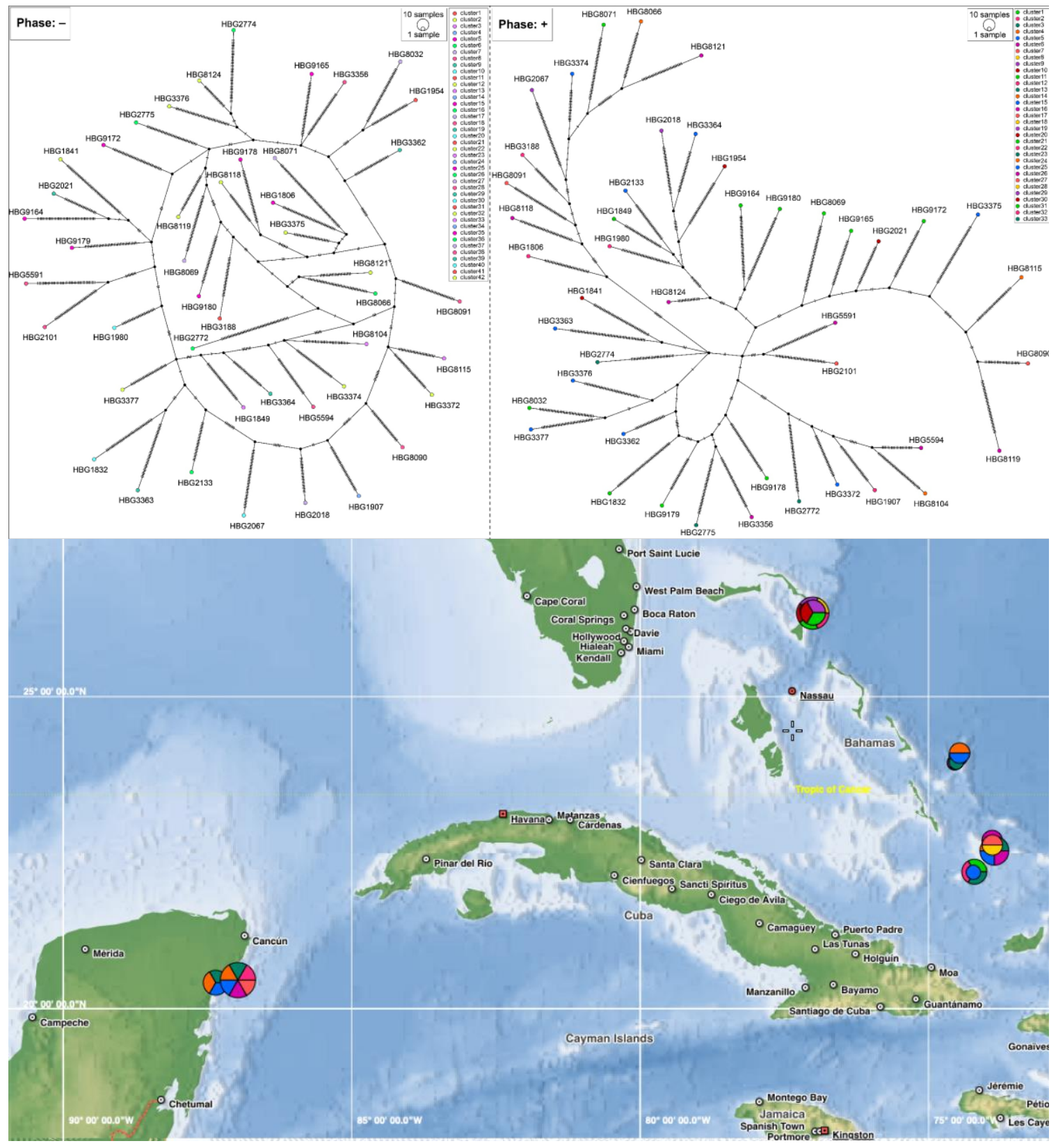


Figure 6.

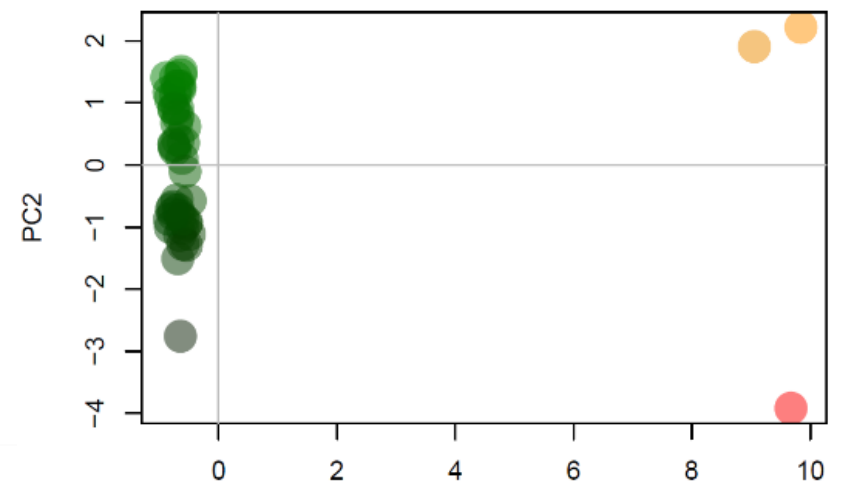

PC1
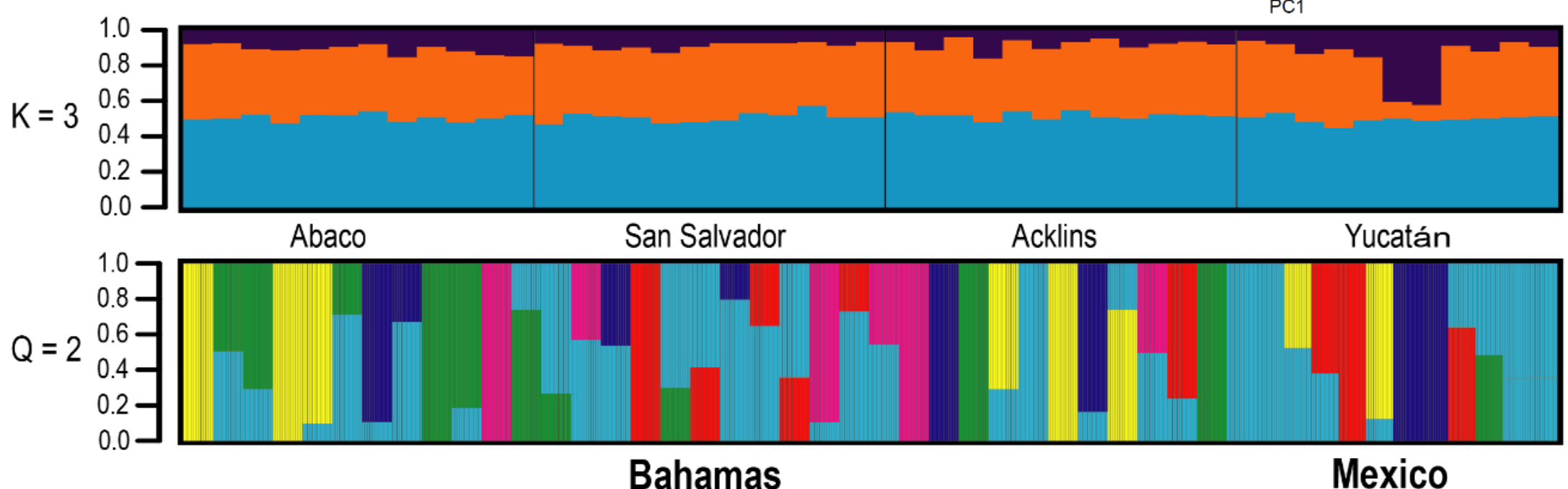
Figure 7.

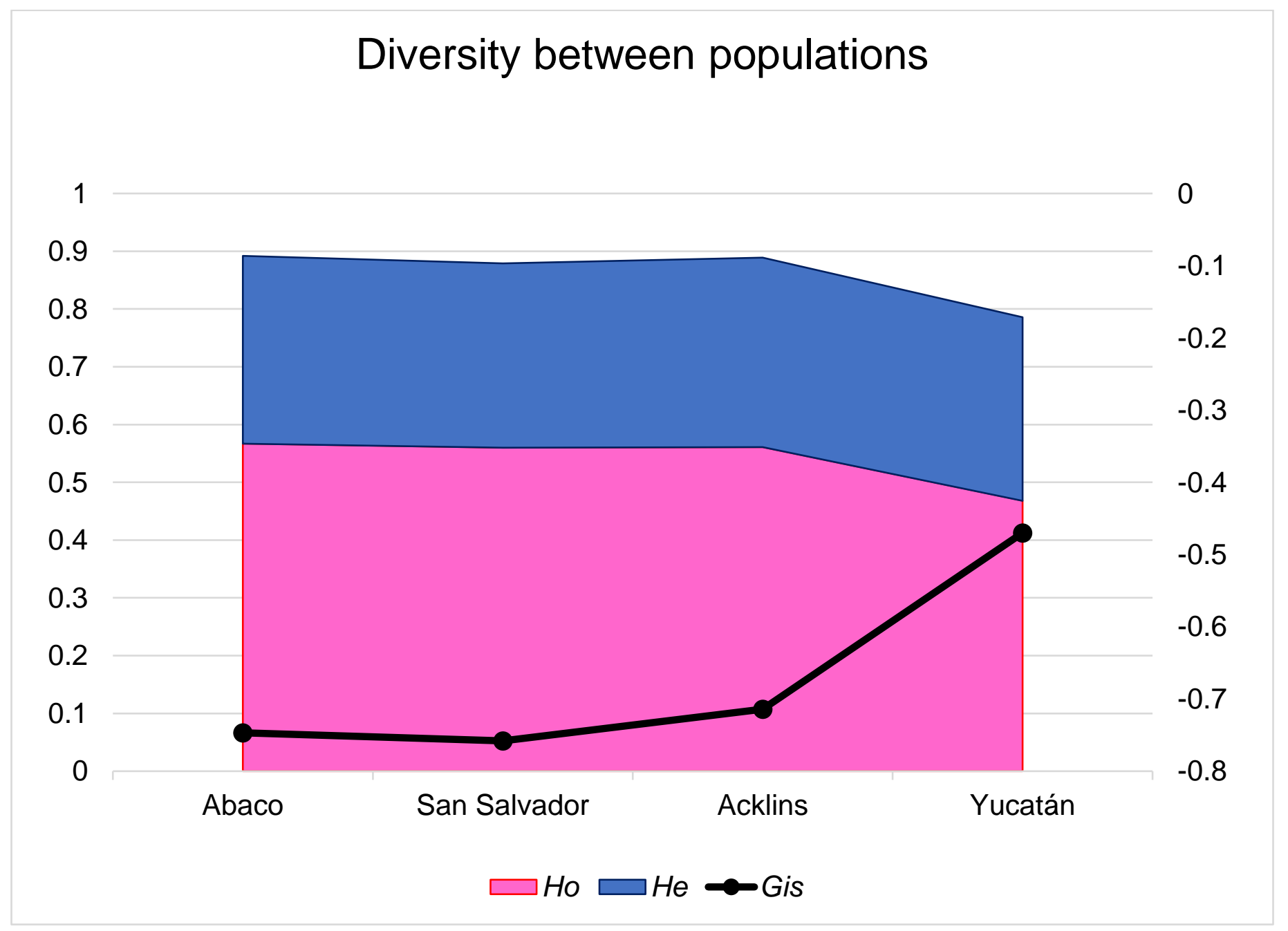


Figure 8.

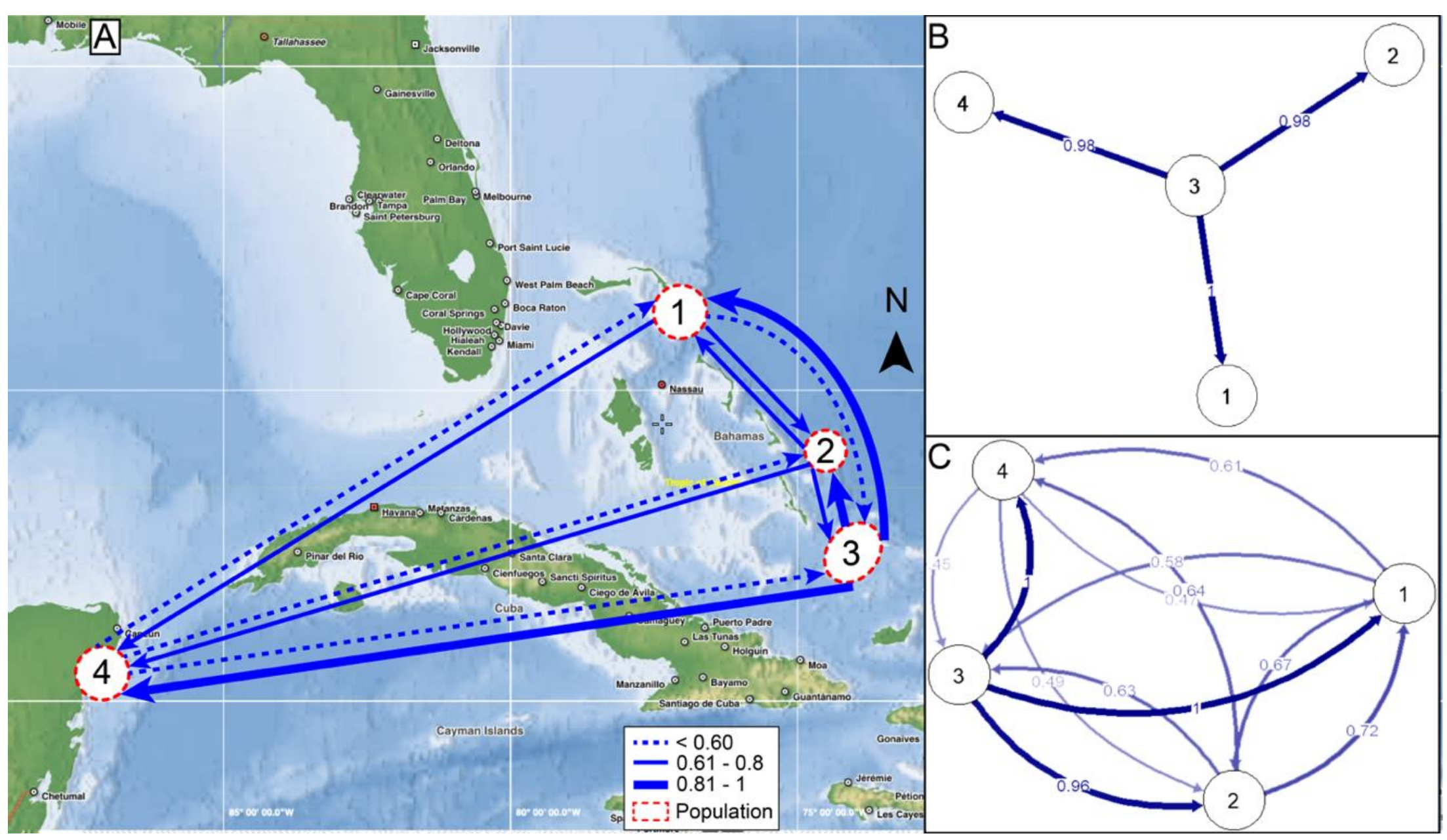




\section{APPENDICES CAPTIONS}

Appendix Table 1. Metadata for all samples included in this study, including Florida

International Crustacean Collection (FICC) museum catalog number, collection locality, collection site, collection date and GPS coordinates for the collection site. *, individual used to generate partial draft genome assembly.

\section{APPENDICES}

\section{Appendix Table 1.}

\begin{tabular}{|c|c|c|c|c|c|}
\hline \multirow{2}{*}{$\begin{array}{l}\text { FICC museum } \\
\text { catalog no. }\end{array}$} & \multicolumn{3}{|c|}{ Collection } & \multicolumn{2}{|c|}{ Coordinates } \\
\hline & Locality & Site & Date & Latitude & Longitude \\
\hline HBG3188 & Abaco, Bahamas & Dean's Cave & 11-Dec-09 & $26.35^{\circ} \mathrm{N}$ & $-77.11^{\circ} \mathrm{W}$ \\
\hline HBG3356 & Abaco, Bahamas & Lora's Pond & 31-Mar-15 & $26.31^{\circ} \mathrm{N}$ & $-77.00^{\circ} \mathrm{W}$ \\
\hline HBG3362 & Abaco, Bahamas & Lora's Pond & 31-Mar-15 & $26.32^{\circ} \mathrm{N}$ & $-77.00^{\circ} \mathrm{W}$ \\
\hline HBG3363 & Abaco, Bahamas & Dripping Stone Cave & 31-Mar-15 & $26.32^{\circ} \mathrm{N}$ & $-77.00^{\circ} \mathrm{W}$ \\
\hline HBG3364 & Abaco, Bahamas & Dripping Stone Cave & 31-Mar-15 & $26.32^{\circ} \mathrm{N}$ & $-77.00^{\circ} \mathrm{W}$ \\
\hline HBG3372 & Abaco, Bahamas & Runge's Sinkhole & 31-Mar-15 & $26.31^{\circ} \mathrm{N}$ & $-77.01^{\circ} \mathrm{W}$ \\
\hline HBG3374 & Abaco, Bahamas & Runge's Sinkhole & 31-Mar-15 & $26.31^{\circ} \mathrm{N}$ & $-77.01^{\circ} \mathrm{W}$ \\
\hline HBG3375 & Abaco, Bahamas & Runge's Sinkhole & 31-Mar-15 & $26.31^{\circ} \mathrm{N}$ & $-77.01^{\circ} \mathrm{W} \mathrm{W}$ \\
\hline HBG3376 & Abaco, Bahamas & Runge's Sinkhole & 31-Mar-15 & $26.31^{\circ} \mathrm{N}$ & $-77.01^{\circ} \mathrm{W}$ \\
\hline HBG3377 & Abaco, Bahamas & Runge's Sinkhole & 31-Mar-15 & $26.31^{\circ} \mathrm{N}$ & $-77.01^{\circ} \mathrm{W}$ \\
\hline HBG5591 & Abaco, Bahamas & Lora's Pond & 17-Mar-16 & $26.31^{\circ} \mathrm{N}$ & $-77.00^{\circ} \mathrm{W}$ \\
\hline HBG5594 & Abaco, Bahamas & Lora's Pond & 17-Mar-16 & $26.31^{\circ} \mathrm{N}$ & $-77.00^{\circ} \mathrm{W}$ \\
\hline HBG1806 & San Salvador, Bahamas & Oyster Pond & 29-Jun-12 & $24.11^{\circ} \mathrm{N}$ & $-74.46^{\circ} \mathrm{W}$ \\
\hline HBG1832 & San Salvador, Bahamas & Watling's Blue Hole & 29-Jun-12 & $23.95 \div \mathrm{N}$ & $-74.55^{\circ} \mathrm{W}$ \\
\hline HBG1841 & San Salvador, Bahamas & Plantation Pond & 29-Jun-12 & $24.04^{\circ} \mathrm{N}$ & $-74.45^{\circ} \mathrm{W}$ \\
\hline HBG1849 & San Salvador, Bahamas & Mermaid Pond & 29-Jun-12 & $23.97^{\circ} \mathrm{N}$ & $-74.52^{\circ} \mathrm{W}$ \\
\hline HBG1907 & San Salvador, Bahamas & Pain Pond & 17-Jun-13 & $24.11^{\circ} \mathrm{N}$ & $-74.46^{\circ} \mathrm{W}$ \\
\hline HBG1954 & San Salvador, Bahamas & Little Lake & 29-Jun-13 & $24.05^{\circ} \mathrm{N}$ & $-74.51^{\circ} \mathrm{W}$ \\
\hline HBG1980 & San Salvador, Bahamas & Dunk City Pond & 03-Jun-14 & $23.96 \div \mathrm{N}$ & $-74.53^{\circ} \mathrm{W}$ \\
\hline HBG2018 & San Salvador, Bahamas & Lighthouse Cave & 08-Jun-14 & $24.10^{\circ} \mathrm{N}$ & $-74.45^{\circ} \mathrm{W}$ \\
\hline HBG2021 & San Salvador, Bahamas & Major's Cave & 11-Jun-14 & $24.07^{\circ} \mathrm{N}$ & $-74.51^{\circ} \mathrm{W}$ \\
\hline HBG2067 & San Salvador, Bahamas & Blue Hole \#2 & 16-Jun-14 & 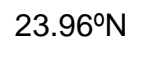 & $-74.55^{\circ} \mathrm{W}$ \\
\hline HBG2101 & San Salvador, Bahamas & Big Rob Pond & 18-Jun-14 & $24.03^{\circ} \mathrm{N}$ & $-74.46^{\circ} \mathrm{W}$ \\
\hline HBG2133 & San Salvador, Bahamas & William's Pond & 15-Jun-14 & $24.02^{\circ} \mathrm{N}$ & $-74.52^{\circ} \mathrm{W}$ \\
\hline HBG8032 & Acklins, Bahamas & Nibbler's Cave & 19-Jul-17 & $22.22^{\circ} \mathrm{N}$ & $-74.20^{\circ} \mathrm{W}$ \\
\hline HBG8066 & Acklins, Bahamas & Flamingo Pond & 20-Jul-17 & $22.21^{\circ} \mathrm{N}$ & $-74.22^{\circ} \mathrm{W}$ \\
\hline
\end{tabular}




\section{Appendix Table 1. Con't.}

\begin{tabular}{|c|c|c|c|c|c|}
\hline \multirow{2}{*}{$\begin{array}{l}\text { FICC museum } \\
\text { catalog no. }\end{array}$} & \multicolumn{3}{|c|}{ Collection } & \multicolumn{2}{|c|}{ Coordinates } \\
\hline & Locality & Site & Date & Latitude & Longitude \\
\hline HBG8069 & Acklins, Bahamas & Nibbler's Cave & 19-Jul-17 & $22.22^{\circ} \mathrm{N}$ & $-74.20^{\circ} \mathrm{W}$ \\
\hline HBG8071 & Acklins, Bahamas & Nibbler's Cave & 19-Jul-17 & $22.22^{\circ} \mathrm{N}$ & $-74.20^{\circ} \mathrm{W}$ \\
\hline HBG8090 & Acklins, Bahamas & Pinefield Pond & 23-Jul-17 & $22.65^{\circ} \mathrm{N}$ & $-73.89^{\circ} \mathrm{W}$ \\
\hline HBG8091 & Acklins, Bahamas & Pinefield Pond & 23-Jul-17 & $22.65 \% \mathrm{~N}$ & $-73.89^{\circ} \mathrm{W}$ \\
\hline HBG8104 & Acklins, Bahamas & Red Lantern Cave & 23-Jul-17 & $22.72^{\circ} \mathrm{N}$ & $-73.89^{\circ} \mathrm{W}$ \\
\hline HBG8115 & Acklins, Bahamas & Red Lantern Cave & 23-Jul-17 & $22.72^{\circ} \mathrm{N}$ & $-73.89^{\circ} \mathrm{W}$ \\
\hline HBG8118 & Acklins, Bahamas & Big Pond & 26-Jul-17 & $22.55^{\circ} \mathrm{N}$ & $-73.86^{\circ} \mathrm{W}$ \\
\hline HBG8119 & Acklins, Bahamas & Big Pond & 26-Jul-17 & $22.55^{\circ} \mathrm{N}$ & $-73.86^{\circ} \mathrm{W}$ \\
\hline HBG8121 & Acklins, Bahamas & Big Pond & 26-Jul-17 & $22.55^{\circ} \mathrm{N}$ & $-73.86^{\circ} \mathrm{W}$ \\
\hline HBG8124 & Acklins, Bahamas & Big Pond & 26-Jul-17 & $22.55^{\circ} \mathrm{N}$ & $-73.86^{\circ} \mathrm{W}$ \\
\hline HBG2772 & Akumal, Q. Roo, Mexico & Cenote 21 Pasos & 01-Jan-03 & $20.42^{\circ} \mathrm{N}$ & $-87.36^{\circ} \mathrm{W}$ \\
\hline HBG2774 & Akumal, Q. Roo, Mexico & Cenote 21 Pasos & 01-Jan-03 & $20.42^{\circ} \mathrm{N}$ & 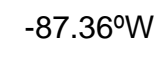 \\
\hline HBG2775 & Akumal, Q. Roo, Mexico & Cenote 21 Pasos & 01-Jan-03 & $20.42^{\circ} \mathrm{N}$ & $-87.36^{\circ} \mathrm{W}$ \\
\hline HBG9162 & Cozumel, Mexico & Cenote Tres Potrillos & 29-Oct-11 & $20.46^{\circ} \mathrm{N}$ & $-86.97^{\circ} \mathrm{W}$ \\
\hline HBG9164 & Cozumel, Mexico & Cenote Tres Potrillos & 29-Oct-11 & $20.46^{\circ} \mathrm{N}$ & $-86.97^{\circ} \mathrm{W}$ \\
\hline HBG9165 & Cozumel, Mexico & Cenote Tres Potrillos & 29-Oct-11 & $20.46 \div \mathrm{N}$ & $-86.97^{\circ} \mathrm{W}$ \\
\hline HBG9169 & Cozumel, Mexico & Cenote Tres Potrillos & 29-Oct-11 & $20.46^{\circ} \mathrm{N}$ & $-86.97^{\circ} \mathrm{W}$ \\
\hline HBG9172 & Cozumel, Mexico & Cenote Tres Potrillos & $29-$ Oct-11 & $20.46^{\circ} \mathrm{N}$ & $-86.97^{\circ} \mathrm{W}$ \\
\hline HBG9178 & Cozumel, Mexico & Cenote Tres Potrillos & 29-Oct-11 & $20.46^{\circ} \mathrm{N}$ & $-86.97^{\circ} \mathrm{W}$ \\
\hline HBG9179 & Cozumel, Mexico & Cenote Tres Potrillos & 29-Oct-11 & $20.46^{\circ} \mathrm{N}$ & $-86.97^{\circ} \mathrm{W}$ \\
\hline HBG9180 & Cozumel, Mexico & Cenote Tres Potrillos & 29-Oct-11 & $20.46^{\circ} \mathrm{N}$ & $-86.97^{\circ} \mathrm{W}$ \\
\hline *HBG3393 & San Salvador, Bahamas & William's Pond & 26-Jun-15 & $22.22 \div \mathrm{N}$ & $-74.20^{\circ} \mathrm{W}$ \\
\hline
\end{tabular}




\section{CHAPTER VI}

\section{CONCLUSTIONS AND FUTURE DIRECTIONS}


The series of works that is presented here were completed with the goal of increasing our understanding of crustacean evolution and ecology from multiple directions. Starting with a taxonomic study of the presence of extensive morphological variation, referred to as phenotypic hypervariation (PhyV), these results far exceed all previous records for any anchialine crustacean. Molecular barcoding was used to confirm the identity of Barbouria cubensis exhibiting high PhyV and to determine if PhyV is the result of cryptic speciation. This is followed with records of geographic range extensions for three anchialine crustaceans (Barbouria cubensis, Parhippolyte sterreri and Macrobrachium lucifugum), and reporting on observations of their behavior during field collection and the behavior of $B$. cubensis in a laboratory setting over course of two years. During the process of genetic identification of $B$. cubensis inaccuracies in the molecular record for species from the family Barbouriidae were uncovered. To remedy the errors in barbouriid genetics an in-depth phylogenetic study of Barbouriidae was conducted using traditional molecular methods. In chapter $\mathrm{V}$ a population genomic approach is used to test the isolation paradigm of anchialine systems, shining further light on the source of Phy V and demonstrating the value a draft genome can add to genomic studies. These studies emphasize the importance of using variety approaches when studying evolutionary processes and echo a theme of needing improved conservation of anchialine systems. In documenting phenotypic hypervariation (PhyV) and molecular barcoding of Barbouria cubensis from Abaco, Eleuthera and San Salvador, Bahamas, no geographic distribution pattern or cryptic diversity is detected. Phenotypic hypervariation was found to be present in at least one morphologically informative character in approximately $90 \%$ of specimens examined $(n=463)$. Phylogenetic analysis of the $16 \mathrm{~S}$ and COI 
mitochondrial gene regions identified all specimens $(n=70$ included in publication; $n \approx$ 130 not included publication) as $B$. cubensis. Genetic diversity is found to be very low among B. cubensis $(\mathrm{n}=70)$, suggesting high PhyV may be the result of inbreeding. The lack of geographic distribution pattern in PhyV and the lack of genetic diversity across Abaco, Eleuthera and San Salvador, Bahamas suggests that populations of B. cubensis could be highly connected. Janicea antiguensis was also found to be nested within Parhippolyte in the phylogenetic analyses of $16 \mathrm{~S}$ and COI, indicating a possible mistake in the species identities of GenBank sequences or a need to revisit the classification of the family Barbouriidae.

As part field work on Acklins Island, Bahamas collecting material to revisit the classification of Barbouriidae a geographic range extension was discovered for Barbouria cubensis, Parhippolyte sterreri and Macrobrachium lucifugum. Observations on the Behavior of the species during collection was reported. Observations on the behavior of B. cubensis was also reported from over two years in a laboratory setting as part of an attempted life history study. Barbouria cubensis was found to have large white and small red chromatophores that provide the capability of rapidly changing color in response to light and mimicking the color pattern of Parhippolyte sterreri. We also found individuals of $B$. cubensis housed separately exhibit different behavior than those housed in pairs. We conclude that it is important to report even minor range extensions, especially in threatened anchialine habitats and for critically endangered species.

In chapter IV, classification of the family Barbouriidae was examined using both morphological and molecular evidence from two mitochondrial and five nuclear gene regions. Several mistakes in the species identity of GenBank sequences were uncovered 
and corrected. Phylogenetic analysis revealed that Barbouria yanezi is a synonym for Barbouria cubensis. Based on molecular and morphological evidence we found that Janicea is junior synonym for Parhippolyte and erected two new subfamilies (Barbouriinae and Calliasmatinae). An updated identification key was provided and provide a synapomorphy for the subfamily Barbouriinae. We found that Barbouriidae originated from a shallow water reef dwelling species from the Atlantic and gained, then lost troglomorphic adaptations. Our results also suggest that Calliasmatinae may need to be elevated to the family level and that Ligur likely does not belong within Lysmata. We concluded that the study was intended to provide insight into the evolutionary history of Barbouriidae and not fully resolve the classification of Barbouriidae or Ligur.

A population genomic study was conducted testing the isolation paradigm of anchialine systems to better understand how anchialine communities are connected and to further investigate the source of high PhyV in B. cubensis. As part of the population study we found that a partial draft genome assembled from short and long genomic reads greatly improves the accuracy and utility of next generation sequencing for little extra cost $(\leqq \$ 1000)$. These findings are especially relevant for studies of critically endangered species or species with large genomes, and in studies with limited funding. Testing the "islands within islands" and "spelean corridor" hypotheses lead the proposal of a new "anchialine isolation by dispersal" hypothesis. We found that B. cubensis represents a single highly connected population with very low genetic diversity in the tropical western Atlantic and likely has strong reproductive dispersal capabilities. This suggests that PhyV is the result of an increased susceptibility environmental disturbances and a possible accumulation of deleterious alleles as a consequence of their ability to exchange genetic 
material of large geographic distances. We also discussed the need for improved conservation of anchialine systems, because of their rapid alteration or destruction by anthropogenic activity, they are home to numerous endemic species, and effects on a single seemly disjointed pond may have broad ranging consequences.

The sixth mass extinction that is a blight of the Anthropocene stands to claim numerous anchialine species. The study of a broad range of evolutionary and ecological questions using traditional and next-generation tools stands to aid in the fight to stem the global biodiversity crisis. We find across all life, species have an astonishing ability to recover following disturbances, and establishing a baseline helps to identify when additional protection is necessary to aid in their recovery. By investigating the population dynamics and structure of species with strong dispersal mechanisms we can more easily identify threats across seemingly disjointed systems. Protecting biodiversity should be our highest priority as new health threats emerge and we become more and more reliant on the environment for sources to combat these threats. 
VITA

ROBERT E. DITTER

2002-2009

B.S., Business Administration

University of Missouri

Columbia, Missouri

2010-2013

B.S. Marine Science; Minor: Biology

Graduate Cum Laude

Florida Gulf Coast University

Fort Myers, Florida

2014-2020

Doctoral Candidate

Florida International University

Miami, Florida

2014-2019

Graduate Teaching Assistant

Florida International University

Miami, Florida

2020

Dissertation Year Fellow

Florida International University

Miami, Florida

\section{PUBLICATIONS AND PRESENTATIONS}

Ditter, R.E., L.M. Mejia-Ortiz and H.D. Bracken-Grissom. 2020. Anchialine Adjustments: an updated phylogeny and classification for the family Barbouriidae Christoffersen, 1987 (Decapoda: Caridea). Journal of Crustacean Biology, In Press, 1-11. doi:10.1093/jcbiol/ruaa037.

Ditter, R.E. and H.D. Bracken-Grissom. Anchialine Adjustments: an updated classification for the family Barbouriidae. Florida International University Biology Research Symposium (Feb. 2020). Awarded: Best Oral Presentation.

Ditter, R.E., A.P. Snyder, S.E. Schulman and H.D. Bracken-Grissom. 2019. Notes on the behavior and first records of three enigmatic anchialine shrimps (Decapoda: Caridea: Barbouriidae) in the Bahamas. Journal of Crustacean Biology, 39(6): 684-688.

Ditter, R.E., R.B. Erdman, A.M. Goebel and H.D. Bracken-Grissom. 2019. Widespread phenotypic hypervariation in the enigmatic anchialine shrimp Barbouria cubensis (Decapoda: Barbouriidae). Zootaxa, 4648(1): 001-026.

Ditter, R.E. and H.D. Bracken-Grissom. The presence of phenotypic hypervariation and cryptic diversity in cave shrimp (Decapoda: Barbouria cubensis) across the Bahamas. Florida International University Biology Research Symposium (Feb. 2018). 
Ditter, R.E., R.B. Erdman, A.M. Goebel and H.D. Bracken-Grissom. Phenotypic hyper-variation, genetic species identification and population connectivity of enigmatic cave shrimp from San Salvador Island, Bahamas. Florida International University Biology Research Symposium (Feb. 2016).

Ditter, R.E. The rule breaking shrimp, how null relates tempt poor research practices. Invited Speaker. Science Fridays Organization, Florida International University (March 2016).

Ditter, R.E., R.B. Erdman and A.M. Goebel. (2015). Unexpected phenotypic variation among cryptic caridean shrimp: Constraints with traditional morphology in specimens from San Salvador, Bahamas. Proceedings of the 15th Symposium on the Natural History of The Bahamas, 63-72.

Ditter, R.E., R.B. Erdman, A.M. Goebel and H.D. Bracken-Grissom. Species identification and population connectivity of enigmatic cave shrimp. 1st Joint Natural History and Geology Conference. Gerace Research Centre. San Salvador, Bahamas (June 2015).

Vitali, J.D., Zekanoski, M., Squiccimara, L.J., Ditter, R.E., Ingalsbe, T.A., Fitzpatrick, M.G., Sabourin, D.J., Jones, K.R., Hunt, M.A., and Savarese, M. (2013). Recognition of backbarrier island hurricane-generated paleotempestites: an actualistic taphonomic study of nearshore, overwash, and lagoon death assemblages. Geological Society of America Abstracts with Programs 45(2):65.

Ditter, R.E., R.B. Erdman, and A.M. Goebel. Development of a nondestructive tissue sampling method for Decapod Crustaceans: A case study with the pink Shrimp Farfantepenaeus duorarum. 15th Symposium on the Natural History of the Bahamas. Gerace Research Centre, San Salvador, Bahamas (June 2013) and FGCU Research Day Florida Gulf Coast University, Fort Myers, Florida, USA (April 2013).

Ditter, R.E., R.B. Erdman, and A.M. Goebel. Unexpected phenotypic variation among cryptic caridean shrimp from San Salvador Island, Bahamas: Constraints with traditional morphology supports the use of molecular tools in population studies. 15th Symposium on the Natural History of the Bahamas, Gerace Research Centre, San Salvador, Bahamas (June 2013) and FGCU Research Day, Florida Gulf Coast University, Fort Myers, Florida, USA (April 2013). 